MONOGRAPHS

\title{
IN GERMAN
}

HISTORY

VOLUME 26
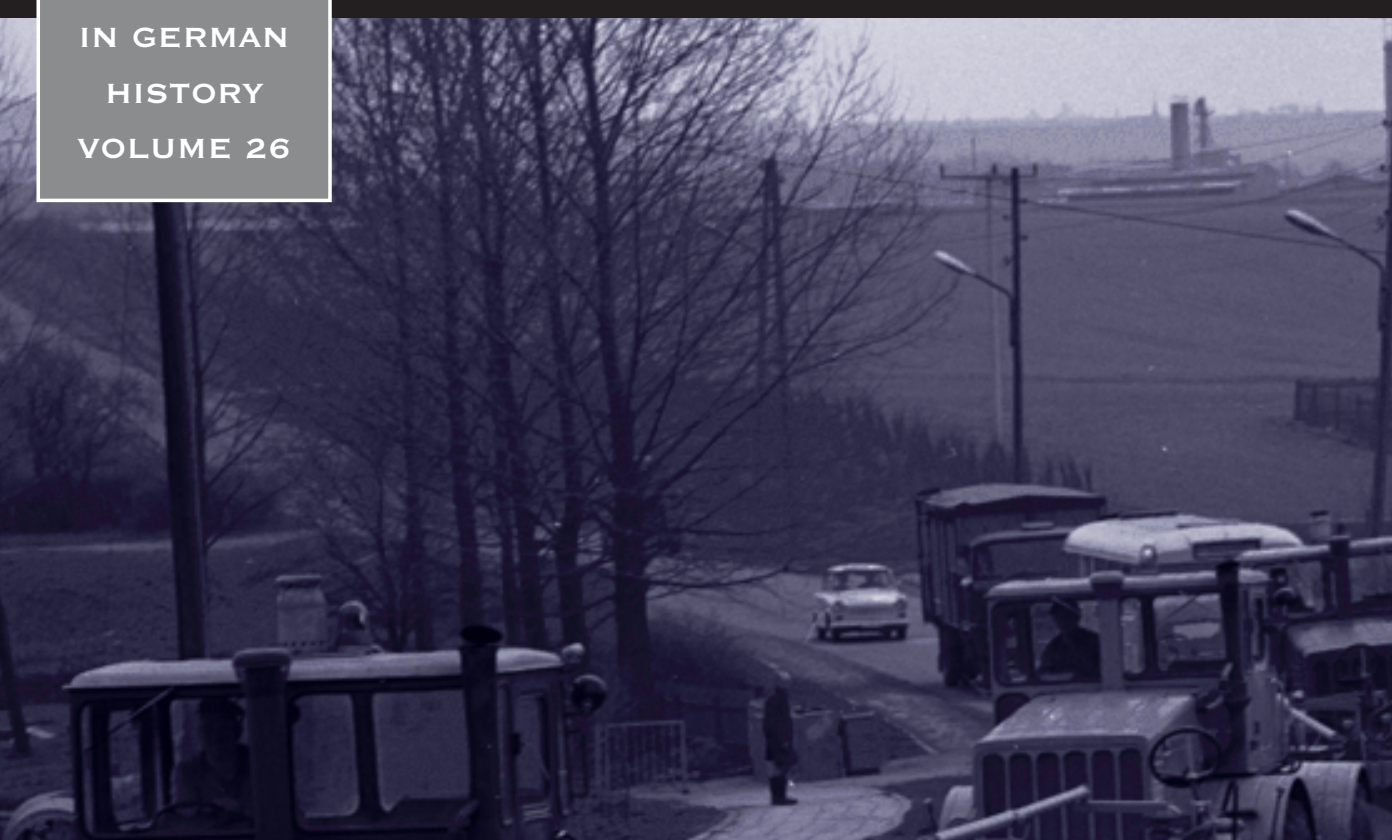

[i] $-$
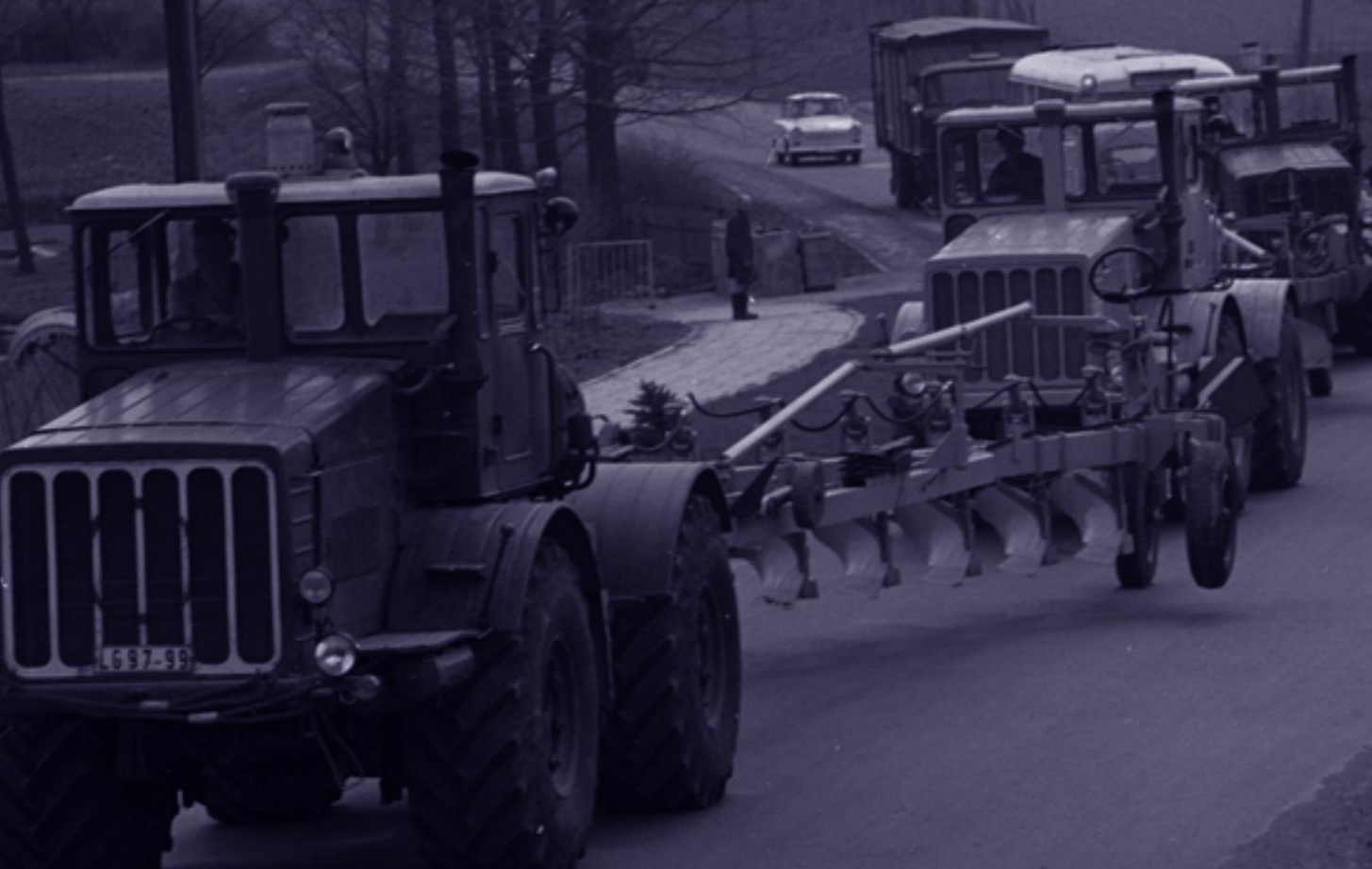

r

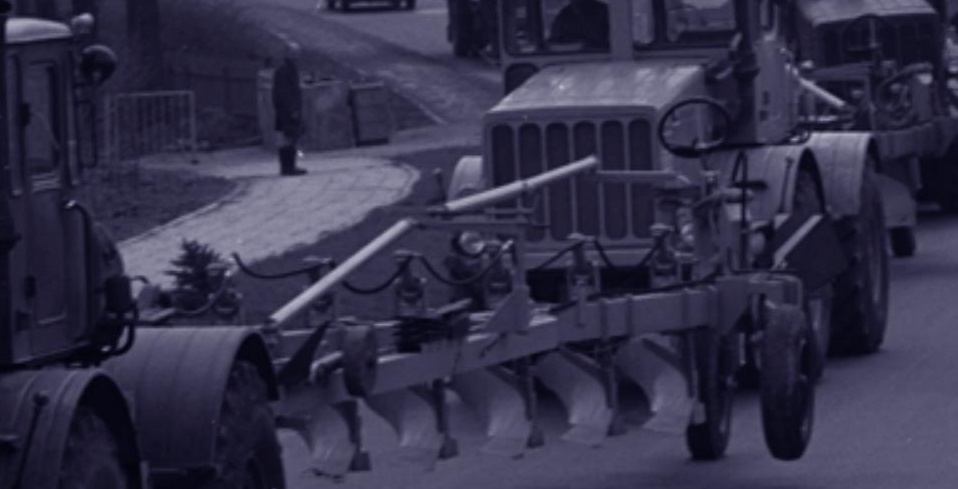

AFTER THE

'SOCIALIST SPRING'

COLLECTIVISATION AND ECONOMIC TRANSFORMATION IN THE GDR

GEORGE LAST 



\section{Monographs in German History}

Volume 1

Osthandel and Ostpolitik: German Foreign Trade Policies

in Eastern Europe from Bismarck to Adenauer

Mark Spaulding

Volume 2

A Question of Priorities: Democratic Reform and

Economic Recovery in Postwar Germany

Rebecca Boehling

Volume 3

From Recovery to Catastrophe: Municipal Stabilization and Political Crisis in Weimar Germany

Ben Lieberman

Volume 4

Nazism in Central Germany: The Brownshirts in 'Red'

Saxony

Christian W. Szejnmann

Volume 5

Citizens and Aliens: Foreigners and the Law in Britain and the German States, 1789-1870

Andreas Fahrmeir

Volume 6

Poems in Steel: National Socialism and the Politics of

Inventing from Weimar to Bonn

Kees Gispen

Volume 7

"Aryanisation" in Hamburg

Frank Bajohr

Volume 8

The Politics of Education: Teachers and School Reform in Weimar Germany

Marjorie Lamberti

Volume 9

The Ambivalent Alliance: Konrad Adenauer, the CDU/

CSU, and the West, 1949-1966

Ronald J. Granieri

\section{Volume 10}

The Price of Exclusion: Ethnicity, National Identity, and the Decline of German Liberalism, 1898-1933

E. Kurlander

\section{Volume 11}

Recasting West German Elites: Higher Civil Servants,

Business Leaders, and Physicians in Hesse between

Nazism and Democracy, 1945-1955

Michael R. Hayse

Volume 12

The Creation of the Modern German Army: General Walther Reinhardt and the Weimar Republic, 1914-1930 William Mulligan

Volume 13

The Crisis of the German Left: The PDS, Stalinism and the Global Economy

Peter Thompson

\section{Volume 14}

"Conservative Revolutionaries": Protestant and Catholic Churches in Germany After Radical Political Change in the 1990s

Barbara Thériault

\section{Volume 15}

Modernizing Bavaria: The Politics of Franz Josef Strauss and the CSU, 1949-1969

Mark Milosch
Volume 16

Sex,Thugs and Rock ' $N$ ' Roll. Teenage Rebels in

Cold-War East Germany

Mark Fenemore

Volume 17

Cultures of Abortion in Weimar Germany

Cornelie Usborne

Volume 18

Selling the Economic Miracle: Economic Reconstruction and Politics In West Germany, 1949-1957

Mark E. Spicka

Volume 19

Between Tradition and Modernity: Aby Warburg and Art in Hamburg's Public Realm 1896-1918

Mark A. Russell

Volume 20

A Single Communal Faith? The German Right from

Conservatism to National Socialism

Thomas Rohkrämer

Volume 21

Environmental Organizations in Modern Germany: Hardy Survivors in the Twentieth Century and Beyond William T. Markham

Volume 22

Crime Stories: Criminalistic Fantasy and the Culture of Crisis in Weimar Germany

Todd Herzog

Volume 23

Liberal Imperialism in Germany

Expansionism and Nationalism, 1848-1884

Matthew P. Fitzpatrick

Volume 24

Bringing Culture to the Masses

Control, Compromise and Participation in the GDR

Esther von Richthofen

Volume 25

Banned in Berlin: Literary Censorship in Imperial

Germany, 1871-1918

Gary D. Stark

Volume 26

After the 'Socialist Spring': Collectivisation and

Economic Transformation in the GDR

George Last

Volume 27

Learning Democracy: Education Reform in West

Germany, 1945-1965

Brian M. Puaca

Volume 28

Weimar Radicals: Nazis and Communists between

Authenticity and Performance

Timothy S. Brown

Volume 29

The Political Economy of Germany under Chancellors Köhl and Schröder: Decline of the German Model? Jeremy Leaman

Volume 30

The Surplus Woman

Unmarried in Imperial Germany, 1871-1918

Catherine L. Dollard 


\section{After the 'Socialist Spring'}

Collectivisation and Economic Transformation in the GDR

\section{George Last}

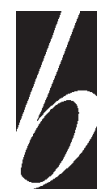

Berghabn Books

New York • Oxford 


\section{After the 'Socialist Spring'}


First published in 2009 by

\section{Berghahn Books}

www.berghahnbooks.com

(C) 2009, 2019 George Last

Open access edition published in 2019

All rights reserved. Except for the quotation of short passages for the purposes of criticism and review, no part of this book may be reproduced in any form or by any means, electronic or mechanical, including photocopying, recording, or any information storage and retrieval system now known or to be invented, without written permission of the publisher.

\section{Library of Congress Cataloging-in-Publication Data}

\section{Last, George.}

After the "socialist spring" : collectivism and economic transformation in the GDR / George Last. - 1st ed.

p. cm. - (Monographs in German history ; v. 26)

Includes bibliographical references and index.

ISBN 978-1-84545-552-1 (hardback : alk. paper)

ISBN 978-1-78920-108-6 (open access ebook)

1. Collectivization of agriculture-Germany (East)—History. 2. Germany (East) -Economic conditions-20th century. 3. Agriculture and stateGermany (East). I. Title.

HD1492.G2L37 2008

330.943'1087-dc22

2008032694

\section{British Library Cataloguing in Publication Data}

A catalogue record for this book is available from the British Library

ISBN 978-1-84545-552-1 (hardback)

ISBN 978-1-78920-108-6 (open access ebook)

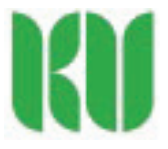

An electronic version of this book is freely available thanks to the support of libraries working with Knowledge Unlatched. KU is a collaborative initiative designed to make high quality books Open Access for the public good. More information about the initiative and links to the Open Access versioncan be found at knowledgeunlatched.org 


\section{of Contents}

List of Figures viii

Acknowledgements ix

List of Abbreviations $\quad \mathrm{x}$

Glossary of Terms xiii

Map of Settlement Pattern in Bezirk Erfurt xvi

Introduction xvii

Bezirk Erfurt $\mathrm{xx}$

Pre-1989 Studies of Agriculture and Rural Society in the GDR xxiii

The Historiography of Agriculture and Rural Society in the GDR

since the Wende xxvi

Sources xxix

Contribution xxxii

\section{Part I}

Consolidation and Control: Collectivisation and Its Malcontents

1 Steps towards Full Collectivisation of Agriculture

The Campaign for Collectivisation 4

Popular Responses to Collectivisation 9

The Limits of Local Agitation 11

The Campaign Intensified 14

The 'Socialist Spring' 18

Conclusion 21

2 The Aftermath of Collectivisation

The Conditions of Collectivised Agriculture $\quad 28$

The Roots of Conflict in the LPG 31

The Insufficiency of the SED State's Apparatus in Rural

Communities 35

Flight to the West 39

The Strength of Popular Dissent 44

The Seeds of Consolidation in the LPG 47

Conclusion 48 
3 Farming behind the Wall

The Limits of Dissent 55

Sources of Continued Instability

Confrontation and Control 63

Conclusion 68

\section{Part II}

Communicating Reform: The Limits of Economic Transformation

4 Steps towards Reform

Changing the Context for Communication of Authority $\quad 78$

Supplying Loyal Cadres 83

New Departures in the Administration of Agriculture 85

Hostility to Change: the Limits of Reform 88

Conclusion 94

5 Resistance, Compromise and 'Cooperation'

The Early Development of Cooperation 101

Grounds for Continuing Hostility to Cooperation 104

Competing Interests and the Obstacles to Persuasion 110

The Ideological Deficit in the LPG 115

The DBD and Voices of Conservatism 117

Uncertainty and the Limits of Transformation

A Changing Context for SED Authority 121

Conclusion 124

6 Critical Transitions

Forced Evolution 132

The Crisis Precipitated 137

Crisis and Confusion in Agricultural Administration $\quad 140$

Administrative Gridlock 145

Conclusion 147

\section{PART III}

Stable Instability: Economic Stagnation and THE END OF TRANSFORMATION

\section{From Ulbricht to Honecker}

The Dynamic 1960s? The Limitations of Life in East German

Agriculture 156

The Failure of Economic Reform 162

Continuities 164

Reconstituting Cooperation 166

A New Structure for Agriculture - A New Context for

SED Authority 169

Conclusion $\quad 172$ 
8 Stabilisation and Stagnation

Consolidation and Conflict 179

Inadequate Industrialisation 182

The End of 'Realistic Plans' 184

Problems of Scale 187

The Failures of Cooperation 191

Rural Development under Honecker 195

Conclusion 198

9 Economic Crisis and Popular Dissatisfaction - the Road to 1989

Popular Dissatisfaction: Pollution, Shortage and Neglect in Rural Society 204

Agricultural Reform 210

Managing Mis-industrialisation 212

Mis-industrialisation or Sabotage? 214

Financial Reform 216

Conclusion 219

Conclusion: The Practice and Problems of Agricultural

Transformation in the GDR

Bibliography

Index 


\section{of List of Figures}

2.1 Illegal Flights from the GDR by LPG members in Bezirk Erfurt, February 1960 to March 1961

4.1 Number of Type I and Type II LPGs vs. number of Type III LPGs in Bezirk Erfurt, 1960-74

5.1 Convergence of rising qualification levels and declining workforce in Bezirk Erfurt, 1960-78 


\section{of| Acknowledgements}

First and foremost, I would like to thank Professor Mary Fulbrook, for her guidance and encouragement. I am grateful too to all those in the German Department at University College London, in particular Esther von Richthofen, Dr Mark Hewitson and Dr Jeanette Madarasz, whose academic advice and moral support were a great help. In Erfurt, I am indebted to Karin Badelt for the loan of her agricultural textbooks, her explanations of technical matters of agricultural policy and her help in contacting interview subjects. I am indebted too to the staff of the Thuringian State Archives in Weimar for their labours in seeking out and providing me with endless files. I would also like, in particular, to mention my father and my late mother for their love and constant encouragement over the years. Finally, I am grateful to the Arts and Humanities Research Council for the financial support without which my research would not have been possible. 


\section{of List of Abbreviations}

ABV

AIV

BArch

\section{BDVP}

BGL

BHG
Abschnittsbevollmächtigter (Local Police Officer)

Agrar-Industrie-Vereinigung (Agro-Industrial Union)

Bundesarchiv (Federal Archive)

Bezirksbehörde der Deutschen Volkspolizei (Regional Authority of the German People's Police)

Betriebsgewerkschaftsleitung (Factory trade union leadership)

Bäuerliche Handelsgenossenschaft (Farmers' Trade Cooperative)

DBD Demokratische Bauernpartei Deutschlands (Democratic Farmers' Party of Germany)

DBK Deutsches Bauernkongress (German Farmers' Congress)

DDR Deutsche Demokratische Republik (German Democratic Republic)

DFD Demokratischer Frauenbund Deutschlands (Democratic German Women's Association)

DSF Gesellschaft für Deutsch-Sowjetische Freundschaft (Society for German-Soviet Friendship)

FDGB Freier Deutscher Gewerkschaftsbund (Free German Trade Union) 
FDJ Freie Deutsche Jugend (Free German Youth)

GAP Gemeinsame Abteilung Pflanzenproduktion (Common Unit for Crop Production)

GDR German Democratic Republic

GO Grundorganisation (Basic Party Organisation)

IM Inoffizielle Mitarbeiter (Unofficial staff recruited by the Stasi)

JEA Jahresendabrechnung (End of Year Accounts)

JEV Jahresendversammlung (End of Year Assembly)

JHV Jahreshauptversammlung (Main Annual Assembly)

KAP Kooperative Abteilung Pflanzenproduktion (Cooperative Unit for Crop Production)

KAS Kreisarchiv Sömmerda (District Archive Sömmerda)

KBK Kreisbauernkonferenz (District Farmer's Conference)

KLR Kreislandwirtschaftsrat (District Agricultural Council)

KOG Kooperationsgemeinschaft (Cooperative Community)

KOR Kooperationsrat (Cooperative Council)

KOV Kooperationsverband (Cooperative Union)

KPKK Kreisparteikontrollkommission (District Party Control Commission)

KPdSU Kommunistische Partei der Sowjet Union (Communist Party of the Soviet Union)

LPG Landwirtschaftliche Produktionsgenossenschaft (Agricultural Collective)

LPG P LPG Pflanzenproduktion (Agricultural Collective for Crop Production)

LPG T LPG Tierproduktion (Agricultural Collective for Livestock Production)

MfS Ministerium für Staatssicherheit (Ministry for State Security)

MTS Maschinen-Traktoren-Station (Machine and Tractor Station)

MV Mitgliederversammlung (Members' Assembly)

Nazi Nationalsozialist (National-Socialist)

NES New Economic System 
NÖS Neues Ökonomisches System (New Economic System)

NSDAP Nationalsozialistische Deutsche Arbeiterpartei (National Socialist German Worker's Party)

NVA Nationale Volksarmee (Army of the GDR)

RdB Rat des Bezirks (State Regional Council)

RdG Rat der Gemeinde (State Commune/Village Council)

RdK Rat des Kreises (State District Council)

RLN (B) Rat für Landwirtschaft und Nahrungsgüterwirtschaft (Bezirk), (Regional Council for Agriculture and the Food Industry)

RLN (K) Rat für Landwirtschaft und Nahrungsgüterwirtschaft (Kreis), (District Council for Agriculture and the Food Industry)

SAPMO Stiftung der Parteien und Massenorganisationen (Foundation for Parties and Mass Organisations)

SED Sozialistische Einheitspartei Deutschlands (Socialist Unity Party)

SPK Staatliche Planungskommission (State Planning Commission)

Stasi Staatssicherheitsdienst (State Security Service)

ThHStAW Thüringisches Hauptstaatsarchiv Weimar (Thuringian Main State Archive)

VEAB Verein der Erfassungs- und Aufkaufsbetriebe (Union of Produce Collection and Purchasing Companies)

VEB Volkseigener Betrieb (People's Own Factory)

VEG Volkseigenes Gut (lit. People's Own Estate i.e.: Stateowned farm)

VdgB Verein der gegenseitigen Bauernhilfe (Farmer's Mutual Aid Association)

VKSK Verein der Kleintiergärtner, Siedler und Kleintierzüchter (Association of Small Gardeners, Settlers and Small Animal Breeders)

VPKA Volkspolizeikreisamt (District Police Office)

Vw Volkswirtschaft (National Economy)

ZGE Zwischengenossenschaftliche Einrichtung (Intercollective Institution)

ZK Zentralkomitee (Central Committee) 


\section{gy Glossary of Terms}

Betriebsegoismus Enterprise Egotism: Catch-all criticism attributed to farms and factories thought to be acting in their own rather than the common interest.

Bezirk Administrative Region: In 1952, the Länder which made up the territory of the GDR were divided into smaller administrative regions, mapping the state bureaucracy on to the party bureaucracy.

Bezirksleitung Regional SED Administration.

Bezirksparteiaktivtagung Assembly of select SED members with leading roles in particular fields in the region.

Bezirksvorstand The leading members of one of the bloc parties in the Bezirk, e.g. the DBD.

Delikat Chain of shops established to sell 'luxury' food items to the population.

Eingaben der Bevölkerung People's Petitions: formal complaints made in written or verbal form to any state or party official or body. These were essential to the gauging of popular opinion and popular concerns.

Genossenschaftliche Demokratie Collective Democracy: the practice of including collective farm members in the running of an LPG through ballots in the members' assemblies on specific issues, as well as election of members to the directing board and advising commissions of the LPG.

Großbauer Wealthy farmer: technically, any farmer owning more than 20 hectares of land, or operating a capitalistic enterprise.

Kleinbauer Small farmer: technically, any farmer owning less than 5 hectares of land.

Komplexeinsatz Integrated deployment: the use of several machines (often from several LPGs) in conjunction usually during the harvest.

Konsum Standard all-purpose shop, often the only retail outlet in small villages. 
Kooperationsgemeinschaft Cooperative Community: The collective term for two or more LPGs contractually bound to cooperate with one another in some aspect of agricultural production.

Kooperationsrat Cooperative Council: A body compromised of delegates from each of the LPGs in the cooperative community, usually the LPG chairmen but also other leading members of the LPG, including brigade leaders or SED party secretaries. Meetings of the council were also attended by village mayors, although their opinions were not always welcomed by LPG chairmen. The primary purpose of the council was to arrange and agree upon the terms on which LPGs, and later LPG Ps and LPG Ts cooperated with one another.

Kooperationsverband Cooperative Union: A body with its own council of delegates, designed to coordinate the relationship between food industries and LPGs. Cooperative unions were established to organise the production of specific crops or food products involving a number of LPGs with other institutions (e.g. slaughterhouses) in the vertical chain of production over a wide territory, e.g. from the raising of calves through to their processing as sausage.

Kreisverband District authorities of one of the bloc parties e.g. DBD.

LPG-Aktiv LPG Committee: As a pre-cursor to the formation of an SED Party Organisation, these Aktivs were designed to bring SED and nonSED members together who were active in promoting and developing collective farming practices within an LPG.

Nebenerwerbsbauer Part-time farmer: a large number of part-time farmers were forced to abandon their land to an LPG and receive a share of the produce in return as part of the collectivisation. In the 1980s in particular, however, industrial workers were encouraged to take up farming on small allotments, which could not be easily fitted into the large field systems of gigantic LPGs, in order to boost production.

Neubauer New Farmer: A beneficiary of the postwar land reforms.

Offenstall An open stall shed: designed as a cheap and easily constructed shed for holding rapidly increasing numbers of livestock during the late 1950s and early 1960s. Poor planning and shoddy materials gained them a reputation for being counterproductive.

Ortsbauernführer Local Farmers' Leader: Nazi-affiliated local agricultural functionary during the Third Reich.

Parteitag Party Congress. 
Sozialistische Betriebswirtschaft Socialist Business Economics: system of accounting and incentive measures designed to improve the efficiency of financial planning under the terms of the New Economic System.

Umsiedler Refugees from the East settling in the GDR.

Vorstandssitzung Board meeting: LPGs were run by chairmen supported by boards of LPG members elected every two years. The board and chairmen were to meet ideally every week to discuss the business of the LPG, managing everything from matters of discipline (often drunkenness) in the workforce, to questions over the long-term development of the LPG. Preparing the resolutions which were put to the vote in the full members' assemblies, they were a vital part of the functioning of 'collective democracy', qualifying the power concentrated in the hands of the chairman.

Wehrmacht The army of the National Socialist regime. 


\section{This image is not available in this open access ebook due to rights restrictions.}

Map of Settlement Pattern in Bezirk Erfurt

Source: Rat des Bezirkes, Bezirksplankommission March 1976, ThHStAW, Bezirksparteiarchiv der SED Erfurt, Bezirksleitung der SED Erfurt IV /C/2/13-479, p. 303.* 


\section{of Introduction}

It is commonly recognised that the German Democratic Republic (GDR) was a dictatorship. Under the auspices of the Socialist Unity Party (Sozialistische Einheitspartei Deutschlands or SED), whose dominant position in government was never legitimated by free democratic elections, judicial, executive and legislative powers were also never rigorously separated, compromising the rule of law and allowing the infringement of basic human and civil rights in the name of the party's ideological goals. ${ }^{1}$ The nature of the SED dictatorship, as it changed over the forty years of the GDR's existence, remains nonetheless a matter of considerable debate among historians seeking to explain both the causes of the state's longevity and its ultimate collapse. Using material largely unexamined since the collapse of the GDR, this book addresses the role of low-level political and economic functionaries in the organisation and management of the collective farms (Landwirtschaftliche Produktionsgenossenschaften or LPGs), and in the implementation and development of agricultural policy from the agitation campaigns of the 'Socialist Spring' in 1960 to the development of industrial-scale agriculture during the 1970s and 1980s in Bezirk Erfurt. ${ }^{2}$ In so doing it aims to illuminate the changing practice of authority (Herrschaft) at the grass roots and contribute to our understanding of the interrelated history of politics and society in the middle two decades of the GDR's existence, as the SED regime gradually attained an unprecedented level of stability, yet found itself increasingly vulnerable to financial collapse.

The implementation of SED agricultural policy occurred via an administrative network that was by no means simply a well-oiled conduit of dictatorial authority but was itself evolving. At the grass roots the mere creation of the LPG and the establishment of a hierarchy of chairman and work brigade leaders on paper did not automatically create a channel for the consistent transmission of information and authority. Moreover, farmers themselves were no willing dupes, nor indeed merely victims of the imposition of state power. Particularly with regard to agriculture, where knowledge of the locality and the intimacy of the connection between the farmer and his land and livestock retained an 
economic value (above all under the constraints of the shortage economy), the practice of authority necessarily involved a - albeit unequal dialogue. The aspirations and policies of those leading the dictatorship were necessarily reshaped to some extent in accordance with the interests and objections of LPG farmers on the ground. The context in which this process occurred was defined in large part by the shifting educational and political background of the LPGs' leading functionaries and their relationship with their constituent farmers on the one hand and with the state and party hierarchy on the other.

During the course of the 1960s and 1970s, the SED leadership pursued the development of agriculture on an industrial scale and sought to make the process of agricultural production not only more successful but also more responsive to the demands of the economic system more predictable and thus more plan-able. Against the background of technological development and economic fluctuation, the farming population themselves were necessarily incorporated into a new apparatus of agricultural administration, whose basic unit was the LPG. In the process their understanding of farming - not least of ownership and responsibility to the land - and their relationship with the state and to their fellow farmers underwent considerable, if gradual, redefinition. The contexts in which those working in agriculture pursued their careers and conceived of (and foresaw) their future in the GDR were very different in the late 1970s than they had been in the late 1950s or even the late 1960s.

The changed context of the late 1970s was the product of considerable conflict. Over the years the limits on the expression of divergent opinion among collective farmers and on local resistance to the implementation of SED agricultural policy were settled incrementally. It was also the product, however, of a (albeit limited) compromise, in which the aspirations of the SED leadership were necessarily mitigated by the process by which its authority was transmitted and received. The attempts of collective farmers to assert their own interests not only in spite of or in contradiction to, but also increasingly in conjunction with, those of the SED culminated by the late 1970s in the establishment and consolidation of essentially new structures of farm organisation and stable systems of agricultural administration. These new structures appeared to guarantee steadily improving incomes and working conditions as well as steady (and plan-able) improvements to productivity. A degree of internalisation or at least acceptance of the norms of the socialist system certainly took place in the 1960s and 1970s among the GDR's farmers, driven to a large extent by the reduction in the size of the agricultural workforce and by a steady growth in the proportion of 
those with technical training in the forms and methods of socialist agriculture. This was matched by growing recognition of the limitations on rights to property, to participation in decision making and self-determination and to the articulation of complaint by the late 1970s.

Furthermore across the economy and society as a whole in the GDR in the 1970s, the end of radical social upheaval and economic austerity marked a high point for the stability of the SED regime. Internationally recognised in 1972 and a signatory to an international declaration on human rights in Helsinki in 1975, the GDR appeared outwardly to have achieved an unprecedented degree of harmony both domestically and internationally. The introduction of welfare and consumerist measures designed to bring about immediate improvements to living conditions, alongside continually improving wages, brought too an unprecedented degree of affluence to the population at large. For many, if not all, members of the collective farms levels of income, levels of educational attainment and working conditions also reached an unprecedented high. Improvement was by no means universal, however. Moreover, underlying this harmony were the beginnings of serious financial crisis.

The cost of welfare and consumerist policies (as well as a failed yet costly attempt to develop a high-tech electronics industry) in the GDR came at the price of an ever-increasing national debt, much of it to West German banks. This debt, compounded by the negative impact of increases in oil prices on the international markets and the reduction of some financial support from the Soviet Union, began during the 1980s seriously to undermine the GDR's economic stability. This had serious consequences for agriculture in the GDR, which more than ever depended on the ability of the rest of the economy to supply it with machinery, fuel and chemical fertiliser. Under increasingly desperate economic conditions, the mistakes of overindustrialisation of agriculture and the vulnerability (when faced with shortage) of the structures established to coordinate agricultural production were exposed. Working conditions in farming became thus increasingly fraught with crises at the same time as rural communities in general were badly hit by shortages in the supply of consumer goods and a growing environmental crisis.

By the end of the 1980s, the effectiveness of the system of agricultural organisation was being seriously undermined by economic stagnation. As the GDR headed towards bankruptcy and the prospects of future stability in agriculture, as in other sectors of the economy, receded, so the ability of the SED leadership to satisfy the expectations which it had set itself and encouraged not only the population at large but also its constituent functionaries throughout the state and party network to adopt, 
seemed increasingly unattainable. If the basis on which the SED regime could achieve relative stability had been established in the 1970s, by the late 1980s this stability was increasingly fragile. The clear superiority of the West German economy and the failure of the SED to sustain the standards it had set itself, or even play the role it claimed of protecting the interests of the working class and the peasantry, left it with as little popular support in the countryside as it had in the towns of the GDR. Ever-growing problems of production and increasing differentiation in the quality of life and the standard of working conditions in rural communities had compromised the validity of the material and epistemic bases of the SED leadership's claim to legitimacy. The East German population had been encouraged to expect consistent (planned!) improvement to living and working conditions across the economy and society. These expectations had been sorely disappointed.

\section{Bezirk Erfurt}

In order to maintain a focus on the grass-roots relations between the party, state and farming collectives, the scope of this study is limited to the villages of Bezirk Erfurt, the largest and westernmost of the three regions (Bezirke) formed in 1952 to replace the former Land Thuringia in the southwest corner of the GDR. While being roughly average in size and number of inhabitants compared with the GDR's other Bezirke, it has the added advantage of allowing the examination, from a regional perspective, of some of the broader issues faced by the GDR during its existence. Religiously, the population of the Bezirk, in containing a concentrated minority of Catholics in the northwestern Eichsfeld region alongside Protestants of both the Lutheran and Reformed Evangelical churches, reflected the mixture of Christians in the GDR as a whole. Its long border with the Federal Republic makes possible too examination of the regional impact of the erection of the Wall in August 1961. Five districts (Kreise) in the Bezirk bordered West Germany: in the far north the district centred on the town of Nordhausen, in the northwest the Eichsfeld districts around Heiligenstadt and Worbis and to the southwest, Eisenach district. Lying between the Harz mountains to the north and the Thüringer Wald to the south, Bezirk Erfurt covered 7,349 $\mathrm{km}^{2}$ and comprised thirteen rural districts and two urban districts (Weimar and Erfurt) subdivided in 1970 into 803 settlements of which forty-nine were classed as towns. ${ }^{3}$

Prior to the GDR's existence, the state of Thuringia was largely cultivated by relatively small family farms, lacking almost any grand estates 
of the size that existed in the northeast of the country. At the end of the war 98 per cent of the farms were under 50 hectares in size, cultivating 84 per cent of the arable land. ${ }^{4}$ As a result, the effects of the initial land reform - the expropriation of large landowners and the parcelling of property to be handed out to Neubauern ('New Farmers': largely industrial workers, refugees or formerly landless farm labourers) - was felt less severely here than for example in Mecklenburg and Brandenburg, where over 40 per cent of arable land was redistributed. ${ }^{5}$ Only with the second stage of the land reforms, which were carried out as part of denazification measures against farmers with up to 100 hectares and which lasted until 1950, did the proportion of those affected increase significantly. With a steady influx of refugees and expelled Germans from the former eastern territories into Thuringia after the war (albeit in fewer numbers than in most of the rest of the GDR), a large proportion of rural communities were required to accommodate the newcomers. ${ }^{6}$ As recent work on the fates of the so-called 'Umsiedler' (refugees from the East) in the GDR has shown, a relatively small proportion of these newcomers were able to benefit from the land reforms and become so-called Neubauern. ${ }^{7}$ Rather the vast majority of newcomers to rural communities found initial employment as agricultural labourers, replacing the foreign workers and prisoners of war who had been freed on the collapse of the Nazi regime, and making up for the absence of the generations of young men killed during the war. Many of those employed in this way had, however, no experience of farming nor saw their long-term future in agriculture, hoping either for a return to their homeland or at least employment in their former trades. Even those who had sought and received land as part of the land reforms found in many cases that it did not enable them to make a sufficient living - not least because the quality of the land and the livestock that they were allocated was seldom of the best. ${ }^{8}$ Consequently, over the course of late 1940s and early 1950s, encouraged by the state, there was a steady exodus from rural communities and agricultural employment into urban settlements and industry. The proportion of newcomers among landless labourers, which had been nearly 50 per cent for the GDR as a whole in 1949 (though far lower in Thuringia), was thus greatly reduced by the time the collectivisation of agriculture was under way. ${ }^{9}$ For the majority of farmers in Bezirk Erfurt, therefore, vigorous attempts to persuade them to collectivise in the 1950s represented the first major disruption to the organisation of farmland as a result of communist control since the war.

Of course conditions for farming in the Bezirk varied considerably. Purely in terms of the nature and quality of the land, the Bezirk may be 
divided into three basic sections. Firstly, there were the flat fertile arable lands of the Thuringian basin, which included parts of the districts of Weimar-Land, Bad Langensalza, Sömmerda, Erfurt-Land and Apolda. Farms in these areas tended to be the most successful with high yields of crops and correspondingly well-fed livestock. As a consequence those who farmed them could on the whole afford to remain full-time farmers; secondly, there were the highlands in the north of the Bezirk which included much of the districts of Worbis, Heiligenstadt and Nordhausen. These areas, in contrast, had a much smaller proportion of arable land, relying heavily on pasture land for livestock feed. Owing to the relative poverty of farming in this part of the country, there was a long tradition of migration by men looking for work in mining and industry as well as on farms and estates elsewhere, leaving large numbers of small-scale farms (most well under 5 hectares) in the hands of women and the elderly. Similarly, to the far south of the Bezirk, in the southernmost parts of Arnstadt, Eisenach and Gotha districts, the beginnings of the hilly Thuringian forests reduced agricultural production to a minimum. Much of the rest of these districts, however, constituted a third section, along with districts such as Mühlhausen and Sondershausen, in which relatively successful farmers each with between 10 and 20 hectares of land predominated..$^{10}$

The pattern of urban settlement and the development of industry within the different districts also varied considerably and inevitably made an impact on the nature of rural communities and agricultural activity. With the hardening division of Germany following the war, the prewar economic structure of what had become the Soviet zone could no longer be maintained. It was essential that the exploitation of native raw materials be stepped up and new heavy industry as well as manufacturing be developed in the GDR. As a consequence, during East Germany's own (less flamboyant) economic miracle in the 1950s, a rapid expansion of industry and urban settlement took place which not only drew on the agricultural workforce (as I have mentioned with regard to Umsiedler) but on agricultural land as cities expanded and incorporated rural areas. Moreover, some rural communities began to lose their dominantly agricultural character, by their proximity to industrial centres and the high proportion of commuting members of the industrial workforce. With the further expansion of industry into previously exclusively rural areas and the growth of the commuting population, the combination of small-scale agriculture with industrial employment accounted for a not insignificant proportion of farming in some districts in the 1950s. In Bezirk Erfurt, in the vicinity of the many small towns in the Gotha and Eisenach districts in particular, there was 
a tradition of part-time farmers and smallholders who also worked in industry. The expansion of mining operations, particularly the potash mines in Nordhausen, had a similar impact on the surrounding rural communities that supplied much of the workforce.

While progress in industrialisation during the 1960s and 1970s alongside the mechanisation of agriculture did result in a reduction in the numbers living in small rural settlements in conjunction with the drop in the agricultural workforce, a considerable number of people in the Bezirk continued to commute from villages. ${ }^{11}$ Thus although the agricultural and food production sectors dominated the economies of certain Kreise such as Bad Langensalza, Weimar-Land and Erfurt-Land, a large proportion of the inhabitants of these areas were employed in industrial centres, notably in Sömmerda and Erfurt. The largest factories in the Bezirk, such as the People's Own Factory (Volkseigener Betrieb or VEB) 'Office Machine Works Sömmerda', VEB 'Automotive Works Eisenach' and VEB 'Electric Works Erfurt', operated largely in the manufacture of machinery and vehicles and from the 1970s electrical goods and technology. Elsewhere in the Bezirk textile and chemical industries were developed, such as the VEB 'Chemicals Rudisleben' near Arnstadt and the VEB 'Cotton Weaving Leinefeld' in Worbis district. ${ }^{12}$ In 1971, of approximately 600,000 people in active employment in the Bezirk, 14.5 per cent worked in agriculture and 38 per cent worked in industry. The numbers of those in the Bezirk working in agriculture in the 1970s continued to drop - albeit more gradually than during the 1960s. By the beginning of the 1980s, the size of the agricultural workforce in the Bezirk, as in the rest of the GDR, did stabilise, however, as the minimum level of manpower required to sustain production was reached.

New recruits to the LPGs in Bezirk Erfurt in the 1970s joined farms much changed since full collectivisation in 1960, which were nevertheless by no means uniform in size, structure and organisation. By the 1980s a peculiarly socialist modernisation and (mis-)industrialisation of farming had taken place in the GDR. How this process occurred in the specific, yet not wholly unrepresentative, circumstances of the territory of Bezirk Erfurt and the impact it had on working and living conditions for the rural population forms the background to the shifting relations between state and society with which this study is concerned.

\section{Pre-1989 Studies of Agriculture and Rural Society in the GDR}

Given the declining status of farming within the economies of Europe's industrialised countries and the proportionate growth of the urban 
population, the attention of historians of postwar Europe in general has shifted proportionately away from the development of rural society. ${ }^{13}$ Nevertheless the significance and immediacy of the upheavals in rural society in the Soviet zone of occupation in Germany after the Second World War and then the GDR has made it something of an exception in this regard. The social development of the countryside as well as the politics of agriculture in the Soviet Zone and GDR were the subject of interest in the West from the beginnings of the land reform in 1945 and the first drive for collectivisation of agriculture in the early 1950s, provoked in part by the immediate plight of the steady flow of farmers and landowners fleeing the GDR as a result. Equally, the significance of the transformation of the countryside for the SED regime, both in terms of the ideological battle for the rural population and in terms of its goals of autarkic food production, saw a large number of historical and political works published in the GDR itself in clarification as well as justification of socialist agricultural policy. Literature has thus come from a number of different quarters in both East and West, with works by historians and journalists as well as social scientists alongside more technical literature on specific agricultural issues.

A range of different types of studies was produced in East Germany prior to the Wende on the subject of agriculture, village development and collective farm management. While much of the content is formulaic and ridden with ideological jargon, there was scope too for debates on the future direction of agriculture, particularly during the 1960s, amid a climate of innovation generated by the new economic policy and with the exact path of development for the farm collectives not yet fixed. The scale and complexity of agriculture and (would-be) autarkic food production in a planned economy raised numerous questions for debate among agricultural scholars as well as economists and theorists of socialist management. While the more accessible works on these subjects often did not necessarily reflect the real problems of the average farming collective, they and other more technical publications nonetheless highlight the potential for debate, albeit within certain bounds. ${ }^{14}$

A number of works published in the late 1960s and 1970s in the GDR addressed the progress of village development, triumphantly highlighting the success of the policy of 'Annäherung' ('converging') of living standards in villages and towns with examples of modern housing in rural areas and the availability of modern urban amenities in the countryside. ${ }^{15}$ Alongside these largely superficial analyses, several sociological studies of aspects of rural society were carried out in the 1970s and 1980s, largely under the direction of Kurt Krambach. ${ }^{16}$ While again couched in the rhetoric of progress, these nonetheless looked more 
closely at the specific issues facing rural society, such as the problem of the loss of young people to the towns, and often used interesting, if ideologically skewed, questionnaires to gauge the opinions of farmers on the latest developments of agricultural policy and the position of the farmer within the collective.

The development in the 1970s of the large industrial specialised production units in some advanced LPGs also prompted interest from journalists within the GDR. The reportage on life and work in the industrial milking station in Berlstedt, Kreis Weimar by Ursula Püschel, a cultural functionary and literary critic, is notable for the mixture of workers' and managers' perspectives on the problems and successes which she portrays. ${ }^{17}$ More controversially, the recorded testimonies of workers and managers in the specialised fruit farms of the Havelland in Bezirk Potsdam, edited by Gabrielle Eckart in the 1980s, highlighted the everyday problems faced by a range of different people living and working in a rural area since the development of specialised industrial agricultural production. ${ }^{18}$ Both these works were published in West Germany in the 1980s, filling a gap in West German conceptions of the state of East German agriculture.

The focus of most Western studies of East German agriculture and society before the Wende concentrated on the period of the land reforms after 1945 and the later process of collectivisation. ${ }^{19}$ In the 1950s and 1960s, this was to some extent the natural result of the Cold War ideological division, with the emphasis on the 'totalitarian' control and repression exerted on the German population by the SED regime. With the thawing of relations between East and West from the early 1970s, a number of Western analysts began to examine the current state of development in the GDR with a more favourable predisposition. As a result, analytical works on the functioning of the LPGs and the development of specialisation and industrial-style production were published, which presented a more positive picture of agriculture than had hitherto been produced..$^{20}$ The direction of agricultural policy in the GDR towards larger-scale production units was contrasted favourably with the limited small-scale family farms that still predominated in West Germany. ${ }^{21}$ Enthusiasm for the socialist model, however, was tempered by the 1980s as it failed to prove more efficient when compared with the continuing superiority of West German agricultural production levels. Furthermore, the social and environmental impact of the extreme extent of specialisation of agriculture in the GDR made for further points of criticism. ${ }^{22}$ Although in many respects accurate, ultimately all Western analyses of the contemporary state of agriculture in the GDR were largely limited to the information provided by party-approved sources- 
making debates in West Germany on the success or not of the East German transformation of the countryside as much a matter of opinion as of evidence. ${ }^{23}$

\section{The Historiography of Agriculture and Rural Society in the GDR since the Wende}

During the early 1990s political divisions continued to find a reflection in analyses of the effects of the Wende on rural society and the future of agricultural organisation in the new Germany. Competing evaluations of the morality as well as the practical validity of the collective farming model were made, as particularly East German commentators sought to reassert the positive impact on rural society of the development of the LPG and the relative success of agriculture in the GDR, compared with the rest of the economy, against criticism from West German academics and renewed interest in the land reforms and the forced collectivisation. ${ }^{24}$ Since the collapse of the GDR and the reunification of Germany, historical as well as journalistic debate on agricultural policy and rural society in the GDR has, however, primarily focused again on the land reforms and the development of collectivisation in the 1950s and early 1960s. Amid ongoing disputes over land ownership and claims for compensation from both East and West Germans, much journalistic interest was provoked by the chance to re-examine the issues of expropriation and forced collectivisation as part of the process of coming to terms with the legacy of the SED dictatorship in the countryside. Against this background, historians too have focused on reexamining the earlier periods of agricultural development in the GDR. As the eminent German agricultural historian Ulrich Kluge wrote in 2001,

no phase of development in GDR agriculture has been so closely investigated as the initial years 1945/49 up to the conclusion of collectivisation in the early 1960s. Almost three decades are sinking into oblivion. Only the unextinguished claims for land and farm property from farmers who fled to the west under the pressure of political coercion made headlines after reunification, which agricultural studies then took up, presented and evaluated. ${ }^{25}$

Taking the opportunity to use newly available archival sources, several historians have re-examined the structure and organisation of agriculture and the impact of agricultural policy on rural society in the postwar period and under the SED dictatorship up to the early $1960 \mathrm{~s}^{26}$ Looking broadly at agricultural development and SED policy, particularly Arnd Bauerkämper has re-examined the processes of land reform 
and collectivisation in northern East Germany using archival sources to assess primarily the balance between the continuity of traditional social structures and the consequences of (forced) socialist modernity in rural society and farming. ${ }^{27}$ Jens Schöne too has provided new insights into the development of the policy of collectivisation during the 1950s, ${ }^{28}$ while new archival research by Theresia Bauer on the development of the German Farmers' Party (Demokratische Bauernpartei Deutschlands or DBD) up to 1963 has illuminated the functions and attitudes of party members at the grass roots during the process of collectivisation. ${ }^{29}$ Specifically with regard to Bezirk Erfurt a collection of excerpts from documents detailing the collectivisation process in each of the districts of the Bezirk has been compiled by Jürgen Gruhle, providing interesting source material for the activities of party and state functionaries at local and regional level in the administration of agriculture in the 1950s - if little actual analysis. ${ }^{30}$

In comparison, analyses of agriculture and rural society post full collectivisation are relatively few in number. Specific aspects have received some examination by social historians. For example, Dagmar Langenhahn and Sabine Ro $\beta$ have written on the patterns of qualification attainment and career advancement for women farmers in the 1970s and 1980s. ${ }^{31}$ Thomas Lindenberger has written on the local police constables' involvement in overseeing agricultural transformation in the 1950s and 1960s; Patrice Poutrus has written on the phenomenon of the 'Goldbroiler' roast chicken, as part of a growing consumer culture in the 1970s and 1980s for which industrial-scale agricultural production was essential; and Christel Nehrig has addressed the changing position of the chairmen of state-owned farms up to $1970 .{ }^{32}$ A number of studies of individual villages in the GDR have also dealt with the combination of influences of modernisation and invasive party policy on the peculiar traditions of the rural milieu after collectivisation. Daphne Berdahl's anthropological study of a Catholic border village in the Eichsfeld, while focusing primarily on the experience of transition following the Wende, retells her subjects' retrospective understanding of life between duty as Catholics and as GDR citizens in a highly sensitive region during the latter course of the GDR. ${ }^{33}$ Barbara Schier's study of the village of Merxleben between 1945 and 1990 reconstructs elements of everyday life in the village as well as analysing the socioeconomic effects of SED agricultural policy over this period in order to contrast the reality with the socialist ideal of 'a village community of an historically new type'. Schier, on the basis of extensive interviews with villagers and LPG members, also provides analysis of the functioning of the LPG caught between its special status as a model collective and 
its own internal conflicts, particularly in the early years of its development. ${ }^{34}$ Antonia Maria Humm's study of the village of Niederzimmern (in comparison with a similar village in West Germany), between 1952 and 1969, demonstrates the complex relationship between some aspects of SED policy and the response to its implementation within the village and the LPG. She also provides some insights into the functioning of the local government in the village and other local socialist organisations, which go beyond much of the available literature on the subject of political institutions at and below district level. ${ }^{35}$

With specific regard to the development of socialist agricultural policy and rural society since the end of the collectivisation campaign, there have, however, been few convincing in-depth studies that make satisfactory use of archival sources now available. ${ }^{36}$ Many of the most interesting works on the subject of agriculture in the GDR in the late 1960s, 1970s and 1980s published since the Wende are the accounts by former LPG members and functionaries of the development of their LPG and their experiences as collective farmers. While one must be careful to see such accounts in the context of developments since the Wende, they need not be dismissed as valueless. ${ }^{37}$ With regard to Thuringia, Manfred Kipping's local history of farmers in Oberwiera between 1945 and 1990 provides some interesting insights into his experience as an LPG functionary amid the constrictions of SED policy on cooperation and specialisation. ${ }^{38}$ Similarly, the history of agriculture in Worbis district by a former LPG chairman, Dr Heinrich Klose, provides an outline of local agricultural development as well as some impression of his own experiences as an LPG chairman. More broadly, a volume published for the Thuringian Interior Ministry gives a methodical overview of the development of agriculture in Thuringia after collectivisation, reaching conclusions as to the technical deficiencies of policy decisions made during the GDR - in particular the problems associated with the overexpansion of the farming units. The particular value of this book, however, is the transcribed interviews with former LPG functionaries that it contains. ${ }^{39}$

There are thus some considerable gaps in the research done since the Wende on SED agricultural policy and the development of rural society in the GDR from the mid-1960s onwards, which this book is designed to fill. Articles by Christel Nehrig and in particular Dagmar Langenhahn in recent years have raised some of the questions which have yet to be thoroughly addressed with regard to the structure, formation and changing organisation of LPGs and the implementation of SED agricultural policy through the later 1960s and 1970s. Langenhahn, for example, most recently has written on the position of leading agricultural functionaries in the 1970s as they responded to the problems 
of cooperation between LPGs and the separation of crop and livestock production. More than anything, however, these articles highlight the need for greater research in precisely these areas. ${ }^{40}$

The process of consolidation of LPGs, and the development of cooperation, industrialisation and specialisation in agriculture as they transformed the working conditions of farmers and affected the living conditions of rural communities are essential to a complete picture of the workings of the SED regime and the stability as well as the failure of the GDR. The day-to-day working of the collective farms - the experience of 'collective democracy' within the LPG, the reception of and reaction to SED agricultural policy by collective farmers and in particular the pivotal role of LPG functionaries in the dual transmission of authority and information - needs to be more definitively assessed as it varied over time. Investigation into the structures of authority in the administration of agriculture and rural communities via the bureaucracies of state and party and the significance of the presence or absence of strong SED groups in rural areas versus those of other bloc parties are essential to understanding a large proportion of the politics, economics and society of the GDR. In order to gain an effective view of the network of institutions and influences shaping agriculture and rural society, this book seeks to provide a limited regional study aiming thereby to go beyond the specific intricacies of a study of a single LPG or village, yet retaining a focus on the grass roots of state and society.

\section{Sources}

My sources come predominantly from the archives of a range of institutions concerned with rural affairs at different levels of the party and state hierarchies. My intention is both to gain a closer perspective on the functioning of the regime at the grass roots within one Bezirk and to develop an understanding of the process of policy implementation and information transfer within the various administrative hierarchies from the regions to the centre. Consequently the bulk of my sources come from the level of the Bezirk and Kreis administrations, which played a naturally key role in the transmission of information and the process of policy implementation between the centre and the regions. Nevertheless I have also examined the files of the various figures and institutions with an influence over the development of rural affairs at a national level, on the one hand, and on the other the documents of individual LPGs - primarily the minutes of board meetings and members' assemblies - and of individual SED party organisations. 
In accordance with my intention to gain a picture of the experience of 'ordinary' East Germans and the low-level functionaries operating primarily in the LPGs and other institutions at a local level, I have paid particular attention too to those sources that highlight local concerns. Thus alongside general mood and opinion reports compiled by the regional administration (Bezirksleitung) of the SED, the regional leadership (Bezirksvorstand) of the DBD and the State Regional Council (Rat des Bezirkes), among others, I have used the files of district state and party administrations as well as samples of Eingaben der Bevölkerung (People's Petitions) and reports on public village meetings. Where possible I have used police, Stasi and SED Party Control Commission reports as evidence not only of state and party discipline and law enforcement methods but also as sources describing local circumstances. With these as with the other archival sources I have sought where possible to balance statistical evidence with evidence of contemporary opinion among the rural population. In addition, I have carried out a number of interviews with former functionaries in LPGs as well as in the Kreis and Bezirk administrations of party and state which have aided my understanding of some finer points of state and party policy as well as farmers' responses to the same.

Dealing with the documents of a vast bureaucracy, one has to be aware that even if one examines a huge quantity of documentary evidence, there is nonetheless considerable room for a distorted picture to be presented, in which minor concerns take on a greater significance in the surviving sources, or in which the concerns of the bureaucrats are unrepresentative of the concerns of those with whom they are dealing. Nonetheless, this in itself is revealing of the manner in which the bureaucracy functions and the relationship between the various operatives of the regime, those above and below them in the hierarchy and their relationship with the system and the society which they served. The documents of the system - in their falsehoods, vagueness or accuracy - provide in themselves valuable insight into the manner in which the administration functioned and the tensions within it. There is no doubt that there is a regularisation of the bureaucracy involved in running collectivised agriculture in the planned economy which is visible in the style as well as content of the sources. There are advantages and disadvantages to the historian in this respect. Documents of the late 1950s and early 1960s, particularly in the LPGs and at the lowest levels of the party and state bureaucracy, are often more revealing as a result of their lack of ideological polish or formulaic content. By the same token, the increasing competence of the report writers in the 1970s and 1980s, in their selection of information and its presentation within a 
fixed ideological framework, compromises the value of the document as a source for the event or the issue under discussion. Nonetheless, the value of earlier reports as descriptions of actual events or circumstances may be compromised too by the sheer inconsistency of the picture presented and by gaps in the information provided. By contrast, later sources are often more comprehensive in the extent - if not the depth - of information they impart.

As to the reliability of the sources, it must be taken into account that there is considerable potential for the statistical information offered in certain documents to be inaccurate. The importance of presenting an image of progress to the world certainly was apparent in presentation of statistics to the international community. The accuracy of internal statistics and indeed reports requires some consideration, however, too. There was good reason to falsify, under- or overstate at various levels of the bureaucratic hierarchy, from the LPG right up to the State Planning Commission (Staatliche Planungskommission or SPK). Nonetheless, the administration of agriculture relied heavily on the collation of accurate statistical information: for the system to have functioned at all, there must have been some accuracy in the reporting. In most respects the statistical analyses of the problems in agriculture in the GDR (if not the actual figures) are borne out by alternative sources - such as the complaints of the farmers or villagers in Eingaben (petitions) or the mood reports of the police, Stasi as well as the SED and DBD party organisations.

With regard to the mood reports and analyses of popular opinion among farmers, there is considerable variation in the degree of scepticism which needs to be applied, depending on the time and reference points of the document. There are long lists in the files of statements of gushing support for the SED, for Walter Ulbricht as well as his successor as the leading figure in the SED regime, Erich Honecker, or for particular policies or achievements of the GDR or the Soviet Union. Many of these include quotes from farmers or LPG functionaries. I have tended to exclude such declarations of opinion as reliable sources of popular attitudes, not on the basis that no such opinions were ever expressed but on the basis that they present an artificially sanitised response to the SED regime. Many other analyses of opinions among farmers were also clearly sanitised to some extent. The coherence and complexity of arguments opposed to SED agricultural policy are often summarised in single phrases, or reduced to the catch-all notion of 'Unklarheiten' (points of uncertainty/confusion). In this respect analyses referring to specific circumstances (Eingaben, party control commission/police/Stasi investigations, individual LPG documents/party 
organisation documents) are useful in giving examples of the possible broader individual/local concerns surrounding common complaints. Analyses by state functionaries, as well as the DBD and the SED, are consistently vague in many respects. Opinions among farmers, for example, are often attributed variously to gradations of 'a few', 'some ... and others' or 'many' without the actual scale becoming entirely clear. I have found it expedient to reproduce these classifications myself, backing them where possible with statistical evidence. There was undoubtedly misreporting, intentional and unintentional, to go along with the vagueness and ideologically motivated distortion of information. Nonetheless, with due awareness of the possible flaws of individual documents, the quantity and quality of evidence available is capable of providing a reasonably comprehensive picture of the concerns of both farmers and functionaries.

Such was the wealth of as yet unexamined documentary evidence available that, owing to time constraints, I was unable to analyse as much as I would have wished the files of the complete range of agricultural institutions other than the LPGs. For the same reason, my analysis focuses too on the agricultural elements of rural society, rather than village life as a whole. These remain topics requiring further research.

\section{Contribution}

The contribution of this study to the body of literature on the history of the GDR is twofold. On the one hand, it provides an insight into the process of agricultural development in the GDR during the 1960s and 1970s at the grass roots that has been largely absent from the historiography thus far. On the other, it offers a new perspective on the longstanding debates over the relationship between state and society in the GDR, seeking to highlight the long-term processes by which the SED regime attained stability in the 1970s but was increasingly vulnerable to economic decline in the 1980s.

Since the collapse of the GDR numerous attempts have been made to characterise the dictatorship and the relationship between state and society. In the immediate aftermath of the 'velvet revolution' of 1989, the concept of totalitarianism was resurrected by many observers and despite having been abandoned as a useful analytical concept for historians for much of the previous decade, began to be reapplied to the SED dictatorship. ${ }^{41}$ The totalitarian concept appears to suit well attempts to explain how things fundamentally were, claiming to explain the complete context in which all lived experience took place. While few users 
of the totalitarian concept have not accepted that there were limits to the success of the regime's total claims on society, these claims are seen nonetheless as the benchmark against which anything meaningful can be understood about the society. ${ }^{42}$ However, while the totalitarian concept appears to explain all, in doing so it tends to leave much else unilluminated, making it a barrier against, rather than a tool for, understanding the way things 'really' were. Or rather, it explains some things better than others: since it is concerned primarily with the projects of rulers, it provides a top-down perspective on the ruled and the relationship between ruler and ruled, where other perspectives might give rise to a more differentiated picture.

Since the mid-1990s increasing numbers of historians of the GDR have found totalitarianism inadequate as a theoretical framework in which to position their research on the complex relationship between state and society. Certainly the SED regime had aspirations to total control over the population, seeking in theory to develop the socialist personality and infiltrate all aspects of society. However, recognition of these aspirations does not satisfactorily explain the variety and complexity of the relationships within and between the SED party hierarchy, the state and economic administrative apparatus and the citizens of the GDR over the forty years of its existence.

Alternative characterisations of the dictatorship have drawn upon arguably less rigidly prescriptive concepts, working outside the discourse of implied comparison with (Western) democratic rule. All too often, however, these have fundamentally replicated the top-down totalitarian perspective. ${ }^{43}$ A significant strand of arguments has sought to point out the limits of the SED dictatorship. Among others, Ralph Jessen and Richard Bessel have argued that,

looking more closely it could prove to be the case, that many of the peculiarities of east German history between 1945 and 1989 may only be explained, once there is success in describing the complicated interaction between the total claim of the dictatorship and the conditions of the environment which acted upon it - in part created by but not always controlled by the dictatorship itself. ${ }^{44}$

Not dissimilarly, Detlef Pollack has argued in opposition to the notion of an homogenous 'shut down society' ${ }^{\prime 5}$ that the limits of the SED's control were such that all attempts to homogenise society were bound to come up against barriers from within society which then shaped future policies (e.g. the hardiness of traditional structures and milieus, the formation of networks of informal relations, loss of belief in the value of progress, the counterproductive consequences of state repression). ${ }^{46}$ 
Attempts have also been made, however, to characterise the interrelations of state and society within the GDR by focusing on the practice of authority within society. The ideas of Herrschaft als sozialer Praxis ('authority as social praxis') and linked to it the notion of Eigen-Sinn (literally 'own sense or conception') have been developed in the context of the GDR in order to escape the top-down perspective by emphasising the interrelations and mutual impact of authority on society and society upon authority at the grass roots. ${ }^{47}$ The artificial distinctions of active 'rulers' and passive 'ruled', and hence the distinction between oppressive 'state' and oppressed 'society', are from this perspective complicated by the actual interdependence of dictatorial control and the individual motives and intentions, identities and self-conceptions of those on whom and through whom authority is exerted. Thomas Lindenberger's use of the term 'Eigen-Sinn' has been to illustrate the potential for people in the GDR to use and negotiate with the structures of the regime for their own interests, adapting and changing but also building and sustaining them in the process within a limited local circumstance. ${ }^{48}$

Building on these ideas, this study seeks to provide an historical analysis of the SED dictatorship, which qualifies the traditional topdown model of the functioning of authority in the dictatorship and a starkly dichotomous view of the state and society. In order to explain how the GDR functioned with regard to agriculture and rural society in practice, it is necessary to examine the internal complexity of the economic, political and administrative structures of the regime at the lower levels of the hierarchy. These structures as they operated at the grass roots over an extended period of time not only controlled and shaped the boundaries in which farmers lived and worked, but were shaped themselves by the integration and participation of people as farmers and agricultural functionaries into the system of rule. Using the example of Bezirk Erfurt I shall examine how East Germans responded to the end of private farming by resisting, manipulating but also participating in the new system of rural organisation. In addition, I shall attempt to show how LPG functionaries went about their work operating under as well as with a combination of compromise and material incentive, administrative pressure and physical force. Their relationship with and position within the communities of which they were part provides a new perspective on the interrelations of politics and society, of power, authority and changing agricultural practice in the GDR as it developed economically and technologically. Moreover, it offers some insight into the process by which SED authority, as produced and reproduced in the shifting social circumstances at the grass roots, stabilised in the rural 
communities in the GDR, yet at the same time became increasingly vulnerable to economic decline.

\section{Notes}

1. C. Ross, The East German Dictatorship, Basingstoke, 2002, p. 20: Ross also points out, however, that there are 'well founded doubts about the analytical usefulness of the term'.

2. 'Der sozialistische Frühling' or 'the Socialist Spring' was the rather euphemistic name given to the intensive agitation campaign carried out in March and April 1960 to ensure all remaining independent farmers agreed to become a member of a collective farm.

3. Staatliche Zentralverwaltung für Statistik, Bezirksstelle Erfurt, Statistisches Jahrbuch: Bezirk Erfurt, 1970, Vol. I, p. 3.

4. T. Bauer, Blockpartei und Agrarrevolution von Oben. Die DBD 1948-1963, Munich, 2003, p. 33.

5. J.- C. Kaiser, 'Klientelbildung und Formierung einer neuen politischen Kultur. Überlegungen zur Geschichte der Bodenreform in Thüringen', in Junkerland in Bauernhand, ed. A. Bauerkämper, Stuttgart, 1996, pp. 119-31.

6. M. Schwartz, 'Vetrieben in die Arbeiterschaft. "Umsiedler" als "Arbeiter" in der SBZ/DDR 1945-1952' in Arbeiter in der SBZ/DDR, eds P. Hübner and K. Tenfelde, Essen, 1999, pp. 81-128, here p. 82.

7. M. Schwartz, Vertriebene und Umsiedlerpolitik, Munich, 2004, p. 1144.

8. Ibid., p. 1146.

9. Schwartz, 'Vetrieben in die Arbeiterschaft' p. 126.

10. For information on the structure of farming in Thuringia see: G. Breitschuh et al., Thüringer Landwirtschaft zwischen 2. Weltkrieg und Wiedervereinigung, Jena, 1999; more specifically for Bezirk Erfurt: F. Augusten, Die Organisation der Rinderzucht im Bezirk Erfurt von 1945 bis 1989, Aachen, 1997.

11. B. Rauch, 'Der Bezirk Erfurt', in Die Ersten und die Zweiten Sekretäre der SED: Machtstrukturen und Herrschaftspraxis in den thüringischen Bezirken der DDR, eds H. Best and H. Mestrup, Weimar, 2003, pp. 31-39.

12. H. Mestrup, Die SED - Ideologischer Anspruch, Herrschaftspraxis und Konflikte in Bezirk Erfurt 1971-1989, Weimar, 2000, pp. 104-27.

13. This suggestion has been made with regard to the work of sociologists and anthropologists: C. Giordano, 'Die vergessenen Bauern. Agrarwissenschaften als Objekt sozialwissenschaftlicher Amnesie', in Bauerngemeinschaften im Industriezeitalter. Zur Rekonstruktion ländlicher Lebensformen, eds C. Giordano and R. Hettlage, Berlin, 1989, pp. 9-27, here p. 9.

14. W. Schütze, Investitionsfinanzierung der LPG, Berlin, 1966; W. Polsfuss, ‘Die Aufgaben der Kreislandwirtschaftsräte und ihrer Produktionsleitungen bei der Planung des wissenschaftlich-technischen Fortschritts in der Landwirtschaft', in Zum NÖS in der Landwirtschaft, eds G. Egler et al., Berlin, 1965, pp. 208-31; K. Heuer, Genossenschaftliche Demokratie als Führungsaufgabe. Rechtsfragen der Leitung der LPG und der Beziehungen zur Kooperationsgemeinschaft, Berlin, 1968. 
15. H. Grünberg, Die sozialistische Wandlung des Dorfes, Berlin, 1970; H. Hanke, Kultur und Lebensweise im sozialistischen Dorf, Berlin, 1967.

16. K. Krambach et al. (Autorenkollektiv), Genossenschaftsbauer - Verantwortung - Bewusstsein, Berlin, 1973; K. Krambach et al. (Autorenkollektiv), Wie lebt man auf dem Dorf? Soziologische Aspekte der Entwicklung des Dorfes in der DDR, Berlin, 1985.

17. U. Püschel, Unterwegs in meinen Dörfern, Rostock, 1982.

18. G. Eckart, So sehe ick die Sache - Protokolle aus der DDR. Leben im Havelländischen Obstanbaugebiet, Cologne, 1984.

19. For examples at the two ends of the period of the GDR's existence, see M. Kramer et al. (eds), Die Landwirtschaft in der sowjetischen Besatzungszone: die Entwicklung in den Jahren 1945-1955, Bonn, 1957; C. Krebs, Der Weg zur industriemässigen Organisation der Agrarproduktion in der DDR - Die Agrarpolitik der SED 1945-1960, Bonn, 1989.

20. K. Dreessen, Die Bedeutung der landwirtschaftlichen Produktionsgenossenschaften für die DDR, Tübingen, 1973; V. Bajaja, Organisation und Führung landwirtschaftlicher Grossunternehmen in der DDR, W. Berlin, 1978.

21. T. Hartmann, Die Kooperation in der sozialistischen Landwirtschaft der DDR, W. Berlin, 1971; H. Immler, Agrarpolitik in der DDR, Cologne, 1973; H.J. Thieme, Die sozialistische Agrarverfassung der DDR, Stuttgart, 1969.

22. K. Hohmann, 'Die Industrialisierung der Landwirtschaft und ihre Auswirkungen auf die Umwelt in der DDR', in Umweltschutz in beiden Teilen Deutschlands, eds M. Haendcke-Hoppe and K. Merkel, W. Berlin, 1986; see also for comment, U. Kluge, 'Die "sozialistische Landwirtschaft" als Thema wissenschaftlicher Forschung', in Zwischen Bodenreform und Kollektivierung. Vor- und Frühgeschichte der 'sozialistischen Landwirtschaft' in der SBZ/DDR vom Kriegsende bis in die fünfziger Jahre, eds U. Kluge, W. Halder and K. Schlenker, Stuttgart, 2001, p.16.

23. Kluge, 'Die Hauptschwäche westdeutscher Analysen ergab sich aus dem Mangel an nachprüfbaren Daten aus der DDR-Statistik. Die Geheimniskrämerei von SED Staats- und Parteiführung bescherte der westdeutschen DDR-Forschung ein hohes Mass an Informationsunsicherheit', in Kluge, Halder and Schlenker, p. 15.

24. For an explanation of the some of the conflicts see: T. Busse, Melken und Gemolken Werden. Die ostdeutsche Landwirtschaft nach der Wende, Berlin, 2001. For different sides of the argument see: H. Luft, 'Von der LPG zur Agrargenossenschaft: Eine positive Entwicklung?', in Die DDR war anders, eds S. Bollinger and F. Vilmar, Berlin, 2002, pp. 206-25; S. Kuntsche, 'Die Umgestaltung der Eigentumsverhältnisse und der Produktionsstruktur in der Landwirtschaft', in Ansichten zur Geschichte der DDR, Vol. 1, eds D. Keller et al., Bonn, 1993, pp. 191-211; A. Weber, 'Usachen und Folgen abnehmender Effizienz in der DDR Landwirtschaft', in Die Endzeit der DDR Wirtschaft, ed. E. Kurt, Opladen, 1989, pp. 221-69.

25. U. Kluge, 'Rezension: Blockpartei und Agrarrevolution von Oben. Die DBD 1948-1963', Zeitschrift für Agrargeschichte und Agrarsoziologie, 1(53), 2005, pp. 131-33, here p. 131: 'Keine Entwicklungsphase der DDR-Landwirtschaft ist so genau untersucht worden wie die Anfangszeit 1945/49 bis zum Abschluss der Kollektivierung in den frühen sechziger Jahren. Fast drei 
Jahrzente versinken in Vergessenheit. Nur der nie erloschene Anspruch auf Boden und Hofeigentum von Bauern, die unter dem Druck politischer Zwangsmassnahmen in den Westen geflüchtet sind, machte nach der Wiedervereinigung 1990 Schlagzeilen, die die Agrarwissenschaft aufnahm, darstellte und beurteilte.'

26. For example the contributions in A. Bauerkämper (ed.), Junkerland in Bauernhand, Stuttgart, 1996, as well as J. Osmond, 'Kontinuität und Konflikt in der Landwirtschaft der SBZ/DDR zur Zeit der Bodenreform und der Vergenossenschaftlichung, 1945-1961', in Die Grenzen der Diktatur: Staat und Gesellschaft in der DDR, eds R. Bessel and R. Jessen, Göttingen, 1996, pp. 137-69, and A. Bauerkämper, 'Die Neubauern in der SBZ/DDR 1945-1952. Bodenreform und politisch induzierter Wandel der ländlichen Gesellschaft', in Die Grenzen der Diktatur: Staat und Gesellschaft in der DDR, eds R. Bessel and R. Jessen, Göttingen, 1996, pp. 108-36, and Christel Nehrig in numerous articles: C. Nehrig, 'Industriearbeit im Dörflichen Milieu. Eine Studie zur Sozialgeschichte der Niederlausitzer Nebenerwerbsbauern 1945 bis 1965', in Niederlausitzer Industriearbeiter 1935-1970. Studien zur Sozialgeschichte, ed. P. Hübner, Berlin, 1995, pp. 167-91; C. Nehrig, ‘Das Leben auf dem Lande: Die Genossenschaften', in Leben in der DDR - Befremdlich Anders, ed. E. Badstübner, Berlin, 2000, pp. 195-218.

27. A. Bauerkämper, Ländliche Gesellschaft in der kommunistischen Diktatur: Zwangsmodernisierung und Tradition in Brandenburg 1945-1963, Weimar, 2002.

28. J. Schöne, Frühling auf dem Lande? Die Kollektivierung der DDR Landwirtschaft, Berlin, 2005.

29. Bauer, Blockpartei.

30. J. Gruhle, Ohne Gott und Sonnenschein, Nauendorf, 2000.

31. D. Langenhahn and S. Roß, 'Berfuskarrieren von Frauen', in Sozialistische Eliten. Horizontale und Vertikale Differenzierungsmuster in der DDR, ed. S. Hornbostel, Opladen, 1999, pp. 147-62.

32. T. Lindenberger, 'Der ABV als Landwirt', in Herrschaft und Eigen-Sinn in der Diktatur. Studien zur Gesellschaftsgeschichte der DDR, ed. T. Lindenberger, Cologne, 1999, pp. 167-203; C. Nehrig, 'Das Leitungspersonal der VEG 1945-1970', in Eliten im Sozialismus, Beiträge zur Sozialgeschichte der DDR, ed. P. Hübner, Cologne, 1999, pp. 309-24; P. Poutrus, Das Phänomen der Goldbroiler in der DDR, Cologne, 2002.

33. D. Berdahl, Where the World Ended, Berkeley, 1999.

34. B. Schier, Alltagsleben im 'Sozialistischen Dorf', Münster, 2001.

35. A.-M. Humm, Auf dem Weg zum sozialistischen Dorf, Göttingen, 1999.

36. 'Vorliegende Gesamtdarstellungen ... vermögen inhaltlich und methodisch nicht zu überzeugen.' These comments by Jens Schöne (citing D. Gabler, Entwicklungsetappen in der Geschichte der Landwirtschaft der DDR, Berlin, 1995), aptly describe the current historiographical situation; J. Schöne, 'Landwirtschaft und Ländliche Gesellschaft in der DDR', in Bilanz und Perspektiven der DDR-Forschung, eds R. Eppelmann, B. Faulenbach and U. Mählert, Paderborn, 2003, pp. 254-9, here p. 259.

37. C. Schneider, Was bleibt von uns? Bauernstimmen, Bautzen, 1991. Although stylised, the accounts here are nonetheless instructive on the tensions and concerns faced by LPG members during the transformation of GDR agriculture. 
38. M. Kipping, Die Bauern in Oberwiera: Landwirtschaft im Sächsisch-Thüringischen 1945 bis 1990, Beucha, 2000.

39. Breitschuh et al., Thüringer Landwirtschaft.

40. D. Langenhahn, 'Machtbildung und forcierter Strukturwandel in der Landwirtschaft der DDR der 1970er Jahre', in Zeitschrift für Agrargeschichte und Agrarsoziologie, 2, 2003, pp. 47-56; D. Langenhahn, 'Auf dem Weg zur genossenschaftlichen Demokratie?', in Der Schein der Stabilität. DDR Betriebsalltag in der Ara Honecker, eds R. Hürtgen and T. Reichel, Berlin, 2001, pp. 263-74; Nehrig, 'Das Leben auf dem Lande', pp. 195-218.

41. K. Schroeder, Geschichte und Transformation des SED-Staates, Berlin, 1994.

42. I-S Kowalczuk, Legitimation eines neuen Staates, Berlin, 1997, p. 345. As L.H. McFalls has written, 'theories of communism's evolution and revolutionary end have, in fact, merely elaborated on one or more of the three possible sources of change that the classic theories of totalitarianism identified: international competition, ideological and institutional erosion and corruption, or societal resistance.' L.H. McFalls, Communism's Collapse, Democracy's Demise, London, 1995, p. 6.

43. For example Konrad Jarausch's description of the GDR as a modern welfare dictatorship in K. Jarausch, 'Care and Coercion: the GDR as Welfare Dictatorship', in Dictatorship as Experience: Towards a Socio-Cultural History of the GDR, ed. K. Jarausch, Oxford, 1999, pp. 47-69.

44. R. Bessel and R. Jessen, 'Einleitung: Die Grenzen der Diktatur', in Die Grenzen der Diktatur: Staat und Gesellschaft in der DDR, eds R. Bessel and R. Jessen, Göttingen, 1996, pp. 7-23, here p. 9.

45. Sigrid Meuschel argued that the GDR was a 'stillgelegte Gesellschaft', suggesting that the totalitarian expansion of the state resulted in a dying away of society. S. Meuschel, Legitimation und Parteiherrschaft in der DDR, Zum Paradox von Stabilität und Revolution in der DDR, Frankfurt am Main, 1992;

S. Meuschel, 'Uberlegungen zu einer Herrschafts- und Gesellschaftsgeschichte der DDR', Geschichte und Gesellschaft, 19, 1993, pp. 5-14.

46. D. Pollack, 'Die Konstitutive Widersprüchlichkeit der DDR', Geschichte und Gesellschaft, 24, 1998, pp. 110-31.

47. Both terms were originally used by Alf Lüdtke in other contexts: A. Lüdtke, 'Einleitung: Herrschaft als soziale Praxis', in Herrschaft als Soziale Praxis. Historische und sozial-anthropologische Studien, ed. A. Lüdtke, Göttingen, 1991, pp. 9-63; A. Lüdtke, Eigen-Sinn, Fabrikalltag, Arbeitererfahrungen und Politik vom Kaiserreich bis in den Faschismus. Ergebnisse, Hamburg, 1993. But they have since been used in the context of the GDR, most notably by Thomas Lindenberger: T. Lindenberger, 'Der ABV als Landwirt', in Herrschaft und Eigen-Sinn in der Diktatur. Studien zur Gesellschaftsgeschichte der DDR, ed. T. Lindenberger, Cologne, 1999, pp. 167-203; T. Lindenberger, 'Herrschaft und Eigen-Sinn in der Diktatur. Das Alltagsleben der DDR und sein Platz in der Erinnerungskultur des vereinigten Deutschlands', Aus Politik und Zeitgeschichte, B40, 2000, pp. 5-12; T. Lindenberger, Volkspolizei: Herrschaftspraxis und öffentliche Ordnung im SED Staat, 1952-1968, Cologne, 2003.

48. T. Lindenberger, 'Die Diktatur der Grenzen. Zur Einleitung', in Herrschaft und Eigen-Sinn in der Diktatur. Studien zur Gesellschaftsgeschichte der DDR, ed. T. Lindenberger, Cologne, 1999, pp. 13-44. 
PART I fo

Consolidation and Control:

Collectivisation ANd Its Malcontents 


\section{어 1}

\section{Steps towards Full Collectivisation of Agriculture}

There was once the Kaiser's empire, there was once Hitler's empire and yet everything changed again. We just want to hold on and wait for what's going on next year! ${ }^{1}$

(One of the farmers' arguments against joining the LPG when faced with an agitation brigade in the vicinity of Görmar, Kreis Mühlhausen in December 1959.)

There is no doubt that despite claiming the title of 'the workers' and peasants' state' in 1949, it was the former not the latter who were central to the identity of the GDR as both carriers of the revolution and models of the socialist personality. The extent and depth to which the SED had penetrated rural society was correspondingly limited. The advancement of collective farming during the 1950s was in large part the beginnings of an attempt to remedy this glaring deficiency. The completion of the collectivisation campaign in 1960, while being an administrative success, revealed, however, just how deficient the permanent structures of control and communication between the SED leadership and rural communities were and how little certainty there was in the countryside of a future under the SED.

During the 1950s, the campaign for collectivisation of agriculture sought to undertake the most radical transformation of the conditions of rural existence since the land reforms. It entailed a massive mobilisation of the regime's apparatus for publicising its policies, persuading people of their value and suppressing hostility. In so doing it placed the effectiveness of the local, district and regional administration of agriculture and rural communities under close scrutiny, exposing the extent and limitations of this apparatus. At the same time, with the formation of the new LPGs, collectivisation forced farmers and local functionaries to accept new roles and responsibilities and in so doing began to change the basis on which the SED regime communicated with and transmitted its authority to farmers and rural communities at large. The manner of the campaign, which caused in the short term such fear, anger and hostility towards the SED, had long-term consequences, setting 
the parameters within which future policies were conceived, communicated and received in the next decade and beyond.

\section{The Campaign for Collectivisation}

The pace of the SED-directed transformation of society since the end of the war had been far slower in the countryside than it had been in the towns for a number of reasons. The central role of the church in village life, the complex networks of familial relations in the village, the lack of anonymity and the essential interdependency of the inhabitants of small communities were important factors in preserving the established social order. Moreover, the simple geographical isolation of many communities meant the ideological as well as purely organisational capacity for change in the villages was lacking.

By the early 1950s the self-confidence of the SED leadership under Walter Ulbricht had risen sufficiently that it was willing to place more pressure on the population in the implementation of the socialist transformation of society and increased norms of production. At the II SED Party Congress in 1952, the phase 'the construction of socialism' (Aufbau des Sozialismus) was announced and the SED thus began the next step in its socioeconomic transformation of the countryside following the land reforms of the postwar period. Having parcelled out the larger estates in the late 1940s, the goal was now to re-establish large-scale production units through the amalgamation of farms into socialist collectives organised according to a uniform pattern. Where before organised cooperation between farmers had been quashed by the SED, material and practical support (and with it state interference) was now given to the 'spontaneous' formation of farming collectives in some selected villages and the SED leadership advanced a campaign for the formation of agricultural collectives more widely, despite the lack of suitable conditions for widespread large-scale collective production. ${ }^{2}$

Although aspects of the Soviet model were adopted during the drive for collectivisation, this was by no means to be a simple Sovietisation of agriculture: the land brought into the collective remained legally, albeit with numerous restrictions, in the ownership of the farmer, while the range of types of collective farm organisation enabled farmers to maintain, if they chose, individual control of livestock and/or farm machinery. ${ }^{3}$ In the LPG Type I only the use of the land was managed in common; in Type II (which relatively few farmers ever adopted) the land, tools and machinery were to be held collectively; and in Type III the livestock were also included. The majority of farmers, however, continued 
to resist collectivisation even as the state offered greater incentives to those who would join - through privileged access to machinery, seed and fertiliser, lifting of debts and extension of credit - and more severe sanctions to those who would not or could not: high taxes and the setting of impossibly high production quotas, which effectively meant jail terms and the confiscation of property as punishment for alleged sabotage. Under such duress a large proportion of Großbauern (wealthy farmers: defined as those owning 20 hectares of land or involved in capitalist enterprise) chose flight from the GDR or abandoned their farms during the course of 1952 and 1953, which in turn exacerbated deficiencies in the supply of food to the population. ${ }^{4}$

In the towns, the ultimate results of the more hard-line policies of the Aufbau des Sozialismus and the increased production norms were the demonstrations of 17 June 1953. Despite great opposition to the beginnings of a campaign for collectivisation and punitively high production quotas along with false charges of economic sabotage for non-compliant farmers, participation in the uprisings remained limited in the countryside, though not for want of disgruntlement with the state's policies. Notable exceptions in Bezirk Erfurt were demonstrations and open opposition to the SED led in part by village pastors in Bad Tennstedt, Kreis Langensalza and in Eckolstädt, Kreis Apolda, in the latter's case ending only with the deployment of Soviet tanks. In Bezirk Erfurt, private farmers were involved too in demonstrations on 17 June in four (out of thirteen) district capitals during which some of those imprisoned during the 'class struggle' in the countryside were forcibly released. The most notable of these actions occurred in Mühlhausen, where 5,000-6,000 farmers who had been attending a farmers' assembly in Oberdorla on 17 June marched through the town and occupied the court buildings, demanding the return of a free market and the release of imprisoned farmers. ${ }^{5}$ The date 17 June, however, while gaining symbolic value - and it continued to be referred to by disgruntled farmers in the Bezirk in subsequent years ${ }^{6}$ - was not directly experienced by the vast majority of the rural population. Rather, in subsequent months, as the SED implemented the 'New Course' designed to defuse the most serious causes of dissatisfaction among East Germans, farmers took the opportunity to reassert themselves and reverse measures forced upon them. Thus LPGs formed under duress disbanded and farmers withdrew to harvest independently during 1953. By the following year, however, pressure and material incentives were again being brought to bear on farmers and farm labourers to form and re-form collective farms.

For much of the 1950s an uneasy situation developed in rural communities. Many LPGs remained economically unstable, lacking both 
the quality of land and livestock and the degree of expertise, dedication and social cohesion among members to function efficiently. ${ }^{7}$ Private farmers faced with punitive production quotas found themselves unable to continue in agriculture and, in some cases fearing draconian punishments, abandoned the GDR altogether. While it is clear that the majority of private farmers in the GDR managed to survive and in many cases even profit from the system of production quotas and 'freie Spitzen' ('free peaks': i.e. excess production beyond the state quota for which the state was willing to pay a higher price), a basic antagonism remained between much of the rural population and the representatives of the SED regime, demonstrated repeatedly in minor acts of resistance. In June 1957 farmers in Kreis Apolda were reported to have called openly for the return of the free market and the abolition of quotas. ${ }^{8}$ Minor acts of sabotage also took place to undermine existing collective farms. In early 1958 in an LPG in Kreis Mühlhausen, for example, several pigs were reported to have been stabbed. The strength of opposition to the LPG in the village also meant that those who joined could be seen as traitors and thus faced social isolation. Various incidents were reported in which LPG members were insulted and their children bullied. In a case in a village in Kreis Gotha, a woman was reportedly spat at while in the village shop for having become a member of the LPG. ${ }^{9}$

Paradoxically, more serious for the regime than these episodes of 'class conflict' was the lack of any confrontations whatsoever with the 'class enemy' in some rural communities during the later 1950s. Village SED party secretaries, local mayors and police constables as well as representatives of the various mass organisations were widely and repeatedly criticised for the leniency of their approach to the class situation in the communities for which they were supposedly the responsible officials of the socialist state. There was widespread reluctance among such local functionaries to campaign against or denounce those farmers whose relative wealth and inherited status in the village marked them out - on paper at least - as the 'class enemy'. At the same time, local functionaries were criticised for the lack of effort they put into promoting potentially controversial policies. Local mayors and village councillors, particularly where they were not themselves members of the SED, showed themselves to be less than enthusiastic in support of collectivisation for most of the 1950s.

Independent farmers formed a large part of the membership of the bloc parties in rural constituencies - particularly the farmers' party (Demokratische Bauernpartei Deutschlands or DBD) but also the CDU (Christlich-Demokratische Union) and in certain areas the liberal party (Liberal-Demokratische Partei Deutschlands or LDPD). Consequently there 
was considerable pressure on local officials from within their own local party groups at the very least to avoid confronting unpopular issues such as collectivisation. Even if they did not make any arguments against collective farming in principle, mayors and village councillors expressed strong reservations against its implementation in practice in the particular circumstances of their locality. Similarly the chairmen of the local boards of the state-run Farmers' Mutual Aid Union (Verein der gegenseitigen Bauernhilfe or $\mathrm{VdgB}$ ) were known to drag their feet when called upon to persuade farmers of the benefits of the LPG. Rather they tended to sympathise with the unwillingness of particularly smaller farmers and Neubauern to give up individual use of the farms that they had so laboriously established since the end of the war. ${ }^{10}$ Even the tractor drivers of the Machine and Tractor Stations (Maschinen-TraktorenStationen or MTS) were not necessarily reliable. Manned in part by workers recruited from industry, the MTS were in theory to function as progressive proletarian bulwarks in the otherwise ideologically backward countryside, casting their influence over several surrounding villages. It was clear, however, that in a number of cases the MTS workers showing a lack of 'class consciousness' - enjoyed better relations with independent farmers than with the chairmen of the LPG. ${ }^{11}$

The continuing importance of the church as an alternative source of authority in the village was part of the problem as far as the SED leadership was concerned. That clergy were occasionally seen to be active in warning against the LPG was considered a serious obstacle to persuading all those in the rural community to consider collective farming seriously. ${ }^{12}$ Belief in the prospect of reunification with West Germany in the none too distant future gave people the confidence to retain openly their links with the church despite the atheism of the SED regime. There remained, too, a strong commitment to the local pastor as a central and long-standing figure of rural life - one who had in many cases played a vital role in representing the interests of the community during the end of the war and the hardships and injustices of the Soviet occupation and early years of SED rule. ${ }^{13}$ Thus, in the villages, adherence to the church and respect for the opinions of the pastor - whether Catholic, Lutheran or Reformed Protestant - remained strong during the 1950s, even as the state began to win battles over religious education and the state youth confirmation ceremony (Jugendweihe). ${ }^{14}$ Meanwhile, local representatives of the state were not always sufficiently motivated by zeal for the socialist cause to condemn the continuing willingness of villagers to work on the local church board and support even a controversial local pastor. Investigations into rural policing in a number of districts in the Bezirk at the end of 1957 found that strong connections 
with one or other of the Christian churches had impaired the effectiveness of village police officers and SED party organisations. ${ }^{15}$

During the 1950s the pressure on farmers to commit themselves to joining or forming an LPG was by no means applied comprehensively in the GDR, or even in Bezirk Erfurt, with a consistent degree of urgency or with a consistent set of methods and arguments. It is in the context of this inconsistency that the behaviour and actions of private and collective farmers and the various participants in the regime's apparatus for agitation, when the drive for full collectivisation of agriculture began, need to be understood.

The confusion of the situation established in 1960 with the rapid completion, on paper, of full collectivisation was born out of the variety of attitudes among both farmers and agitators as to what should or would be created by collectivisation in practice, and what would be or should be preserved of the structures and practices of independent farming and private ownership. Collectivisation took place in an atmosphere of uncertainty with regard to the future organisation of agriculture, leaving a lasting element of unpredictability as to the status and future of the LPG.

In line with the 'New Course' introduced by the SED leadership in 1953, a set of administrative and economic incentives and pressures had replaced the crude threats of imprisonment and confiscation which had been used to force collectivisation prior to the popular unrest across the GDR in June of that year. Although from 1954 onwards the number of LPGs, the proportion of land farmed collectively and the number of LPG members in Bezirk Erfurt increased, this was a gradual process, driven less by the successful persuasion of independent farmers or landowners, than by the abandonment of land and the recruitment of industrial workers or landless labourers to the collective farms. It was not until 1958 that the rate of formation of new collectives increased significantly, with the participation of formerly independent farmers. The decision taken at the 33rd Session of the SED's Central Committee (Zentralkomitee or ZK) in the autumn of the previous year to step up the campaign for collectivisation led to attempts at LPG recruitment aimed primarily at those private farmers who were politically organised in either a party or a mass organisation. ${ }^{16}$ From the middle of 1958, at the V SED Party Congress, the focus of the campaign was expanded to encompass all private farmers, including those so-called 'Großbauern' who had previously been prevented from forming or joining LPGs. ${ }^{17}$ Nevertheless during the course of that year the amount of land in the Bezirk farmed collectively reached only 17.7 per cent. ${ }^{18}$ The vast majority of independent farmers felt themselves able to resist the LPG and the agitators for the time being, if not for ever. 


\section{Popular Responses to Collectivisation}

Opposition to the formation of collective farms was based on a number of objections, not least unwillingness on the part of traditionally independent farmers to lose private control over their own finances. ${ }^{19}$ The effectiveness of economic levers such as high delivery quotas to encourage collectivisation had been balanced out by the incentives for making as much production available as possible for purchase by the state. Successful farmers could certainly double their incomes through the sale of excess produce bought up by the state at higher prices. The prospect of such forms of additional income being restricted as a result of membership in a collective was a strong disincentive for joining. From a purely practical point of view the parlous state of many of the collectives in existence did little to persuade farmers of the value of collective farming either. Although the financial situation of the LPGs did gradually improve over the years, at the end of 195950 per cent of Type III LPGs in the Bezirk were nonetheless officially categorised as 'financially weak' ${ }^{20}$ A minority of elite LPGs were able to pay high wages and easily exceed their plans. Others managed to get by with some success, taking advantage of the preferential treatment given to LPGs in terms of reduced quotas and access to machinery and fertiliser. The majority, however, lagged behind. All too often inefficiency, poor work organisation and a lack of commitment to the LPG from its members compounded natural obstacles to improved production levels. The lack of financial success in LPGs inevitably led in some cases to a sour atmosphere among the members. Certainly personal conflicts between members of an LPG put private farmers off joining collective farms. It was enough to live in close proximity to one another without having to work together as well. A report on the problems facing agitators operating in an MTS area in Kreis Mühlhausen in December 1959 described the situation in one village thus: 'no one wants to join the existing LPG in Diedorf because there are always conflicts and people say: "we're not getting involved in that mess"'. ${ }^{21}$

A report by a Stasi informant on the LPG Type II in Wahlhausen, Kreis Heiligenstadt in November 1958 underlines the mutual antagonism felt between private farmers and the LPG. As a private farmer himself, he reported on the anger among farmers who were constantly being called upon to pick their fields again for more potatoes even though they had fulfilled their quotas. In contrast, he pointed out that the LPG had actually allowed potatoes to go to waste in its own fields. This and other incidences of shoddy practice or mismanagement of the LPG had hardened his attitude against the actual prospect of joining this collective. ${ }^{22}$ In a further report the informant noted that a leading 
figure in the LPG had openly proposed that remaining private farmers should be treated more severely in order to make them enter the collective. ${ }^{23}$ For many farmers, the LPG represented nothing so much as being forced into the hands of those who would destroy them.

In the late 1950s the prospect of joining one such LPG did not appeal to either the economic or the social interests of farmers. Rather the LPG was seen at best as a last resort for those unable any longer to run their farms profitably. ${ }^{24}$ LPGs founded prior to the intensified agitation campaigns of 1960 were thus seldom formed by the most successful and experienced farmers. ${ }^{25}$ Rather, the membership of the LPGs tended to consist of industrial workers, landless farm labourers and small farmers who lacked the wherewithal to run a large enterprise effectively. Some of the more severe cases came under the scrutiny of the District Party Control Commission of the SED (Kreisparteikontrollkommission or KPKK). For example, the KPKK carried out an investigation into the LPG Type III in Kindelbrück in 1958, which had been formed largely from abandoned land left in the inexpert care of the village council (Rat der Gemeinde or RdG). The members of the LPG were exclusively former agricultural labourers and thus while not new to agriculture, had no experience between them of running a farm as a whole. No less significantly, they had little livestock or draft animals let alone machinery with which to work on fields that had been allowed to grow thick with weeds. State subsidies were thus absolutely vital over a number of years to enable the LPG to construct a collective livestock shed. Even with this support, however, members were scarcely able to raise enough profits to give themselves sufficient income, causing serious disgruntlement with the whole project of collective farming. ${ }^{26}$

Even as the drive towards full collectivisation was picking up speed, previously formed LPGs began to implode, unable to give their members a sufficient income to live on. In the LPG Type I Grossmonra, Kreis Sömmerda nineteen members of the LPG resigned, sending official notice to the LPG board, some of whom (to the outrage of the KPKK) even consulted a lawyer. In addition the SED party secretary in the LPG made clear his intention to hand in his party document. Of the nineteen, thirteen were ultimately persuaded to return to the LPG by the district state authorities, two were denied the chance to rejoin the LPG and four were allowed to remain uncollectivised. ${ }^{27}$

Lacking the means to employ a sufficient workforce or children who would run the farm, older farmers often found no other way to cope with the oppressive demands placed upon them by the state than by forming or joining an LPG. Here the question of access to machinery was in many cases decisive. From the beginning of 1958 the MTS were di- 
rected to serve primarily the LPGs rather than allow their machinery to be rented by private farmers. In practice this did not occur everywhere, with MTS workers often preferring, whether out of conviction or financial incentive, to continue to serve private farmers (in some cases to the detriment of the LPGs). ${ }^{28}$ It was easier, for example, for an MTS worker to fulfil his quota of fields harvested or ploughed if he did not have to move his tractor to a different valley halfway through the day. However, the preference given to the LPGs on the whole in terms of access to new machinery (reinforced by the decision announced at the 6th LPG Conference in February 1959 that at first only LPG Type IIIs in fully collectivised villages with over 500 hectares should receive the machinery of the MTS on long-term loan) encouraged private farmers to join up. ${ }^{29}$ Faced with the possibility of being denied access to machinery and with too little money to purchase their own, some of the less wealthy farmers were moved to join or form LPGs. However, this did little to change the image of the agricultural collectives among the more successful independent farmers as being the last resort for the desperate.

At this stage the attainment of full collectivisation remained remote for all concerned. If some independent farmers expected German reunification, a third world war or the state's financial dire straits to intervene before collectivisation was completed, as far as the SED leadership was concerned, full collectivisation would not be possible for several years yet either. The State Planning Commission had initially decided on 1963 and then 1965 as attainable deadlines for full collectivisation. ${ }^{30}$ Given the potential damage to the economy and to the ability of the GDR to supply itself with food at a time when the SED leadership explicitly sought to demonstrate superior living standards in comparison with the Federal Republic, progress in the formation of LPGs remained gradual and incremental. Successful private farmers were well aware of the weakness of the LPGs and their own importance to the maintenance of production levels and dismissed the prospect of collectivisation accordingly. Functionaries throughout the administration of agriculture and the government of rural communities were aware of this too, and were reluctant to agitate for collectivisation when farmers remained so clearly opposed to it. Even the most dedicated to the socialist cause or the class conflict were wary of compromising the supply of food to the population.

\section{The Limits of Local Agitation}

In Bezirk Erfurt the rate of collectivisation in 1959 had sunk below that of the previous year, with a total of fifty-nine new LPGs founded that 
added only a further 4.9 per cent of the agricultural land in the Bezirk to the amount farmed in collectives. This slow progress was put down, quite simply, to the unwillingness of independent farmers to join the LPGs. Nevertheless it was also clear that at a local level not enough was being done to win them over. Old antagonisms had led existing LPGs to refuse to accept new members from among those who had long rejected the collective. More generally, consensus had by no means been achieved as to whether collectivisation could or should be achieved in the near future among the functionaries of those local institutions on which the SED leadership relied to exert its influence over farmers from the village SED organisation, the bloc party groups, the mass organisations as well as the village and district state administration, the MTS and any nearby factories.

Assessments of opinion in SED organisations in the countryside uncovered a number of individual SED members, party secretaries as well as entire party organisations who were unsupportive of the current progress of collectivisation. Given the lack of SED members among the farming population, the local organisations of the Farmers' Mutual Aid Union $(\mathrm{VdgB})$ provided a network through which the regime sought to exert its influence on private farmers and rural communities in general. However, it was widely recognised that local VdgB organisations could not always be relied upon to espouse the party line with regard to agriculture, particularly on such a divisive issue as full collectivisation. In January and February 1960, the Stasi Bezirk administration sought to rectify this by instructing their district offices to see that those farmers standing for election to local $\mathrm{VdgB}$ governing boards were politically and ideologically suitable. ${ }^{31}$ Regardless of these instructions, it was clear in early 1960 that in the majority of villages, the local VdgB organisations could not be relied upon to act in accordance with SED policy. ${ }^{32}$ In March 1960 at least twenty-six chairmen of local VdgB organisations in Kreis Arnstadt were dismissed from their posts for failing to support 'the socialist transformation of agriculture' ${ }^{33}$

The unreliability of those charged with driving forward the collectivisation process on the ground is in many respects wholly explicable given the choices with which they were faced. Up until 1960, unless one believed in the importance of collectivisation in itself, there was little reason actively to campaign on its behalf. Joining an LPG had not been made obligatory by law, most farmers opposed the idea and the potential for success was limited by the ease with which rural communities could close ranks against the small numbers of activists who were prepared to advocate the policies of the SED regime. The secretary of the SED organisation and pub landlord in a village in Kreis Mühlhausen 
explained his inaction quite simply, with the reasoning that if he were to make his support for socialism known - 'no one will drink a glass of beer in his pub anymore' ${ }^{34}$ The difficulty of winning over farmers was particularly acute in those communities where the church and religion still played a major role in the attitudes of the community as a whole to the latest moves by the SED. In the Eichsfeld districts based around the small towns of Worbis and Heiligenstadt, where Catholicism predominated, the functionaries charged with advocating collectivisation tended either to lack the conviction themselves or simply had insufficient authority within the community to make a convincing case..$^{35}$ Consequently almost no progress was made in the development of LPGs here. In districts where the Reformed Protestant Church predominated, pastors in a number of villages undermined potential support for the LPG by speaking out against collectivisation. Their views were not opposed even by the functionaries of local government and members of the SED and bloc parties who themselves had in some cases remained practising Christians. ${ }^{36}$ Given the resolve of farmers and rural communities to resist collectivisation, and the lack of resolve among rural functionaries to campaign for it, there appeared in most villages to be no coordinated or coherent strategy for overcoming opposition to full collectivisation.

After a difficult harvest in 1959 across the GDR owing to a long period without rain and even greater need for rapid increases in production in order to keep pace with higher consumption levels, it was clear to the SED leadership that more would have to be done quickly to achieve a leap forward in productivity. Despite the intention to create at least one LPG in every village by the end of 1959, on 31 December, 114 separate communities were recorded in Bezirk Erfurt without any LPGs at all, while in other parts of the country there had been even less success ${ }^{37}$ The replacement of Erich Mückenberger as Agriculture Secretary in the Central Committee by Gerhard Grüneberg ${ }^{38}$ during the seventh session of the Central Committee in December 1959 signalled a change to a higher-risk policy of rapid collectivisation despite the short-term economic shortfalls this was likely to inflict. ${ }^{39}$ Brigades of agitators had already been deployed around the Bezirk charged with persuading farmers to form LPGs, establishing bridgeheads from which to move the campaign in the districts forward. However, their impact on farmers remained limited. With relatively few qualified personnel available to staff the brigades, the amount of time each brigade was able to spend in a single village was not limitless. Farmers who had no desire to join an LPG could thus effectively resist outside interference by weathering the storm and awaiting the brigade's departure. The strategy of rely- 
ing on the propaganda impact of the media, the persuasive efforts of village functionaries and the deployment of occasional brigades of agitators alongside the usual tactics of economic pressure and incentive lacked the required level of 'continuous confrontation'. The SED Central Committee thus charged the SED Bezirksleitungen with developing a programme of intensive campaigns in the villages.

\section{The Campaign Intensified}

Thus far the basic weakness of the SED's influence over the rural population and the basic unreliability of the network of functionaries operating at a district and local level in agriculture and rural society had been all too clearly demonstrated. At the same time, many farmers had exposed themselves as opponents of the socialist regime who were willing to resist as far as they could any change in the organisation of agriculture. As such they appeared too to be forces of reaction standing in the way of the social transformation of rural society. Seen in these terms, the value to the SED regime of a more rigorous approach towards resistant farmers was clear. A campaign which mobilised large numbers of supporters of SED policy and placed rural and agricultural functionaries under close scrutiny would be a telling reminder of the SED leadership's strength as well as a useful means of testing loyalty and exposing opposition in the countryside. The move then in early 1960 to accelerate the process and race towards full collectivisation, even if decided much in advance by the SED leadership, was met with considerable trepidation by functionaries operating in rural communities themselves and at lower levels in the administration of agriculture. At the same time, farmers were shocked by the virulence with which they were being 'persuaded' to join or form LPGs, prompting equally radical responses, not least of which was flight westwards to the Federal Republic.

From the end of January 1960 the number of brigades of agitators arguing for collectivisation in the villages was greatly increased. The personnel of the brigades was made up of politically reliable citizens drawn from a number of urban and rural institutions: staff and students from universities and polytechnics, MTS and State Owned Farm (Volkseigenes Gut or VEG) officials as well as functionaries of all political parties and mass organisations were called upon to promote the 'socialist transformation' of the countryside. Once these had been briefed on the arguments in favour of collectivisation and the benefits of the LPG, they were sent into the countryside to liaise with local functionaries and party members, visit farmers in their homes and arrange public 
meetings, staying in a single rural community for a number of days if necessary.

The success of these brigades varied according to their own competence, leadership and organisation as well as the receptiveness of the communities they entered. The poor behaviour of certain brigade members and the lack of technical agricultural knowledge of urban students and functionaries certainly aggravated the resistance among villagers, who resented being bullied by what they saw as a group of ignorant 'townies' into acting against their will and common sense. ${ }^{40}$ With agitation brigades staying for days at a time in the villages, local functionaries were given the task of ensuring they were provided with food and accommodation, as well as the requisite information about the locality. While the brigades appear in most cases to have received sufficient support, the work of the brigades was hampered in some cases by either the incompetence or the hostility of local officials. For example, in Niedersynstedt, in Kreis Weimar, the accommodation provided had been locked when the brigade arrived and the members of the one existing LPG in the village refused to let any brigade members stay in their houses. In another instance in Kreis Weimar, the deputy mayor responded to the claim by members of the agitation brigade that they intended to remain as long as it would take for them to achieve their goal, with the disparaging remark: 'Let's see who's going to last longer. ${ }^{\prime 4}$

Nevertheless some brigades were able to make an impact in the villages, especially if they had been effectively briefed with information on the local circumstances - a task that largely fell to the local police officer (Abschnittsbevollmächtigter or ABV). Despite broad resistance to the idea of collectivisation, invariably some village inhabitants saw the advantages of the collective farm, not least if they were at a disadvantage in the existing social structure. The brigades thus sought to make use of potential splits between generations, contrasting the low wages of a family member on a private farm with possible earnings in the collective. Similarly they sought to highlight the freedom of small landholders, particularly single women, from obligation to the larger farmers in the village which supposedly the collective would bring. Attention was also focused on the wives of private farmers. ${ }^{42}$ The alleviation of their heavy workload in the fields and in the home which the LPG promised to provide, as well as the opportunity to gain qualifications, certainly appealed to some women, (although many farmers' wives remained among the staunchest of opponents to the LPG). ${ }^{43}$

In the village of Wandersleben in Kreis Gotha, the prospects for a successful collectivisation were quite good. Much of the farming com- 
munity had benefited from socialist policy in rural areas over the years. Four hundred hectares had been made available during the land reforms in the late 1940s, an LPG Type III had been in existence since 1952 and had managed to raise its grain production levels higher even than the average in West Germany. Furthermore it was claimed that the LPG's mastery of maize production in accordance with a much-disputed SED policy had enabled it to avoid the feed problems suffered by many other farms. Meanwhile Wandersleben itself had developed into a local centre of commerce as well as education with an expanded school population and the establishment of an agricultural vocational school. Within the village there were organisations of the SED, CDU and DBD as well as the major mass organisations - the Free German Youth (Freie Deutsche Jugend or FDJ), the Democratic Women's Union (Demokratischer Frauenbund Deutschlands or DFD) and the Free German Trade Union Association (Freier Deutscher Gewerkschaftsbund or FDGB). The regime was also represented in local sport in the Society for Sport and Technology (Gesellschaft für Sport und Technik or GST) and the German Athletics and Sports Union (Deutscher Turn- und Sportbund or DTSB); and in care for the elderly with the People's Solidarity Organisation (Volkssolidarität). Private farmers, too, were organised in a local organisation of the $\mathrm{VdgB}$, though the lack of a chairman rendered the organisation ineffective. Importantly the state village assembly contained a mixture of collective and private farmers as well as industrial workers.

Nonetheless, by the end of 1959, 50 per cent of farmers based around Wandersleben had still not been persuaded to join or form an LPG. Some private farmers who had high yields from livestock production producing double their state quotas - expected collectivisation to cut their profits. Others claimed simply: 'At the end of the day, I don't want to become an estate farm labourer.' In order to bolster the impetus of the campaign, a brigade of agitators organised by the Bezirk committee of the National Front - with representatives from the SED's district administration (Kreisleitung), the District State Council (Rat des Kreises or RdK) and the VdgB and CDU district leaderships - joined members of the local committee to canvass support across all the sections of the community in the village. Railway workers, many of whom owned and farmed small plots but were exempt from delivery quotas, were to be persuaded to get involved with the LPG or at least lease their land to the collective. Christian leaders and young people were targeted to persuade them to participate in the campaign for collectivisation, while visits were organised to see a functioning LPG and to view Soviet technology in action. In addition the members of the brigade were armed 
with information on how much each private farmer was profiting from their current state quotas in order to shame people for exploiting the system. ${ }^{44}$

In Wandersleben, as elsewhere in the Bezirk, the initial progress of these campaigns was nevertheless still tortuously slow. Farmers who had resisted collectivisation thus far continued with the usual methods of weathering the storm. They avoided entering into conversation with the brigades by shutting doors, disappearing into the fields, and avoiding or keeping quiet at public meetings. ${ }^{45}$ Where they could be brought to talk, farmers were careful to raise arguments with which they sought to put off agitators without necessarily exposing themselves to accusations of opposition to socialism. One farmer in Oberdorla, Kreis Mühlhausen called for the immediate implementation of communism rather than just socialism - claiming that just as the workers were given complete factories, so would he enter the LPG once the state had built the new livestock sheds. Another pointed out that private farmers still existed in the Soviet Union, so why not allow them here. More widely, private farmers argued that they would produce more if they were allowed to continue to farm individually but received the same financial support as the LPG, enabling them better to do their duty to socialism in fulfilling the seven-year plan. Alternatively, they agreed to the principle of the LPG, deferring their entry, however, until they had passed on the farm to the next generation, the harvest had been brought in or at the very least until relatives or certain other prominent figures in the community had agreed to join as well. ${ }^{46}$

Others more honestly said that they would only join when they had no other choice, but not until then. In the village of Hollenbach, for example, the wife of an independent farmer told the brigade that her husband was out and refused to let them into the house. In the ensuing discussion she then stated: 'We are still doing well, and we want to keep our independence ... if the water's up to our necks, then we'll go into the LPG.' Similarly other farmers made it clear that they would not join voluntarily, but would do so only if they were forced to join or if it were made illegal not to do so. ${ }^{47}$ The principle of voluntary entry into the LPG enshrined in the model statutes was a key grievance of farmers, who felt the humiliation of 'giving up' the farms of their forefathers far more keenly as a result of this clause. Resistance in a number of villages continued thus to be broad and resolute, and with rumours circulating that an international summit meeting in Paris in May of that year would 'change everything', many decided to try to hold out until the direction of the political tide was certain. ${ }^{48}$ 


\section{The 'Socialist Spring'}

The SED's response to ongoing resistance and the lack of any very significant rise in the percentage of land in the collectives by March, was to increase the intensity of the campaigns still further. Following a meeting between the first secretaries of the SED Bezirksleitungen at the ZK to discuss agricultural questions on 11 March 1960, the Bezirksleitung passed a resolution laying out the initial steps towards mobilising forces loyal to the regime throughout the countryside. Meetings were to be held between the Bezirksleitung, the SED district first secretaries and the agricultural functionaries in the Rat des Bezirks. All the heads of the bloc parties, the mass organisations and other Bezirk-wide institutions were to meet to agree a common strategy with regard to collectivisation, and in all the districts conferences were to be held in the course of the week which all responsible functionaries, mayors and chairmen of district institutions were to attend. The numbers of agitators in the brigades operating in the Bezirk rose to as many as 9,724 on 26 March drawing on factory workers and employees from other enterprises to bolster numbers. ${ }^{49}$

Such intimidating and constant pressure soon began to have results. With attention focused on the lead farmers in each community to form the collective, others soon joined, unwilling to resist unaided and to some extent reassured of the economic viability of the LPGs. Reports on the efforts of a brigade operating in early March in the small agricultural town of Kindelbrück in Kreis Sömmerda illustrate some of the methods employed. Over the week from 3 to 11 March 1960 the sixteen members of the agitation brigade were to divide into five groups each concentrating on a single farm. During the course of the week, members of the board of the existing LPGs, the MTS and two neighbouring state-owned farms were to be called upon to assist with the work of the brigade. Arguments arising from individual discussions with the farmers were to be published in the press and names of resistant farmers were to be repeatedly announced using a loudspeaker.

During the following week, the work of the brigade was intensified. Meetings were arranged with the school teachers, and the National Front representatives in each house and street were called upon to involve all inhabitants in arguing for the collectivisation. The local ABV was also called upon to produce a list of all inhabitants who worked for state-run institutions or were connected to a collective farm, who might be recruited as agitators. Meetings were arranged too with larger groups of farmers, while other farms were, ominously, marked out to be subjected to 'constant discussion'. On the weekends two members 
of the brigade were charged with organising further agitation groups made up of local inhabitants to ensure there was no let-up of pressure. On top of this, over the course of the week, farmers were invited individually to the town hall for private discussions. After continuous efforts, the agitation brigade's loudspeaker claimed by 24 March that the formation of an LPG had been secured. This included the five farms targeted in the first week, joined by seven more. Nonetheless 30 per cent of the land attached to Kindelbrück remained outside the collective..$^{50}$

The extent to which force was used explicitly in the agitation campaigns is not clear. There is evidence of individual cases in Bezirk Erfurt as in the rest of the GDR where farmers appear to have been driven to suicide in the highly pressured atmosphere of collectivisation. Police reports from March and April 1960 describing such cases deliberately sought to downplay any connection with the tactics of the agitation campaign. Suicide notes, however, provided clear indication in a number of cases of the level of despair the prospect of collectivisation and the actions of agitation brigades had caused..$^{51}$

Certainly acts of resistance to the collectivisation resulted in arrests and in some cases in periods of imprisonment - albeit on other charges. For the majority, however, the participation of the (people's) police as part of the agitation brigades implied threat enough of imprisonment. The 'discovery' of insignificant illegal actions by farmers certainly appears to have been used to break their resistance to entering the LPG. ${ }^{52}$ A letter from the chief of the Kreis Weimar-Land police department to his superiors at the Bezirk describes the situation as follows:

Through intensive investigations carried out by colleagues in the Criminal Department of the Weimar police station it was possible to uncover a number of law-breakers and using individual, tactically correct discussions persuade these same people to join the LPG, without having used force. Thus in serious cases as many as 15 people were invited to the Criminal Department with whom individual discussions were held. As a result of these conversations a whole number of other agricultural enterprises [i.e. farms] have joined in the socialist transformation. Typical for the situation was the fact that it was mostly the spokesmen of the communities who were involved ... However contrary to rumours circulating at the Bezirk attorney's offices, I would like to declare that during these actions no arrests of farmers were made..$^{53}$

It was enough - it seems - for the police to make a show of strength, without actually arresting people. A set of instructions issued by the SED Bezirksleitung to the Kreisleitungen on 21 March illustrates this strategy of persuasion in action again. The document complains that a number of district and village functionaries were not being strict in up- 
holding the law and were therefore themselves hindering the process of socialist transformation in the countryside. As a solution it recommended that the Kreisleitungen follow the example of the SED Kreisleitung in Kreis Arnstadt and form groups of financial experts to assess individual farmers - with the implicit suggestion that any irregularities uncovered could be used to encourage participation in the LPGs. ${ }^{54}$

The use of mayors' offices in which to hold interviews with resistant farmers increased the impression - where it had not been explicitly expressed - of possible state sanctions. The use of the formula which connected support for the collectivisation with support for socialism and hence for peace provided a logical net with which farmers could be threatened and labelled as warmongers should they continue to object. Farmers identified as ringleaders of opposition to collectivisation were especially vulnerable if their war record or some other element of their past could designate them fascist or reactionary. Furthermore there were limits to the farmers' abilities to defend themselves, with forcible prevention of 'trespassing' on their land or indeed mere insults directed at the agitators likely to mark them out as especially hostile.

Alongside open demonstrations of state power, the Ministry for State Security, too, had a covert role to play in driving forward the collectivisation campaign. Assessments by the Ministry's Bezirk administration in January and February 1960 highlight that the Stasi had insufficient numbers of informants working in agriculture, and were thus failing to gain sufficient coverage of the situation in villages across the Bezirk. Nevertheless, where possible, the district offices of the Stasi were encouraged in particular to influence the formation of new LPGs. Those well-off independent farmers who had been recruited (for whatever reason) as Stasi informants, it was suggested, ought to be forced to demonstrate their unambiguous support for collectivisation by joining a collective farm 'voluntarily'. .55

Despite the use or threat of considerable force in the process of collectivisation, it is also clear that some farmers bargained with local and district functionaries for their participation in the LPG. The urgency of the agitation brigades' requirement for a signature or an agreement in order to be able to claim that full collectivisation had been achieved within their area on time, certainly led to verbal concessions to the farmers' desires. The wish of some larger farmers to form their own collective, to the exclusion of weaker, small farms, while not permitted in the initial months of the collectivisation campaign, was allowed as the deadlines grew imminent. Thus a police report on Kreis Nordhausen in April mentions villagers' irritation that three of the largest and best farmers had been allowed to set up an LPG Type I on their own. ${ }^{56}$ Certainly 
there were limits to how far such bargaining could go. A fifteen-point set of written conditions for entry into the LPG, which one farmer dared to put to the mayor in March 1960 in a village in Kreis Sömmerda, led to the involvement of the Stasi. ${ }^{57}$ Nevertheless, if the claims of some farmers following collectivisation are to be believed, far-reaching concessions were indeed granted in return for their acceptance of the LPG. These ranged from the freedom to harvest independently in 1960 to guarantees of a certain level of profit or wage, which matched their previous incomes. Thus a police report from 23 March 1960 points to increasing demands from farmers in Kreis Sömmerda in return for LPG entry, such as a minimum wage of 400DM or full reimbursement for the livestock and equipment brought into the collective. Requests were also made for documents allowing travel to West Germany in return for joining an LPG. ${ }^{58}$

According to statistics produced by the SED Bezirksleitung after collectivisation had been nominally completed on 2 April, between 21 March and 1 April the percentage of arable land in the Bezirk farmed collectively doubled from 40 to 80 per cent, entailing quite literally the founding of farming collectives overnight, particularly on the weekend of 25 March to 27 March. ${ }^{59}$ The situation on paper was a long way removed from the reality, however. Sufficient signatures might have been gained agreeing to participation in the LPG, but the terms on which these agreements were reached did little to assuage the doubts of both farmers and many functionaries as to the long-term viability of LPGs. Nor indeed, despite the publication of model statutes in 1959 detailing the organisation of collective farms, was there certainty as to how the practice of collective farming should be undertaken.

\section{Conclusion}

Once the success of reaching full collectivisation throughout the Bezirk had been celebrated with greater or lesser degrees of sincerity in the villages in April 1960, the difficult task of establishing actual functioning collective farms began. The practical purpose behind forming the collectives was to achieve large field cultivation of crops and larger, more concentrated livestock holdings which allowed production to be increased as well as more effectively planned and controlled. Conditions thus had to be created in which these goals could be realised, while in addition basic questions of how the collective farm was to be managed and who was to do it had to be addressed. Other fundamentals of organisation such as the calculation of wages, the division of 
profits, the allocation of private plots, working hours and delegation of responsibility had also to be settled in practice among the members. Alongside these organisational issues, however, farmers had still to be convinced to be as good as their signature and actually work together in the collective.

The collectivisation was an impressive feat of administration, but neither the political nor the practical argument had been won for most farmers. In addition, the collectivisation process itself had demonstrated the limitations of the SED regime's authority in rural areas. Worse still, the manner in which the collectivisation had taken place had left plenty of room for future conflict and recrimination in rural communities in general, and disorganisation and uncertainty over the future practice of farming and administration of agriculture. There was, too, a real danger that this attack on farmers would rebound on the population at large through food shortages. New parameters had been set in which the transmission of authority in agriculture and rural society were to function. Farmers and the SED regime (and its local representatives) had signed up to a new set of roles and responsibilities with completion of full collectivisation - how these roles and responsibilities were to be interpreted and transformed into practice was by no means settled, however.

In the following chapter the bases of conflict and the expression of opposition in the aftermath of full collectivisation will be examined, along with the processes through which regional and local functionaries sought to resolve these conflicts and consolidate political, financial and organisational stability within LPGs prior to the increased restriction of flight to the West resulting from the construction of the Berlin Wall on 13 August 1961.

\section{Notes}

1. Thüringisches Hauptstaatsarchiv Weimar (ThHStAW) Bezirksbehörde der Deutschen Volkspolizei Erfurt (BDVP) 20/134 Volkspolizeikreisamt Mühlhausen, Abt. Schutzpolizei, Ergebnisse der Auswertung der Brigaden innerhalb des MTS-Bereiches Görmar, 10.12.1959.

2. The early development of the LPG in Merxleben as described by Barbara Schier highlights the mixture of local impetus and state interference in the establishment of the very first collective farms. B. Schier, Alltagsleben im 'Sozialistischen Dorf', Münster, 2001, pp. 112-21.

3. C. Nehrig, 'Landwirtschaftspolitik', in Die SED. Geschichte - Organisation Politik. Ein Handbuch, eds A. Herbst, G.-R. Stephan and J. Winkler, Berlin, 1997, pp. 294-305, here p. 295. 
4. F. Werkentin, Politische Strafjustiz in der Ara Ulbricht, Berlin, 1995, pp. 73-85.

5. P. Kermarrec, Der 17. Juni 1953 im Bezirk Erfurt, Erfurt, 2003, pp. 67-71.

6. ThHStAW BDVP 20/134 BDVP Kriminalpolizei, Bericht an die Hauptverwaltung der Deutschen Polizei, Fälle über Proklamierung eines neuen 17. Juni. 26.3.1955.

7. The trials and tribulations of the LPG in Merxleben described in detail by Barbara Schier are instructive in this regard, bearing in mind that as the first LPG to be set up in the Bezirk, the regime had a vested interest in ensuring its success. Schier, Alltagsleben, pp. 121-44.

8. ThHStAW BDVP 20/044 Bericht an die BDVP - Politabteilung, Wahleinsatz im VPKA Apolda und Mähdrescherwerk Weimar, 13.6.1957.

9. ThHStAW Rat des Bezirkes (RdB) Erfurt L1151 Rat des Bezirkes Erfurt, Abt. Landwirtschaft, Bericht über den Stand der sozialistischen Entwicklung der Landwirtschaft im Bezirk Erfurt im 1. Halbjahr 1958.

10. Beauftragte für die Unterlagen des Staatssicherheitsdienstes (BStU) Aussenstelle Erfurt, Bezirksverwaltung Erfurt, Büro der Leitung 1481 Leitung der MfS Bezirksverwaltung an den Leiter der Kreisdienststellen, Orientierung auf die Schwerpunkte der operativen Arbeit der Linie III (Landwirtschaft) im I. Quartal 1959, 18.12.1958, p. 8.

11. J. Gruhle, Ohne Gott und Sonnenschein, Nauendorf, 2000, p. 58.

12. ThHStAW RdB Erfurt L1151 Rat des Bezirkes Erfurt, Abt. Landwirtschaft, Bericht über die Entwicklung der LPG seit der 15. Tagung der Bezirksleitung der SED und des Bezirkstages am 23.8.1957.

13. C. Klessmann, 'Zur Sozialgeschichte des protestantischen Milieus in der DDR', Geschichte und Gesellschaft 19, 1993, pp. 29-53.

14. For Bezirk Erfurt, these battles are thoroughly analysed in M. Allinson, Politics and Popular Opinion in East Germany, 1945-1968, Manchester, 2000, pp. 87-108.

15. ThHStAW BDVP 20/044 BDVP Politabteilung, Bericht an die Hauptverwaltung - Politische Verwaltung, 10.12.1957.

16. T. Bauer, Blockpartei und Agrarrevolution von Oben. Die DBD 1948-1963, Munich, 2003, p. 441.

17. District officers of the Stasi were given instructions to prevent such farmers from taking up positions on the boards of the LPG or being chosen to occupy leading functionary positions. In practice of course this proved rather harder to ensure, as one case in the village of Ramsla demonstrated. Here an LPG Type I was established by a farmer who owned 30 hectares of land along with two other farmers. The LPG ran initially as something of a family business with the Großbauer himself chairman, his son the field brigadier and his daughter the accountant. Despite this seemingly inauspicious ideological composition, this LPG, as it transpired, became something of a model of socialist development. BStU Aussenstelle Erfurt, Bezirksverwaltung Erfurt, Büro der Leitung 1481, Leitung der MfS Bezirksverwaltung an den Leiter der Kreisdienststellen, Orientierung auf die Schwerpunkte der operativen Arbeit der Linie III (Landwirtschaft) im I. Quartal 1959, 18.12.1958, p. 8; BStU Aussenstelle Erfurt, Kreisdienststelle Weimar 682, Analyse über das Dorf Ramsla, 2.6.1960, pp. 33-40.

18. Allinson, Politics and Popular Opinion, p. 78. 
19. Gruhle, Ohne Gott, p. 85: "'Zwar sehe ich ein, dass man die besseren Entwicklungsmöglichkeiten hat, aber ich will meine Freiheit haben."'

20. LPGs were divided into three types: Type I required the collective use of only the land; Type II required the use collectively of both land and machinery; Type III required the collective use of land, machinery and livestock. ThHStAW RdB Erfurt L562, Rat des Bezirkes Erfurt, Abt. Landwirtschaft, Bericht über die politische und ökonomische Entwicklung der LPG 1959 und den Stand der Betriebsplanung 1960.

21. ThHStAW BDVP 20/134 Kriminalpolizei, VPKA Mühlhausen, Abt. Schutzpolizei - Instrukteurbereich II. Auswertung der Brigadeeinsätze innerhalb des MTS Bereiches Lengefeld zur soz. Umgestaltung der Landwirtschaft, 4.12.1959.

22. BStU Aussenstelle Erfurt, Kreisdienststelle Heiligenstadt TA 184/84 Mündlicher Bericht des GI 'Traktor' beim Treff am 14.11.1958, 18.11.1958, pp. 70-71.

23. BStU Aussenstelle Erfurt, Kreisdienststelle Heiligenstadt TA 184/84, Eigener Treffbericht, Treff mit GI 'Traktor', 5.12.1958, 9.12.1958, p. 72.

24. ThHStAW RdB Erfurt L562 Rat des Bezirkes Erfurt, Abt. Landwirtschaft, Bericht über die politische und ökonomische Entwicklung der LPG 1959 und den Stand der Betriebsplanung 1960; Gruhle, Ohne Gott, pp. 76, 87.

25. As Jonathan Osmond has pointed out, some wealthier farmers sought, however, to avoid joining an already existing LPG and to limit outside interference by forming their own LPG Type I: J. Osmond, 'From Junker Estate to Cooperative Farm: East German Agrarian Society 1945-1961', in The Workers' and Peasants' State: Communism and Society in East Germany under Ulbricht, 1945-1971, eds P. Major and J. Osmond, Manchester, 2002, pp. 130-50, here p. 139.

26. ThHStAW Bezirksparteiarchiv der SED Erfurt, Bezirksleitung der SED Erfurt BIV/2/4-103 KPKK Sömmerda, Bericht über die Untersuchung in der LPG Kindelbrück, 18.6.1958, pp. 98-100.

27. ThHStAW Bezirksparteiarchiv der SED Erfurt, Bezirksleitung der SED Erfurt BIV/2/4-103 KPKK Sömmerda an die BPKK, Bericht der KPKK über die Untersuchungen in Grossmonra, 9.6.1959, p. 113.

28. See Gruhle, Ohne Gott, p. 45 for an example in Barchfeld, Kreis Weimar an MTS Brigadier was replaced for neglecting the LPG and serving the Großbauern.

29. ThHStAW RdB Erfurt L562 Rat des Bezirkes Erfurt, Abt. Landwirtschaft, Bericht über die politische und ökonomische Entwicklung der LPG 1959 und den Stand der Betriebsplanung 1960. Following, for example, the transfer of machinery to the LPG Tüngeda in Bad Langensalza, six independent farmers applied for entry.

30. Bauer, Blockpartei, p. 442.

31. BStU Aussenstelle Erfurt, Bezirksverwaltung Erfurt, Büro der Leitung 1446, Leitung der Bezirksverwaltung an die Leiter der Kreisdienststellen, Orientierung auf die Schwerpunkte der Linie III in Auswertung der Arbeitstagungen vom 11.1.1960 und 16.2.1960, 19.2.1960.

32. ThHStAW Bezirksparteiarchiv der SED Erfurt, Bezirksleitung der SED Erfurt IV/2/2-322 SED Bezirksleitung Abt. Landwirtschaft an das Sekretariat: 
Bericht über die Vorbereitung der Organisationswahlen der VdgB und ihre Unterstützung durch die Partei, 12.3.1960, pp. 168-76.

33. ThHStAW BDVP 20/065 BDVP Stab/Operativstab, Information 16/60 Vorkommnisse in der Landwirtschaft, 22.3.1960.

34. ThHStAW BDVP 20/134 BDVP Kriminalpolizei, Kontrolle und Anleitung bei der Abt. K. Mühlhausen am 26.11.1959.

35. ThHStAW BDVP 20/106 BDVP Schutzpolizei, Bericht über die Kontrolle und Anleitung im VPKA Heiligenstadt 19.10-14.11.1959; 20.11.1959. Also Allinson, Politics and Popular Opinion, pp. 79-80.

36. ThHStAW BDVP 20/065, Stab/Operativstab, Information 6/60, 24.2.1960.

37. ThHStAW, RdB Erfurt L562 Rat des Bezirkes Erfurt, Abt. Landwirtschaft Bericht über die politische und ökonomische Entwicklung der LPG 1959 und den Stand der Betriebsplanung 1960, undated (Feb. 1960).

38. Gerhard Grüneberg (1921-81) was Secretary for Agriculture in the ZK between 1960 and 1980, and from 1966 was a member of the Politburo of the ZK.

39. Bauer, Blockpartei, p. 461.

40. Gruhle, Ohne Gott, p. 168: 'Die Zusage der Unterbringung war vorhanden, und als die Genossen hinkamen, waren die Türen verschlossen ...'

41. ThHStAW BDVP 20/065 BDVP Stab/Operativstab, Information 6/60 Landwirtschaft, 24.2.1960.

42. ThHStAW RdB Erfurt L590 Rat des Bezirkes Erfurt, Abt. Landwirtschaft, Einschätzung über die Stadt Kindelbrück, 3.3.1960.

43. See Osmond, 'From Junker Estate to Cooperative Farm', p. 140.

44. ThHStAW NF 136, Bezirkssekretariat, Erster Entwurf, Dorfplan 1960 der Gemeinde Wandersleben, Kr. Gotha p.1; Bezirkssekretariat, Beschluss Brigadeeinsatz Wandersleben, 29.12.1959, p. 14; Bezirkssekretariat, Kurzanalyse über die Situation in Wandersleben, Kreis Gotha, 9.1.1960, p. 21.

45. ThHStAW BDVP 20/065 BDVP Politabteilung Information 5/60 Landwirtscaft, 15.2.1960.

46. ThHStAW BDVP 20/134 BDVP Kriminalpolizei, Abt. K. Dezernat SE: Bericht über die Mitarbeit der Volkspolizei bei dem Brigadeeinsatz zur soz. Umgestaltung der Landwirtschaft, 27.11.1959; ThHStAW RdB Erfurt L590 Rat des Bezirkes Erfurt, Abt. Landwirtschaft, Einschätzung über die Stadt Kindelbrück, 3.3.1960; ThHStAW BDVP 20/065 BDVP Stab/Operativstab Information 17/60: Information und Gerüchte, 23.3.1960; ThHStAW BDVP 20/134 Kriminalpolizei, VPKA Mühlhausen, Abt. Schutzpolizei, Ergebnisse der Auswertung der Brigaden innerhalb des MTS-Bereiches Görmar, 10.12.1959.

47. ThHStAW BDVP 20/134 Kriminalpolizei, VPKA Mühlhausen, Abt. Schutzpolizei - Instrukteurbereich II. Auswertung der Brigadeeinsätze innerhalb des MTS Bereiches Lengefeld zur soz. Umgestaltung der Landwirtschaft, 4.12.1959.

48. ThHStAW BDVP 20/065 BDVP Stab/Operativstab Information 17/60: Argumente und Gerüchte, 23.3.1960.

49. Allinson, Politics and Popular Opinion, p. 82.

50. ThHStAW RdB Erfurt L590 Rat des Bezirkes Erfurt, Abt. Landwirtschaft, Einschätzung über die Stadt Kindelbrück, März 1960. 
51. BArch DP 1, Nr. 1150 Ministerium der Justiz, HA II, Tägliche Rapporte des Operativstabs der DVP über die Lage in Berlin und in den Bezirken der DDR: 'On 2.4.1960 in ... Bezirk Karl-Marx-Stadt a farmer committed suicide by hanging. His family claim that over the last four weeks agitators have been campaigning almost daily for his entry into the LPG and that therein lie the grounds for the suicide. On 11.4.1960 at around 4 am a private farmer in ... Bezirk Karl-Marx-Stadt committed suicide by hanging. In his suicide note, he stated that he did not want to join the LPG.'

52. Thus a list of 'illegal activities' was collected by the brigade operating in Kindelbrück as part of their campaign. ThHStAW RdB Erfurt L590 Einschätzung über die Stadt Kindelbrück - Feststellungen der Brigade zu Fragen der Ungesetzlichkeiten.

53. ThHStAW BDVP 20/081 Stab/Operativstab, VPKA Weimar an die BDVP Stellvertreter Operativ, Bericht über den Instrukteureinsatz zur Unterstützung der Amtsleitung des VPKA Weimar bei der sozialistischen Umgestaltung der Landwirtschaft, 28.3.1960.

54. ThHStAW Bezirksparteiarchiv der SED Erfurt, Bezirksleitung der SED Erfurt IV/2/2-322 SED Bezirksleitung Fernschreiben an alle 1. Kreissekretäre Beschluss-Protokoll Nr. 10/60 der Sekretariatssitzung vom 21.3.1960, p. 144.

55. BStU Aussenstelle Erfurt, Bezirksverwaltung Erfurt, Büro der Leitung 1446, Leitung der Bezirksverwaltung an die Leiter der Kreisdienststellen, Orientierung auf die Schwerpunkte der Linie III in Auswertung der Arbeitstagungen vom 11.1.1960 und 16.2.1960, 19.2.1960.

56. ThHStAW BDVP20/065BDVPStab/Operativstab Information 10/6026.2.1960; Information 18/60 21.4.1960.

57. ThHStAW BDVP 20/065 BDVP Stab/Operativstab Information 14/60, Landwirtschaft 21.3.1960.

58. ThHStAW BDVP 20/065 BDVP Stab/Operativstab Information 17/60 Argumente und Gerüchte, 23.3.1960.

59. Gruhle, Ohne Gott, p. 208: 'Die zweite Übersicht zeigt dass die Forcierung der Agitationseinsätze bewusst auf das Wochenende vom 26. und 27. März 1960 her zugeschnitten worden war.' 


\section{of 2}

\section{The Aftermath of Collectivisation}

The laws and regulations are not applicable to us. We as farmers have the say over our agriculture. ${ }^{1}$

(Farmer, Mosbach, Kreis Eisenach reported by the police in September 1960.)

The massive deployment of agitation brigades in the countryside and a number of tactics ranging from genuine persuasion through to public humiliation, intimidation and incarceration succeeded in moving the vast majority of farmers in the GDR to sign up to a collective farm. Beyond the paperwork, however, the situation was by no means so clearcut. It was one thing for farmers to be brought to sign up to participation in a collective farm, it was quite another for these farms to get up and running in practice. The farmer quoted above was by no means alone in his sentiments and the apparatus of communication and control available to the SED leadership in the countryside proved itself inadequate to take concerted action against farmers who insisted upon their independence.

The model statutes according to which LPGs were supposed to be organised - established first in 1952 and modified in 1959 - were not entirely unfamiliar to most of the newly collectivised farmers. Most had some knowledge of a nearby LPG and discussion of the content of the three types of model statute had been part of the agitation campaign. Nonetheless, the assumption of the roles and responsibilities laid out in the model statutes was no simple matter and represented considerable changes not only to farmers' daily routines, but also to their relationship with their fellows, their land and, in the LPG Type III, to their livestock. It changed above all their sense of their own status. Relinquishing individual control over property was considered tantamount to expropriation, and participation in a collective brigade under another's authority was tantamount to becoming a farm labourer. ${ }^{2}$ Rural communities were thus fraught with discord and many farmers continued to reject the agricultural collectives, refusing to take part in collective work and in some cases abandoning their farms and fleeing the GDR altogether. The speed and aggression with which the collectivisation campaign had been completed, and the inadequacies of the 
regime's apparatus for governing agriculture and rural society at a local level limited further the prospects for swift acceptance of collective farming practices. Nevertheless, amid all the conflict, disruption and uncertainty at this time, both older and new LPGs did begin a slow, by no means immediately successful, process of consolidation. New parameters were officially set to the relationship between the individual farmer, his community and the state, and the longer the LPGs survived the more necessary it became to assert one's interests within rather than against them.

\section{The Conditions of Collectivised Agriculture}

These new parameters - the conditions in which farming was now to take place - were defined in part by the 1959 LPG Law and the three different types of model statute which provided the basis for the rights and responsibilities of collective farmers and dictated the basic administrative and financial structure of collective farms. ${ }^{3}$

The LPG Type I was aimed clearly at those who wished to retain as much independent control over their property as possible. The only aspect of farming which had to be managed collectively was the arable land brought in by each farmer. It was therefore an obvious choice for the majority of those who formed an LPG, reluctantly, during 'the Socialist Spring'. Of central importance to Type I farmers was their continued private use and ownership of their own livestock and the stipulation that at least 40 per cent of the profits of the LPG had to be shared among the members according to the amount of land each one had contributed to the collective farm. With these embellishments, the bitter pill of collectivisation and the sense of expropriation and loss of independence were at least to some extent mitigated. Nonetheless, the model statute's aim was to commit the farmers who had agreed to it (albeit in most cases under some sort of duress) to developing real forms of collective practice, at least as far as the arable land was concerned: clause II.4 unambiguously required the removal of any border markers and divisions between field plots, the amalgamation of fields and the use of a crop rotation in accordance with state plans.

Although the members continued to own privately their own machinery, they were required to put these at the disposal of the LPG in return for a suitable rent should the majority of the members' assembly vote for it. The concessions to the will of farmers to retain their independence were not insignificant; however, the formation of the LPG as an institution was nonetheless a radical and symbolic step. The establish- 
ment of an administrative structure - comprising ideally a hierarchy of a chairman and managing board, brigades and brigade leaders, as well as an accountant and various commissions - provided the means for the SED state to gain more consistent and more comprehensive control over farmers and all aspects of agricultural production. Moreover, the LPG Type I, as the first of three types, was recognisably a stepping stone on the way to much greater degrees of collectivisation of property: those who formed the LPG Type I realised it was unlikely that their children would be able to inherit as much individual control over land, livestock and machinery.

The model statute of the LPG Type II entailed an immediate commitment to progressively reducing private ownership of livestock in the interests of developing collective herds. Here the arable land, machinery, equipment and draft animals - as far as they were not necessary for farming independently kept land and livestock - were held by the collective and only 30 per cent of profits were shared according to the amount of land contributed. Only very few new farmers chose to form an LPG Type II, seeing little benefit in adopting a statute which was explicitly geared towards transition to greater collective control sooner rather than later.

The Type II statute's significance lies largely in its use as a legal tool for shifting the terms on which farmers 'agreed' to participate in the LPG. As of 1962, the right of farmers to withdraw from the collective was redefined in an altered Type II statute as being valid only if so doing was 'for the benefit of society'. This was a suitably vague term giving the state apparatus the explicit sanction of the law in its long-running battle to prevent LPGs - of all types - haemorrhaging much-needed manpower and expertise. In being prevented from withdrawing from the LPG or taking up other careers unless they had the full agreement of the Rat des Kreises, the individual LPG management and a majority of their fellow LPG members, farmers had increasingly to face up to the prospect of earning their livelihood only under the conditions of collective farming. The incentive for making the best of an inescapable situation (given that fleeing the country for most was not a realistic option even before the Berlin Wall had been constructed) became increasingly apparent. For some formerly independent farmers, confident in the permanence of the SED regime, the lack of alternatives to collective farming encouraged them to embrace it fully by taking up the statute of the LPG Type III, rather than cling on to what vestiges of the old system were available to them.

In contrast to the LPG Type I, the model statute of the LPG Type III entailed comprehensive acceptance of the collective farming idea - it 
committed farmers to building up collective livestock, placed grazing land in collective use alongside the arable land and presupposed the most active participation in the life of the collective farm, placing minimal emphasis on property and maximum on labour. In all types of LPGs, members had the right to retain private use of a certain amount of arable land as well as a garden plot. The amount of individual land according to the model statute was not to exceed half a hectare for each household in the LPG - the idea being in theory to prevent a family with several LPG members accumulating a private plot of several hectares.

While farmers in other types of LPGs were able to retain their own livestock, farmers in Type III were restricted to a small, set number of animals that might be kept for private use, thereby limiting the distinction in incomes between members and ensuring everyone continued to devote themselves to work for the collective. ${ }^{4}$ Eighty per cent of the profits of the Type III LPGs were to be shared among the members according to the amount of labour they contributed. ${ }^{5}$ Only 20 per cent was shared on the basis of land contributions. As such the LPG Type III was the preferred choice of all those who had little more than their labour to contribute to the farm. With such a balance, it was necessary for all members to devote most of their time to work for the collective in order to earn sufficient income.

On entry into an LPG Type III, a minimum contribution had to be made to the basic material and financial capital of the collective farm. This was paid either in cash, often in instalments, or in the form of livestock, equipment and buildings required by the collective. Most of the Type III LPGs in Bezirk Erfurt were founded before the 'Socialist Spring', taking over abandoned land and relying on the manpower of workers recruited from industry, landless farm labourers and smallholders. While having the most state backing, they rarely were in possession of the best land and livestock or the most expert workforce. The completion of collectivisation changed this to some extent by compelling some independent farmers to join existing Type IIIs, transferring in the process their land, livestock and machinery to collective control. In theory, contributions to the wealth of the LPG in excess of the minimum (set generally at 500 Marks) were to be eventually repaid: the inconsistency with which this was done, however, became a lasting source of anger among LPG members, who continued to call for payment of money owed them by the state since 1960 right up to $1990 .{ }^{6}$

Although there was some choice in the type of LPG farmers joined as long as they joined one - it was certainly constrained in some cases by practical considerations (i.e., ensuring an LPG's financial stability or the adjacency of members' lands) as well as the degree to which col- 
lectivisation was pursued as a means of social engineering. Most often more than one LPG existed in a single community but the constellation of farms in each one did not necessarily reflect a harmonious balance between the interests of each of the members.

\section{The Roots of Conflict in the LPG}

The administrative collectivisation of agriculture represented a considerable step in the social reconfiguration of rural society in the GDR. It rarely gave rise, however, to newly harmonious social relations within the village. Rather, old conflicts were given new form and new vigour. Between 1945 and 1960 the social structure of villages in Bezirk Erfurt had been shaped by the influx of refugees from the East and the expansion of industry as well as the gradual erosion of the local authority of the traditional village elites. The collectivisation process during the 1950s, the exodus of people to the West, the development of the MTS and the influx of industrial workers to work in the LPGs as part of a statesponsored programme, as well as consistent efforts to limit the influence of the local pastors over the rural population, among other things, complicated the network of social relations and loyalties in many villages. Beneath the blanket of administrative full collectivisation in 1960 a tangled set of antagonisms continued thus to exist within and between the various LPGs based on politics, religion, class and the rights of new and old settlers. ${ }^{7}$

While one has to be wary of simply accepting the designations of socialist rhetoric as corresponding to the real roots of conflict within rural communities, it is reasonable to accept that in some LPGs those who saw themselves as victims or opponents and those who were beneficiaries and supporters of socialist agricultural policy were perforce brought together within the collective farms. The wealthiest farmers and traditionally dominant figures of rural communities (so-called Großbauern) had now to work together with those whom they had once considered their social inferiors and accept not only the common use of their property but also their newly non-elite status. Although compelled to be part of the LPGs, some wealthier farmers sought where possible to continue to assert themselves, threatening non-cooperation when attempts were made to reduce their share of the LPG's income on the basis of the land they had contributed. ${ }^{8}$

Attempts to implement the statutory right of the members' assembly to set limits on the proportion of land and number of animals which were deemed to belong to any individual member also provoked con- 
siderable resistance. By October 1960 the restriction of wealthier farmers' property had not been completed in any of the districts in Bezirk Erfurt. In Kreis Weimar only eight out of a possible eighty individual farmers and in Kreis Heiligenstadt not a single farmer had had his property curtailed. Großbauern in the LPG Pfiffelbach, Kreis Apolda, sought for example to undermine attempts to reduce the number of livestock they owned privately by agreeing that the LPG could take their animals but refusing absolutely to agree to contract the use of their livestock sheds to the LPG even though these buildings would then stand empty. ${ }^{9}$ In the long run Großbauern did have to accept that their buildings and animals were for the most part at the disposal of the collective; actually carrying out this transferral of control, however, provoked confrontation which few LPG leaders relished.

In a few cases, faced with what they saw as blatant invasion of private property and daylight robbery, individual farmers put up some last-ditch resistance: a farmer in the LPG Type III Hardisleben, faced with the prospect of the LPG converting his sheep pen into cattle stalls, was reported to have tried to prevent it, saying: 'You aren't coming into my stables. That's my property, you just want to expropriate it. Anyway this LPG isn't going to last much longer. ${ }^{\prime 10}$ Even in late 1961, a farmer in the village of Daasdorf was so angered by the transference of his animals from his sheds to collective livestock holdings that he was reportedly moved to threaten the livestock brigadier, saying, 'Just you wait, when things are different, it'll be your turn. ${ }^{11}$

Even where the questions of lost property and status were not writ large, social divides between successful private farmers and the Neubauern, small farmers and agricultural labourers who had founded the LPG, could be enough cause for conflict. ${ }^{12}$ Antagonism came not simply from those who were unwilling to collectivise. Indeed even assessments by SED functionaries appear as quick to highlight and condemn instances of sectarianism by long-standing LPG members and small farmers almost as often as they condemn the machinations of the 'class enemy'. Long-standing LPG members were not necessarily willing to share what they had achieved with those who until recently had looked down on their efforts and who (initially at least) certainly did not share their politics or their interests in the success of the LPG. Furthermore, smaller farmers who until March 1960 had nonetheless managed to run a successful farm had no desire now to be under the command of either their richer neighbours in the LPG Type I or what they regarded as inferior farmers in the LPG Type III. ${ }^{13}$

A major source of conflict between members in the LPGs was the balance between the manpower supplied by each household and the 
amount of land brought in. As long as one member of the household joined the LPG along with the farm, the whole household had the benefit of the half hectare of individual land while other relations were free to tend privately kept livestock or pursue careers outside farming. In the first year after the 'Socialist Spring' it was a regular source of antagonism in some LPGs that the wives and children of farmers who had contributed a large amount of land could nevertheless not be made to take part in helping to cultivate it. Small farmers thus found themselves farming the lands of their wealthier neighbours (who still received a share of the profits according to the land they had contributed) and yet unable to achieve nearly as good an income. In the LPG Type II in Nöda, Kreis Erfurt, complaints were made by former Kleinbauern (small-scale farmers) against two Großbauern whose wives and children had avoided joining the LPG. The daughters of one of these farmers had found lucrative office jobs instead of farm work and thus appeared, it was argued, to be enriching themselves on the backs of their poorer neighbours. ${ }^{14}$

In particular, that some farmers' wives were able to hold themselves aloof from the women who went to work in the LPG seemed to highlight the failure of collectivisation to change the social inequalities of the village. With regard to the LPG Rudisleben it was reported, for example, that the LPG members were minded not to let their wives work in the fields, as the wives of the former Großbauer did no such thing either. Their complaint was given greater force by their wives' objections to the dictatorial manner of the deputising field brigadier who happened also to be the son of one of the ex-Großbauer. ${ }^{15}$

Given these tensions, those members of the LPG who were chosen for, or persuaded to take up, leading functions often soon found themselves unable to organise the collective farm efficiently. In the months after the completion of the collectivisation campaign several newly appointed chairmen and brigadiers chose to resign, claiming a lack of confidence in their own abilities to carry out the tasks required of them. ${ }^{16}$ Certainly, running an LPG was a considerable burden with very little material reward being offered in return. The work was not made more attractive by the potential for antagonism and social exclusion at the hands of one's colleagues and neighbours, nor by having to face the wrath of the district agricultural functionaries, especially if the LPGs were failing economically or the members were openly failing to adhere to the statute. LPG functionaries understandably found their unaccustomed leadership duties, caught between their responsibilities and obligations to those above and beneath them in the new hierarchy, difficult to bear. For example, a field brigadier resigned from his post in the LPG Type III Windeberg Kreis Mühlhausen reportedly on the grounds 
that he regularly had difficulties assigning work to the members who often did not obey his instructions. ${ }^{17}$ In May 1960 the aggrieved chairman of an LPG in Kreis Nordhausen sent a letter of resignation to the local mayor on the basis that he could not continue unless he had the confidence of the members. ${ }^{18}$ Particularly after the harvest in autumn 1960, the boards of newly formed LPGs in Worbis, Heiligenstadt and Mühlhausen districts lapsed entirely. The main reason given for board members to resign from their positions as functionaries was the desire to 'live peacefully' like the other members. ${ }^{19}$

Ideally, the SED leadership hoped to be able to consolidate the LPGs rapidly, implement the model statutes and achieve the leap forward in agricultural production which had been a strong motivation for the hasty completion of the collectivisation campaign. The actual state of affairs in most new LPGs and many older ones in April 1960 made the realisation of these goals highly unlikely. In the long term, the collectivisation campaign and its aftermath were useful to the SED regime in the extent to which it identified those individuals on whom it could rely and exposed those aspects of its administration of agriculture and rural communities that were ineffective, inefficient or unreliable. The zeal with which some agitators had advanced the cause of collectivisation was a sign that the regime could call upon some loyal and obedient proponents of socialist transformation. Particularly those who lived or worked in rural communities and thus had campaigned and supported the formation of LPGs at the risk of lasting opprobrium from their neighbours and colleagues had demonstrated the existence of a base for support for socialist agricultural policy on which more secure foundations might be built. Those anxious to see that collectivisation worked well were, however, few in number compared to the majority of LPG members, who regarded a future in the collective farm without enthusiasm, if not with varying degrees of resistance and in some cases open opposition.

The means at the SED's disposal for overcoming such negative responses to the LPG (provoked in part by the speed and aggressiveness with which the campaign had been conducted) were greatly limited. Implementing collective practices and suppressing dissent had to be carried out if the collectivisation were to have any positive benefit in the long term. For the time being, however, the apparatus available on the ground for achieving these goals was manifestly insufficient given the size of the task. Moreover, the subversion of collective practices or resistance to their implementation in the first place remained particularly strong in the light of widespread uncertainty over the future of collective farming and indeed the GDR itself. 


\section{The Insufficiency of the SED State's Apparatus in Rural Communities}

In the previous chapter detailing the course of the collectivisation process in Bezirk Erfurt, it became clear that the local apparatus of the regime was able to achieve only a limited degree of success in persuading farmers to join or form an LPG. In order for the rapid completion of full collectivisation to be achieved (albeit on paper only), a massive effort had been necessary in which large numbers of agitators from outside farming or the immediate community were deployed. LPGs had thus been formed (or expanded) often without the absolute backing of large sections of the local state administration and the politically organised population in the village. The campaign for full collectivisation had, too, been marked in its last months primarily by the prioritisation of speed rather than thoroughness. The aggressive tactics employed during the collectivisation had succeeded in 'persuading' farmers to sign up to an LPG, but local administrations and the LPGs themselves remained largely lacking in suitable (politically loyal and technically expert) staff and resources to ensure the collective farms functioned in practice. Attempts to consolidate the newly formed collective farms and stabilise agriculture in the aftermath of collectivisation were thus compromised both by the widespread dissent among farmers with regard to the LPGs and by an apparatus of local administration and control ill-equipped either to assuage or control this dissent and ineffective at establishing and sustaining collective farming in accordance with the statutes.

As early as April 1960 a brigade of investigators was organised by the SED Bezirksleitung to assess the effectiveness of the local party and state apparatus in Kreis Apolda. Its main task was to 'put the work of the party and leadership by the SED Kreisleitung and by the state apparatus in order and mobilise all forces in the inclusion of large sections of the population in the socialist development of the district'. It found much to criticise. The SED Kreisleitung, in lacking an overview of the situation in the district, had not only failed to practise its leading role with regard to the state apparatus and the mass organisations but had also been negligent in giving suitable guidance to the SED party organisations in the villages and LPGs. As far as the state apparatus was concerned the brigade also found evidence of serious ideological weakness, particularly among those functionaries belonging to the CDU and LDPD (Liberal Democratic Party) who did not always appear to recognise the leading role of the SED. Leading functionaries in the Rat des Kreises were deemed to have an 'unclear' attitude towards collectivisation. Their 'lazy liberalism', it was suggested, had allowed mayors un- 
necessarily to lower the plan targets due from farmers in the Bezirk. Moreover, fifteen out of forty-seven village mayors were considered in need of replacement by cadres better equipped to cope with the sorts of political and technical matters which now faced local functionaries since the completion of collectivisation..$^{20}$ Although this state of affairs was recognised, there were limits to what could be done to rectify the situation. In Kreis Apolda, for example, it was ultimately pointed out that fifteen suitable replacements for mayor simply did not exist. ${ }^{21}$

The lack of personnel was a serious problem throughout the agricultural and rural administration. Immediately following the establishment of a fully collectivised village, the SED Bezirksleitung had directed the operative committees for collectivisation to delegate groups of specialists, agronomic experts as well as experienced farmers from the VEGs and long-established LPGs, in order to ensure that 'the organisation of work is taken properly into hand in collective farms'.$^{22}$ Following the announcement of full collectivisation, a number of local brigades of specialists were thus deployed in some LPGs. These, however, were clearly not sufficient in number to monitor the progress of all the LPGs all of the time. Investigations at the end of June into the cultivation plans for the upcoming harvest revealed not only rejection of the state directives on the planting of certain crops but also widespread breakdown in collective work. As a consequence, calls were made for the immediate redeployment of large numbers of troubleshooting brigades throughout the Bezirk. ${ }^{23}$

A report on the state of the LPGs compiled by the Rat des Bezirks in July 1960 summarised the situation in Bezirk Erfurt just after collectivisation. Out of the 1,390 LPGs then officially registered in the Bezirk, over 40 per cent were Type I LPGs, which had been formed over the last three months. Somewhat optimistically attributing most of the problems within the collectives to a lack of clarity on political questions which it asserted simple explanation could resolve-the report suggested that serious difficulties existed in only seventy Type I LPGs, where the transition to collective farming had not been 'entirely completed' ${ }^{24}$ This was, however, something of an understatement - opposition to collective farming was much deeper and much more widespread and the structures in place to control it much weaker than the report gave credit.

In July the SED Bezirksleitung drew up plans for the organisation of brigades to assess developments in the sixty-eight villages of Kreis Nordhausen. It planned for the deployment of two to three people in each village. The Rat des Kreises was required to provide one person for each of these groups while the rest were to come from various departments of the Rat des Bezirks, the MTS, VEGs and the technical colleges 
in Erfurt and Eisenach. Among their main tasks was analysis of the constitution and working style of local government and the effectiveness of relations between the LPGs and the district and village state apparatus. ${ }^{25}$ In the reports of these groups, there was damning criticism of the way in which the staff in the Rat des Kreises and the village mayors treated the LPGs in the district. The charge of 'liberalism' was directed at state functionaries who had clearly done little to prevent farmers from abandoning collective practices and farming individually.

The closing report on the activities of the investigating brigade in Kreis Nordhausen from the end of September 1960 paints a picture of incompetence or at least inactivity from a surprisingly large number of local functionaries. Most seriously in the villages of Ilfeld and Niedersachswerfen, newly formed LPGs had been left entirely to their own devices. 'Liberalism' was considered to be widespread in the district apparatus, infecting leading SED members in the village as well as infecting the state village councils through to the MTS and the agricultural office of the SED Kreisleitung. The brigade's remedy for the situation in the village of Ilfeld, where it was thought an anti-collectivisation and an anti-regime sentiment was particularly virulent, demonstrated how far it thought the district authorities had allowed things to slip.

The brigade intervened forcefully. It altered the management of the LPG, removing the chairman from his post, and making an example of him in the newspaper as 'an enemy of the people'. The LPG Type I was then merged together with the Type II - with no suggestion here of any consideration given to a ballot of the members, as demanded in theory by the stipulations of 'collective democracy'.

In the district at large 120 instructors were deployed by the Rat des Bezirkes in the villages to put a stop to the inefficiency of MTS functionaries and village mayors, a small number of whom had to be sacked. Given the lack of suitable replacements, however, the majority were upbraided and given instructions to be more assertive. ${ }^{26}$ In October 1960 all the state administrations in the districts - but especially in Kreise Apolda, Sömmerda, Heiligenstadt and Sondershausen - were highlighted in a report for having failed to have a direct influence on the new Type I and Type II LPGs. Along with the lack of suitable mayors, in some (MTS) regions in the districts it was noted for example that there was no one available to instruct the LPGs on how to organise their finances. In one MTS area the instructor was left with the impossible task of overseeing the work done in forty-six LPGs. ${ }^{27}$

Although troubleshooting brigades continued to operate in LPGs around the Bezirk, with the departure in early summer of the majority of the agitators for collectivisation, rejection of collective farming reas- 
serted itself in villages across the Bezirk. Open discussion of the intention to harvest individually was liable, if reported, to result in some form of investigation. However, there were limits to the ability or desire of local state functionaries to penetrate sufficiently what was taking place in the many small, new LPGs which had just been formed. In the Bezirk as a whole it was estimated that approximately 50 per cent of the newly founded Type I or Type II LPGs had failed to adhere to the model LPG statute during the harvest. ${ }^{28}$ It is likely, however, than the actual proportion was somewhat higher. Unless subjected to repeated close investigation, it could not necessarily be established whether farmers nominally in an LPG were continuing to farm independently of one another or not. Documentary evidence of the collective administration of the LPG - such as the fulfilment of plan requirements, division of profits according to work units and proportions of land - could be supplied to the relevant officials at local and district level without necessarily changing anything in practice. One LPG in Kreis Arnstadt managed to work in this way successfully for two years before being discovered. ${ }^{29}$

In some parts of the Bezirk, failure to adhere to the model statutes was the rule rather than the exception - illustrating clearly the impotence of the local outposts of regime authority. In 1960 almost all farmers in Type I LPGs in the districts of Heiligenstadt and Worbis, were reported to have harvested individually. ${ }^{30}$ It was clear that above all in these strictly Catholic rural areas, local village functionaries, including members of both the SED and CDU, were not able themselves to enforce the implementation of regime policy alone. Certainly in Kreis Heiligenstadt in early 1961, it was noted that even SED members still acted too much under the influence of priests and members of the church boards and were unwilling to destroy their relationships with family and friends by openly advocating the party line. ${ }^{31}$

Despite the shortage of ideologically and technically suitable local functionaries willing or able to enforce adherence to the statutes, the attempt was made to ensure that the size of the harvest would not be damaged and that LPG functionaries would be held to account for any severe drop in yields. Party members from rural SED organisations along with tractor drivers from the MTS were given the task of attending board meetings and members' assemblies of the LPGs throughout the harvest period. Wherever they reported an element of conflict or uncertainty about how (or rather according to whose rules) the harvest was to be brought in, representatives of the local party, the state apparatus, as well as leading figures from the MTS and factories which had been given responsibility for the political and material wellbeing of certain LPGs, were to intervene. They were to provide sufficient labour (bands of so- 
called 'harvest helpers') and agree a definite plan to ensure crops were harvested as quickly as possible regardless of LPG members' attitudes. ${ }^{32}$

Throughout the harvest season, operative committees based in the MTS as well as in the district administration oversaw the deployment of groups of several hundred auxiliary harvest workers and pressed mayors and LPG chairmen for progress reports. The impact of these operative committees varied from district to district, depending on the competence of the local and district functionaries themselves and on the reception their measures received from LPG members on the ground. These in turn were contingent to some extent upon the proximity of centres of SED authority and in part on the suitability of collective farming for local conditions. The agricultural authorities in Kreis Erfurt-Land in particular were praised by the Bezirk for having succeeded in organising on-site troubleshooting brigades in almost every village as early as the beginning of August 1960. Kreis Bad Langensalza was also reported to have been successful at organising the harvest through the operative committees. Further away from the Bezirk's arable heartland and the Bezirk's capital, however, the picture worsened. In Kreis Gotha it was noted that MTS functionaries were not forceful enough in persuading LPG members to adhere to deadlines and in Kreis Mühlhausen the harvest had only been brought in 'on time' thanks to the deployment of Soviet and East German Army (Nationale Volksarmee or NVA) troops as farm labourers. ${ }^{33}$

The stability of the supply of food was (particularly since the uprising of June 1953) felt at all levels of the SED to be tied directly to the stability of the GDR as a whole. This fact was precisely the reason for strict police control and for deep suspicion of, and potentially severe punishments for, serious drops in production levels. However, it was also the basis for a more limited repressive response to resistance to collective farming practices, where this did not immediately undermine production. The manner in which the campaign for full collectivisation had occurred undoubtedly cowed many of those who had opposed it farmers and functionaries alike. But farmers were not in an entirely powerless position. Not only was their active participation in collective practices necessary to the survival of the LPGs in the long term; in the short term farmers, along with the rest of the population, were in a position to vote with their feet and abandon the GDR.

\section{Flight to the West}

Up to the construction of the Berlin Wall, fleeing to the West, while still considered risky, was nonetheless an option chosen by a large number 
of farmers who felt that they had little to lose in abandoning the farm once collectivisation seemed inevitable. In addition, large numbers of young people saw no future in agriculture and hoped for better working conditions in the West. ${ }^{34}$ Month after month following collectivisation, LPG members constituted a significant proportion of those fleeing the GDR. In April and May 1960 seventy-eight LPG members, twentyseven employees of the MTS and the VdgB along with fifty-nine women and eighty-three children were recorded to have fled the Bezirk. In July and August 1960 a further 104 farmers are recorded as having fled the republic from Bezirk Erfurt. ${ }^{35}$

In the border areas of the Bezirk, especially in the northern Catholic Eichsfeld, whole villages that had close links with the population just across the border absented themselves. ${ }^{36}$ In one village in Kreis Apolda, three farmers fled with their families during the collectivisation campaign after having been denied the chance to set up an LPG on their own, separate to the one already established. ${ }^{37}$ As statistics on the numbers of people working in agriculture in Bezirk Erfurt who successfully fled to the West show, the culmination of the collectivisation process resulted in a sustained increase in flights during the summer months despite some small decline during the high point of the harvest season, when it might be assumed fewer dared to go unaccounted for. As in the rest of the GDR, numbers of people abandoning agriculture in the Bezirk to flee to the West did decline slightly during the autumn and winter of 1960. However, throughout the first half of 1961 the number of flights by LPG members in Bezirk Erfurt each month remained high. See Figure 2.1.

In the opinion of the SED Central Committee's Agriculture Department the reason for the rapid increase in flights was the basic neglect of the politics of the village by the district authorities following the conclusion of the collectivisation campaign. Even the Kreisleitungen of the SED were considered to be wholly incompetent on the question of illegal flights to the West. Sporadic attempts to investigate and analyse cases were made, but, the ZK department claimed, no systematic approach had been developed to deal with this growing problem. The situation was necessarily compounded by the relative inactivity of village functionaries. Notably mayors and local SED party secretaries failed to act on their own initiative, keeping track of and responding to cases of illegal flight to the West. ${ }^{38}$ Only, it seems, in cases where leading LPG functionaries had fled were major investigations launched. The flight of accountants from LPGs in Kreis Gotha and Kreis Erfurt-Land and of an LPG chairman in Kreis Sondershausen in January 1961 were taken very seriously on the grounds that they represented supposedly deliberate 


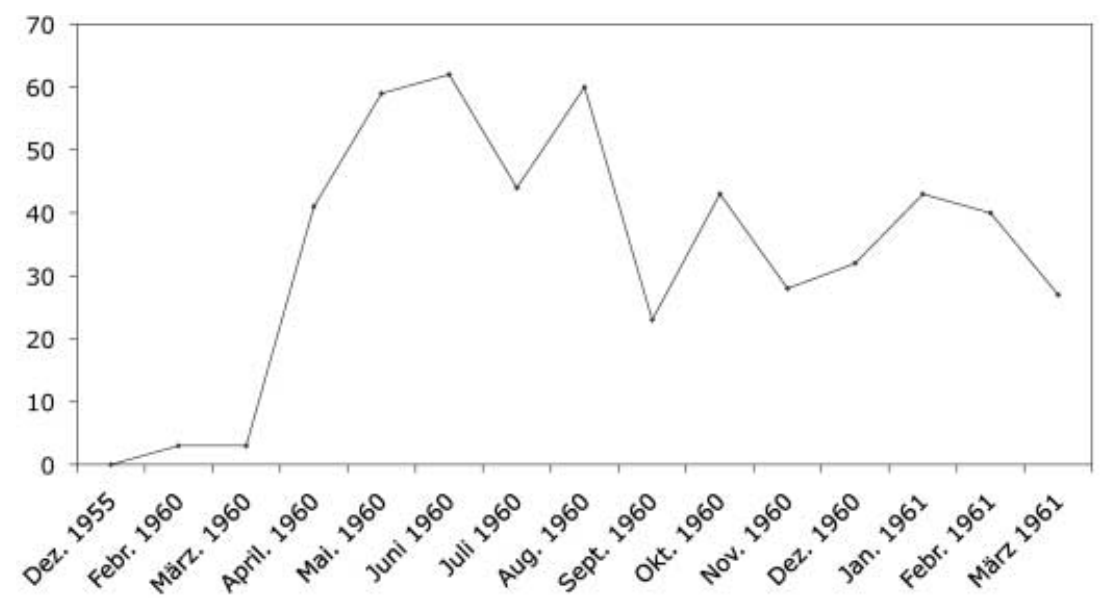

Figure 2.1 Illegal flights from the GDR by LPG members in Bezirk Erfurt, February 1960 to March 1961.

Source: SAPMO B-Arch DY30/J IV 2/3 J/190 ZK der SED - Sekretariat, Information der Abteilung Landwirtschaft beim ZK, Einschätzung der Republickflucht auf dem Gebiet der Landwirtschaft. April? 1961.

ploys to demoralise and arouse further discord amongst the remaining members of LPGs. ${ }^{39}$

The effect on agriculture of this steady exodus was certainly severe in some localities, with the task of managing abandoned farms falling to the often undermanned and underfunded LPGs. The parlous state of the buildings and land left behind, and the insufficiency of machinery and labour to farm such abandoned fields and look after livestock meant they were more of a burden than a boon to the LPGs. The threat to leave for the West and the potential to do so as long as security measures along the border were still relatively lax no doubt influenced how the collectives were seen by the LPG members and how they were treated by the hierarchy of state and party functionaries. On the one hand, while it was still possible to get out of the GDR, farmers did not necessarily think of abandoning their property for as long as they could still hope that changes would occur in international politics to reverse the situation. On the other hand, so long as the flow of farmers to the West could not be dammed by careful surveillance alone, it appears limits were set to the level of repressive action which could be taken against recalcitrant LPG members.

The Bezirk police authority (Bezirksbehörde der Deutschen Volkspolizei or BDVP) worked according to the supposition that there was massive 'hostile activity' in the LPGs in the aftermath of collectivisation; it was 
just a question of whether their officers were competent enough to recognise it. The range of potentially serious crimes for which individuals could be charged was sufficiently broad to intimidate most dissenting farmers into avoiding any virulent or public demonstrations of opposition. However, despite the guidelines, there was at times a clear gulf between the desired attitude of local police and what they were willing to do or capable of in practice. The local police constable (Abschnittsbevollmächtigte or $\mathrm{ABV}$ ) had considerable responsibilities for overseeing the consolidation of the LPGs, in exposing and reporting any actions by LPG members which could be construed as detrimental to the collective farm or indeed the state. Policemen at district and village level, however, had to be repeatedly criticised for failing to take 'class conflict' into account when investigating the situation in agriculture and rural communities.

The chief of the department for criminal matters in the district police office (Volkspolizeikreisamt or VPKA) for Kreis Arnstadt in November 1960 was criticised for attributing findings of livestock mortality, bad practice by state functionaries and problems in the LPGs to 'organisational' and 'objective' causes. The investigating brigade from the Bezirk police authorities (BDVP) pointed out that in so doing he had entirely neglected the question of class conflict. The brigade also reported that other officers in the department appeared too to have misunderstood the meaning of class conflict.

With a certain degree of logic, policemen argued that the completion of the collectivisation campaign had put an end to the existence of hostile classes in countryside. From this point of view, there was no longer a need to pursue class conflict as such in the countryside. ${ }^{40} \mathrm{~A}$ report by instructors on the work of the VPKA Eisenach in September 1960 commented, with what seems like sarcastic understatement, on the spectacular failures of police operations in the countryside:
Although in many villages in Kreis Eisenach collective work has not been implemented and the people themselves suggest that farmers are being influenced ideologically by western television and western radio; although livestock mortality is continuing to increase and the number of illegal flights from the Republic by people of interest to us has increased, there has so far been no success at uncovering hostile activity. ${ }^{41}$

A set of guidelines issued in April 1960 by the Interior Ministry to local police constables indicated which crimes they should expect and prepare to prevent in the newly fully collectivised villages and LPGs. Above all, production levels were to be maintained through careful vigilance against any form of sabotage, while young people were to be prevented from succumbing to hostile influences (presumably in a 
bid to prevent their flight to the West). ${ }^{42}$ Combating livestock mortality in particular was to be seen in the context of a class struggle in which almost any premature death could be construed as a deliberate act masquerading as neglect or incompetence from a member of an LPG.

Despite the suspicion with which instances of damage to crops and livestock were treated, it is debatable how much was deliberate sabotage. Potentially opponents of collectivisation might have wished to demonstrate the non-viability of an LPG by aggravating any negative consequences for agricultural production levels that had arisen. Potentially, too, farmers planning to flee the country might have had an interest in destroying their property before it was 'taken over by the state'. However, in the majority of cases which received serious investigation in Bezirk Erfurt, supposed acts of wanton destruction of crops or livestock could not be proven to have been the result of hostile intentions. ${ }^{43}$

Arguably the intention behind the scrutiny of instances of severe production losses was as much concerned with providing LPG members with an additional incentive - based on fear of arrest - to maintain production levels. Nonetheless acts of petty sabotage did occur in the LPGs, alongside less subtle demonstrations of hostility towards the LPG and the SED dictatorship in general, including threats and acts of violence against those who had supported collectivisation. In an extreme case, in a village in Kreis Eisenach in September 1960, it was reported that a loudspeaker car containing agitators was set upon by twenty-five to thirty people, one of whom threatened to set it on fire. ${ }^{44}$

While such acts were no doubt borne of frustration and despair, less extreme demonstrations of public opposition were arguably prompted too by some expectation that something might really be gained by them. Given the sense of uncertainty about the future status of Germany or doubts as to the permanence of collective farming, actions that undermined the LPG or demonstrated farmers' dissatisfaction were not necessarily considered to be vain gestures. In May 1960 a village mayor was reportedly asked whether 'he wasn't afraid if things were to change since what he has done to the farmers in recent weeks can't be made good and he is now hated by everyone ${ }^{\prime}{ }^{45}$ At an assembly in the LPG Type III Wasserthaleben in Kreis Sondershausen in May 1960 calls were made for the introduction of free elections, arguing that at least then farmers would not have to be in the LPG. ${ }^{46}$ Similarly, in an assembly of the LPG 'Fortschritt' ('Progress') in May 1960 in Kindelbrück, two farmers were cheered when they announced to representatives of the Rat des Kreises Sömmerda that they had been forced into the LPG. ${ }^{47}$

The first year after the end of the collectivisation campaign thus saw a tangle of recrimination, repression and conciliation, as farmers, LPG 
functionaries and local, district and regional representatives of the regime attempted to assert or protect their often all-too-divergent interests. While there was enough uncertainty with regard to the permanence of the collective farm and indeed the GDR itself, those who sought to limit the impact of the proclaimed collectivisation on the conditions in which they lived and worked were well provided with motivation and opportunity to do so.

\section{The Strength of Popular Dissent}

It was clear that the apparatus of agricultural administration from the (often reluctant) LPG functionaries and the (liberal) local and district state authorities right up to the SED leadership in Berlin was neither consistently able nor always willing in the first year after full collectivisation to take repressive action to control widespread disregard for collective farming. At the same time throughout 1960 rumours spread regularly throughout the countryside in Bezirk Erfurt that collectivisation might soon be abandoned, that the Americans might return to Thuringia or, more vaguely, that 'things will be different soon' ${ }^{48}$ In Gierstädt, Kreis Erfurt-Land, some farmers reportedly even raised the spectre of the 17 June 1953 uprising, stating that on this date in 1960 something would happen which would help farmers get their land back. ${ }^{49}$ Against this background of uncertainty and instability, the potential benefits of resisting collectivisation, whether by openly rejecting it or more carefully subverting it, outweighed the potential repercussions.

In the initial weeks and months after the completion of the collectivisation campaign, a wave of withdrawals from the LPGs came from those farmers who had recently been pressured into joining. ${ }^{50}$ The right to withdraw from the collective had been initially allowed for in the statutes of all types of LPGs. In theory any departure had to be voted on by the membership and entailed the return of only an equivalent-sized piece of land on the edge of the LPG. Nevertheless LPG members made use of this right to withdraw, reclaiming their own land in spite of the statute. The lack of an explicit law making refusal to participate in an LPG illegal had added to the grievances of private farmers required to sign declarations of 'voluntary' entry. In this context withdrawal was an equally 'voluntary' refusal to participate in the LPG any longer.

The reports detailing the flow of withdrawals indicate that in the vast majority of cases, sufficient pressure and persuasion could be brought to bear to induce membership to be taken up again. However, conflicts were not always quickly resolved. During the first year after the comple- 
tion of the collectivisation campaign new instances of withdrawal from the LPG were registered periodically in different parts of the Bezirk, amounting to as many as 640 in 1960 - of which only 200 had been persuaded to take up membership again by the following year. ${ }^{51}$ Two reports - one from the beginning and one from the end of July 1961 demonstrate the ongoing struggle faced by district functionaries. At the start of the month fifty-seven withdrawals were recorded from LPGs in the Bezirk, in addition to forty-seven withdrawals from gardening collectives in the area of Erfurt-Stadt alone. At the end of the month 199 withdrawals are recorded, with outbreaks in districts which had previously registered none. In only ninety-four cases had members been successfully persuaded to return to the LPG by the end of the month. ${ }^{52}$ Rumours that in the autumn of 1961 the LPGs would be dissolved were clearly motivation enough for farmers to take the initiative to withdraw again in early 1961 and, in the Type I LPGs, to terminate contracts on the use of privately owned machinery. ${ }^{53}$ In Kreis Worbis in at least nine villages, LPGs appeared to be on the verge of disbanding in July $1961 .{ }^{54}$

A less confrontational means of protest against and subversion of collectivisation was to limit the extent of one's active participation. Given that the LPGs relied upon the manpower of formerly independent farmers as well as use of their land, tools, machinery and livestock, it was possible to undermine their economic stability very effectively by contributing as little as was possible - within the bounds of the law. Farmers would not allow their barns to be used by the LPG, and were slow to make their machinery available, amid suggestions that they might need them themselves soon. ${ }^{55}$ In the LPG 'Aufbau' ('Construction') in Torba, Kreis Sondershausen, whose chairman had noted that 70 per cent of the members opposed the collectivisation, the police reported: 'a poor work ethic currently predominates here - this is to be seen in the fact that some members have been sick for a fortnight already and no sick notes have been handed in'. ${ }^{56}$ It was also common to refuse to work overtime or on weekends. ${ }^{57}$

Particularly prevalent in police reports too is the deliberate neglect of collective land, while conversely great lengths were taken to look after household plots and livestock. Owing to circumstances in Poland where some collective farms had been allowed to dissolve because they had proved too much of an economic burden for the state, in spring 1961 rumours spread that the same measures might be taken in the GDR if the situation became bad enough. On the basis of this some farmers devoted more effort to strengthening their household farms while allowing the LPG's land to go untended. ${ }^{58}$ During the 1961 spring cultivation period in Kreis Sondershausen, farmers were found to have 
abandoned planting on collective land in a number of LPGs owing to the poor weather. They had instead either gone straight to the local pub or off to tend their private land. ${ }^{59}$

In other LPGs, members simply stayed away from work or worked half-heartedly, expectant of change in the not-too-distant future. Shortly before the building of the Berlin Wall in the summer of 1961 rumours were rife in parts of the Bezirk that something momentous was about to change the entire political situation in Germany. In Tiefthal, Kreis Erfurt-Land, the CDU mayor reacted to plans to build a communal laundry with the words: 'What's the point of that when everyone is going to get all his stuff back anyway?' In the village of Witterda in Kreis ErfurtLand a large number of LPG members had stopped going to work at the end of July 1961, responding to the rumoured instruction: 'Work slow, it will be different soon.' ${ }^{60}$

More directly in contravention of the statutes, no action was taken to reorganise or amalgamate fields or transfer livestock into collective sheds. In the upland districts of the Bezirk in particular, farmers resisted moves to amalgamate fields - a state of affairs which local state functionaries reportedly did little about. ${ }^{61}$ LPG members failed to divert a proportion of the profits into a common fund - a fundamental requirement for the LPG's future investment in the tools of industrial production as foreseen by socialist agricultural policy. In other areas, adherence to the statute was not enforced within the LPG, compromises being reached in members' assemblies over aspects of pay and work organisation and the allocation of land for members' gardens and private plots. In the LPG Type I in Wechmar, Kreis Gotha the members decided to share profits simply according to the amount of land contributed to the LPG, with each member receiving the same wage. This was done on the basis that each member would work 'normally' and that there was no need therefore to differentiate. ${ }^{62}$

Without the participation of the LPG members in record keeping, the value of the LPG as a means of forcing improved labour productivity and of integrating agricultural production more efficiently into the planned economy was considerably reduced. In several LPGs there were simply no records kept of the numbers of livestock kept in the LPG, or indeed the numbers which had died or been slaughtered. ${ }^{63}$ Members of Type I LPGs, too, reportedly sought to prevent outside interference in the way they distributed profits by failing to keep records of the work done by members or of the amount of produce they had received as payment in kind. Thus it was difficult to work out a system of performance-related pay or assess exactly what had already been paid out to the members and thus what should be accumulated as capital by the collective. Equally, without effective records of production levels 
and turnover, it was difficult for the members to commit to raising their plan targets for the coming year. ${ }^{64}$

The strength of dissent was considerable, and remained so while neither collectivisation nor the GDR's future seemed certain. Nevertheless, as an institution the LPG could not be discounted. Farmers were confronted constantly by the existence of the LPG as the administrative body within which they were organised - indeed through which they were now defined as citizens - even in those parts of the country where the collective farm existed in name only. The longer LPGs survived, so the gradual (and often inconsistent and uncomprehensive) application of administrative pressure made them an unavoidable part of the reality of farming in the GDR.

\section{The Seeds of Consolidation in the LPG}

During September 1960, the SED Bezirksleitung sent further brigades into the Type I LPGs within the Bezirk. The tasks set them were considerable: 'implementation of the statute and the establishment of internal work ordinances; the introduction of socialist principles of work and performance; realisation of collective democracy; the formation of commissions to establish work norms and performance related pay; creation of the preconditions necessary for collective livestock holdings; and guidance in the creation of a production and finance plan for 1961. ${ }^{65}$ Given the small amount of time (three weeks) and the enormity of the tasks facing these brigades, it is not surprising that there continued in 1961 to be many Type I LPGs in which aspects of collective farming failed to be adopted.

Nevertheless the passing of the harvest and the relative quiet of the winter months in agricultural terms provided opportunities for farmers and LPG functionaries to take stock of the situation. The desire to rebel against collectivisation certainly continued to exist; however, the LPG as an institution, though hugely flawed, continued to survive too and in so doing grew slowly in stature and permanence. Farmers were certainly still fleeing to the West, but the majority who remained increasingly had to reconcile themselves to the fact they only had a status within the LPG. In order to sell their produce, earn an income and improve the conditions in which they lived and worked, there was no alternative other than participating in the structures of the collective farm.

The beginning of the new year saw the holding of the main yearly assemblies in the LPGs. These assemblies - being held for the first time in approximately half of the Bezirk's LPGs - were a crucial test of how far attitudes of LPG members, particularly new ones, had changed over 
the year. That LPG members were willing to attend the assembly and at least listen to discussions was some sign that the LPGs were recognised as the institution through which action might be taken and their interests articulated. Reports on the discussions held during the assemblies of the LPGs of Types I and II, especially those of the new LPGs, referred to the concentration of the discussions on resolving local problems affecting the community, and avoidance of any ideological or political commentary on the merits of collective farming. In an LPG in Bad Tennstedt Kreis Bad Langensalza in March 1961, farmers walked out of the members' assembly during the political speeches of leading Bezirk functionaries who had attended as guests, reportedly commenting: 'When that fellow in there has finished babbling, we'll go back in to the assembly. ${ }^{\prime 66}$

Nevertheless, advocates of collective farming - whether LPG functionaries or local representatives of party and state - were also clearly winning (or enforcing) some acceptance of, if not support for, the statutes of the LPGs. There were reports of discussions in LPG Type I on whether to change the ratio of income from 60:40 to 70:30 in favour of work units over land contribution for the coming year. The question of whether meadows and grazing land would be better tended collectively was also raised. Furthermore it was reported that almost all LPGs of Types I and II in Bezirk Erfurt had diverted 15 per cent of the farm's profits into an investment fund. ${ }^{67}$ Perhaps still more significantly, LPG members in a proportion of Type I LPGs were reported to be backing the restriction of the number of animals and land granted to the wealthier farmers. In other words, LPG members themselves were acting to redistribute the sources of income in their collective more evenly. This suggests if not ideological acceptance of the LPG then at least some practical acceptance of its existence and a willingness to use its structures in their own interests. With the new year came further impetus for the consolidation of LPGs - at least administratively speaking: reluctant members could no longer reasonably claim the right to harvest individually and it was increasingly difficult for LPG members to separate their interests from those of the LPG as an institution. The allocation of unjust plan targets to the LPG by the Rat des Kreises in early 1961 was now a matter of concern for all, even reluctant, members of the collective farms. ${ }^{68}$

\section{Conclusion}

In the first year after full collectivisation major initial steps were taken in the reorganisation of agricultural production. The LPG had been intro- 
duced and no longer remained a distant possibility but rather increasingly appeared to be a permanent feature of agriculture in the GDR as long as the current regime remained. Despite the numerous setbacks and failures of the first year after full collectivisation, with farmers resistant and functionaries incapable or unwilling to implement collective practices, limited success had been achieved in consolidating the LPG as a lasting, potentially stable institution. ${ }^{69}$ It was clear, however, that whatever successes had been achieved in reconciling farmers to the LPG, the future development of agriculture in the GDR was by no means certain.

\section{Notes}

1. ThHStAW BDVP 20/044 Politabteilung, VPKA Eisenach Einschätzung der Feindtätigkeit im Kreis Eisenach, 9.9.1960.

2. ThHStAW BDVP 20/065 BDVP Stab/Operativstab, Information 17/60 Argumente und Gerüchte, 23.3.1960: 'Eintritt in die LPG bedeutet Enteignung und Aufgabe des freien Bauern, man wird kommandiert.'

3. Gesetz über die Landwirtschaftlichen Produktionsgenossenschaften, Gesetzblatt der DDR I/36, 3.6.1959; Musterstatut für Landwirtschaftliche Produktionsgenossenschaften Typ I \& Typ III, Gesetzblatt der DDR I/26, 9.4.1959.

4. Officially the quota was as follows: up to 2 cows with calves, 2 sows with offspring, 5 sheep with 5 lambs and an unlimited amount of goats, poultry, rabbits and other small animals, as well as 10 beehives.

5. This was measured in work units (Arbeitseinheiten or AE), calculated according to norms which reflected the expertise, time and effort required to do various jobs around the farm.

6. See for example the anonymous threat by farmers to Werner Felfe, the Politburo member responsible for agriculture in 1982: 'for approximately thirty years we have been waiting for the payment of the additional inventory contribution brought into the LPG. So now you as a powerful man get moving on this. This is what the farmers of not just the northern Bezirke expect.' SAPMO BArch DY 30/294 Büro Werner Felfe, Anonyme Eingabe an Herrn Felde: 'Wie man uns sagte ...' 14.5.1982.

7. ThHStAW Bezirksparteiarchiv der SED Erfurt, Bezirksleitung der SED Erfurt BIV/2/4-103 BPKK, Aktennotiz - Betr: Lage im Kr. Sömmerda, Bezug: Mitteilung der staatlichen Kontrolle über Feindtätigkeit im Kr. Sömmerda, 6.10.1960: 'Es herrscht das Argument vor: “Das fremde Zieg (Zeug) muss raus!"'

8. ThHStAW BDVP 20.1/352 BDVP Operativstab, Information 53/61, 8.6.1961, p. 30.

9. ThHStAW RdB Erfurt L562 Rat des Bezirkes Erfurt, Abt. Landwirtschaft, Unterabteilung LPG, Einschätzung der politischen und ökonomischen Entwicklung der LPG des Bezirkes Erfurt, 5.10.1962. 
10. ThHStAW Bezirksparteiarchiv der SED Erfurt, Bezirksleitung der SED Erfurt BIV/2/4-58 SED Kreisleitung Sömmerda an die BPKK, Erfurt, Feindarbeit im I. Quartal 1961, 17.4.1961, p. 169.

11. BStU Aussenstelle Erfurt, Kreisdienststelle Weimar 379, Abschrift Analyse Gemeinde Daasdorf am Berg, 11.10.1961, p. 70.

12. ThHStAW BDVP 20/065 BDVP Stab/Operativstab, Information 25/60, Auswertung der Vorkommnisse in der Landwirtschaft zur Beurteilung der Lage, 20.5.1960.

13. ThHStAW RdB Erfurt L590 Rat des Bezirkes Erfurt, Abt. Landwirtschaft, Einschätzung der Entwicklung der LPG des Typ I im Bezirk Erfurt, 6.7.1960.

14. ThHStAW BDVP 20/247 VPKA Erfurt Operativstab, Berichterstattung an die BDVP über die polizeiliche Lage bei der soz. Umgestaltung der Landwirtschaft, 18.7.1960.

15. ThHStAW BDVP 20/065 BDVP Stab/Operativstab, Information über Vorkommnisse in der Landwirtschaft 19/60, 4.5.1960.

16. ThHStAW BDVP 20/065 BDVP Stab/Operativstab, Information 36/60, Einschätzung der Lage in der Landwirtschaft, 20.7.1960; Information über vorkommnisse in der Landwirtschaft 19/60, 4.5.1960.

17. ThHStAW BDVP 20.1/352 BDVP Operativstab, Information 62/61 Landwirtschaft, 5.8.1961, p. 43.

18. ThHStAW BDVP 20/065 BDVP Stab/Operativstab, Auswertung der Vorkommnisse in der Landwirtschaft 20/60.

19. ThHStAW RdB Erfurt L562 Rat des Bezirkes Erfurt, Abt. Landwirtschaft Unterabteilung LPG, Einschätzung der politischen und ökonomischen Entwicklung der LPG des Bezirkes Erfurt, 5.10.1962.

20. ThHStAW Bezirksparteiarchiv der SED Erfurt, Bezirksleitung der SED Erfurt IV/2/3-328 Sekretariat der Bezirksleitung, Vorlage, An das Büro der Bezirksleitung: Bericht über den Einsatz der Brigade der Bezirksleitung im Kreis Apolda, 2.5.1960, pp. 6-16.

21. ThHStAW Bezirksparteiarchiv der SED Erfurt, Bezirksleitung der SED Erfurt IV/2/3-328 Sekretariat der Bezirksleitung, Beschluss Protokoll, Beitrag Genosse Asmus, pp. 17-19.

22. ThHStAW Bezirksparteiarchiv der SED Erfurt, Bezirksleitung der SED Erfurt IV/2/2-322 Sekretariat der Bezirksleitung, Beschluss-Protokoll Nr. 10/60 der Sekretariatssitzung, Fernschreiben von der SED Bezirksleitung an alle 1. Kreissekretäre, 21.3.1960, p. 140.

23. ThHStAW Bezirksparteiarchiv der SED Erfurt, Bezirksleitung der SED Erfurt IV/2/3-338 Sekretariat der Bezirksleitung, RdB Erfurt Abt. Land, Erf u. Forst: Bericht über die Durchführung des Maisanbaukontrolle vom 2530.6.60 im Bezirk Erfurt, 13.7.1960, pp. 115-17.

24. ThHStAW RdB Erfurt L590 Rat des Bezirkes Erfurt, Abt. Landwirtschaft Einschätzung der Entwicklung der LPG des Typ I im Bezirk Erfurt, 6.7.1960.

25. ThHStAW Bezirksparteiarchiv der SED Erfurt, Bezirksleitung der SED Erfurt IV/2/3-335 Sekretariat der Bezirksleitung Konzeption für den Einsatz der Brigade zur Verbesserung der staatlichen Leitungstätigkeit auf dem Gebiete der Landwirtschaft, 4.7.1960, pp. 57-58. 
26. ThHStAW Bezirksparteiarchiv der SED Erfurt, Bezirksleitung der SED Erfurt IV/2/3-338 Sekretariat der Bezirksleitung, Protokollauszug - Sekretariatssitzung - Brigade in Nordhausen, 18.7.1960, p. 22; Bezirksparteiarchiv der SED Erfurt, Bezirksleitung der SED Erfurt IV/2/3-348 Sekretariat der Bezirksleitung, Brigade Nordhausen der Bezirksleitung Abschlussbericht über den Brigadeeinsatz im Kreis Nordhausen, 28.9.1960, pp. 77-87.

27. ThHStAW RdB Erfurt L562 Rat des Bezirkes Erfurt, Abt. Landwirtschaft, Unterabteilung LPG, Einschätzung der politischen und ökonomischen Entwicklung der LPG des Bezirkes Erfurt, 5.10.1962.

28. ThHStAW RdB Erfurt L562 Rat des Bezirkes Erfurt, Abt. Landwirtschaft Unterabteilung LPG, Einschätzung der politischen und ökonomischen Entwicklung der LPG des Bezirkes Erfurt, 5.10.1960.

29. ThHStAW RdB Erfurt L590 Rat des Bezirkes Erfurt, Abt. Landwirtschaft, Einschätzung der Entwicklung der LPG des Typ I im Bezirk Erfurt, 6.7.1960.

30. ThHStAW RdB Erfurt L562 Rat des Bezirkes Erfurt, Abt. Landwirtschaft Unterabteilung LPG, Einschätzung der politischen und ökonomischen Entwicklung der LPG des Bezirkes Erfurt, 5.10.1962.

31. ThHStAW Bezirksparteiarchiv der SED Erfurt, Bezirksleitung der SED Erfurt BIV/2/4-59 SED Kreisleitung Heiligenstadt an die BPKK, Einschätzung über die Feindarbeit im Kreis im 2. Quartal 1961, 30.6.1961, p. 455.

32. ThHStAW Bezirksparteiarchiv der SED Erfurt, Bezirksleitung der SED Erfurt IV/2/3-335 SED Bezirksleitung Abt. Landwirtschaft an das Sekretariat, Informatorischer Bericht über den Tag der Erntebereitschaft, 4.7.1960, p. 5.

33. ThHStAW Bezirksparteiarchiv der SED Erfurt, Bezirksleitung der SED Erfurt IV/2/3-345 SED Bezirksleitung Abt. Org/Kader, Einschätzung der Bürositzungen vom 2.9.1960 und Ablauf der Halmfruchternte, 13.9.1960, p. 86.

34. ThHStAW Bezirksparteiarchiv der SED Erfurt, Bezirksleitung der SED Erfurt BIV/2/4-58 SED Kreisleitung Sondershausen an die BPKK, Erfurt, Bericht 15.4.1961, p. 160.

35. ThHStAW BDVP 20/065 BDVP Stab/Operativstab, Information über Vorkommnisse in der Landwirtschaft 28/60, 21.6.1960; ThHStAW Bezirksparteiarchiv der SED Erfurt, Bezirksleitung der SED Erfurt IV/2/3-345 Sekretariat der Bezirksleitung, Abt. f. Sicherheitsfragen: Bericht über die Republikflüchte, Rückkehrer, Erstzuziehenden und die legalen Verzüge im Monat August 1960 in Gegenüberstellung zum Vormonat, 13.9.1960, p. 133.

36. BArch DP 1, Nr. 1134 Ministerium des Innern an den Minister der Justiz, Information zur Lage bei der soz. Umgestaltung der Landwirtschaft in Auswertung des Massnahmeplans zum VIII Plenums des ZK der SED für die Zeit vom 19.6. bis zum 11.6.1960, p. 10.

37. ThHStAW BDVP 20.1/361 VPKA Apolda, Abt. S. Analyse über die Klassenkampfsituation der Gemeinde Stobra, ?.4.1961, p. 161.

38. SAPMO BArch DY30/J IV 2/3 J/190 ZK der SED - Sekretariat, Information der Abteilung Landwirtschaft beim ZK, Einschätzung der Republikflucht auf dem Gebiet der Landwirtschaft, April? 1961. 
39. ThHStAW RdB Erfurt L591 Rat des Bezirkes Erfurt, Abt. Landwirtschaft Bericht an die Bezirksleitung der SED, Sekretariat, Stand der Jahresabrechnungen, Rechenschaftslegungen und Neuwahlen in den LPG Stichtag, 1.2.61, 3.2.1961.

40. ThHStAW BDVP 20/044 BDVP Politabteilung, Bericht über den Brigadeeinsatz im VPKA Arnstadt in der Zeit vom 8.11.-12.11.1960, 26.11.1960.

41. ThHStAW BDVP 20/044 BDVP Politabteilung, Bericht über den Instrukteureinsatz im VPKA Eisenach vom 14.9.-23.9.1960, 30.9.1960.

42. ThHStAW BDVP 20/081 BDVP Stab/Operativstab Arbeitshinweise zu den Aufgaben der Volkspolizei in den vollgenossenschaftlichen Dörfern auf der Grundlage der Direktive des Ministers des Innern Nr. 4/60, 19.4.1960.

43. ThHStAW BDVP 20/065 BDVP Stab/Operativstab, Information 39/60, 26.7.1960.

44. ThHStAW BDVP 20/044 Politabteilung, VPKA Eisenach, Einschätzung der Feindtätigkeit im Kreis Eisenach, 9.9.1960.

45. ThHStAW BDVP 20/065 BDVP Stab/Operativstab, Information über Vorkommnisse in der Landwirtschaft 19/60, 4.5.1960.

46. ThHStAW BDVP 20/044 Politabteilung, VPKA Eisenach, Einschätzung der Feindtätigkeit im Kreis Eisenach, 9.9.1960.

47. ThHStAW BDVP 20/065 BDVP Stab/Operativstab, Information über Vorkommnisse in der Landwirtschaft 24/60, 20.5.1960.

48. ThHStAW BDVP 20/065 BDVP Stab/Operativstab, Information 36/60, Einschätzung der Lage in der Landwirtschaft, 20.7.1960.

49. ThHStAW BDVP 20/065 BDVP Stab/Operativstab, Information 32/60, 6.7.1960.

50. ThHStAW BDVP 20/065 BDVP Stab/Operativstab, Information 41/60, Vorkommnisse in der Landwirtschaft, 26.7.1960.

51. ThHStAW RdB Erfurt L591 Rat des Bezirkes Erfurt, Abt. Landwirtschaft, Bericht an die Bezirksleitung der SED Sekretariat, Stand der Jahresabrechnungen, Rechenschaftslegungen und Neuwahlen in den LPG Stichtag, 1.2.61, 3.2.1961.

52. ThHStAW RdB Erfurt L591 Rat des Bezirkes Erfurt, Abt. Landwirtschaft, Unterabteilung LPG, Informatorischer Bericht über Austritte aus den LPG und GPG, 5.7.1961; Abt. Landwirtschaft, Erfassung und Forstwirtschaft, Unterabteilung LPG, Einschätzung der Austrittserklärungen aus den LPG und GPG im Bezirk Erfurt, 31.7.1961.

53. ThHStAW BDVP 20.1/352 BDVP Operativstab, Information 51/61 Austrittserklärungen und Funktionsniederlegungen, 25.7.1961, p. 27.

54. ThHStAW BDVP 20.1/352 BDVP Operativstab, Information 58/61 Landwirtschaft, 28.07.1961, p. 38.

55. ThHStAW BDVP 20/065 BDVP Stab/Operativstab, Information 44/60 Vorkommnisse in der Landwirtschaft, 8.8.1960.

56. ThHStAW BDVP 20/065 BDVP Stab/Operativstab, Information 68/60 Vorkommnisse in der Landwirtschaft, 9.11.1960.

57. T. Bauer, Blockpartei und Agrarrevolution von Oben: Die DBD, 1948-1963, Munich, 2003, pp. 506-7. 
58. ThHStAW Bezirksparteiarchiv der SED Erfurt, Bezirksleitung der SED Erfurt BIV/2/4-58 SED Kreisleitung Sondershausen an die BPKK, Bericht 15.4.1961, p. 160.

59. ThHStAW BDVP 20.1/352 BDVP Operativstab, Information 51/61, 1.6.1961, p. 25.

60. ThHStAW BDVP 20.1/352 BDVPOperativstab, Information 59/61, 29.07.1961, p. 40.

61. ThHStAW BDVP 20/081 BDVP Stab/Operativstab, Information 59/60 Vorkommnisse in der Landwirtschaft, 12.10.1960; BDVP, Lagebesprechung am 14.10.1960 zur Einschätzung der Feindtätigkeit auf dem Lande, 17.10.1960.

62. ThHStAW RdB Erfurt L590 Rat des Bezirkes Erfurt, Abt. Landwirtschaft, Einschätzung der Entwicklung der LPG des Typ I im Bezirk Erfurt, 6.7.1960.

63. BArch DE 1, Nr. 12164 Zentrale Kommission für Staatliche Kontrolle - Der Vorsitzende, Informationsbericht Nr.7, 1.3.1961, p. 87; Zentrale Kommission für Staatliche Kontrolle - Der Vorsitzende, Bericht: Bezirk Erfurt - Unrealer Nachweis über Rinderverluste durch die Organe der Zentralverwaltung für Statistik, 1.3.1961, p. 103.

64. ThHStAW Bezirksparteiarchiv der SED Erfurt, Bezirksleitung der SED Erfurt IV/2/3-362 Sekretariat der Bezirksleitung Abt. Landwirtschaft: Informatorischer Bericht über den Stand der Plandiskussion mit dem Stand vom 3.2.1961, 4.2.1961, pp. 8-13; BDVP 20/247 VPKA Erfurt, Abt. K - Komm.SE: Bericht über Verbrechen in den Ortsschaften an der Fernverkehrsstrasse IV, 5.8.1960.

65. ThHStAW Bezirksparteiarchiv der SED Erfurt, Bezirksleitung der SED Erfurt IV/2/3-345 SED Bezirksleitung Abt. Landwirtschaft an das Sekretariat, Einsatz von Studenten und Fachschülern zur Unterstützung der LPG besonders des Typ I im Bezirk Erfurt, p. 46.

66. ThHStAW Bezirksparteiarchiv der SED Erfurt, Bezirksleitung der SED Erfurt BIV/2/5-10 SED Bezirksleitung Abt. Org./Kader, Zwischenbericht über die Arbeit der Brigade in Bad Tennstedt, pp. 267-73.

67. ThHStAW Bezirksparteiarchiv der SED Erfurt, Bezirksleitung der SED Erfurt IV/2/3-362 Rat des Bezirkes Erfurt, Abt. Landwirtschaft an die SED Bezirksleitung, Stand der Jahresendabrechnungen, Rechenschaftslegungen und Neuwahlen in den LPG - Stichtag, 1.2.1961, 3.2.1961, pp. 32-39.

68. ThHStAW NF 275 Kreissekretariat Erfurt-Land, Betr. Tel. Durchsage vom 7.2.1961, 8.2.1961, p. 9.

69. The transfer of some heavy machinery from the MTS to Type III LPGs in the fertile flatlands of the Bezirk, above all in Kreis Bad Langensalza, Weimar and Sömmerda, had proved beneficial in considerably improving the profitability of a number of collective farms - for example, ThHStAW RdB Erfurt L615 Rat des Bezirkes Erfurt, Abt. Landwirtschaft, Erfassung und Forstwirtschaft, Ergebnisse der bisher an die LPG Typ III leihweise übergebenen Technik und Schlussfolgerungen für die weitere Ubergabe, 22.6.1961. 


\section{of 3}

\section{FARMING BEHIND THE WALL}

You just want to dominate us, there are so many who think for us now why so much pressure, we will manage things just as we do every year. ${ }^{1}$

(The complaint of farmers in Kreis Arnstadt in September 1962 as functionaries from the district administration sought to control the harvesting of crops.)

On 13 August 1961 the obstacles to an illegal departure from the GDR to West Germany were suddenly made considerably more severe. Along with the Wall running through Berlin, measures were taken to strengthen security along the entire border with West Germany, a considerable part of which ran along the northern and western edges of Bezirk Erfurt. Although attempts continued to be made to get across the border by citizens of the GDR - with some limited success in the first weeks after the Wall's construction - the steady flow of people to the West was brought to an abrupt halt. This brought to an end the drain on manpower and expertise from the GDR, which was severely undermining the East German economy as well as any claims the SED regime made to legitimacy. With the economic security lent by the Wall, the prospects for the survival of the GDR under SED dictatorship improved significantly.

This security lent the leadership of the SED greater self-confidence in pursuing radical and often unpopular policies and taking punitive action against those it considered hostile. However, it also encouraged East Germans as a whole to reassess how to make the best of their lives within the SED dictatorship now that they were deprived of the possibility of an alternative life in the West and the likelihood of reunification had receded significantly. It thus ensured that a much increased proportion of the population reconsidered their future in the GDR and were moved to participate in it and in so doing sustain and shape the structures and systems of authority by which the SED dictatorship was run over the coming years. There is no doubt that the construction of the Wall was thus a major turning point in the GDR's social and economic development and had an impact, in both the short and long term, on the way in which the authority of the SED leadership was communicated and understood within East German society. 
In the past, flight to the West had certainly not been an easy option that citizens of the GDR had taken lightly. This was perhaps especially so for farmers where an inherited or long-standing connection and sense of responsibility to the land, to their livestock and to their community could act as an additional restraint on the desire to leave the country. Nonetheless a very large proportion of the population, many of them farmers, had deemed the risks and losses involved in flight to the West worthwhile. For those farmers who had thus far remained in the GDR despite collectivisation, departure to the West had thus always been a potential alternative to remaining in the LPG. The complete locking of the border removed this alternative, bringing stability and greater certainty as to the long-term survival of the LPG. The subsequent forcible resettlement of 'unreliable' villagers away from the border regions also made clear the limits of opposition and the lengths of repression possible in the GDR. Now that the SED leadership could afford to be less tolerant, the test of conscience, loyalty and obedience put to farmers and rural functionaries during the collectivisation campaign was reapplied from August 1961 with still less room for dissent and greater incentive to support the consolidation of the LPG.

\section{The Limits of Dissent}

Public outbursts of resentment directed towards the regime or the LPG continued to occur in Bezirk Erfurt despite the construction of the Wall. Swastikas were graffitied on LPG buildings and in instances in 1961 and 1962 in Kreis Heiligenstadt manure was spread on a field in such a way that a swastika became apparent in a darker shade of green, making it visible for miles around. ${ }^{2}$ There were now, however, very severe repercussions for any LPG members suspected of deliberately hindering the successful development of collective farming. There had certainly been instances of draconian punishments meted out for acts of supposed economic sabotage against the LPG before August 1961. On a national level the death penalty was applied and publicised in two cases of arson both before and after the construction of the Wall. ${ }^{3}$ Nevertheless the more secure position of the SED leadership after 13 August 1961 immediately allowed the stricter application of ideological discrimination both within the ranks of the regime's own apparatus and among the population at large.

Communities within the $5 \mathrm{~km}$ exclusion zone along the Bezirk's border with the Federal Republic were subjected to a sudden crackdown on 'hostile' elements. In part because of the strength of religious affilia- 
tion in the border areas of the Catholic Eichsfeld and in part because of the proximity of the West, villages in this area were suspected of being potentially dangerous hotbeds of enemy agents and sympathetic reactionaries. ${ }^{4}$ Individuals and families deemed politically unreliable - not least on the basis of their behaviour during the collectivisation campaign and the degree of their acceptance of the LPG - were forcefully deported in early October 1961 with little or no warning. The brutality and, in a large number of cases, the arbitrary nature of these actions sent a clear signal of the ruthlessness with which the regime was willing to go about consolidating its authority in rural communities. ${ }^{5}$

In some cases seemingly arbitrary expulsions provoked attempts by villagers to have the decision revoked. Petitions were signed and sent to the Central Committee of the SED in Berlin - these had very little success, however. Rather such evidence of unchecked negative opinion towards the regime resulted in further investigations by the Stasi and the SED Party Control Commission not only into those involved in the petition but also into those village functionaries who had failed to act against it on the ground. ${ }^{6}$ The virulence of the SED regime's actions against sections of the population in the border areas succeeded in demonstrating the potential repercussions of any future behaviour that might be construed as hostile to the state. This no doubt limited any potential support which those who sought to flee the GDR received from locals in the border regions. No less significantly, it also raised the spectre of forced resettlement as a possible punishment for 'hostile' villages elsewhere in the Bezirk, as one villager in Kreis Bad Langensalza pointed out: 'with the actions on the border, it would not be long before people in Reichenbach will be expelled too'.

During late summer in 1961 action was taken, in the words of the Ministry for Agriculture in Berlin, to 'unmask hostile and counterrevolutionary forces in the village'. Public confrontations were staged with numerous farmers, above all those who had been local agricultural functionaries under the Nazis (Ortsbauernführer), as well as other Nazi party members and Wehrmacht officers, resulting in a number of arrests or restrictions on their movements. The crackdown on such elements of the rural population resulted, it was claimed, in immediate improvements to the labour discipline and the work ethic of LPG members. Villagers generally had become more active in their 'confrontations with hostile and unprogressive forces in the villages and LPGs'. Moreover, several thousand farmers around the country who had up until then continued to farm individually had been moved to 'participate actively in the collective'. Nevertheless, for all the confidence and authority lent the regime's apparatus by the construction of the Wall, there were still 
considerable limitations on the scale of the confrontation with 'hostile forces' which could be mounted in rural communities. Local functionaries could not always be relied upon to pursue the class conflict with the degree of zeal required. Nonetheless, it is likely that the construction of the Wall itself and the exemplary punitive action which followed, targeted particularly against those who could be easily identified as having 'reactionary tendencies', had a monitory effect on the rural population - LPG members included. ${ }^{8}$

According to district police reports from around Bezirk Erfurt, even minor acts or expressions of anti-GDR and anti-LPG sentiment in villages were punished severely, especially if they were combined with other evidence of a reactionary attitude such as a Nazi past or regular watching of Western television. ${ }^{9}$ One farmer in Bad Sulza who had in previous months come to the attention of the police for his 'hostile attitude' was now given a one-year prison sentence for ripping down a GDR flag from a sports ground..$^{10}$ In a particularly severe case, action was also taken against religious opposition to the collectives, which was hampering progress particularly in Catholic areas. A Catholic lay preacher was arrested and sentenced to as much as four years' imprisonment, charged with having persuaded a number of board members in LPGs across the Bezirk to give up their posts. ${ }^{11}$

The potential for a criminal and ideological interpretation to be applied by the police and Justice Ministry to almost any circumstance which undermined collective farming or damaged productivity was a strong incentive for farmers to disassociate themselves from any manifestations of hostility towards the LPG. Outbreaks of disease or sudden death among livestock, damage to crop stores caused by fires and even petty vandalism or damage to LPG property tended to be classed as the result of 'enemy activity', and where the 'perpetrators' were identified, very severe punishments could be handed out. According to police reports from February 1962, one LPG member in Kreis Mühlhausen was sentenced to four and a half years' hard labour for mistreating and neglecting the cows in his charge, thereby contributing to livestock losses. ${ }^{12}$ In Heringen, Kreis Nordhausen, the LPG chairman and two members of the board were arrested for 'consistently hostile activities'. Alleged to have once been active Nazis, they were held responsible for 'consciously' causing a high livestock mortality rate in the LPG and thereby bringing about the failure of the LPG to fulfil its market production quota. In one case, an LPG member was sentenced to fourteen months' imprisonment for not declaring the full number of potatoes which were in his possession, farming other villagers' small plots of land for them and declaring that he had been forced into the LPG. ${ }^{13}$ 
That the new climate had an impact on collective farmers themselves can be seen in the attitude expressed by the district shepherd in Kreis Weimar when faced with a severe shortage of feed for the animals in his charge. In a report by a Stasi informant on an assembly in the LPG Type III Legefeld held in January 1962, the shepherd was heard to comment that: 'he knew from experience the police would hold him responsible and he wasn't going to let himself be locked up for this!'14

With the construction of the Wall came new legislation enabling serious punitive action to be taken against farmers who refused to work in the collective. Classified as 'work-shy' and truants, they could be sentenced to serve in a labour-education camp if they chose to resist the 'will of the majority' and refused to work for the LPG. The number of farmers actually punished on this charge is not clear, given the ambiguous legal position of those who withdrew from LPGs. ${ }^{15}$ Nevertheless police sources in Bezirk Erfurt do refer to a few, seemingly exemplary arrests where LPG members were known consistently to refuse to work for the collective farm. For example, a farmer in Hohenfelden, Kreis Weimar-Land was reported to have been put under arrest for truancy. He had failed to do more than a few days' work in the LPG since the previous year and had encouraged other members to do likewise. ${ }^{16}$

Action also began to be taken against those LPG members who were thought to maintain an excessive household plot or private livestock and thereby earn an income without participating fully in the LPG. A report by the District SED Party Control Commissions (Kreisparteikontrollkommission or KPKK) in Kreis Arnstadt and in Kreis Langensalza in December 1961 discovered one farmer in the LPG Type III Arnstadt who was allegedly earning over 15,000 Marks a year for produce from his private plot and livestock, while farming 1.4 hectares rather than the 0.5 hectares officially allowed him. ${ }^{17}$ Police also investigated an LPG Type III in Kreis Sondershausen where it was revealed that a large proportion of the members gained incomes from private production that were significantly higher than their incomes from the collective. Of the sixty-three members, only thirty ever appeared for work in the LPG on a regular basis, while twenty-nine of the men had completed less than one hundred work units in the year. ${ }^{18}$

That such situations should have arisen is demonstrative of the limits to which functionaries of the LPG or indeed the local state authority had been able or willing to curtail abuses of the statute up to this point. The construction of the Wall and the escalation thereafter of punitive action against those who appeared to be undermining collective farming began to create a new climate in which the limits to dissent were clearly marked. With this background LPG functionaries stated 
clearly the connection between the limited success of the LPG and the behaviour or attitude of recalcitrant members who preferred to work on their private land and contributed little time to the LPG. The Rat des Bezirkes reported approvingly, for example, of an LPG in Kreis Arnstadt where farmers who had completed few work units were addressed by name and house number during the main annual members' assembly in 1962, shaming them with the censure of their neighbours. ${ }^{19}$ Similarly local committees of the National Front also sought wherever possible to publicise the efforts or lack of them of individual members of the collectives. Agitation groups addressing farmers in 1962 came thus armed with information on how much each one had contributed to the fulfilment of the plan. ${ }^{20}$

With the realisation that there was little benefit in opposing the LPG and few if any alternatives to working within it, many new and reluctant collective farmers accepted their LPG as the institution within which they would be allowed to earn a livelihood, and set about working for its profitability. One collective farmer in Kreis Heiligenstadt reportedly admitted that he had been among those who sought to hinder the development of the LPG. He claimed, however, to have changed his mind and considered it in his own and everyone else's better interests to make the LPG work. ${ }^{21}$ How far such realisations were widespread is difficult to gauge. Nevertheless, instances of a general 'go slow' attitude did clearly diminish as acceptance of the LPG increased during 1962. Many more LPG members thus began to work effectively as collective farmers, within the framework laid out in the LPG statutes. ${ }^{22}$

There is no doubt that the building of the Wall and the subsequent crackdown diminished the level of overt hostility towards collective farming, particularly among those farmers who objected to the LPG on principle. It was certainly an important step too towards raising the level of acceptance of the LPG as the essential framework in which the land was farmed. However, while there remained little evidence of the benefits of collectivised agriculture, rural communities continued to be marked too by outbursts of popular dissatisfaction, not least because fear of financial destitution remained very real for some collective farmers.

\section{Sources of Continued Instability}

The pay and conditions for large numbers of LPG members, particularly those in LPG Type IIIs, appeared to have little prospect of improving in 1962, resulting in demonstrations of discontent at the start of the new year. For 1960, the state guaranteed an annual income of 3,120 
Marks for each LPG member working full time, which corresponded approximately to a work unit value of 6 Marks. ${ }^{23}$ This amount was considerably lower, however, than most considered reasonable compensation for the difficulty of the work they put in and the restrictions preventing them seeking better-paid work elsewhere. A member of the LPG Type III 'Fortschritt' in Kindelbrück made this clear to representatives of the Rat des Kreises Sömmerda in May 1960, shouting out at the members' assembly: 'You yobs, food-stuffed officials, you're alright for money. We're not going to be kept quiet with promises. We want the work unit to be paid at 7 Marks. ${ }^{24}$

At the end of 1960 there were at least 126 Type III LPGs in the Bezirk which were officially deemed loss-making. Although this was considered a marked improvement on the previous year, the value of the work unit in most Type III LPGs remained barely more than the minimum. In the upland districts the situation was particularly dire: 63 per cent of Type IIIs in Kreis Mühlhausen and 54 per cent in Kreis Heiligenstadt continued to be financially unviable. ${ }^{25}$ This already difficult situation was compounded further in 1961 when heavy rainfall in the Bezirk in May and June promised to do serious damage to the first fully collective harvest. ${ }^{26}$ By the end of the harvest in 1961 - thanks to a combination of bad weather and the disruption resulting from collectivisation and the flight of farmers to the West - the gross production of crops in Bezirk Erfurt had reached only 71 per cent of the 1958 level, ${ }^{27}$ prompting comments such as the parodying slogan 'Mit Regen und Gott geht die LPG Bankrott' ('With the help of God and rain, the LPG goes down the drain') ${ }^{28}$ From all appearances the rush for full collectivisation had failed to bring about the dramatic rise in production that had been a prime motive for its introduction.

The poor harvest exacerbated the difficulties faced by LPG chairmen in mediating the demands of the state, while maintaining some degree of harmony among their members. It is unsurprising that some LPG chairmen threatened to resign if the production plan targets set for their LPG were not lowered. Not only would failure to exceed plan targets reduce the price paid for produce by the state, it would also mean the LPG members received a smaller portion of the produce for their own use. ${ }^{29}$ In September 1961 in Bezirk Erfurt, all collective farmers were required to allow inspection of their private stores of potatoes and allow a portion of them to be bought by the state to ensure the requirements of the population as a whole were well covered. ${ }^{30}$ The actual extraction of produce from LPG members' stores appeared to some collective farmers as an incontrovertible demonstration of their second-class status in the GDR and gave grounds for hostility towards local state functionaries 
required to oversee this process. In the village of Mellingen, Kreis Weimar, it was rumoured for example that the mayor and the ABV were receiving a bonus for every sack of potatoes they could collect from farmers. The complaints of LPG members were clearly born out of frustration with the lack of options available to them to resist (what they considered) unfair treatment. According to a report by an informant for the Stasi in Mellingen, some LPG members had indeed attempted to conceal some of their potatoes. On being discovered, one was reported to exclaim: 'Why don't you just take the whole lot and give me a train ticket to Bonn.' ${ }^{31}$ This way out was of course now barred. Those who felt aggrieved by the state's treatment of them had little choice other than to make their protests within the bounds of their current situation.

At the end of 1961 LPG accountants assessed the impact of the year's harvest on the financial status of collective farms. The state of affairs in Type III LPGs in the Bezirk was dire. In Kreis Mühlhausen alone Type III LPGs had to be subsidised by 1,400,000 Marks to bring members' incomes up to the minimum level, which itself was considered a famine wage..$^{32}$ In the Bezirk as a whole 50 per cent of Type III LPGs had required subsidies in order to be able to pay their members the minimum value of the work unit. When the value of the work unit was publicly announced in each of the LPG assemblies at the start of the new year, there was, unsurprisingly, considerable disgruntlement. In Kreis Bad Langensalza members of a number of LPGs complained openly about the money which they were to receive, while elsewhere in the district slogans were graffitied in LPGs such as: 'We work cheaper than coolies', 'SOS we want money' and 'Work slow'. ${ }^{33}$

The ones most directly affected by the LPGs' low profits were those machine operators and former industrial workers who did not supplement their regular income from the LPG with their own livestock or household plot and relied exclusively on being paid in monthly advance instalments for their work over the year. Faced by the failure of the LPG to provide a sufficient income and discussion of a possible state directive to LPG chairmen to limit the amount paid out in monthly advance wage instalments, a number of LPG Type III members sought to show their dissatisfaction. ${ }^{34}$ Professional tractor drivers - who had been moved to join the LPG from the MTS with the transfer of machinery and former industrial workers, many of them SED members, held work stoppages and sought officially to withdraw their membership of the LPG in protest. ${ }^{35}$ Between 12 December 1961 and 15 January 1962, the Bezirk police authority recorded at least 162 withdrawal declarations. ${ }^{36}$ In February 1962 at least 101 attempted withdrawals were registered from LPGs in the Bezirk. ${ }^{37}$ 
Where in previous years withdrawal had represented an act of resistance to the end of private farming and was a reaction against surrendering land into the collective, in 1962 it represented more a matter of protest at the poverty of working for the LPG - primarily by those who had not contributed land in the first place. A report from the Rat des Bezirkes in November 1962 notes the tendency of members of weak LPGs in Kreis Mühlhausen and Nordhausen to threaten withdrawal during discussions over rates of payment. ${ }^{38}$ Similarly in an LPG Type III in Kreis Heiligenstadt, a large proportion of the members threatened withdrawal unless they continued to receive the state subsidies required to increase the income level..$^{39}$ Withdrawal or the threat to do so was more a means of drawing attention to perceived injustices within the LPG and gaining the required investment to raise wages than a serious attempt to oppose the continuation of collective farming. ${ }^{40}$

The Bezirk Police Authority's political department, reporting on the role of the ABV in that year, stressed that 1962 was the year of transition in agriculture whereas 1963 would be the year of 'normality'. ${ }^{41}$ Certainly there were still numerous instances in the Bezirk at the start of 1962 where police investigations were deemed necessary as collective farmers not only protested but appeared also to be attempting to subvert or manipulate the structures of the LPG. The Ministry for State Security began an investigation in early 1962 into the LPG Type III in Trügleben, Kreis Gotha, after only three LPG members were found to have attended the annual members' assembly. ${ }^{42}$ Elsewhere secret ballots for the election of the collective farm's managing board prompted police investigations, especially where fewer SED members were selected for these positions than had previously been the case. Odd cases also came to light where the members' assemblies were held secretly in the private home of the chairman, deliberately to prevent local state or party functionaries from attending. ${ }^{43}$ In Kreis Nordhausen state functionaries attending an LPG assembly found themselves having to talk down 'negative elements' who were strongly opposed to SED agricultural policy. More seriously in the LPG Type I Niederzimmern in Kreis Weimar, plans to vote out of office the current LPG chairman - the only SED member in the collective farm - and replace him with someone else had to be stopped by the intervention of the SED Kreisleitung and the Rat des Kreises. ${ }^{44}$

Throughout the spring, troubleshooting brigades continued to operate around the Bezirk and agitators were deployed on certain festival days to encourage farmers to adhere to the state demands for increased planting of certain unpopular crops or to develop collective practices further. At the end of February, in Kreis Nordhausen alone, in one day 
as many as 1,200 agitators were at work. ${ }^{45}$ At the same time, a tense atmosphere clearly continued to exist in many rural communities. In March 1962 suggestions seemed to be made during the VII German Farmers' Congress that the boards and functionaries of Type I and II LPGs might be given access to the private bank accounts of their members in order to enable the purchase of machinery from the state. This sparked rumours of obligatory contributions to the funds of the LPGs being removed from farmers' bank accounts, with police reporting a panic rush by farmers to withdraw money from banks throughout April 1962 in Kreise Weimar, Worbis and Sondershausen. ${ }^{46}$ If nothing else, there remained an atmosphere of considerable mistrust in LPGs as to what new means the SED state might employ to reduce farmers' control of their own resources or at least short-change them for the use of their labour.

Two years on from the completion of the collectivisation campaign and a year on from the construction of the Berlin Wall, the situation in the various LPGs in Bezirk Erfurt continued to be highly variable. There had been a general reduction in outright opposition to or even subversion of collective farming and indeed an increase in the acceptance of the collective farm as an institution with a long-term future. Acceptance of the LPG as the only means through which it would be possible to secure a livelihood and a willingness to work for the prosperity of the farm were not necessarily reflected, however, in a harmonious relationship with the regime's apparatus for running agriculture. There remained a considerable degree of mistrust among farmers that the state was in the process of finding new ways to underpay (largely Type III LPGs) or expropriate them further (largely Type I LPGs). At the same time, the huge pressure for collectivised farming to prove itself and for the 1962 harvest to be successful, after the difficulties of the previous years, coupled with the uncompromising confidence of sections of the regime apparatus since the building of the Wall, made for continued confrontations.

\section{Confrontation and Control}

The collectivisation campaign itself had been characterised from the regime's perspective as an assertion of the science of socialist necessity over the conservative selfishness of farmers. However, a potent basis of opposition to the collectivisation in practice, if not in principle, was the demonstrable proof that it damaged production. The organisational turmoil of 1960 and 1961 left a large number of fields uncultivated and while this was clearly the result of the manner of the collectivisation 
and not the notion of collectivised agriculture in itself, the resulting low production figures were grist to the mill of those who had opposed the process in the first place. As farmers in Kreis Nordhausen pointed out, 'with so many fields uncultivated, things cannot go on like this'. ${ }^{47}$

In those LPGs where farmers had been compelled, in the interests of larger plantations of crops, to fill dividing ditches and remove hedging between fields, opposition to the LPG found still further vindication. Farmers blamed the collective farming system for exacerbating the effects of the bad weather in 1961. Heavy rains had caused widespread damage to fields and because the intervening ditches had been removed between the various plots, it was argued, the water could not drain, thus preventing any attempts to recultivate the soil. ${ }^{48}$

Even as the LPGs became more stable, there was still a clear gulf on numerous farming issues between socialist agricultural policy and farmers' own sense of good practice. The methods already initiated during the 1950s to improve the levels of livestock in the LPGs rapidly and raise the overall productivity of the GDR in meat and dairy products above that of the FRG - namely the extensive cultivation of low-maintenance maize as a feed crop and the construction of large yet inexpensive open sheds (Offenställe) for more concentrated livestock holdings - had had only limited success. In the opinion of many farmers they also clearly contradicted received wisdom and good practice. The construction of Offenställe had too often been seen to have disastrous consequences for livestock. Use of shoddy materials and poor choices of location exposed the animals kept in them to poor conditions. ${ }^{49}$ In extreme weather, such conditions in these sheds too easily became fatal to livestock. Investment was thus wasted on livestock and on buildings that ultimately were of little value.$^{50}$ Discussions among voluntary auxiliary policemen from across the Bezirk at a conference in April 1961 highlighted Offenställe as a particular cause of irritation in the LPGs. The report of this meeting indicates too, however, the resistance of the Bezirk functionaries present to recognising this problem. Despite the insistence of these voices from below, the discussion was closed with the remark: 'Offenställe will continue to be built and we will learn from the experiences we collect. ${ }^{.1}$

Erwin Strittmater's popular novel Ole Bienkopp, published by the East German Aufbau Verlag in 1964, controversially confronted directly some of the problems associated with the Offenställe and the frustration of LPG farmers upon whom they were imposed:

Yes this Offenstall! Did it fly into the [LPG] 'Blooming Field' on a magic carpet in order to unleash controversy? Not at all. It all really and truly happened. 
Building Offenställe for cattle is a directive from up top. From heaven? No, no but perhaps from the Ministry. Directives aren't issued out of sheer boredom! Milk makes money! Lots of cattle! Cheap sheds!

Are Offenställe cheap? They're made of wood, they're light and quick to transport. That's been proved.

Has it been proved that cows feel at ease in a shed built in the form of a theatre stage and milk as briskly as they would in a warm solidly constructed shed? No answer.

Perhaps the building of Offenställe is just a recommendation, but recommendations become commands by the time they have reached the village. Various employees of the district administration call village mayors their long arms. From the construction of Offenställe will be gauged whether the long arms are responding in a modern and progressive way.

At conferences village mayors ask one another: 'Well, how's your Offenstall?'

'It's still standing.'

'How are the cows doing?'

'I said: it's still standing!'

Good, the Offenstall is still standing and the district's statisticians can record it, count it and report it present. ${ }^{52}$

The imposition of maize as a feed crop was also not well received amongst the GDR's farmers. The cultivation of maize had been adopted by the Soviet Union, mimicking the U.S.A., as a safe means of producing reasonably high quality feed in large quantities, which could be cheaply and easily harvested with machinery if planted over large enough expanses. Thus, in turn, farmers in the GDR were initially encouraged to 'learn from the Soviet friends' and later then directed to devote a certain proportion of land to cultivating maize. In meeting these directives, LPG functionaries found themselves required to go against their own knowledge of the suitability of the land for this purpose. Even though the effectiveness of the maize crop was compromised by insufficient silage capacity in most LPGs, arguments were ignored in favour of traditional feed crops. As a result the number of animals sustainable was overestimated and led naturally to shortages of quality feed..$^{53}$

Although maize came gradually to be recognised by farmers as an essential part of the diet of livestock, at the start of 1962 in some Type I LPGs the size of maize plantations was still being hotly debated. The Rat des Bezirkes insisted that a minimum of 12 per cent of the arable land of an LPG be used for cultivating maize to ensure feed stocks were sufficient to prevent a repeat of the shortages arising from the previous year. LPG members continued, however, to refuse to use this much land for maize production, arguing that they themselves had enough pasture land to ensure their own livestock were well fed - come what may. ${ }^{5}$ 
The greater self-confidence of the regime a year after the construction of the Wall and two years after the completion of the collectivisation campaign was reflected in the treatment of collective farmers during the harvest in 1962. During the heightened pressure of the harvest period, district state and party functionaries sought more than ever to assert their authority over collective farmers. The crucial point of contention remained how in particular this harvest was to be conducted with mistrust apparent as to the effectiveness of the methods and the true motives of farmers and functionaries alike.

The arguments were finely balanced. On the one hand, the state administration claimed to be able to maximise the cost-efficiency and productivity of the harvesting, collection, storage and distribution of crops if the whole process was run according to a strict timetable on a sufficiently large scale. This claim, however, did not always ring true, seeming to be at times a thin veil for the exertion of authority by the administration, at the expense of the interests of LPG members. As one field brigade leader asked a delegate from the Rat des Kreises in Kreis Apolda: 'What sort of bonus are you getting for putting us under all this pressure? ${ }^{\prime 55}$ On the other hand, farmers reasonably claimed to know best when their crops ought to be harvested, how long it would take them and what was possible with the machinery available in practice, especially when faced with state or party officials who had little or no agricultural training. As the accountant in one LPG in Kreis Apolda put it: 'the comrade functionaries should let the farmers get on with their work and not set down regulations ... ${ }^{\prime 56}$ Nevertheless, the superiority of modern machinery and equipment for drying, storing and distributing crops in theory refuted the need to follow the traditional, local rules on what and when to plant and harvest and what the weather would be. Farmers' objections to the interference of the regime's representatives could thus at times be disregarded as part of an unhealthy regard for tradition and an unfounded suspicion of modern methods, as well as a simple hostility towards the SED state.

Confrontations occurred in a number of LPGs particularly where district and MTS functionaries insisted upon measures to speed up the harvest. In Kreis Apolda a brigadier was abused and threatened with the Stasi by the director of the MTS for refusing to allow grain to be harvested just after it had rained. Although the brigadier was motivated by a desire to maximise the yield and prevent it from rotting in storage, the MTS director regarded the delay as an unnecessary - and costly - interruption to the progress of the harvest machines under his command. ${ }^{57}$ Still more common were disputes over the state's deployment in collective farms of outsiders (students, school children and factory workers 
from the towns) to 'help' with the harvest. LPG members opposed such measures, claiming that such helpers were not only unnecessary, but also would not do the job well and would undercut farmers' incomes. In one LPG in Kreis Gotha, it was reported that two women farmers opposed the arrival of the harvest helpers from the town, suggesting, presumably with reference to bygone years, that the workers 'had only come because they were hungry'. As a result of such antipathy some LPG chairmen sent the helpers away, pointing out too that they would not be able to offload their entire crop if they harvested too quickly. ${ }^{58}$ Despite the various instances of LPGs rejecting help, the Bezirksleitung registered a total of 50,000 harvest helpers deployed during the harvest in the Bezirk, recruited both locally and in the towns and factories of the region. There was a documented tendency of the district authorities to overestimate these figures. Nevertheless they appear to have been successful at imposing helpers on LPGs in large numbers. ${ }^{59}$

District functionaries' moves to speed up the harvest against the better judgement of LPG chairmen and collective farmers provoked considerable irritation in some places. A police report in late September noted 'widespread discussion among farmers that the pace of the harvest is too quick and that instructions are being given by functionaries of the Rat des Kreises which are causing damage to the LPG'. The chairmen of an LPG in Schwobfeld, Kreis Heiligenstadt was quoted, bitterly pointing out that 'LPG members would have to keep their mouths shut and the gentlemen from the Rat des Kreises decide when the grain is to be brought in' ${ }^{60}$ Board members in the LPG Aschara Kreis Weimar complained that 'everything was being dictated from above', while the chairman of the LPG Wolfsbehringen complained that the SED ‘had no need to concern itself with everything' ${ }^{61}$

Such matters concerned not only ordinary farmers and LPG chairmen but also, at times, local functionaries of party and state who could see only the negative impact of bureaucratic interference where it took precedence over local and practical understanding of the situation. A report from September 1962 noted that leading local SED members and village mayors openly spoke out against SED policies and in some cases sought to resign their positions in protest. The mayor of Gamstädt was reported to have argued that it was no good setting administrative campaign targets during the harvest. Rather, he argued, it should be left up to the farmers to set their deadlines. Even a leading member of the SED Kreisleitung Mühlhausen, concerned by the situation in his home village, argued against any action that might jeopardise the quality of the harvest for the sake of saving time. ${ }^{62}$ The mayor of Herbsleben, Kreis Bad Langensalza even reportedly asked to resign, saying the 
measures of the party were 'stuff and nonsense' ('Käse und Quatsch'). Other leading village functionaries, among them SED members, were openly hostile to outside interference. In nearby Henningsleben, a leading member of the SED party organisation was reported saying during a meeting: 'We should be out working not holding discussions. Next year we should plant five hectares of clubs and with them thrash all the functionaries who come out here. ${ }^{63}$

Such comments were indicative of the extent of local irritation at the interference of the district authorities and the unnecessary dictates of the SED leadership. They were made too with some justification. At the beginning of 1963 an assessment was made of the numbers of LPGs still struggling in the Bezirk and those that had improved sufficiently to be classed as financially stable. Of the 175 LPGs counted in 1962 as 'left behind', eighty-four had improved. However, a further twenty LPGs had sunk into financial difficulty during the year, leaving the net total of struggling LPGs in the Bezirk at 111, approximately one in ten. ${ }^{64}$ Moreover, with the results of the harvest only marginally better than in previous years, collective farmers continued to show their dissatisfaction with the LPG by seeking to withdraw from it. ${ }^{65}$

\section{Conclusion}

With the removal of lingering doubt over the future existence of the GDR, a degree of coherence had been lent to previously fragmented collective farms. Moreover, farmers had been made well aware of the limits of dissent. However, there had been no consistent and comprehensive stabilisation of the LPG, either financially or politically, while the bullying tactics of the 1962 harvest had shown themselves only of limited value and were in some cases literally counter-productive. Despite the security gained by the SED regime through the construction of the Wall, farmers in both Type I LPGs and Type III LPGs remained thus hostile to further state intervention in agriculture. Collectivisation in the vast majority of LPGs was by the end of 1962 far more than just collectivisation on paper. However, the SED leadership's prospects of gaining consistent and comprehensive control over the conduct and development of agricultural production at the grass roots were severely limited, not least by the deficit of ideological support for socialism and the lack of confidence in socialist agricultural policy among collective farmers and LPG functionaries alike.

The next section deals with the conflicts, compromises and consensus of interests that developed between collective farmers and the func- 
tionaries of the LPG and the party and state administration in Bezirk Erfurt during the 1960s. It will show how attempts to reform the financial and agricultural organisation of collectivised farming were shaped by the changing circumstances in which SED policy was communicated and received in the LPG. In the next chapter, I shall look back in particular to the beginnings of a drive to increase the proportion of farmers who had received technical training since the late 1950s and the attempts to extend the network of SED party organisations into the LPGs both before and after the construction of the Wall, as part of the gradual transformation of the context in which SED agricultural policy was implemented on the ground in the farms of Bezirk Erfurt.

\section{Notes}

1. ThHStAW Bezirksparteiarchiv der SED Erfurt, Bezirksleitung der SED Erfurt BIV/2/7-557 Bericht der Arbeitsgruppe die in Arnstadt zur Ernte eingesetzt ist, 10.9.1962, p. 20.

2. ThHStAW BDVP 20.1/241 BDVP Kripo an die Hauptverwaltung der Deutschen Volkspolizei, Hauptabteilung K, Abt. U. Berlin, Brennpunktmeldung für den Monat Mai 1962, 28.5.1962, p. 376.

3. F. Werkentin, Politische Strafjustiz in der Ara Ulbricht, Berlin, 1995, pp. 106-9.

4. ThHStAW Bezirksparteiarchiv der SED Erfurt, Bezirksleitung der SED Erfurt BIV/2/4-59 SED Kreisleitung Heiligenstadt an die BPKK Einschätzung über die Feindarbeit im Kreis im 2. Quartal 1961, 30.6.1961, p. 455; BPKK, Information über die Feindarbeit im Bezirk entsprechend den vierteljährlichen Berichten der KPKK, 17.7.1961, p. 400.

5. BArch DP 1, Nr. 1152 Ministerium der Justiz, HA II, Hauptverwaltung Deutsche Volkspolizei - Operativstab, Rapport Nr. 275, 5.10.1961 and Nr. 276, 6.10.1961.

6. For example ThHStAW Bezirksparteiarchiv der SED Erfurt, Bezirksleitung der SED Erfurt BIV/2/4-59 KPKK Nordhausen, Bericht über Feindarbeit im IV. Quartal 18.12.1961, p. 79.

7. ThHStAW Bezirksparteiarchiv der SED Erfurt, Bezirksleitung der SED Erfurt BIV/2/4-59 KPKK Bad Langensalza, Bericht über Feindarbeit im IV. Quartal, 13.12.1961, pp. 62-67.

8. SAPMO BArch DY30/IV 2/7/376 Ministerium für Landwirtschaft, Erfassung und Forstwirtschaft, Einschätzung der Entwicklung der Lage auf dem Lande in Vorbereitung der Wahlen zum 17.9.1961, pp. 65-70.

9. BStU Aussenstelle Erfurt, Kreisdienststelle Weimar 379, Analyse über die Gemeinde Legefeld, 11.10.1961, p. 62.

10. ThHStAW Bezirksparteiarchiv der SED Erfurt, Bezirksleitung der SED Erfurt BIV/2/4-59 SED Kreisleitung Sondershausen an die BPKK, Einschätzung über einige Erscheinungen im Kr. Sondershausen, 25.9.1961, p. 344; KPKK Erfurt-Land, Bericht über Feindarbeit im III. Quartal, 25.9.1961, p. 
222; KPKK Mühlhausen, Bericht über Feindarbeit im III. Quartal, 26.9.1961, p. 300.; SED Kreisleitung Apolda an die BPKK, Bericht über Feindarbeit im III. Quartal, 29.9.1961, p. 135.

11. ThHStAW Bezirksparteiarchiv der SED Erfurt, Bezirksleitung der SED Erfurt BIV/2/4-59 SED Kreisleitung Worbis an die BPKK, Quartalsbericht über Feindarbeit im III. Quartal, 29.9.1961, p. 379.

12. ThHStAW BDVP 20.1/352 VPKA Mühlhausen, Abt. $\mathrm{K}$ an den Leiter des VPKA, Einschätzung der Lage in der Landwirtschaft im Kreisgebiet, 5.2.1962, p. 154.

13. ThHStAW Bezirksparteiarchiv der SED Erfurt, Bezirksleitung der SED Erfurt BIV/2/4-59 SED Kreisleitung Nordhausen an die BPKK, Einschätzung über den Umfang und die Wirkung der Feindarbeit im Kreisgebiet Nordhausen im III. Quartal 1961, 28.9.1961, p. 310; KPKK Arnstadt, Bericht über Feindarbeit im IV. Quartal, 21.12.1961, p. 2; SED Kreisleitung Apolda an die BPKK, Bericht über Feindarbeit im IV. Quartal, 20.12.1961, p. 10.

14. BStU Aussenstelle Erfurt, Kreisdienststelle Weimar 379, GI 'Max' Bericht über die Jahresendversammlung der LPG Legefeld, Abschrift 2.2.1962, p. 33.

15. BArch DP 2, Nr. 1272 Oberstes Gericht, Entwurf - Beschluss des Plenums des Obersten Gerichts zur Anwendung der Verordnung vom 24.8.1961 ... Anordnung der Arbeitserziehung, p. 6: 'Fundamentally not work-shy are those who have proper employment. If a citizen with proper employment is repeatedly absent from work and unexcused, it is necessary to examine why this is the case.'

16. ThHStAW Bezirksparteiarchiv der SED Erfurt, Bezirksleitung der SED Erfurt BIV/2/4-59 KPKK Erfurt-Land , Bericht über Feindarbeit im III. Quartal, 25.9.1961, p. 222; SED Kreisleitung Weimar-Land an die BPKK, Informatorischer Bericht über Feindarbeit im Kreis Weimar-Land im Zusammenhang mit den Sicherheitsmassnahmen vom 13.8.1961, 9.9.1961, p. 360.

17. ThHStAW Bezirksparteiarchiv der SED Erfurt, Bezirksleitung der SED Erfurt BIV/2/4-59 KPKK Arnstadt, Bericht über die Feindarbeit im IV. Quartal, 21.12.1961, p. 2; KPKK Bad Langensalza, Bericht über die Feindarbeit im IV. Quartal, 13.12.1961, p. 62.

18. ThHStAW RdB Erfurt L52 BDVP Operativstab, Information 6/62 Landwirtschaft, 9.1.1962.

19. ThHStAW RdB Erfurt L1153 Rat des Bezirkes Erfurt, Abt. Landwirtschaft, Informatorischer Bericht über den Stand der Jahresendabrechnung in den LPG am 29.1.62, 1.2.1962.

20. ThHStAW NF 126 Bezirkssekretariat, Referat zu der Entwicklung der Nationalen Front (undated) p. 61.

21. ThHStAW BDVP 20.1/352 BDVP Operativstab, Information: Vorkommnisse in der Landwirtschaft 18/62, 9.2.1962, p. 72.

22. ThHStAW RdB Erfurt L1153 Rat des Bezirkes Erfurt, Abt. Landwirtschaft Informatorischer Bericht über den Stand der Jahresendabrechnung in den LPG am 29.1.62, 1.2.1962.

23. This work unit value takes into account the amount deducted for payment in kind over the course of the year. To qualify for subsidies to ensure the income of members did not sink below 3,120 Marks, LPGs were required to 
keep to limits on the amount accumulated as capital and the number of work units performed by the members. ThHStAW L562 Rat des Kreises Worbis, Abt. Landwirtschaft, Analyse der Entwicklung der LPG hinsichtlich der Erfüllung der Produktions- und Finanzpläne im Jahre 1960, 20.2.1961.

24. ThHStAW BDVP 20/065 BDVP Stab/Operativstab, Information über Vorkommnisse in der Landwirtschaft 24/60, 20.5.1960.

25. ThHStAW RdB Erfurt L562 Rat des Bezirkes Erfurt, Abt. Landwirtschaft Bericht über die politische und ökonomische Entwicklung der LPG des Bezirkes im Jahre 1960, 27.2.1961.

26. D. Gabler, Entwicklungsabschnitte der Landwirtschaft in der ehemaligen DDR, Berlin, 1995, p. 118: in six Kreise 80 per cent of fields suffered some damage; ThHStAW RdB Erfurt L591 Rat des Bezirkes Erfurt, Abt. Landwirtschaft Einschätzung des Standes der Entwicklung der LPG, besonders der LPG Typ I und II im Bezirk, 1.7.1961; ThHStAW RdB Erfurt L1153 Rat des Bezirkes Erfurt, Abt. Landwirtschaft Begründung zur Erhöhung der Uberbrückungskredite re Ratsbeschluss Nr. 186-104/61 Undated (Nov. 1961); ThHStAW Bezirksparteiarchiv der SED Erfurt, Bezirksleitung der SED Erfurt, BIV/2/4-59 SED Kreisleitung Eisenach an die BPKK, Bericht über die Feindtätigkeit im Kreis Eisenach, 30.6.1961, p. 429.

27. Gabler, Entwicklungsabschnitte, p. 118.

28. ThHStAW BDVP 20.1/139 BDVP Stab/Operativstab, Information 56/61, 23.8.1961.

29. ThHStAW Bezirksparteiarchiv der SED Erfurt, Bezirksleitung der SED Erfurt BIV/2/4-59 SED Kreisleitung Gotha an die BPKK, Feindtätigkeit im Kr. Gotha im III. Quartal 1961, 29.9.1961, p. 275.

30. BArch DE 1, Nr. 29131 Zentrale Kommission für Staatliche Kontrolle - Der Vorsitzende, Informationsbericht Nr. 36, 10.11.1961; Beschluss des Politbüros über operative Massnahmen zur Sicherung der Versorgung mit einigen Nahrungsgütern und Futtermitteln, 13.3.1961.

31. BStU Aussenstelle Erfurt, Kreisdienststelle Weimar 772, GI 'Buchmann', Lageeinschätzung der Gemeinde Mellingen übergeben am 10.11.1961, 14.11.1961, pp. 91-94.

32. ThHStAW BDVP 20.1/352 BDVP Operativstab, Information 21/62, Vorkommnisse in der Landwirtschaft, 15.2.1962, p. 80.

33. ThHStAW RdB Erfurt L52 BDVP Operativstab, Information 11/62 Landwirtschaft, 26.1.1962.

34. BArch DK1, Nr. 928 Ministerium für Landwirtschaft, Erfassung und Forstwirtschaft, Protokoll über die Auswertung der bisherigen Durchsetzung des Beschlusses vom 18.1.1962 mit den Verantwortlichen für die Bezirke, 21.2.1962, pp. 218-26.

35. ThHStAW Bezirksparteiarchiv der SED Erfurt, Bezirksleitung der SED Erfurt BIV/2/5-43 SED Bezirksleitung Abt. Org./Kader, Einschätzung der MV in den PO der Landwirtschaft zur Auswertung des Briefes des 1. Bezirkssekretärs der Bezirksleitung, 4.1.1962, pp. 1-6.

36. ThHStAW BDVP 20.1/353 BDVP Operativstab, Zur Situation in der Landwirtschaft, 20.1.1962, p. 18.

37. ThHStAW BDVP 20.1/352 BDVP Operativstab, Information 29/62, Vorkommnisse in der Landwirtschaft, 9.3.1962, p. 91. 
38. ThHStAW RdB Erfurt L1153 Rat des Bezirkes Erfurt, Abt. Landwirtschaft, Bericht über die Vorbereitung und Durchführung der Jahresendabrechnung der LPG, besonders in den Nomenklatur-LPG, wirtschaftsschwachen LPG sowie LPG in den Grenz und Höhengemeinden, 5.11.62.

39. ThHStAW RdB Erfurt L52 BDVP Operativstab, Information 61/62, 27.7.1962.

40. ThHStAW RdB Erfurt L52 BDVP Operativstab, Information 4/62: Einige Hinweise zur Beurteilung der Lage in der Landwirtschaft, 5.1.1962.

41. ThHStAW BDVP 20.1/083 BDVP Politabteilung, Protokoll über die Arbeitsberatung der Politabteilung, 9.7.1962, p. 15.

42. ThHStAW RdB Erfurt L1153 Rat des Bezirkes Erfurt, Abt. Landwirtschaft Informatorischer Bericht über den Stand der Jahresendabrechnung in den LPG am 29.1.1962, 31.2.1962.

43. ThHStAW BDVP 20.1/352 BDVP Operativstab, Information 18/62, Vorkommnisse in der Landwirtschaft, p. 75.

44. ThHStAW BDVP 20.1/352 BDVP Operativstab, Information 21/62, Vorkommnisse in der Landwirtschaft, 15.2.1962, p. 80.

45. ThHStAW BDVP 20.1/352 BDVP Operativstab, Information 23/62, Vorkommnisse in der Landwirtschaft, 22.2.1962, p. 86.

46. ThHStAW RdB Erfurt L52, BDVP Stab/Operativstab Information 35/62, 5.4.62; 36/62, 13.4.62; 39/62, 28.4.1962.

47. ThHStAW Bezirksparteiarchiv der SED Erfurt, Bezirksleitung der SED Erfurt BIV/2/4-59 SED Kreisleitung Nordhausen an die BPKK, Einschätzung über den Umfang und die Wirkung der Feindarbeit im Kreisgebiet Nordhausen im III. Quartal 1961, p. 310.

48. ThHStAW Bezirksparteiarchiv der SED Erfurt, Bezirksleitung der SED Erfurt BIV/2/4-59 SED Kreisleitung Eisenach an die BPKK, Bericht über die Feindtätigkeit im Kreis, 30.6.1961, p. 429; SED Kreisleitung Gotha an die BPKK, Feindarbeit im Kreis Gotha, 23.6.1961, p. 449.

49. ThHStAW RdB Erfurt L562 Rat des Kreises Worbis - Abt. Finanzen: Landwirtschaft. Analyse der Entwicklung der LPG hinsichtlich der Erfüllung der Produktions- und Finanzpläne im Jahre 1960, 20.2.1961.

50. ThHStAW BDVP 20/065 BDVP Stab/Operativstab Information 54/60 Vorkommnisse in der Landwirtschaft, 22.9.1960.

51. ThHStAW BDVP 20.1/225 BDVP Abt Schutzpolizei, Protokoll von der Bezirkshelferaktiv-Tagung am 24.4.1961, 26.4.1961, p. 75.

52. E. Strittmatter, Ole Bienkopp, East Berlin, 1971, pp. 260-2.

53. ThHStAW Bezirksparteiarchiv der SED Erfurt, Bezirksleitung der SED Erfurt IV/2/3-335 SED Bezirksleitung Sekretariat Beschluss-Protokoll Nr. 22/60 der Sekretariatssitzung Bericht über der Arbeitsgruppe zur Untersuchung der Ursachen des derzeitigen Standes der Produktivität der Milchkühe (im Kreis Weimar), 4.7.1960, p. 1; ThHStAW Bezirksparteiarchiv der SED Erfurt, Bezirksleitung der SED Erfurt BIV/2/4-58 SED Kreisleitung Eisenach an die BPKK, Bericht über die Feindtätigkeit, 18.4.1961, p. 199. See also J. Gruhle, Ohne Gott und Sonnenschein, Nauendorf, 2000, p. 89.

54. ThHStAW Bezirksparteiarchiv der SED Erfurt, Bezirksleitung der SED Erfurt IV/2/3/414 Bezirkssekretariat der Nationalen Front, Informations- 
bericht V/62: Stand der Vorbereitung des VII. Deutschen Bauernkongresses, 17.2.1962, pp. 14-24.

55. ThHStAW Bezirksparteiarchiv der SED Erfurt, Bezirksleitung der SED Erfurt BIV/2/7-557 Bericht der Arbeitsgruppe die in Arnstadt zur Ernte eingesetzt ist, 10.9.1962, p. 25.

56. ThHStAW BDVP 20.1/364 VPKA Apolda, Aufklärung und Meldewesen an die BDVP, Informationsbericht über die Lage in der Landwirtschaft, 3.10.1962, p. 124.

57. ThHStAW RdB Erfurt L1086 Brief an den Vorsitzenden des RdB Erfurt, 19.9.1962: Beschwerde über die Arbeit mit den Menschen durch den Direktor der MTS Apolda-Heusdorf.

58. ThHStAW Bezirksparteiarchiv der SED Erfurt, Bezirksleitung der SED Erfurt BIV/2/5-44 SED Bezirksleitung Abt. Org./ Kader, Informationsbericht zur Erntesituation in den Kreisen, 5.9.1962, pp. 154-8.

59. ThHStAW Bezirksparteiarchiv der SED Erfurt, Bezirksleitung der SED Erfurt BIV/2/5-44 SED Bezirksleitung Abt. Org./ Kader, Situationsbericht Getreideernte, 9.9.1962, pp. 172-4.

60. ThHStAW BDVP 20.1/352 BDVP Aufklärung und Meldewesen, Information 66/62, p. 158.

61. ThHStAW Bezirksparteiarchiv der SED Erfurt, Bezirksleitung der SED Erfurt BIV/2/5-44 SED Bezirksleitung Abt. Org./Kader, Informationsbericht Nr. 29/62, undated, pp. 281-91.

62. ThHStAW Bezirksparteiarchiv der SED Erfurt, Bezirksleitung der SED Erfurt BIV/2/5-44 SED Bezirksleitung Abt. Org./ Kader, 5. Informationsbericht über die Erntesituation in den Kreisen, 7.9.1962, pp. 163-7.

63. ThHStAW Bezirksparteiarchiv der SED Erfurt, Bezirksleitung der SED Erfurt BIV/2/5-44 SED Bezirksleitung Abt. Parteiorgane, Abt. Org./Kader, Informationsbericht Nr. 29/62, undated, pp. 281-91.

64. ThHStAW Bezirksparteiarchiv der SED Erfurt, Bezirksleitung der SED Erfurt IV/A/2/3-051 Sekretariat der Bezirksleitung, Abt. Org./Kader, Information an das Sekretariat, 1.Anlage, 7.2.1963, p. 155.

65. In Kreis Gotha a total of sixty-five withdrawal notices were recorded in fifteen LPGs: ThHStAW Bezirksparteiarchiv der SED Erfurt, Bezirksleitung der SED Erfurt BIV/2/5-10 SED Bezirksleitung Abt. Org./ Kader, Information über die Tätigkeit der Arbeitsgruppe der Bezirksleitung auf der Grundlage des Sekretariatsbeschluss vom 12.11.1962 im Kreis Gotha, 17.12.1962, pp. 401-6. 
PART II fo

\section{Communicating Reform: The Limits of ECONOMIC TRANSFORMATION}




\section{of 4}

\section{STEPS TOWARDS REFORM}

We still have time and anyway we're not ripe for becoming candidates for party membership! ${ }^{1}$

(Comments by LPG members to SED recruiters in Bezirk Erfurt, July 1963.)

During the 1960s, the impact of the hasty completion of the collectivisation campaign on the consistency with which SED agricultural policies were communicated to the LPGs and implemented on the ground continued to be felt. In 1960, the agricultural workforce in Bezirk Erfurt, as in the rest of the GDR, was marked by a lack of technical qualifications and only very low levels of participation in political parties or indeed mass organisations. From the late 1950s, in conjunction with the collectivisation campaign, the pace of recruitment of farmers by the SED as well as the bloc parties had increased. ${ }^{2}$ At the same time the proportion of the agricultural workforce in training for a technical qualification had also increased. Nonetheless, the rate at which both political recruitment and technical qualification, particularly to an advanced level, could occur by no means matched the speed with which ultimately collectivisation was completed. This defined the context in which LPGs were formed and collective farming was subsequently consolidated and developed in an era of economic reform and technological development in agriculture, as in the rest of the economy.

The use of overt force and mass agitation in rural communities had had some success in ensuring that resistance to SED policies was overcome. Nevertheless, in the process productivity had been severely compromised. Moreover, such an approach was not practically a sustainable basis for the long-term transmission of agricultural policy in any comprehensive or effective manner. The consistency with which district state functionaries were able to see to the implementation of SED agricultural policy continued thus to be hampered by the lack of a clear body of support on the ground within the LPGs. Steps were taken to increase the size and influence of SED party organisations over the LPGs and improve the political reliability and technical and managerial abilities of LPG functionaries. 
The construction of the Wall undeniably played a role in encouraging LPG members to pursue their own interests in conjunction with those of the SED regime, by joining a political party or at the very least pursuing advancement in the collectivised system through participation in agricultural training. Additionally, the transition of the state apparatus for agriculture to a production-oriented administration in 1963 appeared to offer better scope for winning over LPG members to participation in and acceptance of agricultural reform in the pursuit of common material interests. However, in the early 1960s, hostility to SED membership remained strong. Financial and agricultural reform in the LPGs continued therefore to be tempered by the inadequate communication of authority between the district state and party administration and collective farmers. Without the influence of an active and capable body of SED supporters or themselves lacking in a political or technical appreciation for SED agricultural policy, LPG chairmen often lacked either the ability or the desire to implement change in the collective farm, especially where it appeared to be against their own interests or indeed the will of the majority of their constituent collective farmers.

\section{Changing the Context for Communication of Authority}

Both technical education within the parameters of socialist agricultural policy and the expansion of the regime's political network at the grass roots were essential to reconciling farmers with active participation in and development of collective farming. By redefining the terms in which the transmission of authority occurred between the SED regime and farmers, political recruitment and technical qualification were necessary elements in the long-term process of establishing a new stable context in which SED policies could be comprehensively and effectively implemented. A feature of the early 1960s in particular was therefore the concurrent growth of adult qualification levels in agriculture, on the one hand, and, on the other, the expansion of the network of SED party organisations with specific responsibility for the LPGs.

The strength of support for the SED in the countryside was limited in the 1950s by a range of factors. The desire of rural communities for a return to peace following the upheavals of the Second World War, the Soviet occupation and the subsequent de-nazification and land reforms hindered the SED's attempts to find a foothold of support among them. In the face of radical communist policies, the farmer proclaimed himself apolitical and focused on his land and livestock. In its turn, the largely urban SED hierarchy was suspicious and resentful of the rural 
population: villages were religious, conservative and bound by local tradition and long-established social networks which made them impenetrable to an outsider. Some progress had without doubt been made by the second drive for collectivisation, beginning in 1958, in aligning the interests of certain groups of farmers more closely with those of the regime. However, often this alignment was achieved by proxy through the VdgB - the farmers' mutual aid union - and the DBD - the farmers' party established under the auspices of the SED - whose independence at the grass roots made them at best unreliable outposts of loyalty to the party line.

The SED itself struggled in the eyes of most rural communities to be taken seriously as an advocate of farmers' interests, being seen as the party of the urban proletariat more than anything else. Hence, where it did recruit members, it tended to be among those who stood outside the traditional farming circles - the school teacher, the pub landlord, craftsmen, industrial workers who commuted from the villages to the factories as well as the mechanics and drivers who worked in the Machine and Tractor Stations and those workers who had been persuaded to move to the countryside and were organised in either the pioneering - and heavily subsidised - Type III LPGs or the state-owned farms (Volkseigene Güter or VEG).

From the late 1950s onwards important initial steps were taken in recruiting LPG members to the SED and establishing party organisations dedicated to organising and influencing collective farmers. The two exceptional years (1958-60) of exponentially increasing pressure on farmers to collectivise, culminating in the critical last weeks of March 1960, drew lines of loyalty or submission, active opposition and passive resistance towards the regime within rural communities more starkly than before. While forced collectivisation without doubt provoked broad resistance and deepened hatred of the communist regime, it also persuaded some individuals to come off the fence and work together with the SED. In the course of the confrontation, people necessarily grew more accustomed to the idea of collectivisation and took seriously the prospect that once achieved it might not be reversed. Those who saw their future in agriculture undoubtedly considered how best to position themselves within the new system. As a result, alongside the resentment of the SED state, there was also some readiness to compromise with it, which grew as collective farming began to pay off and opportunities for advancement were tied up with party membership. By the same token, as the land was collectivised, more and more members of the LPG began to participate in a process of qualification, which redefined their status and prospects within collectivised farming. 
Nonetheless, the SED lacked a consistently reliable base of active supporters in many LPGs, particularly in the Type I LPGs, for much of the 1960s. Where there were SED members in the LPGs, they did not necessarily have sufficient influence over the running of the collective, being massively outnumbered by non-party members. In January 1961 the SED Bezirksleitung recorded 709 LPGs in the Bezirk without an SED party organisation dedicated to the collective farm (i.e. an SED Betriebsparteiorganisation or SED BPO). ${ }^{3}$ While party organisations existed in all but nineteen villages by June 1961, only 3 per cent of collective farmers in Type I and II LPGs and 8 per cent of farmers in Type IIIs were members of the SED. ${ }^{4}$ By December 1963 there were still 503 LPGs without any SED organisation, despite concerted efforts to recruit SED members among the Bezirk's collective farmers; 423 of these were Type I LPGs.

Recruitment proved especially difficult in the largely Catholic northern and western border districts of Worbis and Heiligenstadt, which continued into the mid-1960s to have the most LPGs without SED party organisations. There were strong disincentives for LPG members to join the SED or even take an active role in so-called LPG-Aktivs, committees of 'progressive' collective farmers which served as pools for potential SED recruits. The potential for social exclusion, particularly where religious loyalty was also a factor, remained in the 1960s a considerable barrier to membership. Speaking at the end of the SED Bezirksparteiaktivtagung in 1964, the first secretary of the SED Bezirksleitung, Alois Bräutigam, despaired at the number of LPGs without a functioning party organisation. He recommended overcoming the reluctance of potential candidates by persuading them all to sign up in alphabetical order so that: 'no one takes the blame for being the first or for being the last. As that's important in villages'. ${ }^{5}$

Very often objections to joining the party focused on the poor example given by existing SED members. Party membership in such small communities was as much a social as a political decision and dislike of those already in the club at a personal level made membership naturally less attractive. Certainly the low reputation of SED members in the village was given as a reason by LPG members for not wishing to join the SED, with arguments such as: 'We're not joining the party, because the comrades are no model for us', 'Put your own ranks in order first', 'Teach your comrades to work like we do first.' ${ }^{\prime}$

In 1962 the KPKK was called in to investigate a particularly severe division between the SED members and other members of an LPG in a village in Kreis Sondershausen. The SED party organisation was at- 
tached to an LPG Type III which had been established there for the past five years and consisted of twelve members, most of whom were LPG members. Given the standards of the time, this was ostensibly a good basis for the SED to influence the day-to-day running of the collective. Unfortunately, the LPG BPO was flawed in a number of aspects. Meetings were only held when the SED Kreisleitung instructor arranged them, and the course of ideological instruction supposed to take place in each of the LPG BPOs annually had not been held once. The party secretary, an SED member since only 1960, had left school after finishing only the 4th grade of primary school and, despite having become a good farmer, had difficulty reading and writing: he was thus more or less unable to run the administrative side of party life and relied heavily on the SED Kreisleitung instructor responsible for this part of the world to do it for him. He was not, however, particularly open to instruction on the ideological issues of the day and knew very little of the party resolutions for which he was supposed to lobby in the LPG. Additionally, he liked his drink and several of his fellow party members were prone to getting drunk in the pub (run, incidentally, by another SED member) and getting into arguments with the other collective farmers.

Non-party members, which included the chairman of the LPG, objected to what the KPKK described as the party secretary's 'selfish private ambitions' (privategoistische Bestrebungen) and relations were marked by continual confrontation. Even in those situations where the party secretary was deemed to have been correct to address deficiencies in the running of the LPG, his actions 'usually took on a hurtful guise so that his criticism gave cause for conflicts from which he drew the wrong conclusions and found himself in opposition to the LPG's economic functionaries'. To make matters worse, the members of the LPG $\mathrm{BPO}$ were all originally factory workers who had themselves brought no land into the collective - a circumstance which gave rise necessarily to conflicts of interest with the established farmers within the LPG. ${ }^{7}$

Even where a party organisation was formed in an LPG in the 1960s, there was no guarantee that its members would be active advocates of SED policies or even take part in the life of the party. In early 1964, an investigation in Kreis Sömmerda found that the agricultural department in the SED Kreisleitung was not particularly efficient in making sure that LPG party organisations were functioning properly. ${ }^{8}$ In the Bezirk as a whole in late 1964 attempts were made to improve the effect of the party organisations on collective farms. Working groups were sent into problem areas by the Kreisleitungen and party activists delegated into LPG party organisations. Severe problems in the LPG BPO 
in the Kreise Apolda and Erfurt-Land were found to be the result of the small proportion of actual LPG members in the party organisations. ${ }^{9}$

The help which party secretaries ought to have been receiving from the Kreisleitung was also found to have been limited owing to a lack of personnel. Instructors found that they were rarely able to do more than give basic administrative help. Instructors for the SED Kreisleitung Sömmerda complained of having to manage the party organisations of up to twelve villages and consequently could achieve little in any one of them..$^{10}$ Party secretaries often tended to do the work of the party on their own with little or no help from other members of the party, with the consequence that in the absence of the party secretary the party organisation ceased to be effective. ${ }^{11}$ Certainly the apathy of a large proportion of SED members in LPG BPO undermined their effectiveness. Party secretaries were encouraged to name and shame nonattendees, and, failing that, to begin a process of party punishments and discussions forcing members to justify their behaviour. Ultimately persistent refusal to attend should have ended in exclusion. An alternative method to such disciplinary proceedings used by party secretaries was simply to report false figures to the Kreisleitung, showing higher attendance than was actually the case. Nevertheless, the attendance levels at party meetings remained a constant source of worry for functionaries in the agriculture departments of the Kreisleitungen because they were regularly found to be lower than in other sectors of the economy. ${ }^{12}$

For the majority of LPG members, the disadvantages of party membership seemed quite clearly to outweigh the benefits, as one disgruntled member of the LPG Olbersleben was reported to have put it to recruiters: 'What influence does the little man have on things, the big men do just what they want anyway?'13 There was also little enthusiasm for the additional work required by participation in party life. Farmers claimed that they had neither the time nor the energy after work to attend party meetings or prepare for them properly by reading up on the political issues of the day, particularly if they had to spend time tending their household plot or livestock. ${ }^{14}$ Nor, indeed, was the prospect of receiving a task assigned by the party particularly welcome. For the ordinary member this could mean taking on extra work in the commissions of the collective farm or at the very least taking an active role in agitating for party policy. For a manager, party membership could result in being selected to advocate SED policy in another (weaker) LPG - again not always an enticing prospect. For example, an attempt to recruit a brigadier in Kreis Apolda failed because he did not want to be delegated into a struggling LPG. Party membership could thus be seen as making for extra duties with few privileges to balance them out. ${ }^{15}$ 


\section{Supplying Loyal Cadres}

It was vital to the SED's long-term goals of transforming agriculture that leading functionaries in the LPG were loyal to the party as well as being efficient managers of production. In the new hierarchy of agricultural production, the LPG chairmen, the board members of the LPG and the mid-level managers of the farms (the brigade leaders and above) were ideally conduits of information and authority, bringing about the most effective implementation of SED agricultural policy by the collective farmers in their local conditions. Politically reliable, technically proficient and managerially capable LPG cadres had thus to be found to communicate the policies of the regime to LPG members and successfully oversee their implementation in practice.

Owing to the decision to complete collectivisation in a very short space of time, by the time full collectivisation was announced, it was clear that insufficient preparation had been made to provide LPGs with functionaries trained in socialist agricultural theory and prepared to organise and run collective farms. Furthermore, there were insufficient numbers of politically suitable cadres willing or able to be delegated into leading posts in new or newly expanded LPGs, either from already established LPGs, other sectors of the economy or indeed the state administration. As a consequence, it was inevitable that the majority of the new LPG cadres were deficient either in political reliability, managerial skill or technical ability.

During the early 1960s the SED made concerted efforts to improve its position in the LPGs. During 1962 SED members involved more broadly in agricultural administration were given targeted training to take up functionary positions in the collective farms. Furthermore, a programme of delegation of functionaries from the district state apparatus, state-owned farms and other stable LPGs, as well as the VdgB and the MTS, into politically or financially unstable collective farms was established. ${ }^{16}$ Overall the number of mid-level functionaries in the LPGs (such as brigade leaders, agronomists and technicians) who were SED members in the Bezirk increased by six times from 1961 to 1962 the result of an influx of trained and party-loyal cadres as well as SED recruitment campaigns in the LPGs. ${ }^{17}$ This was important progress as far as the SED leadership was concerned, in making some collective farms more consistently responsive to new developments in collective farm practices and economic administration. Nevertheless, in 1963 the Bezirk still lacked just fewer than 300 agricultural functionaries with suitable political and technical backgrounds, despite having organised the delegation of 208 cadres since the beginning of $1962 .{ }^{18}$ 
The majority of the LPGs then in existence in 1960 were new and barely functional. Most of them had adopted the statute of the Type I collective farm, opting for the minimum degree of collective ownership and collective farming practice allowed them. The running of many of these new collectives thus did not automatically fall immediately into the hands of those who could be relied on politically. ${ }^{19}$ Leaders were chosen by members of such LPGs for their farming credentials and local connections, not for their subservience to the regime. At the very least, LPG members continued to assert an apolitical stance. As one farmer in an LPG in Kreis Heiligenstadt argued, 'we want practical not political men on the board of our LPG' ${ }^{20}$

Nevertheless, chairmen of LPGs of all types were certainly soon removed from their posts where they had not proved themselves subsequently to be sufficiently constructive in their leadership of the LPG. By the time of the annual members' assemblies, at the start of 1962, the questions of whether or not LPG functionaries wished to remain in their posts and whether or not they were considered suitable - on a political and ideological basis - had become much clearer in the postWall climate. ${ }^{21}$ At the same time, the state's efforts made since 1959 to cover the deficit of both politically reliable and agriculturally trained cadres available for deployment in the LPGs had begun to pay off in a small way. In April 1961 the Bezirksleitung had passed a resolution on the improvement of the development of cadres in agriculture and the qualification of the rural workforce as a whole. This resolution foresaw a range of measures to improve the numbers of LPG members with sufficient political as well as practical abilities to advance collective farming. All production plans produced by LPGs in 1961 were to be accompanied by a qualification plan. Delegates of the Kreisleitungen attached to the various MTS areas were given the central responsibility of ensuring action was taken, not only to persuade farmers of the value of qualifications but also to develop some plans reflecting future cadre requirements. ${ }^{22}$

As a result of such measures the number of farmers exposed to basic agricultural training conducted with a view to application in an LPG increased, providing the basis for the development of a future generation of cadres. Although there were many capable farmers, the long-term transformation of agriculture depended upon the creation of professional managers and technicians of collective production. The expansion of the system of qualification in the early 1960s was a crucial first step in this process, altering the basic context in which farmers perceived agriculture and its future development under the SED regime. ${ }^{23}$ By the late 1960s, as the size of the agricultural workforce declined and 
qualification programmes took effect, the proportion of the total working population in agriculture with a qualification was more than doubled in the Bezirk, from 16.5 per cent to 39.75 per cent. Perhaps still more significantly, the number of LPG members with the technical college certificate increased by 88 per cent. On the basis of these figures it appears that an ever-growing number of farmers were gaining qualifications in order to take up positions as mid- and top-level cadres in the LPGs and were thus now defining their interests and their prospects for promotion in the context of collectivised farming. ${ }^{24}$ As a consequence, chairmen of LPGs who had failed to prove themselves good managers of collective farmers and who had failed to ensure the farm met minimum production targets increasingly could be replaced with more suitable candidates. ${ }^{25}$

Nevertheless, the proportion of LPGs with both a successful and politically reliable chairman remained low. Moreover, while individual party members in positions of authority in the LPGs were certainly necessary if SED agricultural policy was to be seriously proposed for implementation, such individual figures needed, too, the backing of others within the collective farm. Without an effective party organisation to back them, LPG chairmen were slow to develop the financial or agricultural organisation of the collective farm.

\section{New Departures in the Administration of Agriculture}

In the mid-1960s the first steps of a radical transformation of agricultural production were to be taken. The reforms of the New Economic System of Planning and Management (das Neue Ökonomische System der Planung und Leitung or NÖS) and the announcement of plans to progress to industrial-style production in agriculture were intended to bring about a fundamentally new ethos in all types of LPGs, combining both an appeal to farmers' material interests and an insistence on a specifically socialist modernisation of production. Gradual increases in state investment during the mid-1960s brought financial stability to most LPGs and encouraged steps to be taken by collective farmers to increase the scale of production in accordance with SED policies. The processes of economic integration of agriculture into the planned economy and the internal reorganisation of the collective farms which this entailed, however, created fruitful ground for further conflict between the district state apparatus and LPG members.

Type I LPGs began to adopt collective practices more fully, and in some cases accepted mergers with neighbouring collective farms. Lim- 
ited forms of cooperation between LPGs also began to develop. Nonetheless, collective farmers retained opinions on the way in which their LPG, and indeed agriculture as a whole, should develop which diverged considerably from those of the SED leadership. Although the SED state had the potential in individual cases to impose its will upon LPG members and their functionaries, the effective implementation of policy in the long term demanded a less confrontational approach, not least in the interests of increasing production levels.

In 1963, the state administration running agriculture was reconfigured with the creation of Agricultural Councils (Landwirtschaftsräte) at national, Bezirk level (Bezirkslandwirtschaftsrat or BLR) and Kreis level (Kreislandwirtschaftsrat or KLR). The creation of the agricultural councils promised to result in a better standard of leadership by the state in agricultural matters, with a new professional approach to the production process in the LPGs. ${ }^{26}$ The agricultural departments within the Räte der Kreise, which had overseen the collectivisation process, were considered now too bureaucratic and unsuitable for guiding the development of collectivised farming as a fully incorporated sector of the planned economy. The new agricultural councils, in contrast, promised to be more active, professional bodies with primary responsibility for maximising production in the LPGs. Leading collective farmers were to be explicitly included in the decision-making process at district and regional level with the intention of improving the flow of information into the administration from the collective farms themselves. Thus scientists, veterinary surgeons and other agricultural experts were to work alongside collective farmers to come up with the most effective means of raising production using the latest technologies available. ${ }^{27}$

This policy of inclusion was also designed to put aside the 'class' conflicts of the collectivisation campaign in the interests of pursuing the common goal of raising production levels. As the chairman of the LPG Type III Söllnitz put it to his fellow SED members at the SED Bezirksparteiaktivtagung at the end of 1963, economic success depended on including rather than controlling the newer and reluctant members of the LPG. Describing the grounds for the success of his LPG over the previous year, he explained: 'We attempted together in our territory to win over those collective farmers who before [collectivisation] had had the best results. That wasn't easy, since they had been bossed around in the past and their suggestions for improvements to the collective work had been ignored.' With their recategorisation as the 'Class of the Collective Farmers', once-reluctant members of the LPG were now, in theory, to be seen less in terms of their potential for counter-revolution. Rather, due consideration was to be given to their abilities as productive farmers, 
whose opinions on how to improve production in the Type III LPGs should, within reason, be taken into account. ${ }^{28}$

The introduction of this new system of agricultural administration went hand in hand with a number of other proclaimed changes to the conditions in which the LPGs were to function. Plans were announced to begin the development of industrial-scale production in agriculture and were marked by the completion of the transfer and sale of the remaining machinery of the MTS to collective farms. Moreover, new economic reforms for agriculture were announced for 1964 as part of the policies of the New Economic System introduced by Ulbricht in 1963. The aim behind both reforms in agriculture and the creation of the agricultural councils was to shift the emphasis of agricultural administration on to stimulating productivity rather than merely controlling production. The KLRs were to coordinate agricultural plans more realistically with accurate assessments of the productive capacities and profiles of the LPGs in each district. ${ }^{29}$ Equally, with economic reforms, it was expected that LPG members would be encouraged by a system of profit incentives to improve productivity.

At the same time, planning of production would, in theory at least, be organised with greater input from collective farmers rather than foisted upon the LPGs by the district administration. To this end, the number of products for which administrative plan targets would be set was reduced and the dual price system for production over and above the plan was abandoned for arable crops. ${ }^{30}$ As the director of the state produce purchasing organisation at Bezirk level mentioned in December 1963, he expected the introduction of the New Economic System into agriculture to resolve past inconsistencies between the plans of the farms themselves and those of the district and regional administrations. ${ }^{31}$ Following the grim upheavals of the collectivisation campaign and the struggles of the first years of collective farming, there was much optimism among loyal supporters of the SED regime that the NÖS and the agricultural councils would bring both increased production and greater unity within agriculture. ${ }^{32}$

Despite this apparent optimism and the at least rhetorical emphasis on conciliation, neither collective farmers nor all LPG functionaries were quick to embrace attempts to reform their LPG. The increased revenues which accompanied changes to price regulations were welcomed by LPG members. However, there remained considerable suspicion of any new measures which appeared to restrict the incomes of LPG members or diminish or deprive collective farmers of control over their funds, land or livestock in the future. The KLRs' attempts to persuade LPG members to adopt greater degrees of collective use of land, live- 
stock and machinery, and set about the implementation of more refined degrees of financial organisation to stimulate production thus achieved only limited success.

\section{Hostility to Change: the Limits of Reform}

Opposition to outside interference was especially strong in Type I collective farms where, not least owing to the lack of LPG functionaries or members who had joined the SED, mistrust outweighed support for state interference in agriculture. The fear of losing still further control over their land, livestock and machinery was fundamental cause for LPG Type I members to be sceptical of all proposals to restructure the work organisation or reform the financial arrangements of the LPG. For much of the early 1960s the district agricultural councils therefore struggled to ensure the implementation of the basic practices and work organisation of an efficient collective farm in Type I LPGs. It was one thing to establish the LPG as an administrative institution, replete with a hierarchy of command, responsible commissions and the routines of collective democracy, capable of coordinating collective work on arable land; it was another to develop a functioning collective farm which was taking steps to reduce and control the element of private ownership among its members.

Establishing collective livestock herds; organising collective farming of meadowland and of household plots; increasing the level of accumulated capital rather than the level of consumption of profits as income; reducing the significance of contributed land in the distribution of income; introducing internal competition between members; and establishing performance-related pay were all steps which LPG Type I members sought, with greater and lesser degrees of success, to resist. With the implementation of each of these measures, the prospect of the loss of both individual control over private production and the profits arising from it came nearer.

To LPG Type I members, there was not much to recommend merger with a neighbouring LPG Type III either. Merger meant not only having a smaller voice in the running of the farm, it very likely meant coming under the direct influence of an SED party organisation. Most obviously, the transfer of private livestock into collective use amounted to something akin to expropriation as far as some LPG Type I farmers were concerned. The monetary value of the contribution required from Type I farmers joining an LPG Type III was felt to be exaggerated too, while the animals and machinery contributed were often thought to have been 
undervalued. Type I farmers had little confidence either in the greater profitability of collective livestock holdings and indeed expected to suffer financial hardship in the LPG Type III. As can be seen from Figure 4.1, between September 1960 and September 1970 the number of Type I LPGs in existence in the Bezirk dropped at a fairly steady rate, while the number of Type III LPGs remained stable. ${ }^{33}$ In a few cases, mergers, or rather take-overs, undoubtedly occurred with Type III LPGs despite the opposition of the majority of LPG Type I members, although what proportion of mergers occurred on this basis is uncertain. Even where ballots of the LPG Type I members were held, complaints were sometimes heard from collective farmers that they had been forced to vote under duress or misled as to what they were voting for.

Nevertheless on the whole, functionaries at KLRs were aware of the problems created by forcing through mergers of LPGs without sufficient preparation, if not the whole-hearted enthusiasm, of collective farmers. The potential damage to production levels as well as the financial stability of LPGs as a result of the discontent of collective farmers and general disorganisation within the collective farm had been clearly demonstrated in many LPGs in the course of collectivisation. Mergers of Type I LPGs with Type IIIs were necessary to the transformation of agriculture in both the short and long term. As repositories of money, machinery and good stock, as well as farming expertise, Type I LPGs

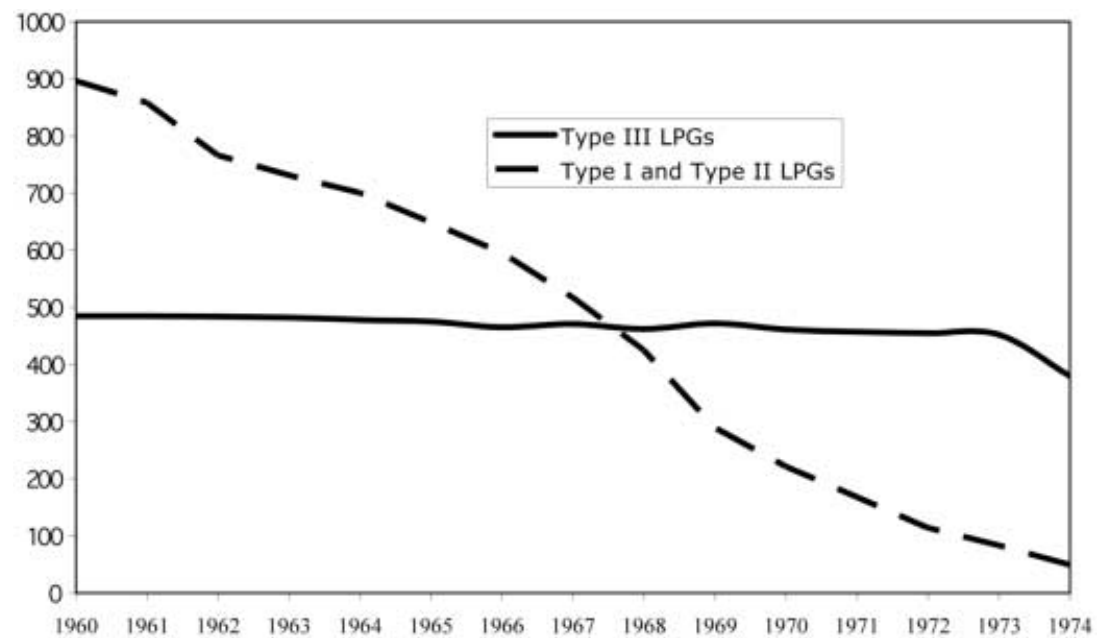

Figure 4.1 Number of Type I and Type II LPGs vs. number of Type III LPGs in Bezirk Erfurt, 1960-74

Source: Staatliche Zentralverwaltung für Statistik, Bezirksstelle Erfurt, Statistische Jahrbücher, Bezirk Erfurt, 1960-1975, Erfurt, 1961-76. 
potentially provided the solution to struggling Type IIIs in need of all these resources.

Pressure from the KLRs on Type I LPGs to merge with neighbouring LPGs, particularly other Type I LPGs, was motivated by practical concern for organising more efficient farming of arable land, enabling larger plantations of single crops. It could also be motivated by the recognition that very small Type I LPGs had very little prospect of sustaining the personnel or the machinery to provide the increases in production necessary to remain profitable in the future. At the start of 1964, nine Type I and II LPGs in Kreis Sömmerda were singled out by the SED Kreisleitung as having no real future as independent economic units. Consequently the provision of financial support from the KLRs was made contingent on these LPGs planning to merge with a neighbouring farm. ${ }^{34}$

The feeling was widespread in rural communities that having once been forced into the LPGs, farmers should at least now be left to get on with improving production without unwanted state interference. In particular, attempts to gauge labour productivity via the introduction of an official documented competition between farmers or the creation of work norms were still widely met with opposition during the early 1960s, particularly in Type I LPGs. The introduction of schemes to increase labour productivity was regarded at best as an unnecessary administrative burden by LPG farmers and functionaries. ${ }^{35}$ At worst, the socialist competition was recognised and rejected as a means of state interference in the running of the LPGs and a lever with which to force increased productivity. The organisation of a competition internal to the LPG, between individual members, appeared too to undermine LPG members' conception of their special identity as farmers, as naturally hard working and dedicated to their land and livestock, putting them rather in the same bracket as mercenary industrial wage labourers. In the words of the chairman of the LPG Type I in Nottleben, Kreis Erfurt-Land: 'Competition is an expression of mistrust. It suggests that farmers are lazy and are only motivated to work by money.'36

Moreover, competition between farmers in the same collective farm was seen as unnecessarily divisive. LPG functionaries already had difficulty in maintaining harmonious relations between the various different members and were unwilling to heighten tension further by adding money to the equation. In August 1962 only ten of the ninety-six LPGs in the district of Gotha had drawn up an internal competition, with LPG chairmen arguing that 'competition causes bad blood' and even that competition 'represents an illegal increase in the work unit' ${ }^{37}$ In April the following year reports on Type I LPGs in the Bezirk as a whole 
reported the commonplace opinion of farmers that: 'Competition brings disharmony in the LPG, especially between the older and the younger collective farmers. Competition does not increase work productivity. ${ }^{\prime 38}$ Reiterating the rhetoric of the labour movement in the Weimar period, an explicit comparison was made between capitalist exploitation and exploitation under state socialism: ‘Today we say competition and before it was called piece work and piece work is murder [Akkord ist Mord]. ${ }^{\prime 39}$

Other administrative methods designed to stimulate productivity in LPGs were also considered with scepticism. In February 1963 information reports on the mood of the population pointed to a number of expressions of opposition to any form of performance-related pay in the collectives on the basis that 'material incentive leads to mutual chicanery between individual farmers; payment according to the final product means discrimination against older farmers since they can't put in the work the young ones can' ${ }^{40}$ Instructors from the KLRs thus met with arguments which dismissed these innovations as unnecessary or even as downright destructive. Comments such as 'competition is just passing fad' or even 'our LPG is too small to run a competition', accompanied more serious complaints as to the divisiveness of competition. ${ }^{41}$

By November 1963 it was noted that socialist competition was still being resisted, with only 228 out of 723 Type I and II LPGs in the Bezirk participating. ${ }^{42}$ By the beginning of 1964, the KLR in Kreis Sömmerda could claim only eight Type I LPGs had developed a good degree of collective work, which included adopting both internal and external competition and some form of performance-related pay. At the other end of the spectrum, six LPGs were found to be still functioning as collectives in name only. The vast majority of Type I and II LPGs had made some - but by no means enough - steps to implement 'good collective practice'. ${ }^{43}$

Having implemented the highest degree of collectivisation of property on the farm, in contrast to the Type I LPGs, the Type IIIs were expected to lead the way in the implementation of the latest elements of economic planning and administration in farming. Their leading functionaries tended more often than in the Type I LPGs to be members of the SED and the size of the party organisation tended to be larger, too, making for a stronger base of support for the latest methods or work organisation proposed by the SED leadership. As a consequence, Type III LPGs were often quicker to develop new incentive-based pay structures and to develop the conditions for specialised and industrial-scale production.

In Bezirk Erfurt as a whole, there was some evidence that Type III LPGs were beginning to prove themselves more capable of producing efficiently. The average income of a member working full-time in an 
LPG Type III rose from 3,360 Marks in 1962 to just over 4,000 Marks in 1963, according to figures from the BLR. ${ }^{44}$ Type III LPGs were able, too, to close the gap in productivity on the average LPG Type I and II in some parts of the Bezirk. According to figures on volume of produce (as measured in grain units) per hectare, production in Type IIIs in Kreis Sömmerda was able to match that of Type I/IIs in livestock and was only slightly lower in crop production in 1963. Nevertheless there remained in 1963 a large number of loss-making Type III LPGs, which were reliant on considerable credits and subsidies from the state, and many more in which working conditions left much to be desired. ${ }^{45}$

There was thus much scepticism about any change which did not immediately promise to improve the conditions under which these LPG members worked or, worse still, which threatened to compromise their incomes. Arguments were made in several LPGs against payment according to work norms and the introduction of performance-related pay, such as: 'What do we need norms for? The main thing is that the work units are correct.' In the LPG Type III Tuttleben in Kreis Gotha, the women of the field brigade were reported to have expressed the opinion: 'Our menfolk had to do piece-work twenty years ago. You lot [i.e. Socialists] are against piece-work, but the performance principle is no different. ${ }^{46}$ Despite improving incomes, it was clear that at the start of 1964, a large proportion of LPG members in the Type IIIs continued to suspect the state via the LPG of seeking to exploit them as workers. ${ }^{47}$

Leading functionaries in the Type III LPGs too resented the burden of implementing management methods which caused disquiet among the members. They objected also to the greater level of responsibility and accountability foisted upon them by the detailed gauges of the LPGs' economic performance now demanded by the KLRs. In 1965, reasonably clement weather over the previous year and a degree of success in the use of machinery collectively had led to a much improved harvest around the Bezirk. As a result, the members' assemblies at the start of the year were marked less than ever by signs of disgruntlement. To the dismay of the BLR, however, LPG chairmen failed to suggest to their members that their improved incomes were a direct consequence of the systems of economic incentive which had so far been introduced. ${ }^{48}$ Even, it was noted, in the most advanced of the Type III LPGs, the internal competition was widely thought to serve no purpose. ${ }^{49}$

Assessing the discussions and statements made at district farmers' conferences held around the Bezirk in March 1965, the BLR found that there was still a considerable shortfall in the extent to which economic reforms had been implemented in the LPGs. ${ }^{50}$ Socialist business economics (sozialistische Betriebswirtschaft) - a collective term used to de- 
scribe the combination of administrative regulations, economic levers and systems of material incentive which LPGs were ideally to employ appeared neither to be fully understood nor accepted by collective farmers and LPG functionaries alike. An information report on the state of the implementation of the NÖS in March 1965 pointed to some sudden progress having been made in winning over LPG cadres in the Bezirk. Following a series of lectures and a propaganda campaign to help LPG chairmen and accountants understand socialist business economics, twice as many Type III LPGs in the Bezirk had reportedly reached an advanced stage in the implementation of various forms of performance-related pay and strict accounting methods. ${ }^{51}$ Nevertheless, proposals to index LPG functionaries' pay directly to the financial results of the LPG still provoked opposition among both brigadiers and LPG chairmen. ${ }^{52}$

If chairmen of the Type III LPGs were not always supportive of new methods by which to run their collective farms, the leaders of Type I LPGs were still slower to insist on the implementation of changes in theirs. The threat to their livelihoods and their independence, which farmers in the LPG Type I perceived to come from the KLR's proposals for the introduction of performance-related pay or greater collectivisation of land or livestock, prevented such issues even coming up for discussion in some Type I LPGs in 1964. In Flarchheim, Kreis ErfurtLand, where the LPG Type I was among the most successful in the district, LPG members were reportedly easily able to resist attempts by the LPG's board to introduce performance-related pay and 'socialist competition'. It was suggested even that the LPG members would seek to vote those board members out of their positions if they continued to advocate such measures. ${ }^{53}$ Elsewhere in 1964 attempts to introduce collective farming of pasture land and develop collective livestock herds continued too to fail in Type I and II LPGs. ${ }^{54}$ Although by May 1965 in the Bezirk as a whole 72 per cent of Type I LPGs had some sort of collective livestock holding alongside privately kept animals, more than half continued to farm their pasture land on an individual basis..$^{55}$

LPGs which resisted any form of change were most numerous in those parts of the Bezirk where Type I LPGs predominated and the SED had failed to establish an effective network of party organisations among either collective farmers, or indeed the rural population in general. This was particularly the case in the hilly northeast of the Bezirk, where the strength of the SED was limited by the resilience of close-knit Catholic communities and where the terrain and the pre-collectivisation pattern of land ownership precluded the rapid development of industrial-scale crop production or intensive livestock holding. In Kreis 
Worbis suggestions that LPGs should begin to specialise production in single crops or in livestock were met with scepticism from farmers. Establishing a coherent arrangement of fields for concentrated production of a single crop was compromised in any case by the patchwork of household plots and dividing walls and hedges which had yet to be removed.

More seriously, farmers refused to countenance such measures on the grounds that they were just the beginning of a plan to expropriate farmers completely. In the neighbouring districts of Mühlhausen and Nordhausen, farmers similarly argued that concentration of production was just going to turn 'farmers' into 'labourers' or that it would make LPGs too dependent on one another to be efficient. ${ }^{56}$ The head of the district ideological commission in the SED Kreisleitung Worbis reported on the ongoing of resistance of farmers to change at the end of 1964. At the root of the problem, he noted, was the fact that LPG chairmen agreed with the SED in principle but when it came to putting policies into practice were either unwilling or unable to see them through. ${ }^{57}$ Where LPG functionaries were themselves in favour of implementing reforms, the unopposed front of resistance presented by LPG members in those collective farms where no or few political ties or loyalties to the SED regime existed meant they found little support within the LPGs. ${ }^{58}$

Progress was made, at least on paper, in many Type I LPGs and Type III LPGs around the Bezirk following the holding of members' assemblies at the start of $1966 .{ }^{59}$ Approximately three-quarters of LPGs, it was reported, had introduced forms of material incentive-making incomes dependent on specific improvements in productivity. ${ }^{60}$ Nevertheless, the number of LPGs that had instituted the full raft of economic reforms which were supposed to drive the NÖS in agriculture remained limited. Type I LPGs in areas such as Kreis Worbis remained particularly resistant to the introduction of performance-related pay, indexed payment of leading cadres, collective farming of household plots and grassland or higher rates of capital accumulation. ${ }^{61}$

\section{Conclusion}

During the course of the 1960s the problem of introducing new working practices into the LPGs was partially solved by a process of qualification, expansion of the party organisations, merger and cooperation between collective farms. Economic reform and the transformation of the conditions of production (however gradual) were nevertheless not warmly received by collective farmers. Functionaries of the KLRs con- 
tinued to face serious difficulties in persuading members and cadres of the LPGs to accept policies which at best they did not understand and at worst to which they maintained a fundamental ideological opposition. The long-term goals of SED agricultural policy ran too often contrary to collective farmers' own conception of their best interests and their own sense of good practice. As a consequence, the implementation of the economic reform required to establish specialised agriculture on an industrial scale and integrate agricultural production into a comprehensive system of economic planning required considerable time and effort. Until loyal and capable cadres occupied the leading positions in most LPGs and reliable political lobbies had been established at the grass roots of farming, it remained problematic for the regime effectively and forcefully to persuade collective farmers - particularly those in the Type I LPGs - that they should and would change their working practices in accordance with SED policy.

The social practices through which the SED leadership sought to exert its authority were by no means straightforward. LPG chairmen clearly had to be responsive to the demands placed upon them by the district agricultural councils to implement reforms and persuade their members to support the state's plans for developing agricultural production. However, they were also bound, if they were to retain the support of their fellow farmers and continue to run a successful farm, to act in their members' interests and respond to their concerns. Attaining good production results and showing themselves not to be hostile to SED agricultural policy - matters on which their future careers depended - entailed balancing and mediating these twin pressures. As long as LPG members sought to assert interests which did not appear to be served by SED agricultural policy, and as long as LPG functionaries lacked the desire or the strength and political support on the ground to overcome divergent opinions, the transformation of agriculture remained a slow process.

By the completion of the administrative collectivisation of farms in Bezirk Erfurt, as in the rest of the GDR in spring 1960, there was a basic deficiency of personnel in the LPGs, but particularly in the Type I LPGs, who would support the introduction of measures designed to reform the financial and agricultural organisation of the collective farms. Steps had been taken since the 1950s to provide sufficient numbers of cadres, loyal to the SED, and trained to run the LPGs in accordance with SED policy. Steps had also been taken to recruit LPG members to the SED in order to create a lobby of support for SED policies within each of the collective farms. However, in the early 1960s the deficiency of personnel remained a problem. 
Despite the construction of the Wall, the stabilisation of the LPGs in the aftermath, and development of a more production-orientated administration for agriculture, the quality and quantity of loyal LPG cadres and LPG members remained insufficient. Collective farmers continued to resist further changes to the organisation of the LPG, not least where these changes appeared to expose the individual farmer to further outside interference. The existence of the LPG had been put beyond doubt; how, and how quickly, it would develop remained a matter of some contention.

\section{Notes}

1. ThHStAW Bezirksparteiarchiv der SED Erfurt, Bezirksleitung der SED Erfurt BIV/2/7-500 SED Bezirksleitung, Büro für Landwirtschaft, Analyse über die Mitgliederbewegung in den ersten 7 Monaten des Jahres 1963 und die Durchführung der Mitgliederversammlungen im Monat Juli,15.8.1963, p. 87.

2. In Kreis Apolda, there was a particularly large contingent of DBD and LDPD members in the LPG: ThHStAW BDVP 20.1/353 6 Bericht zur Situation in der Landwirtschaft, 24.2.1962, p. 43.

3. ThHStAW Bezirksparteiarchiv der SED Erfurt, Bezirksleitung der SED Erfurt IV/2/3-362 Sekretariat der Bezirksleitung, Abt. Org/Kader - Informationsbericht Nr. 4/61, 1.2.1961, p. 100.

4. D. Gabler, Entwicklungsabschnitte der Landwirtschaft in der ehemaligen DDR, Berlin, 1995, p. 125.

5. ThHStAW Bezirksparteiarchiv der SED Erfurt, Bezirksleitung der SED Erfurt IV/A/2/2-042 Protokoll der Bezirksparteiaktivtagung, Büro für Landwirtschaft am 18.12.1964, Beitrag Genosse Bräutigam, 1. Bezirkssekretär, p. 171.

6. ThHStAW Bezirksparteiarchiv der SED Erfurt, Bezirksleitung der SED Erfurt BIV/2/7-500 SED Bezirksleitung Abt. Landwirtschaft, Stand der Mitgliederbewegung, 12.10 .1963 , p. 115. Some examples, from districts across the Bezirk, of the social conflicts caused in rural communities by SED membership: ThHStAW Bezirksparteiarchiv der SED Erfurt, Bezirksleitung der SED Erfurt BIV/2/4-107 KPKK Sondershausen, Bericht über die Untersuchung in der GO der LPG West-Greussen durch die KPKK, 15.8.1962, p. 22; BIV/2/4-288 KPKK Bad Langensalza, Bericht über die Untersuchungen der KPKK in der PO der LPG Hornsömmern, 20.5.1963, p. 155; BIV/2/4-288 KPKK Mühlhausen, Bericht über die Untersuchung der KPKK in der LPG '4. Parteitag' in Ammern, 24.5.1963, p. 162; BIV/2/4-299 KPKK Erfurt-Land, Bericht über die Untersuchungen in der PO/LPG III 'Karl Marx' Grossfahner, 26.10.1964, p. 28.

7. ThHStAW Bezirksparteiarchiv der SED Erfurt, Bezirksleitung der SED Erfurt BIV/2/4-107 KPKK Sondershausen, Bericht über die Untersuchung in der GO der LPG West-Greussen durch die KPKK, 15.8.1962, p. 22. 
8. ThHStAW Bezirksparteiarchiv der SED Erfurt, Kreisleitung der SED Sömmerda IV/A/4.10/077 SED Kreisleitung Sektor Parteiinformation, Einschätzung der MV im Monat Januar, 4.2.1964, p. 83.

9. ThHStAW Bezirksparteiarchiv der SED Erfurt, Bezirksleitung der SED Erfurt IV/A/2/3-099 Sekretariat der Bezirksleitung, Abt. Parteiorgane, Informationsbericht Nr. 22/64, p. 55.

10. ThHStAW Bezirksparteiarchiv der SED Erfurt, Bezirksleitung der SED Erfurt BIV/2/5/363 SED Bezirksleitung Abt. Parteiorgane, Zweite informatorische Einschätzung ... 17.5.1966, p. 11.

11. ThHStAW Bezirksparteiarchiv der SED Erfurt, Bezirksleitung der SED Erfurt IV/A/2/3-179 SED Bezirksleitung Abt. Parteiorgane, Informationsbericht über den Stand der Parteiwahlen ... 22.11.1966, p. 40.

12. ThHStAW Bezirksparteiarchiv der SED Erfurt, Bezirksleitung der SED Erfurt IV/A/2/3-144 BPKK Einschätzung der Parteiverfahren aus dem Jahr 1965 und Erfahrungen aus der Arbeit der PKK im Bezirk Erfurt, 21.1.1965, p. 185.

13. ThHStAW Bezirksparteiarchiv der SED Erfurt, Kreisleitung der SED Sömmerda IV/A/4.10/077 SED Kreisleitung Sektor Parteiinformation, Informationsbericht laut Arbeitsplan, 4.6.1965, p. 204.

14. E.g ThHStAW Bezirksparteiarchiv der SED Erfurt, Bezirksleitung der SED Erfurt BIV/2/5/363 SED Bezirksleitung Abt. Parteiorgane Sektor Operativ Einschätzung zu den Fragen des innerparteilichen Lebens, der Parteierziehung, der politisch-ideologischen und organisatorischen Arbeit der Partei in den GO des Kreises Worbis, 13.10.1965, p. 7.

15. ThHStAW Bezirksparteiarchiv der SED Erfurt, Bezirksleitung derSED Erfurt BIV/2/7-500 SED Bezirksleitung Abt. Landwirtschaft, Analyse über die Mitgliederbewegung in den ersten 7 Monaten des Jahres 1963 und die Durchführung der Mitgliederversammlungen im Monat Juli, 15.8.1963, p. 90.

16. ThHStAW Bezirksparteiarchiv der SED Erfurt, Bezirksleitung der SED Erfurt BIV/2/5-043 SED Bezirksleitung Abt. Parteiorgane, Abt. Org./Kader, Informationsbericht Nr. 8/62, pp. 149-57.

17. ThHStAW Bezirksparteiarchiv der SED Erfurt, Bezirksleitung der SED Erfurt BIV/2/7-495 SED Bezirksleitung Abt. Landwirtschaft, Analyse über den Stand der Entwicklung der PO der LPG, VEG, MTS/RTS ... 24.5.1963, p. 15.

18. ThHStAW Bezirksparteiarchiv der SED Erfurt, Bezirksleitung der SED Erfurt BIV/2/7-602 SED Bezirksleitung Abt. Landwirtschaft, Abt. Org./Kader Kaderpolitische Wertung der Qualifikations der Parteisekretäre in den LPG. 23.3.1963 p.1-4; Abt. Landwirtschaft, Berufsausbildung, 26.7.1965, pp. 26-32; Abt. Landwirtschaft Bericht an Gen. Lüdecke - Stand der Qualifizierung der Werktätigen in der soz. Landwirtschaft, 27.10.1966, pp. 38-39.

19. ThHStAW BDVP 20.1/353 6. Bericht zur Situation in der Landwirtschaft, 24.2.1962, p. 43.

20. ThHStAW Bezirksparteiarchiv der SED Erfurt, Bezirksleitung der SED Erfurt BIV/2/5-043 SED Bezirksleitung Abt. Org/Kader Informationsbericht Nr. 5/62, Neunter Bericht zur Durchsetzung der Direktive des ZK zur Sicherung der Staatsgrenze West, 30.1.1962, p. 80. 
21. ThHStAW Bezirksparteiarchiv der SED Erfurt, Kreisleitung der SED Sömmerda IV/A/4.10/092 Kreislandwirtschaftsrat, Einschätzung der durchgeführten JEV und Analyse der Entwicklung der LPG im Jahre 1963, 19.2.1964, pp. 2-20.

22. ThHStAW Bezirksparteiarchiv der SED Erfurt, Bezirksleitung der SED Erfurt IV/2/3-373 Sekretariat der Bezirksleitung, Beschluss des Büros der Bezirksleitung über die Verbesserung der Kaderentwicklung in der Landwirtschaft und die Qualifizierung der Werktätigen auf dem Lande, 14.4.1961, p. 87-93.

23. The same opinion with regard to farmers in the GDR as a whole is given in SAPMO BArch, DY30/IV 2/7/581 ZK der SED Abt. Landwirtschaft, Bericht über einige Schlussfolgerungen bei der Durchsetzung der Grundsätze zur weiteren Entwicklung des Systems der Berufsausbildung in der DDR auf dem Gebiet der Landwirtschaft, 26.2.1960, p. 21.

24. The proportion of the agricultural workforce with the basic qualification Facharbeiterprüfung rose from 4.5 per cent to 11.5 per cent between 1960 and 1961, while the number of master farmers and those with technical college and university qualifications rose from 2 per cent to 3.5 per cent within Bezirk Erfurt. Statistisches Jahrbuch - Bezirk Erfurt, 1970, Teil I, p. 126.

25. ThHStAW Bezirksparteiarchiv der SED Erfurt, Bezirksleitung der SED Erfurt BIV/2/3/278 SED Kreisleitung Nordhausen an den 1. Bezirkssekretär, 28.2.1963, p. 2.

26. SAPMO BArch DY 30/IV/A 2/2.023/15 Büro Grüneberg, Die besondere Beziehung zwischen genossenschaftlicher und staatlicher Leitung nach dem Produktionsprinzip bei der Verwirklichung des NÖSPL (undated 1964), p. 162.

27. ThHStAW Bezirksparteiarchiv der SED Erfurt, Bezirksleitung der SED Erfurt IV/A/2/3-051 Sekretariat der Bezirksleitung, Protokollauszug von der Bürositzung am 8.2.1963.

28. ThHStAW Bezirksparteiarchiv der SED Erfurt, Bezirksleitung der SED Erfurt IV/A/2/2-38 Protokoll der Bezirksparteiaktivtagung Landwirtschaft am 17.12.1963, Referat Genosse Becker - LPG Söllnitz, p. 68.

29. ThHStAW Bezirksparteiarchiv der SED Erfurt, Bezirksleitung der SED Erfurt IV/A/2/1-009 Protokoll der 5. Bezirksleitungssitzung am 25.4.1963, Referat Genosse Lüdecke, p. 38.

30. SAPMO BArch DY 30 IV/A 2/2.023/15 Büro Gerhard Grüneberg, Die Weiterentwicklung des NÖSPL, 16.6.1964, p. 22.

31. ThHStAW Bezirksparteiarchiv der SED Erfurt, Bezirksleitung der SED Erfurt IV/A/2/2-038 Protokoll der Bezirksparteiaktivtagung Landwirtschaft am 17.12.1963, Beitrag Genosse Riemann, Hauptdirektor der VVEAB, pp. $131-5$.

32. ThHStAW Bezirksparteiarchiv der SED Erfurt, Kreisleitung der SED Sömmerda IV/A/4.10/102 SED Kreisleitung, Information von der am 24.4.1963 stattgefundenen Aussprache im Sekretariat der Nationalen Front, 17.5.1963, p. 3.

33. Staatliche Zentralverwaltung für Statistik, Bezirksstelle Erfurt, Statistische Jahrbücher, Bezirk Erfurt 1960-1975, Erfurt, 1961-76.

34. ThHStAW Bezirksparteiarchiv der SED Erfurt, Kreisleitung der SED Söm- 
merda IV/A/4.10/092 Kreislandwirtschaftsrat Sömmerda - Produktionsleitung, Einschätzung der durchgeführten Jahresendversammlungen und Analyse der Entwicklung der LPG im Jahre 1963. 19.2.1964, pp. 2-20.

35. ThHStAW Bezirksparteiarchiv der SED Erfurt, Bezirksleitung der SED Erfurt BIV/2/5-44 SED Bezirksleitung Abt. Org./Kader, Wie werden in den Leitungssitzungen und Mitgliederversammlungen entsprechend der Beschlüsse der Partei, die wichtigsten Probleme in den Mittelpunkt gestellt? 25.7.1962, pp. 35-48.

36. ThHStAW Bezirksparteiarchiv der SED Erfurt, Bezirksleitung der SED Erfurt BIV/2/5-44 SED Bezirksleitung Abt. Org./Kader, Information 19/62, 30.7.1962, pp. 49-57.

37. ThHStAW Bezirksparteiarchiv der SED Erfurt, Bezirksleitung der SED Erfurt BIV/2/5-44 SED Bezirksleitung Abt. Org./Kader, Kurzinformation 26/62, 13.8.1962, pp. 87-91; Abt. Org./Kader, Sektor Parteiinformation, Faktenmaterial: Wie wird mit dem Ministerratsbeschluss vom 17.9.1962 gearbeitet, pp. 441-9.

38. ThHStAW Bezirksparteiarchiv der SED Erfurt, Bezirksleitung der SED Erfurt IV/B/2/9.01-606 SED Bezirksleitung Ideologische Kommission, Arbeitsgruppe der Ideologischen Kommission, Information und Schlussfolgerungen ... 3.4.1963, p. 17.

39. ThHStAW Bezirksparteiarchiv der SED Erfurt, Bezirksleitung der SED Erfurt IV/B/2/9.01-606 SED Bezirksleitung Ideologische Kommission, Arbeitsgruppe der Ideologischen Kommission, Information und Schlussfolgerungen ... 3.4.1963, p. 20.

40. ThHStAW Bezirksparteiarchiv der SED Erfurt, Bezirksleitung der SED Erfurt BIV/2/5-380 SED Bezirksleitung Abt. Parteiorgane, Abt. Org./Kader an das ZK, Abt. Org./Kader, Informationsbericht Nr. 4/63, 18.2.1963, p. 108.

41. ThHStAW RdB Erfurt L599 Bezirkslandwirtschaftsrat, Analyse über die ökonomische Entwicklung der LPG im Jahre 1963 (undated).

42. ThHStAW Bezirksparteiarchiv der SED Erfurt, Bezirksleitung der SED Erfurt IV/A/2/2-38 Protokoll der Bezirksparteiaktivtagung Landwirtschaft am 17.12.1963, Referat Genosse Thieme, Stellv. Leiter des Büros für Landwirtschaft, p. 22.

43. ThHStAW Bezirksparteiarchiv der SED Erfurt, Bezirksleitung der SED Erfurt - SED Kreisleitung Sömmerda IV/A/4.10/092 Kreislandwirtschaftsrat Sömmerda - Produktionsleitung, Politische Wertung über die Entwicklung der LPG des Kreises Sömmerda im Jahre 1963, 13.4.1964, p. 25.

44. ThHStAW RdB Erfurt L599 Bezirkslandwirtschaftsrat, Analyse über die ökonomische Entwicklung der LPG im Jahre 1963 (undated).

45. ThHStAW Bezirksparteiarchiv der SED Erfurt, Kreisleitung der SED Sömmerda IV/A/4.10/092 Kreislandwirtschaftsrat Sömmerda - Produktionsleitung, Politische Wertung über die Entwicklung der LPG des Kreises Sömmerda im Jahre 1963, 13.4.1964, pp. 21-39.

46. ThHStAW Bezirksparteiarchiv der SED Erfurt, Bezirksleitung der SED Erfurt BIV/2/5-380 SED Bezirksleitung Abt. Parteiorgane, Abt. Landwirtschaft, Informationsbericht Nr.16, 18.6.1963, pp. 344-54.

47. ThHStAW Bezirksparteiarchiv der SED Erfurt, Kreisleitung der SED Sömmerda IV/A/4.10/092 Kreislandwirtschaftsrat Sömmerda - Produktionslei- 
tung, Einschätzung der durchgeführten Jahresendversammlungen und Analyse der Entwicklung der LPG im Jahre 1963, 19.2.1964, pp. 220.

48. ThHStAW RdB Erfurt L1082 Bezirkslandwirtschaftsrat, Fernschreiben an den Vorsitzenden und Produktionsleiter des KLWR, 19.1.1965.

49. ThHStAW RdB Erfurt L1081 Bezirkslandwirtschaftsrat, Berichterstattung an die Bezirksleitung der SED, Abt. Parteiorgane, 18.1.1965.

50. ThHStAW Bezirksparteiarchiv der SED Erfurt, Bezirksleitung der SED Erfurt IV/A/2/3-112 Bezirkslandwirtschaftsrat, Einschätzung der Kreisbauernkonferenzen im Bezirk Erfurt, Schlussfolgerungen, 29.3.1965, p. 152.

51. ThHStAW Bezirksparteiarchiv der SED Erfurt, Bezirksleitung der SED Erfurt IV/A/2/3-112 Bezirkslandwirtschaftsrat - Produktionsleitung, Einschätzung der Kreisbauernkonferenzen im Bezirk Erfurt, 29.3.1965, pp. 141-51.

52. ThHStAW Bezirksparteiarchiv der SED Erfurt, Bezirksleitung der SED Erfurt IV/A/2/3-112 Sekretariat der Bezirksleitung, Einschätzung der Arbeitsgruppe der Bezirksleitung über die Führungstätigkeit des Sekretariats der SED Kreisleitung Nordhausen, pp. 100-19; BIV/2/7-588 SED Bezirksleitung Abt. Landwirtschaft Bericht über die politische Führungstätigkeit zur Herausbildung von Kooperationsbeziehungen, 1965, pp. 476-84.

53. ThHStAW NF 172 Bezirkssekretariat, Vorlage an das Büro für Landwirtschaft bei der Bezirksleitung der SED, 13.6.1964, p. 117.

54. ThHStAW Bezirksparteiarchiv der SED Erfurt, Bezirksleitung der SED Erfurt IV/A/2/3-084 SED Bezirksleitung Abt. Parteiorgane, Informationsbericht, 7.4.1964, p. 16.

55. ThHStAW Bezirksparteiarchiv der SED Erfurt, Bezirksleitung der SED Erfurt BIV/2/5-382 SED Bezirksleitung Abt. Parteiorgane, Informationsbericht Nr. 16/65, 29.5.1965, pp. 181-91.

56. ThHStAW Bezirksparteiarchiv der SED Erfurt, Bezirksleitung der SED Erfurt IV/A/2/3-096 SED Bezirksleitung Abteilung Parteiorgane, Informationsbericht 18/64, 20.8.1964, p. 45.

57. ThHStAW Bezirksparteiarchiv der SED Erfurt, Bezirksleitung der SED Erfurt IV/A/2/2-042 Protokoll der Bezirksparteiaktivtagung, Büro für Landwirtschaft am 18.12.1964, Beitrag Genosse Storost, Leiter der Ideologischen Kommission der SED Kreisleitung Worbis, p. 165.

58. ThHStAW Bezirksparteiarchiv der SED Erfurt, Bezirksleitung der SED Erfurt BIV/2/5/360 SED Bezirksleitung Abt. Parteiorgane, Einschätzung der Kreisparteiaktivtagung Worbis am 2.6.1965, 4.6.1965, p. 1.

59. ThHStAW Bezirksparteiarchiv der SED Erfurt, Bezirksleitung der SED Erfurt BIV/2/7-565 SED Bezirksleitung Abt. Landwirtschaft Einschätzung der bisherigen Ergebnisse der Durchführung der JEV... 12.1.1966, p. 212.

60. ThHStAW Bezirksparteiarchiv der SED Erfurt, Bezirksleitung der SED Erfurt BIV/2/5/384 SED Bezirksleitung Abt. Parteiorgane, Informationsbericht Nr. 6/66, 25.2.1966, p. 14.

61. ThHStAW Bezirksparteiarchiv der SED Erfurt, Bezirksleitung der SED Erfurt IV/A/2/3-159 SED Kreisleitung Worbis, Sekretariat, Bericht über die Führung der polit.-ideologischen Arbeit nach dem 11. Plenum, 3.6.1966, p. 29. 


\section{of 5}

\section{Resistance, Compromise AND 'COOPERATION'}

Cooperation means making sure other LPGs have a higher value of work unit; bringing advantages for some but disadvantages for others; and it means that we'd have to give up what we've achieved to help those who have been left behind. ${ }^{1}$

(Machine Brigade Leader, Wundersleben, Kreis Sömmerda, 1966)

By the mid-1960s, the LPGs were no longer a new or controversial phenomenon. The context in which farming took place in the GDR continued nevertheless to shift, as the SED leadership continued to pursue a radical transformation of the conditions of agricultural production. Levels of recruitment to the SED and levels of more and less advanced degrees of qualification among farmers continued to increase, as the size of the agricultural workforce declined. The economic pressures on members of Type I LPGs to establish collective livestock holdings or agree to merge with Type III LPGs ensured the extent of private farming was being continually scaled back. Moreover, new technology was beginning to raise yields, and in turn improve working conditions and incomes for the agricultural workforce. Nevertheless, growing uncertainty as to their future in a reformed system of socialist agriculture among both LPG farmers and functionaries continued to limit the pace and the extent to which the agricultural councils were in a position to drive the implementation of SED agricultural policy. With no guarantee of financial security there were few LPG members willing to compromise what stability they had thus far achieved.

\section{The Early Development of Cooperation}

Parallel to the debate over the implementation of the NÖS in the LPGs was the issue of establishing the conditions for more cost-intensive mechanised production. By the mid-1960s, after a series of mergers, most LPGs had reached a stable position financially and, responding to the policies of the NÖS, had raised significant levels of accumulated 
capital. This, alongside considerable improvements in the numbers and capacity of tractors, harvesters and other machinery available in the GDR, made mechanised crop production on a larger scale and the beginnings of large-scale intensive livestock production possible. However, it was still not clear what was the most effective means by which collective farmers would be brought to combine their resources.

Solutions to these problems presented themselves in two forms: the development of cooperative relations between two or more LPGs; or the merger of collective farms together to form a so-called Groß $\mathrm{LPG}^{2}$ combining crop and livestock production on a larger scale under a single leadership. There were strong tendencies among some LPG managers to seek to develop the scale of production under their personal control. ${ }^{3}$ In most cases, however, the KLRs were reluctant to endorse mergers between LPGs across more than one village during the early 1960s, for fear this would limit further possibilities for a more effective rationalisation of resources in later years. Moreover, the development of cooperative relations did not preclude but rather provided the basis for possible mergers in the future.

Cooperation between LPGs could occur in a number of different forms and had begun to be developed on a small scale since the early 1960s. LPGs had already started to combine their efforts on construction projects, cooperate on building up stocks of animals between the collectives and form joint land improvement cooperatives. As the 1960s developed, LPGs were encouraged to expand their participation in local cooperative projects - particularly with regard to the use of land and machinery - as increased yields would enable the GDR to become less dependent on importing feed for livestock. To achieve greater yields LPGs had to be encouraged to combine their resources to increase the fertility of the soil and to move on to ever more effective use of the large machinery now available. While few farmers objected in principle to cooperation where there was mutual benefit, there was considerable suspicion of what cooperation might lead to and of how the finances of their LPG would be affected.

Assessing developments in March 1965, the BLR estimated that approximately 15 per cent of the LPGs in the Bezirk were involved in some form of cooperation. The degree of openness to the idea of establishing cooperative relations between LPGs among collective farmers and the leading functionaries of the LPGs varied across the Bezirk. Kreis ErfurtLand and Kreis Weimar had the most cooperating collective farms. In contrast, in Kreis Nordhausen and Kreis Mühlhausen very few LPGs had entered into any form of cooperative relationship. Part of the reason for this difference, even at this early stage in the development of coopera- 
tion, was the different solutions which cooperative relations offered the LPGs in different parts of the country. In the uplands of the Bezirk where the LPGs were small, mainly of Type I and arable land not very easily farmed on a large scale, cooperation was immediately worthwhile, above all for building larger, more efficient livestock sheds, silage and storage facilities. This required LPG members to be willing to invest considerable sums in construction projects which would bind them together with their neighbours for years to come as well as committing them, if they belonged to an LPG Type I, to scale back their private livestock. ${ }^{4}$

Cooperative relations represented a degree of commitment to the long-term transformation of the conditions of ownership for members of Type I LPGs which they considered neither practicable nor desirable. At the SED Bezirksparteiaktivtagung in December 1964 it was reported that among a number of farmers, particularly in the smaller LPGs, cooperative relations with their neighbours were rejected outright. Members of the LPG Type I in Görmar, Kreis Mühlhausen allegedly believed: 'cooperative relations have the purpose of enabling large LPGs to swallow small collective farms and enrich themselves at their expense' ${ }^{5}$ In Kreis Nordhausen members of small LPGs under 100 hectares also doubted the value of cooperation, raising questions such as: 'Aren't we giving up our independence with the creation of cooperative relations? Won't we be done over by stronger LPGs?' 6

In contrast, in the flatlands in the heart of the Bezirk where largescale arable plantations were possible, cooperative institutions were set up mainly to deal with auxiliary processes from crop production such as feed preparation and the transport and drying of crops. Not only was participation in such forms of cooperation not necessarily an overwhelming commitment which entailed compromising the independence of a significant facet of (private) production, it was also of clear and immediate benefit to the LPGs involved. ${ }^{7}$ An analysis of the extent of cooperation in Kreis Erfurt-Land in 1965 noted that all of the LPGs in the district belonged to one of seventeen so-called Cooperative Communities (Kooperationsgemeinschaften or KOGs) of two or more cooperating LPGs. ${ }^{8}$

From the SED's point of view cooperation was an ideal solution to many of the problems undermining agriculture's development since collectivisation. The imbalance in the economic and social development of individual LPGs could begin to be evened out once neighbouring collective farms began to share the burdens of improving production facilities. The influence of politically loyal collective farmers and technically capable cadres was given the opportunity to spread beyond the confines of a single LPG. At the same time, the possibilities increased for 
establishing industrial-scale specialised production above all in joint arable farming between LPGs. Cooperation provided, too, a halfway house to ease the transition for small Type I LPGs on their way to a merger with a larger neighbour. The process of working together brought with it necessarily both greater familiarity and steps towards greater conformity in the financial organisation of the LPGs, potentially making for a smoother merger.

However, these arguments in favour of cooperative relations also provided the basis for much of the opposition from collective farmers, who remained resistant to interference in the internal workings of their collective farm. Cooperation threatened to subordinate LPG members' interests to outside influence, transform their way of life and working practices and potentially rob them of their independence altogether. The progress of cooperation between LPGs depended heavily, therefore, on the collective farmers' perception of their status and future within agriculture in the GDR.

Farming practices had changed since 1960. Investment in construction and machinery for agriculture had brought with it new routines and new expectations for all those involved in the LPGs. In five years of full collectivisation, approximately one in five members of the agricultural workforce had left the profession, while the number of tractors available to the LPGs had doubled and the number of combine harvesters had tripled. The total number of LPGs had been reduced through mergers and a number of Type I LPGs had begun to develop collective livestock holdings. The process of transforming agriculture from small-scale, unspecialised and unconcentrated production methods, over which little direct control could be exerted, into an industrialscale, specialised and concentrated system of production responsive to state demand and more easily subordinated to administrative control had begun with collectivisation. Establishing cooperative relations between LPGs promised to move this process forward. The long-term consequences of developing cooperative relations between LPGs represented, however, a far more dramatic transformation of rural existence in the GDR even than collectivisation.

\section{Grounds for Continuing Hostility to Cooperation}

As a result of the expansion and specialisation of production which went hand in hand with cooperation between neighbouring LPGs, collective farmers expected not only changes to their daily work routine and the location of the workplace but also a change in their status as 
farmers - at the very least a dilution of their rights as theoretical landowners. Both rank-and-file collective farmers and LPG chairmen who had remained suspicious of the impact on them - on their status as farmers and stakeholders in the LPG - of a rapid transformation of agricultural production, thus remained keen to limit the speed with which such measures were implemented. Their reticence was exacerbated by a desire to consolidate and a growing sense of identification and possession of the LPG among its members that rejected the prospect of their LPG losing independent control over its wealth, land and machinery. In 1960 the individual farmer had protested against any incursion on his private ownership of his land or animals or his independence; now, collective farmers acted as one to protect the resources and independence of their LPG.

The First Secretary of the SED Bezirksleitung was at pains to make it clear to leading party members working in agriculture that the precondition for an LPG's participation in cooperation and subsequent merger ought to be mutual consent. Appearing to respond to complaints that Type III LPGs had, with state and party agreement, in fact exploited neighbouring Type Is, he cautioned agricultural functionaries attending the SED Bezirksparteiaktivtagung in December 1965: 'You can't do things, and I say it quite openly, in such a way that the Type III LPGs pillage the Type Is. ${ }^{\prime 9}$

Throughout the Bezirk, LPG Type I members and their chairmen nevertheless remained wary of establishing cooperative relations which threatened to lead to exploitation of their resources and ultimately loss of their independence. In some cases their fears were justified. The BLR clearly intended that the district agricultural councils should concentrate their efforts on establishing cooperative relations between neighbouring Type I LPGs and Type III LPGs where the latter were in clear need of the resources of the former. ${ }^{10}$ During 1965 and 1966 the KLRs thus sought to increase the pressure on the smallest LPGs to develop cooperative relations with their neighbours in order to maximise the scale on which production could be undertaken.

The desire to consolidate what had already been achieved hardened rejection of cooperation even where KLR functionaries argued that independent production was no longer reasonable given the machinery now available. Those LPGs which had begun to achieve a level of profitability were unwilling to jeopardise either this success or their independence, calling upon the authorities of party and state to leave them be for a while. ${ }^{11}$ Members of all LPG types argued that they would rather buy their own machinery with their own money and use it independently even if they weren't able to maximise its effect. ${ }^{12}$ LPG chairmen, 
charged with brokering effective relations with one another, clearly were convinced that their LPGs had much more to lose than others in the long term as a result of cooperation.

In this context it is unsurprising that attempts at the joint deployment of machinery belonging to more than one LPG during the harvest in 1965 were often marred by mutual suspicion. So-called integrated deployments (Komplexeinsätze) of machinery from a number of different LPGs at the same time demanded a clear plan for the order of work and a clear division of authority. Such matters, however, had rarely been finally and definitely agreed upon in August 1965 since LPG chairmen were reluctant to commit themselves to measures which might disadvantage their LPG. The few attempts at the integrated deployment of machinery by groups of LPGs during the harvest in 1965 tended thus to break down. LPG functionaries, it was reported, tended to see to their own concerns before helping their partners in the cooperation. ${ }^{13}$

Attempts to arrange more informal cooperation in the use of machinery between some LPGs in the course of the harvest also tended to break down rather quickly amid confusion and mutual suspicion. Given the importance of exploiting good weather conditions and the potential danger to any crop left too long in the field, the leading functionaries of the individual LPGs were understandably concerned not to lose out to their neighbours in the timely use of machinery. Quite apart from the loss of income, appearing to be hoodwinked by one's neighbours was a sign of weakness which few LPG cadres did not resent, and which few LPG members did not scorn in their leaders.

Without functioning cooperative councils (Kooperationsräte or KORs) to coordinate the resources in men and machines of the constituent LPGs of the cooperative communities, and no formal agreements on how the harvest was to proceed, LPG leaders soon insisted on taking back their own machinery and equipment to harvest independently. ${ }^{14}$ Even in the more advanced districts such as Kreis Erfurt-Land, harvest machine systems were deployed independently by individual LPGs. There were even instances of large Type III LPGs refusing 'socialist aid' to their neighbouring collective farms despite the fact that their machinery was not in use at the time. ${ }^{15}$ LPG Type III farmers resented having to adopt struggling Type I LPGs which appeared to be paying the price now for the ('selfish') refusal to develop their production facilities in the past. Certainly there was no desire to put one's own LPG in financial jeopardy for the sake of another. On occasion chairmen of Type III LPGs were known to refuse proposals from the KLR that they cooperate with farmers from the LPG Type I, at the very least unless they could demonstrate the ability to achieve parity in their yields. ${ }^{16}$ 
In 1965 there was some evidence of successful cooperation between several LPGs based around the small town of Trebra, Kreis Sondershausen. The SED Kreisleitung reported that there had been sufficient prior discussion among leading local cadres - party secretaries as well as LPG chairmen - to enable machinery to be shared between the LPGs. The Kreisleitung's Secretary for Agriculture made clear above all that the key to success had been sufficient preparation of farmers beforehand. In his words: 'LPG farmers prefer not to slip into a finished corset. ${ }^{17}$ It was clear, however, that at this stage LPG farmers of all types along with their leading cadres on the whole were not convinced that they were not going to be stitched up - be it in a corset of either their own making or someone else's. ${ }^{18}$

In 1965 Type I LPGs still outnumbered Type III LPGs in the Bezirk. Of 651 Type I LPGs 122 were less than 100 hectares in size and a further 350 less than 300 hectares in size. ${ }^{19}$ Cooperation was thus put forward as the key to rationalising production while maintaining the rights of the individual farmer, just as collectivisation had been. However, just as they had with collectivisation, many farmers regarded this as yet another restriction on their independence. In contrast to the spring of 1960, however, establishing cooperation by force was not a practicable option. Rather the transmission of SED agricultural policy relied heavily on the willingness and ability of LPG functionaries to explain it and persuade LPG members of its value to them as well as to society at large. It became clear, however, that LPG functionaries remained more often than not unconvinced of the benefits of further change to the structure of agriculture and the establishment of cooperation either to themselves, the LPG members or society in general.

The attainment of a reasonable level of profitability in the LPG, which enabled LPG members to receive satisfactory incomes, had brought a degree of social harmony and stability to collective farms not seen since before the collectivisation campaign. There was thus an understandable desire on the part of the cadres and ordinary members not to rock the boat with further change. This attitude was critically dismissed in the rhetoric of party sources as 'the theory of mediocrity', which derided resistance to further change on such grounds as merely signs of incompetence or cowardice among LPG cadres and ideological backwardness among their members. ${ }^{20}$

After the failure of cooperation during the harvest in 1965, the Bezirksleitung certainly regarded LPG cadres as a weak link in the chain of policy implementation in agriculture, from the development of cooperation through to the use of material incentive and economic levers as part of the New Economic System: 
A whole range of leading cadres in the collectives, chairmen as well as crop and livestock brigadiers are not getting to grips with the current problems of society's development. This is the result of their level of qualification, even though many of them are themselves state qualified farmers or master farmers ... In most cases the functionaries appear to be the progressive party in the collective. But already in the boards of the collective farms these leading cadres often do not find sufficient support in order to realise the tasks in the collectives individually ...

Worse still, many LPG cadres clearly had no desire to continue in a position where they were under constant pressure to push through policies which the majority of their fellow farmers rejected. The report continued:

In all the districts in which new elections are being held there are problems with filling posts as chairmen and board members. They refuse to be candidates using in part paper-thin arguments. They claim not to understand the integrated deployment of machinery and cite among other things internal difficulties in the collectives, health reasons, age, unreasonable state demands for grain delivery, poor support from the board, differences within the LPGs. The real causes lie however not in these arguments but are rather to be found in the fact that these chairmen shy away from confrontations with LPG members over the implementation of the decisions of the party and the government. ${ }^{21}$

Given the degree to which LPGs of all types, but particularly Type I, were failing to take the steps to develop with the speed the SED leadership desired, doubts were raised as to the competence or indeed the political reliability of the leading cadres of LPGs. It had already been made clear that LPG chairmen who proved flagrantly to be unable or unwilling to establish a functioning collective farm were liable to be labelled opponents of progress and removed from their posts. ${ }^{22}$ However, immediate wholesale changes to those running LPGs which were not rapidly implementing SED policies were neither possible nor worthwhile. Not only was there a lack of suitably qualified, suitably skilled and suitably reliable replacements, but transforming agriculture while retaining some stability in collective farms and winning LPG members' support for the transformation was recognised to be necessarily a gradual process.

In the face of ongoing hostility to cooperation from LPG members and LPG functionaries, administrative attempts were made to move the situation forward in the Bezirk. To ensure members of smaller LPGs supported cooperation or merger, the head of the BLR made it clear at the end of 1965 that, in future, access to new machinery would be predicated on the development of effective cooperative relations. Type I 
LPGs with less than 100 hectares would not be able to purchase machinery until they could prove that it would be used to the maximum of its capacity. Similarly, no credit would be given to enable the construction of larger sheds for livestock unless Type I LPGs were participating in a cooperative enterprise. ${ }^{23}$ Reporting in March 1966, the agriculture department in the SED Bezirksleitung suggested that in most cases it was relatively clear to the LPG functionaries with whom and how cooperative relations could be set up. The essential problem was that these leading cadres either claimed to find it impossible to gain the support of members or had simply refused to confront them on this issue. ${ }^{24}$

Particularly in the Type I LPGs in the Bezirk, there was a willingness to resist cooperation in practice and a continuing suspicion of the regime's motives in insisting upon it. In Kreis Worbis, the SED Kreisleitung reported a range of arguments widely raised against those state and party officials advocating cooperation between LPGs in the district: 'We don't need cooperative relations for machinery; we'll carry out our own work alone, we've got enough tractors and horses ... you want to take away from us our right to use the machinery we bought ourselves.' It was clear too that there was a fundamental hostility to the state's repeated attempts to interfere in the running of the collective farms. LPG Type I members in Kreis Worbis responded to SED Kreisleitung functionaries with comments such as: 'Why don't you leave the LPGs in peace? You've always got something new.' ${ }^{25}$

During 1966 LPG chairmen were put under increased pressure by the KLR to sign their LPGs up to participation in a KOG and commit their machinery to cooperate in crop production during that year's harvest, regardless of the attitudes of the collective farmers themselves. ${ }^{26}$ By August 1966, at least on paper, the development of cooperation appeared to have advanced with all but twenty of the Bezirk's 1062 LPGs apparently signed up to participation in a cooperative community (KOG) with other LPGs. The KLRs' administrative success in this regard, however, again failed to match up with the actual practice of the LPGs during the harvest. Rather as during the collectivisation, it was one thing to gain agreement in theory, it was quite another to see to a policy's implementation in practice. In this respect, LPG chairmen remained as clearly beholden to their members' opinions when it came to carrying out the harvest, as they were, at least outwardly, to conforming to the demands of the KLRs.

Thus, in much of the Bezirk harvest machinery was reported to have been used with only the minimum lip service paid to the notion of cooperation between LPGs. Until strict agreements had been reached between LPG chairmen and ratified in a vote of the respective members' 
assemblies of the LPGs, it was argued that cooperative use of machinery could only occur under the terms of 'socialist aid' and hence not in a coordinated deployment, as the KLR might have wished..$^{27}$ Even where tentative agreements had been made, LPG Type I chairmen tended, as they had the previous year, to withdraw their machinery and return to working independently after only a matter of days. ${ }^{28}$ In Kreis Worbis the development of cooperation had been outwardly successful, with the inclusion of all the LPGs in the district in one or another KOG. In practice, individual LPGs resisted using their machinery in cooperation with one another, reaching agreements only on temporary exchanges of machinery. ${ }^{29}$

At this stage it was clear that few LPG chairmen were either willing or able to begin more than superficial cooperation during the harvest. Collective farmers, if not LPG chairmen themselves, had by this stage not been sufficiently persuaded of the value to them of cooperating with their neighbours in crop production. Until they could be persuaded, the KLRs were forced to accept that cooperative relations would not develop with any degree of consistency or comprehensiveness. The balance of interests which defined the organisation of agriculture remained heavily influenced by farmers' concern to protect their rights of ownership and the independence of local decision making, against the SED leadership's project of industrialising production and rationalising administrative control over LPGs and rural communities at large.

\section{Competing Interests and the Obstacles to Persuasion}

During 1967 and 1968 the SED leadership in the Bezirk sought to make more rapid strides towards the development of advanced cooperative relations between LPGs in crop production and the implementation of a set of financial controls in the LPGs which would make them more responsive to incentive-based economic planning. The extent to which this was achieved continued, however, to be hampered by the insufficient reliability of LPG functionaries and the inadequacy of the network of regime supporters at the grass roots - primarily in the SED party organisations but also in the DBD.

In the mid-1960s there were simply not enough LPG leaders who could be relied upon to advocate cooperation to their members and to cooperate successfully with their neighbours, being themselves neither convinced of the logic of such measures agriculturally nor indeed supportive of any steps which appeared to compromise their own personal authority. How far LPG chairmen's attitudes towards cooperation con- 
formed to those of the SED leadership depended in large part on how beneficial to them and to their LPG it might prove to be. It was also dependent on how strongly they were influenced as well as supported by the SED party organisation attached to their collective farm. As far as cooperation was concerned, however, LPG chairmen and even SED party organisations in the LPG, let alone the rank-and-file collective farmers, found that they had good reason to be sceptical of the benefit to them of the policy in practice, if not in theory. In the rhetoric of the administration's documents, 'Betriebsegoismus' ('Enterprise Egotism') was seen to be at the root of the failure of cooperation. ${ }^{30}$

With regard to the LPG, the phrase 'Betriebsegoismus' covered a multitude of apparent sins against the spirit if not always the letter of SED agricultural policy. Essentially it was used to describe any behaviour or act undertaken by LPG chairmen which was considered to be purely in the interests of the success of their own collective farm and consequently to the cost of others. Although it was clearly used as a label to criticise the behaviour of LPG functionaries who were not wholehearted in their support for cooperation on the terms proposed to them, it did identify a real obstacle to successful conduct of cooperative relations between LPGs. Regardless of political loyalties, collective farmers were openly hostile to any measures which threatened to compromise their incomes or their independence and were capable of bringing pressure to bear on their leading functionaries to prevent their implementation. How well these cadres worked together was crucial to the success of cooperation. However, there were considerable obstacles to a harmonious relationship between LPG chairmen. Not only did they have their own individual concerns not to be seen to be outdone, the scorn they could face from their constituent collective farmers if thought to have failed to act in their best interests could make their position untenable.

Within the LPG and the KOG Walschleben, Kreis Erfurt-Land, clashes of personalities became a serious problem between 1965 and 1967. At one point members of the LPG Type III Gebesee were reportedly openly opposed to continuing with cooperative relations with their neighbours, accusing their chairman of being so subservient that he was little more than 'the coach driver' of the chairman of the LPG Type III Walschleben. ${ }^{31}$ During a discussion in Heringen, Kreis Nordhausen over the future of cooperation between LPGs in the area in April 1967, the chairman of the LPG Type III in Urbach pointed out how difficult it was for chairmen of the Type I LPGs to persuade their members:

Our colleagues in the Type I and II LPGs, the chairmen and board members who are concerned to participate [in the KOG] are still subject to serious attacks. The development, which would have been reckoned good 
thus far, reached its high point with an almost catastrophic collapse. The chairman of the LPG Type II was heavily criticised by his members who accused him of wanting to throw everything away; they had given him the title 'the red general' and said that he was selling the LPG out ...

Under such pressures, cooperative relations tended to break down. Thus it was that a working group from the Bezirksleitung monitoring the harvest in 1967 in Kreis Apolda found a number of LPGs refusing to allow their harvesters to be used in combination with those of other LPGs. One LPG chairman reportedly defended his actions on the basis that he could not afford not to look after his own farm's interests first: 'Last year we were conned by the integrated deployment of machinery. We gave up our harvesters when the weather was good and then all we received was wet grain. ${ }^{33}$

Part of the opposition to cooperative relations even from among those who were ordinarily supportive of the regime's goals for industrialising and modernising agricultural production was the result of divergent opinions on the means to achieve these goals. There had long been strong tendencies among LPG functionaries to seek to create large self-contained mixed arable and livestock farms. These would operate on a scale sufficient to use the latest technologies and scientific theories to increase productivity, while overseeing the balanced development of both strands of production. ${ }^{34}$ The essential argument in favour of Groß LPGs was the importance of maintaining the traditional direct relationship between feed production, livestock and organic fertiliser under one administration. Adherence to this principle did not, however, tally with the principles of a progressive industrialising agricultural policy, which sought to dispense with such outdated approaches to farming.

From a production perspective, maintaining mixed farms on this scale threatened to put unnecessary limits on the extent of specialisation of production possible. Agricultural production had to be responsive to the demands of the economy as a whole and had to develop accordingly. As part of a wider complex economic system, the potential for increasing production through intensive specialisation where possible took precedence over maintaining what appeared to be simplistic and outdated notions of the interdependence of crop and livestock farming. Additionally, the Groß LPGs gave too much power to the individual chairmen who ran these giants. They also created a degree of bureaucracy and administrative complexity internal to the LPG which not only made them difficult to run efficiently but limited the extent to which their practices could be scrutinised by the state.

In their size, Groß LPGs bore the stigma of the Soviet Kolkhoz, in which farmers - according to popular perceptions born in part, no 
doubt, out of Nazi propaganda as well as the actual experiences of German POWs - were deprived of an individual status and condemned ultimately to work as farm labourers ruled by office-bound apparatchiks. However, as an approach to developing autarkic production in the GDR, it appeared to offer a happy compromise for some LPG functionaries between modern practices and scale, on the one hand, and traditional farm organisation and local identity, on the other. It also made redundant any complex cooperative agreements between neighbouring LPGs and appeared to avoid the traps of suspicion and conflict that went with cooperation. Moreover, as more LPG Type I members were persuaded to relieve themselves of the burdens of private livestock production by joining the Type III LPGs, merger rather than cooperation appeared to be a more successful approach to reaching an expanded yet sustainable scale of agriculture.

During the late 1960s, economic pressures and an ageing workforce were beginning to have an effect on the ability of the Type I LPGs to maintain their independence. A stagnation in the level of production had already begun to take place since 1967, with percentage increases in production in a number of upland districts, where Type I LPGs predominated, growing at a slower rate than the Bezirk average. The extreme age of many members of the Type I and II LPGs, whose children could not be kept in the LPGs and who were unwilling or unable to continue to farm, naturally limited the quantity of produce that they made available to the state. In the past the burden of work on individual members had been kept down by transferring animals from private holdings to collective holdings in sheds which had been extended for the purpose, as it became necessary. However, without extensive investment in modern livestock sheds, the potential options for accommodating animals with the workforce and the buildings available were becoming increasingly limited in the Type Is. Given bottlenecks in the supply of materials and a general lack of funds to invest in a suitably extensive programme of construction in the upland districts of the Bezirk, those members of Type I LPGs who were not seeking to retire found themselves forced to petition to join the Type III LPGs in order to sustain an adequate income.

Type III LPGs did not necessarily respond to the plight of their neighbours with great sympathy. Previous conflicts and rivalries between neighbouring LPGs of different types, as well as the high incomes of many Type I farmers over previous years, tempered the willingness on the part of Type III farmers to help. At the very least this manifested itself in tough conditions for merger set by Type III LPGs, who were often only willing to take over whole LPGs rather than accepting merely those 
farmers who were unable to keep their own private livestock any longer. Mergers inevitably took place without the consent of all members of the Type I LPGs. Disgruntlement among former LPG Type I farmers following merger into an LPG Type III could indeed be serious enough to make clear to the Ministry for State Security the need for further recruitment of informants to give regular reports on the situation. ${ }^{35}$

The compromise position of allowing some farmers to maintain extensive private livestock despite having become members of the LPG Type III was one method of easing the immediate burden of merger on both parties. However, in Bezirk Erfurt in 1968 the practice appeared to be largely limited to LPGs in Kreis Eisenach, with only odd examples thus far in other districts. ${ }^{36}$ In some Type Is the resolve to resist merger among the members hardened and farmers echoed their comments made during the original collectivisation campaign, insisting that 'as long as it's still possible, we continue as we are' ${ }^{37}$ In 1968 for more Type I LPGs than ever before, merger with LPG Type IIIs was, however, unavoidable. Of the 517 LPG Type Is in existence in Bezirk Erfurt in September 1967, only 289 existed in 1969.

The expansion of the proportion of agricultural land that was farmed under the statute of LPG Type III and the reduction of the extent of private livestock farming to the benefit of collective livestock holdings certainly aided the evolution of the SED leadership's general policy of transformation of agriculture and rural society. The incorporation of more pasture and arable land, machinery and buildings and, above all, financial resources certainly enabled the development of production on a grander scale. More importantly, the incorporation of Type I LPGs into Type III LPGs promised to enable the communication of agricultural policy to collective farmers in a more comprehensive and consistent manner.

The pockets of hostility to change which Type I LPGs so clearly represented during the earlier 1960s were increasingly subsumed in the Type III LPGs. Recalcitrant chairmen and board members of Type I LPGs were no longer in a position to delay changes to the structure or practices of farming in their local area and the members in general who were hostile to agricultural transformation could no longer necessarily expect to win a majority of votes during members' assemblies. Nevertheless, the expansion in size of Type III LPGs did not necessarily make them entirely pliant to the demands of the KLRs for agricultural development. Indeed, in some respects the growth in power of single LPGs as economic units enabled LPG leaders to seek to run agriculture more on their own terms rather than those proposed by the district party and state administration. 
Some chairmen of large Type III LPGs on the plains of Bezirk Erfurt began to assert themselves, maintaining that cooperation was not necessary for their farms. By 1967 mergers between LPGs (whether preceded by cooperation or not) had enabled LPG chairmen to expand the size of single collective farms sufficiently to claim to have no need of developing formal cooperative relations with their neighbours. At their current size, chairmen pointed out, the LPGs were easily capable of developing field sizes sufficient to use the machinery currently available to its full capacity. Members of large LPGs in Bad Langensalza thus maintained that they already had developed the conditions for industrial-scale farming and had no need of cooperation in order to use their machines efficiently. The size of their fields, they claimed, matched the specifications set by the VIII German Farmers' Congress for the use of the latest machine systems. ${ }^{38}$ Similarly, in Kreis Erfurt-Land resistance to cooperation was based on the LPG leaders' confidence in being able to cope without it, with arguments such as: 'We have a high level of production, we deliver a lot to the state, why should we introduce something new?' Even when the value of cooperation was conceded, there was seen to be no reason why it should be permanent cooperation. ${ }^{39}$

Such attitudes, however, showed up a serious deficit among leading cadres, even in Type III LPGs, of obedience to or understanding of the 'correct' path of future development in agriculture in the GDR. As often as not, LPG chairmen appeared more willing to ensure that their LPG increased production than back SED agricultural policy. As conduits of the SED leadership's authority and participants in the apparatus of social and economic management of the countryside, they were by no means consistently effective or obedient.

\section{The Ideological Deficit in the LPG}

The balance in authority between LPG chairmen and the LPG members who sat on the directing board of the collective farm, on the one hand, and the SED party secretary and the party organisation, on the other, was crucial to the way in which proposals for significant change in the organisation and structure of LPGs were communicated to and received among the collective farmers. Ideally, there was considerable overlap between the members of the SED party organisation and the leading LPG members who made up the LPG board. Equally, the chairman of the LPG was ideally also a member of the SED, ensuring that the party organisation took a leading role in shaping the development of the collective farm in line with the latest proposals of the SED leadership. 
In practice, SED party organisations in the LPGs varied considerably in size and activity, and the degree of influence which they sought or were able to exert over the LPG's leaders - or indeed the collective farmers in general - was often minimal. LPG chairmen, regardless of their party affiliation, were not consistent in their support for the concerns of the party secretary or the party organisation where they appeared to differ from his conception of the interests of the LPG. Moreover, the board members of the LPG (the majority of whom were largely without a party affiliation) could represent a more dominant, influential body of opinion among the members than any party organisation.

SED Party organisations in the farms (Betriebsparteiorganisationen or BPOs) appeared at times to be either ineffective or indeed themselves not united in support of SED agricultural policies. The attitudes of SED members on the ground in the individual LPGs also certainly did not always conform to those expected of them by the SED Kreisleitung. Where Type III LPGs were concerned, the unreliability of the SED members and the SED party organisation were particularly apparent on the issue of cooperation. ${ }^{40}$ SED BPOs, where they existed and where they supported cooperation, were unable to have much of an impact on LPG chairmen let alone LPG boards, mid-level managers (i.e. work brigade leaders and technical advisers) and collective farmers in general. ${ }^{41}$ In Kreis Sömmerda throughout 1967 the SED Kreisleitung received reports of discord - even where BPOs were considered to have some influence - between members of the board, the chairmen and the SED party leadership on essential questions of cooperation. ${ }^{42}$

Even in Type III LPGs with relatively large party organisations, issues such as cooperation between LPGs still provoked enough opposition to the party line as to render party members powerless in the face of such opposition. In the LPG Type III in Beichlingen, for example, the Kreisleitung Sömmerda claimed in 1968 that: 'the influence of the opposing forces goes so far that the class conscious forces of the party organisation are being pushed onto the defensive'.$^{43}$ A general overview of the district farmers' conferences throughout the GDR in 1968 revealed continuing antipathy towards cooperative relations.

Just as had been the case after collectivisation - when individual farmers adopted the trappings but not the actual practices of collective farming - so too now were LPGs found to be cooperating in name alone. KOGs were found to have formed to the extent that a cooperative council had been organised but beyond this no practical action was actually being taken to alter the structure of the farms or the organisation of work. Even where chairmen had gone so far as seemingly to cooperate fully in the farming of the arable land between the constituent LPGs, 
the reality was not always very far removed from the practice pre-cooperation. The brigades and crops continued to be organised primarily in accordance with the territorial boundaries of the constituent LPGs. ${ }^{44} \mathrm{In}$ Kreis Sömmerda in July 1968 attempts to introduce the integrated deployment of harvesters were reportedly rejected by LPG functionaries despite the insistence of the SED BPOs. ${ }^{45}$ The effectiveness of the BPOs of a number of Type III LPGs was thus increasingly called into question, particularly as regarded making the case for cooperation. ${ }^{46}$

The failure of the SED BPOs to influence LPG cadres with regard to the implementation of economic reforms within the LPGs was also apparent. This was most obvious in the Type I LPGs, where SED party organisations - if they existed at all - tended to be small and where the LPG chairmen and certainly the LPG board members were often not party members. It was also the case, however, even in a number of Type III LPGs, that leading cadres were basically unresponsive to the SED party organisation's proposals to develop their LPGs in accordance with the principles of sozialistische Betriebswirtschaft. In meetings of the SED party organisations in October 1967 in Kreis Sömmerda, among the reasons cited for their continuing failure to influence the development of their collective farms was the repeated failure of management cadres to speak politically to the work collectives. ${ }^{47}$ LPG cadres were reported to be continuing to oppose economic reform on the basis that it caused disquiet among members of the LPGs and that the LPGs lacked sufficient numbers of cadres to implement it in any case. ${ }^{48}$

\section{The DBD and Voices of Conservatism}

While the numbers of SED members in leading positions in the LPGs had increased by 1968, the KLRs and the SED Kreisleitungen were still reliant on a considerable proportion of functionaries in the LPGs who had not joined a party or who were members of one or other of the bloc parties (primarily the DBD, the Democratic Farmers' Party of Germany) to advocate their agricultural policy. The DBD leadership's role in the collectivisation campaign had long since signalled an end to the DBD's potential to be a political refuge for those with opinions about agriculture in the GDR that diverged radically from those of the SED. However, the DBD continued to claim a membership among newly collectivised farmers, particularly among members of the Type I LPGs where the SED struggled to find any support following collectivisation.

In 1963 the DBD leadership formally adopted the party programme of the SED as its own, making thereby a definite statement of its subor- 
dinate position in agriculture as in other matters to the SED. After 1963 the DBD hierarchy could thus, on the whole, be relied upon to speak publicly in favour of SED policy and maintain party discipline within its ranks. However, DBD members did not automatically become nearly as accepting of the SED's claim to know best how to develop agriculture. An assessment by the SED Central Committee of the ideological situation in the DBD prior to the elections to the Volkskammer (National Parliament) in 1963 noted that there were signs of dissent among DBD members throughout the country at their party leadership's apparent capitulation. Wherever local groups of the DBD had a large membership, resistance to accepting the SED's leading role in agriculture remained strong. Arguments were reported to be prevalent among DBD members such as: 'the SED should decide things among workers and in industry and the DBD should do so in the countryside'. DBD members who were members of Type I LPGs certainly did not appear as a result of the DBD's new status to have developed any less suspicion for aspects of SED policy which appeared to put them at a financial disadvantage. Many DBD members clearly continued to have little regard for SED agricultural policy or indeed for SED functionaries' ability to decide agricultural matters correctly. ${ }^{49}$ Such attitudes persisted into the late 1960s..$^{50}$

Despite the proclaimed loyalty of the DBD to the SED agenda, at the grass roots members of the DBD often claimed greater technical expertise and were willing to criticise any proposals that they considered impractical. ${ }^{51}$ Some DBD functionaries recast the old debate of received farming wisdom and accepted practice versus the SED's progressive agricultural policy as practical conservatism in the LPG versus change for change's sake. With the LPG Type III Neuholland held up as a national model for the introduction of socialist business economics in LPGs, many mid-level cadres in the LPGs who had joined the DBD explained their reluctance to introduce similar measures themselves by emphasising the differences between this model LPG and their own situation. 'We lack the qualified staff to do the office work,' they protested, 'We don't have the sort of support from academics like they do in Neuholland.' Alternatively they pointed out, with the sort of (justified) self-satisfaction which infuriated the district functionaries of the SED, 'We fulfil our plans even without Neuholland's methods. ${ }^{52}$ The so-called 'green comrades' (Grüne Genossen) of the DBD were thus regularly criticised for their lack of support for the evolution of socialist agricultural policy, for the sake of their own LPG's interests.

In March 1968 speakers at the SED Bezirkparteiaktivtagung reviewed the causes of the failure of LPG cadres to adopt the economic reforms 
required of them. Mid- and top-level cadres had, according to the SED Bezirkleitung's agricultural secretary, failed to grasp the 'systematic character' of the NÖS. The financial organisation of LPGs had to be transformed in order for agriculture to be integrated efficiently into the wider reformed economy. Agriculture was to be seen as a part of a wider system that created flexible responsive links between aspects of agricultural production and other interrelated sectors of the economy. It had therefore to develop appropriate corresponding forms of financial organisation as defined by socialist business economics. The fact that economic reform had not been fully achieved appeared therefore to be in large part down to the failure of LPG cadres to see the value or necessity of this project of economic integration.

It was apparent that there was a deficit in the extent to which LPG chairmen sought actively to implement change, responding in part to the concerns of their members. In the Bezirk as a whole only seventyfive LPGs had actually introduced the reforms comprehensively. ${ }^{53}$ In Kreis Weimar six LPG chairmen were named and shamed at the District Farmers' Conference in April 1968 for having done nothing to implement socialist business economics. Rather more had failed to implement one or other of the essential reforms required of them. The continuing failure of these cadres to take action in their LPGs smacked therefore either of a lack of ability or a lack of reliability. Either, it was suggested, they did not understand the issues involved or they were afraid of confronting old traditions and ideas about farming. ${ }^{54}$

\section{Uncertainty and the Limits of Transformation}

At the heart of the reticence of farmers and functionaries within LPGs of all types to accept cooperation or the economic reforms was a lack of confidence in the positive effect of further change. There was no doubt that the development of cooperation raised numerous fundamental existential questions. Many women farmers feared that they would not be given work in their own village once cooperation was underway. The loss of flexible working hours and proximity to the household and children represented a considerable upheaval in the lifestyles of women in rural communities, which were not necessarily thought to be positive. ${ }^{55}$ Men also had their doubts about going to work away from their local area as a result of cooperation. Nor were they particularly confident of having to work alongside strangers. A number of tractor drivers were found to doubt whether the other drivers they worked with would be as diligent as them. More generally, the fear of loss of earnings or finan- 
cial insolvency as a result of having to cooperate was paramount. ${ }^{56}$ In July 1968 mid-level cadres in the LPGs were reported, too, to be in fear of losing their positions as a result of cooperation. Ordinary farmers, among them SED members, predicted it would be their 'doom' ${ }^{57}$

The arguments against socialist business economics reportedly given by mid-and top-level cadres in LPGs tended to see reforms as too much extra work and hardly worth introducing as a passing fad. ${ }^{58}$ The differing genesis of LPGs, in the course of the ten to fifteen years since collectivisation had begun to occur, left neighbouring farms with fundamentally similar potential for production at vastly different stages of development and different degrees of financial security looking forward to an uncertain future. Given these differences in past development, collective farmers could have very different conceptions of how their best interests were to be served. There is no doubt that many Type III LPGs benefited from leading the way in economic reform, gaining in status as well as material reward. On the other hand, successful LPGs were understandably loath to alter what appeared to be a well-functioning organisation. Equally, the members of struggling LPGs were not always open to the latest measures, fearing further reductions in their incomes or still less control over their farm as a result. The problems faced by state functionaries suggesting alterations to farmers' ways of working over the last ten years were well summed up by a former functionary in the state agricultural apparatus: 'How often have I personally had to hear in the thirteen years of my employment in the State apparatus as I gave good advice in the farms: "it's all right for you to talk, you get good money anyway".",59 As long as LPG members and LPG functionaries were uncertain what economic reform entailed for their future prosperity as stakeholders in their LPG, they remained unpersuaded of the value of change.

In practice, however, giving security to the LPGs with regard to their future development was not easily achieved. The beginnings of an economic meltdown in the economy at large in 1968 undermined the validity of long-term economic planning. Not for the first time and certainly not the last, LPG members complained that they were being made to bear the brunt of an increase in prices for the sake of industry. Despite the supposed existence of buffers, which reduced some of the prices charged LPGs for essential products from industry, there appeared to have been a systematic increase across the board for the machines, equipment and materials required for LPGs to develop industrial-scale production. Any savings on costs as a result of a reduction in manpower were reportedly being outweighed by excess costs for material and machinery. ${ }^{60}$ 
A report by the Agricultural Council of the GDR in March 1968 on the mood in the LPGs pointed to a number of perceived injustices that were causing anger among farmers around the country. LPG chairmen found that they were unable to meet the rising costs of production with the income from the sale of their produce. In other words, industrial prices appeared to be rising faster than the prices and bonuses paid for increased deliveries of agricultural produce. On top of this farmers complained they were not even getting value for money. Despite the raised prices there appeared to be no guarantee of availability as far as the provision of machinery and tools was concerned. Any long-term planning or contractual supply even for the coming year was out of the question. Just to add insult to injury, some of the machines with which farmers had been supplied were found to be faulty. ${ }^{61}$

The degree of concern among collective farmers over their future status in agriculture was highlighted by discussion of the new national constitution to be introduced in 1968. Article 13 of the proposed constitution appeared to describe the products produced by collective farming of the soil as collective property. Given that livestock owned privately by Type I farmers relied on the crops farmed collectively, some LPG members in Bezirk Erfurt reportedly expressed fears that the produce from their individual livestock farming could now be construed as collective property. More seriously, farmers in general voiced questions as to whether the development of cooperation between LPGs, particularly in crop production, signalled the end to the distinction between collective use, yet private ownership of land - a de facto expropriation of farmers. ${ }^{62}$

For Type III LPGs which had struggled for years to achieve better results without success, there was, too, a good deal of scepticism towards making changes without a clear prospect for the long-term future. In the LPG Type III in Buttstädt, for example, farmers responded to attempts to interest them in discussion of the upcoming national referendum on the constitution with a straightforward refusal, unless somebody came to give them a clear indication of how they were to be helped to develop: 'first there must be clarity about our future, then we'll talk about other problems'. ${ }^{63}$

\section{A Changing Context for SED Authority}

By 1968 much had been changed already in socialist agriculture. The number of Type I LPGs had been reduced to less than the number of Type III LPGs in most of the districts of the Bezirk. As the size of the ag- 
ricultural workforce had declined, levels of qualification had risen significantly (see Figure 5.1) ${ }^{64}$ The percentage of LPG members in Bezirk Erfurt who belonged to the SED rose too from a paltry 6.9 per cent in $1962^{65}$ to 14.2 per cent in $1968 .^{66}$

Much, too, had been achieved in establishing the conditions for mechanised production on a large scale, with mergers and some forms of cooperation taking effect. Despite resistance to the NÖS, in many LPGs performance-related pay, bonuses and detailed accounting of costs and profits were an accepted part of the production process. The trappings of collective democracy - meetings of LPG commissions, weekly board meetings, plenary members' assemblies and particularly brigade assemblies - had to some extent become a routine part of the functioning of the LPGs, essential to the sharing of information and the transmission of authority within the collective farm. There had, however, by no means been uniform progress across all the districts of the Bezirk in the development of cooperative relations, the implementation of economic reform or indeed the improvement of productivity. There were still a number of struggling Type III LPGs and Type I LPGs whose members despaired of the future, particularly in the uplands in the north and west of the Bezirk. Moreover, the evolution of working conditions in livestock production was still very differentiated between LPGs. ${ }^{67}$

A survey of opinion by the SED Central Committee's Institute for Research into Popular Opinion among farmers in a number of LPGs from each of the Bezirke in the GDR in 1967 illustrated clear limits to the extent to which collectivised farming had been embraced by a considerable proportion of farmers. Although technological improvements

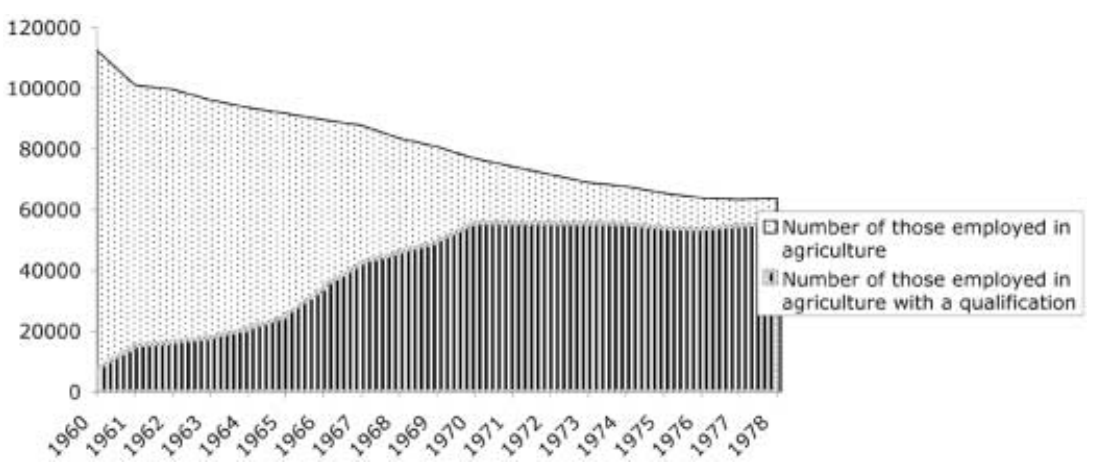

Figure 5.1 Convergence of rising qualification levels and declining workforce in Bezirk Erfurt, 1960-78

Source: Staatliche Zentralverwaltung für Statistik, Bezirksstelle Erfurt, Statistisches Jahrbuch, Bezirk Erfurt 1961-1979, Erfurt, 1962-80. 
were broadly welcomed, collective farming had clearly failed to convince many farmers that they were in a better position than they had been as private landowners. Only 5.5 per cent of respondents from the LPG Oberreissen in Bezirk Erfurt agreed that they enjoyed their work more today in the LPG than they had prior to collectivisation. Most respondents in all four LPGs surveyed in Bezirk Erfurt, as well as in the average for the GDR as a whole, agreed with the statement that work gave them as much pleasure today as it did before. Very few respondents valued the work organisation in their LPG or regarded personal income as a benefit of collectivisation - in the rest of the GDR as in Bezirk Erfurt fewer than half of the respondents recognised any other benefits than improved access to modern machinery. ${ }^{68}$

Nevertheless, identification with the LPG appears also to have grown among all farmers, not least perhaps given the futility of continuing to hark back to the days of private farming. While concessions continued to be made to farmers in the form of household plots and livestock, working conditions had changed considerably. Many (although not all) residual elements of private farming had been replaced with a collective working culture. ${ }^{69}$ As a woman farmer in the LPG Bachra, Kreis Sömmerda described at a district farmers' conference in May 1968: 'the brigade members do not just produce together, they spend a part of their spare time in the work collective. Group trips, events and discussion are a fixed part of life in the Brigade... ${ }^{70}$ At the same conference a member of the LPG Schillingstedt offered his conception of the transformation over the last ten years. Ten years ago 'that was still my field and my animal and it became only later gradually our field and our animal and today it is a matter of course that every individual thinks collectively' ${ }^{71}$

Of course this sentiment was not shared by all collective farmers; nonetheless it seems that increasingly the LPG did provide formerly private farmers with a new sense of identity. Shortly before the VIII SED Party Congress, a survey was carried out by the Institute for Social Sciences at the $\mathrm{ZK}$. Asked whether they felt personally connected with their LPG, 81.4 per cent of the 2,462 respondents to this question agreed. When questioned as to the main changes which they considered to have taken place among the people during the development of the LPG, far and away the most popular answer was the level of qualification. Second highest was the 'development of comradely collaboration and mutual aid between colleagues' ${ }^{72}$ Some of the essential changes associated with the development of agriculture, such as technical education and collective work practices, appeared thus to have had an impact on the way farmers perceived themselves. 


\section{Conclusion}

It was certainly true that by this stage SED party organisations had made significant strides not only in the quantity but also in the quality of their members in the farming community in the Bezirk. Technical training had also gone hand in hand with political conformity. The positive benefits of collective farming had begun to become visible and more and more farmers were being incorporated through technical training and qualification into a socialist system of modern agriculture which promoted cooperation. Nevertheless, considerable persuasion was required still to win over even loyal leading functionaries in the LPGs, let alone sceptical mid-level cadres and the majority of rank-and-file collective farmers, to the next steps in the development of agriculture. Fear of future expropriation and redundancy, loss of independence and subordinate status loomed large in farmers' responses to the rate at which change was supposed to occur in agriculture. The mechanisation, specialisation and concentration of production on an industrial scale promised exciting and dramatic improvements in productivity as well as working and living conditions in rural communities. However, such developments also cast doubt over the future status and security of work in agriculture and life in the village for all members of the collective farms.

\section{Notes}

1. ThHStAW Bezirksparteiarchiv der SED Erfurt, Kreisleitung der SED Sömmerda IV/A/4.10/077 SED Kreisleitung Sektor Parteiinformation, Informationsbericht laut Arbeitsplan, 4.4.1966, p. 247.

2. 'Groß LPG' was often (though not always) a pejorative label given to LPGs which had been formed or expanded through merger to an extraordinary size, retaining unified administration of both arable and livestock production.

3. Examples of LPG members' opinions to this effect may be found in $\mathrm{ThH}-$ StAW Bezirksparteiarchiv der SED Erfurt, Bezirksleitung der SED Erfurt IV/B/2/2-022 Protokoll der Bezirksparteiaktivtagung zu den Fragen und Aufgaben der soz. Landwirtschaft am 7.3.1968 Beitrag Genossin Zessin, p. 103; Bezirksparteiarchiv der SED Erfurt, Bezirksleitung der SED Erfurt IV/ B/2/13-378 SED Bezirksleitung, Einschätzung über das Einwohnerforum in der Grenzgemeinde Berka/Werra Kr. Eisenach, 27.1.1969, p. 1.

4. ThHStAW Bezirksparteiarchiv der SED Erfurt, Bezirksleitung der SED Erfurt IVA/2/3-112 Bezirkslandwirtschaftsrat, Der Vorsitzende u. Prod.leiter an das Sekretariat der Bezirksleitung der SED Betr: Schlussfolgerungen zur Verallgemeinerung der Erfahrungen bei der Herstellung kooperativer Beziehungen im Bereich Obernissa, 18.3.1965, p. 33. 
5. ThHStAW Bezirksparteiarchiv der SED Erfurt, Bezirksleitung der SED Erfurt IV/A/2/2-042 Sekretariat der Bezirksleitung, Protokoll der Bezirksparteiaktivtagung Landwirtschaft am 18.12.1964 Referat (unnamed), p. 70 .

6. ThHStAW Bezirksparteiarchiv der SED Erfurt, Bezirksleitung der SED Erfurt IV/A/2/3-122 SED Kreisleitung Nordhausen, Bericht über die Entwicklung der massenpolitischen Arbeit ... 25.6.1965, p. 20.

7. ThHStAW Bezirksparteiarchiv der SED Erfurt, Bezirksleitung der SED Erfurt IV/A/2/3-112 Bezirkslandwirtschaftsrat, Schlussfolgerungen zur Verallgemeinerung ... 18.3.1965, p. 31.

8. ThHStAW RdB Erfurt L1082 Bezirkslandwirtschaftsrat, Produktionsleitung, Kurzanalyse über den Kreis Erfurt-Land, Bereich Landwirtschaft, undated 1965.

9. ThHStAW Bezirksparteiarchiv der SED Erfurt, Bezirksleitung der SED Erfurt IV/A/2/2-043 Sekretariat der Bezirksleitung, Protokoll der Bezirksparteiaktivtagung Landwirtschaft am 7.12.1965, Referat Genosse Bräutigam, p. 176.

10. ThHStAW Bezirksparteiarchiv der SED Erfurt, Bezirksleitung der SED Erfurt IV/A/2/3-112 Bezirkslandwirtschaftsrat, Einschätzung der Kreisbauernkonferenzen im Bezirk Erfurt, Schlussfolgerungen, p. 152.

11. ThHStAW Bezirksparteiarchiv der SED Erfurt, Bezirksleitung der SED Erfurt BIV/2/5-382 SED Bezirksleitung Abt. Parteiorgane, Informationsbericht Nr. 16/65, 29.5.1965, p. 181.

12. ThHStAW Bezirksparteiarchiv der SED Erfurt, Bezirksleitung der SED Erfurt BIV/2/5-382 SED Bezirksleitung Abt. Parteiorgane, Informationsbericht Nr. 26/65, 19.8.1965, p. 333.

13. ThHStAW Bezirksparteiarchiv der SED Erfurt, Bezirksleitung der SED Erfurt IV/A/2/2-042 Sekretariat der Bezirksleitung, Protokoll der Bezirksparteiaktivtagung Landwirtschaft am 7.12.1965, pp. 2, 160.

14. ThHStAW Bezirksparteiarchiv der SED Erfurt, Bezirksleitung der SED Erfurt IV/A/2/2-043 Sekretariat der Bezirksleitung, Protokoll der Bezirksparteiaktivtagung Landwirtschaft am 7.12.1965, Referat Genosse Lüdecke, p. 2.

15. ThHStAW Bezirksparteiarchiv der SED Erfurt, Bezirksleitung der SED Erfurt BIV/2/7-547 SED Bezirksleitung Abt. Landwirtschaft, Einschätzung der Führungs- und Leitungstätigkeit ... 11.11.1965, p. 41.

16. ThHStAW Bezirksparteiarchiv der SED Erfurt, Bezirksleitung der SED Erfurt BIV/2/7-588 Bezirksvorstandes der DBD, Bericht über die Entwicklung von Kooperationsbeziehungen ... 25.11.1965, p. 23.

17. ThHStAW Bezirksparteiarchiv der SED Erfurt, Bezirksleitung der SED Erfurt IV/A/2/2-043 Sekretariat der Bezirksleitung, Protokoll der Bezirksparteiaktivtagung Landwirtschaft am 7.12.1965, Referat Genosse Dyballa, p. 160.

18. ThHStAW Bezirksparteiarchiv der SED Erfurt, Bezirksleitung der SED Erfurt IV/A/2/3-144 Sekretariat der Bezirksleitung, Abt. Landwirtschaft Vorlage an das Sekretariat, Ergänzung zum Beschluss des Sekretariates der BL Nr. 995 vom 16.12.1965 zur Vorbereitung des IX. Deutschen Bauernkongresses. Massnahmeplan, pp. 39-51. 
19. Five out of 475 Type III LPGs were less than 100 hectares and 135 Type III LPGs less than 300 hectares in size. ThHStAW Bezirksparteiarchiv der SED Erfurt, Bezirksleitung der SED Erfurt BIV/2/7-588 Bezirksvorstandes der DBD, Bericht über die Entwicklung von Kooperationsbeziehungen ... 25.11.1965, p. 23.

20. ThHStAW Bezirksparteiarchiv der SED Erfurt, Bezirksleitung der SED Erfurt BIV/2/5-382 SED Bezirksleitung Abt. Parteiorgane, Informationsbericht Nr. 16/65, 29.5.1965, pp. 181-91.

21. ThHStAW Bezirksparteiarchiv der SED Erfurt, Bezirksleitung der SED Erfurt BIV/2/7-565 SED Bezirksleitung Abt. Landwirtschaft, Einschätzungen über die Vorbereitungen der Neuwahlen bzw. Ergänzungswahlen in den Genossenschaften des Bezirkes Erfurt, 10.12.1965, pp. 206-9.

22. ThHStAW Bezirksparteiarchiv der SED Erfurt, Bezirksleitung der SED Erfurt BIV/2/3-278 SED Kreisleitung Nordhausen, Bericht über die Lage und die eingeleitete Massnahmen zur Veränderung und Verbesserung der genossenschaftlichen Arbeit in der LPG Typ III 'Rotes Banner' Ellrich, 31.7.1963, pp. 2-8.

23. ThHStAW Bezirksparteiarchiv der SED Erfurt, Bezirksleitung der SED Erfurt IV/A/2/2-043 Sekretariat der Bezirksleitung, Protokoll der Bezirksparteiaktivtagung Landwirtschaft am 7.12.1965, Referat Genosse Kummer, p. 131.

24. ThHStAW Bezirksparteiarchiv der SED Erfurt, Kreisleitung der SED Sömmerda IV/A/4.10/097 Abt. Parteiorgane an die Bezirksleitung, Ergänzung zur Kreisanalyse über die Kampfkraft der Partei laut Fernschreiben Nr. 26 vom 15.1.1966, 19.1.1966, pp. 41-54.

25. ThHStAW Bezirksparteiarchiv der SED Erfurt, Bezirksleitung der SED Erfurt IV/A/2/3-159 SED Kreisleitung Worbis, Bericht über die Führung der polit-ideologischen Arbeit ... 3.6.1966, p. 29.

26. SAPMO BArch DY30 IV A 2/2.023/147 Büro Gerhard Grüneberg, Material über Erfahrungen der Parteiarbeit im Bezirk Erfurt zur Lösung der ideologischen Fragen bei der Entwicklung von Kooperationsbeziehungen in der sozialistischen Landwirtschaft, 4.5.1966; ThHStAW Bezirksparteiarchiv der SED Erfurt, Bezirksleitung der SED Erfurt IV/A/2/3-150 Sekretariat der Bezirksleitung, Entwurf des Berichtes an das Sekretariat des ZK über 'Die Erfahrungen der Parteiarbeit speziell zur Lösung der ideologischen Fragen bei der Entwicklung von Kooperationsbeziehungen', pp. 37-55.

27. ThHStAW Bezirksparteiarchiv der SED Erfurt, Bezirksleitung der SED Erfurt IV/A/2/3-159 SED Bezirksleitung Abt. Landwirtschaft, Stellungnahme zum Massnahmeplan des Rates des Bezirks ...13.6.1966, p. 132.

28. ThHStAW Bezirksparteiarchiv der SED Erfurt, Bezirksleitung der SED Erfurt IV/A/2/3-169 SED Bezirksleitung Abt. Parteiorgane, Informationsbericht Nr. 19/66, 24.8.1966, p. 31; IV/A/2/3-169 SED Bezirksleitung Abt. Parteiorgane, Einschätzung des Standes des soz. Bewusstseins der Bevölkerung unseres Bezirkes ... 8.9.1966, p. 79.

29. ThHStAW Bezirksparteiarchiv der SED Erfurt, Bezirksleitung der SED Erfurt IV/A/2/3-159 SED Bezirksleitung Abt. Agit./Prop, Stellungnahme der Bezirksleitung zur Berichterstattung des Sekretariats der SED Kreisleitung Worbis, 13.6.1966, p. 28. 
30. E.g. ThHStAW Bezirksparteiarchiv der SED Erfurt, Bezirksleitung der SED Erfurt IV/B/2/5-161 SED Bezirksleitung Abt. Landwirtschaft, Handmaterial zur Berichterstattung des Sekretariats der SED Kreisleitung Sömmerda vor dem Sekretariat in der Land- und Nahrungsgueterwirtschaft, 7.5.1968, p. 57. For a dramatic representation of such conflicts of interest see: H. Sakowski, Daniel Druskat, East Berlin, 1976.

31. ThHStAW Bezirksparteiarchiv der SED Erfurt, Bezirksleitung der SED Erfurt BIV/2/7-550 SED Bezirksleitung Abt. Parteiorgane Erfahrungen und Schlussfolgerungen ... 3.11.1965, p. 100; BIV/2/5-384 SED Bezirksleitung Abt. Parteiorgane, Information 27.9.1966, pp. 256-8; BIV/2/7-588 SED Bezirksleitung Abt. Landwirtschaft, Einschätzung des Kooperationsbereiches Walschleben, 6.7.1966, pp. 145-54; SED Bezirksleitung Abt. Landwirtschaft, Abt. Parteiorgane, Faktenmaterial zu einigen Problemen der Partei und Massenarbeit der PO der Kooperationsgemeinschaft Walschleben, 23.11.1966, pp. 174-7.

32. ThHStAW Bezirksparteiarchiv der SED Erfurt, Bezirksleitung der SED Erfurt BIV/2/7-588 SED Bezirksleitung Abt. Landwirtschaft, Protokoll über den Erfahrungsaustausch am 28.3.1967 in Heringen, 11.4.1967, pp. 320-48.

33. ThHStAW Bezirksparteiarchiv der SED Erfurt, Bezirksleitung der SED Erfurt BIV/2/7-557 SED Bezirksleitung Abt. Landwirtschaft der Bezirksleitung, Bericht über den Einsatz im Kreis Apolda, 9.8.1967, pp. 72-76; Kreisleitung der SED Sömmerda IV/A/4.10/077 SED Kreisleitung Sömmerda, Parteiorgane, Einschätzung der MV, 10.9.1967, pp. 50-57; SED Kreisleitung Sömmerda, Parteiorgane, Einschätzung der MV, 5.10.1967, pp. 58-63; SED Kreisleitung Sömmerda, Parteiorgane, Einschätzung der MV, 27.11.1967, pp. 74-81.

34. Examples of LPG members' opinions to this effect may be found in ThHStAW Bezirksparteiarchiv der SED Erfurt, Bezirksleitung der SED Erfurt IV/B/2/2-022 Protokoll der Bezirksparteiaktivtagung zu den Fragen und Aufgaben der soz. Landwirtschaft am 7.3.1968 Beitrag Genossin Zessin, p. 103; Bezirksparteiarchiv der SED Erfurt, Bezirksleitung der SED Erfurt IV/B/2/13-378 SED Bezirksleitung Abt. Landwirtschaft, Einschätzung über das Einwohnerforum in der Grenzgemeinde Berka/Werra Kr. Eisenach, 27.1.1969, p. 1.

35. BStU Aussenstelle Erfurt, 1584/84 Kreisdienststelle Erfurt, Werbung des IMS 'Max', ?.7.1967, p. 23.

36. ThHStAW RdB Erfurt L014542 Rat für Landwirtschaft und Nahrungsgüterwirtschaft (Bezirk), Analyse über den Anfall von Altersbetrieben in den LPG des Typ I und II in den nächsten Jahren und Vorschläge von Massnahmen zum Auffangen der Produktion, 1969.

37. ThHStAW Bezirksparteiarchiv der SED Erfurt, Bezirksleitung der SED Erfurt IV/B/2/5-161 SED Bezirksleitung Abt. Parteiorgane, Wocheninformation zu einigen Problemen der Führungstätigkeit des Sekretariats der SED Kreisleitung Sömmerda, 26.3.1968, p. 24.

38. ThHStAW Bezirksparteiarchiv der SED Erfurt, Bezirksleitung der SED Erfurt IV/A/2/3-186 Sekretariat der Bezirksleitung, Thesen für den Bericht der Bezirksleitung an die Bezirksdelegiertenkonferenz, p. 42.

39. ThHStAW Bezirksparteiarchiv der SED Erfurt, Bezirksleitung der SED 
Erfurt BIV/2/3-278 SED Kreisleitung Erfurt-Land an den Genossen Bräutigam, Informationsbericht, 14.11.1967, p. 389.

40. ThHStAW Bezirksparteiarchiv der SED Erfurt, Kreisleitung der SED Sömmerda IV/A/4.10/077 SED Kreisleitung Sektor Parteiinformation, Informationsbericht laut Arbeitsplan, 1.2.1966, p. 238.

41. ThHStAW Bezirksparteiarchiv der SED Erfurt, Bezirksleitung der SED Erfurt BIV/2/3-278 SED Kreisleitung Nordhausen an den Genossen Bräutigam, Informationsbericht 16.10.1967, p. 317.

42. ThHStAW Bezirksparteiarchiv der SED Erfurt, Kreisleitung der SED Sömmerda IV/A/4.10/077 SED Kreisleitung, Abt. Parteiorgane - Sektorparteiinformation, Einschätzung der Mitgliederversammlungen Januar, 1.2.1967, pp. 3-10; Sektor parteiinformation, Einschätzung der MV im Monat August, 10.9.1967, p. 56.

43. ThHStAW Bezirksparteiarchiv der SED Erfurt, Bezirksleitung der SED Erfurt IV/B/2/5-161 SED Bezirksleitung Abt. Parteiorgane, Faktenmaterial für die Berichterstattung des Sekretariats der SED Kreisleitung Sömmerda, 8.5.1968, p. 59.

44. SAPMO BArch DY30 IV A 2/2.023/72 Büro Gerhard Grüneberg, ZK der SED Abt. Landwirtschaft, Einige weitere Probleme, die aus den KBK sichtbar werden 8.5.1968.

45. ThHStAW Bezirksparteiarchiv der SED Erfurt, Kreisleitung der SED Sömmerda IV/B/4.10/101 SED Kreisleitung Abt. Parteiorgane, Einschätzung der MV - Monat Juli, 5.8.1968, p. 39.

46. ThHStAW Bezirksparteiarchiv der SED Erfurt, Kreisleitung der SED Sömmerda IV/B/4.10/101 SED Kreisleitung Abt. Parteiorgane, Einschätzung der MV - Monat August, 30.8.1968, p. 50.

47. ThHStAW Bezirksparteiarchiv der SED Erfurt, Kreisleitung der SED Sömmerda IV/A/4.10/077 SED Kreisleitung Abt. Parteiorgane Sektor Parteiinformation, Einschätzung der MV im Monat September, 5.10.1967, pp. 58-63.

48. ThHStAW Bezirksparteiarchiv der SED Erfurt, Kreisleitung der SED Sömmerda IV/A/4.10/077 SED Kreisleitung Abt. Parteiorgane Sektor Parteiinformation, Einschätzung der MV Monat November, 27.11.1967, pp. 7481.

49. SAPMO BArch DY30/IV A 2/15/103 ZK der SED, Abt. Befreundete Organisationen, Die ideologische Situation in der DBD vor den Volkskammerwahlen, 1963.

50. SAPMO BArch DY30/IV A 2/15-103 ZK der SED, Abt. Befreundete Organisationen Sekretariat des Parteivorstandes der DBD, Analyse über die Entwicklung der Leitungstätigkeit der Vorstände und des sozialistischen Bewusstsein der Mitglieder seit unserem VII. Parteitag, 23.2.1968.

51. For example ThHStAW Bezirksparteiarchiv der SED Erfurt, Bezirksleitung der SED Erfurt IV/B/2/9.02-289 SED Kreisleitung Eisenach, Fernschreiben, Information über die Gemeinde Dippach.,14.8.1968, p. 48.

52. ThHStAW Bezirksparteiarchiv der SED Erfurt, Bezirksleitung der SED Erfurt IV/B/2/5-410 SED Kreisleitung Eisenach an die Bezirksleitung der SED, Einschätzung über die Kreisdelegiertenkonferenz der DBD am 12.1.1968 in Eisenach, 1.2.1968, p. 42.

53. ThHStAW Bezirksparteiarchiv der SED Erfurt, Bezirksleitung der SED Erfurt IV/B/2/2-022 Protokoll der Bezirksparteiaktivtagung zu den Fragen 
und Aufgaben der soz. Landwirtschaft 7.3.1968, Referat des Genossen Lüdecke, p. 3.

54. SAPMO BArch DY30/IV A 2/2.023/220 Büro Gerhard Grüneberg, Protokoll der Kreisbauernkonferenz Weimar am 18 und 19.4.1968, Referat Gen. Schüffler, Produktionsleiter und Vorsitzender des Kreislandwirtschaftsrat.

55. ThHStAW Bezirksparteiarchiv der SED Erfurt, Bezirksleitung der SED Erfurt IV/B/2/5-165 SED Bezirksleitung Abt. Parteiorgane, Information über einige Probleme aus der operativen Tätigkeit, 23.7.1968, p. 112.

56. ThHStAW Bezirksparteiarchiv der SED Erfurt, Kreisleitung der SED Sömmerda IV/B/4.10/197 Abt. Landwirtschaft, Kreisbauernkonferenz am 3. und 4. Mai 1968, Diskussionsbeitrag Otto Köhler, Kleinhausen Typ I, pp. 158-65.

57. ThHStAW Bezirksparteiarchiv der SED Erfurt, Bezirksleitung der SED Erfurt IV/B/2/5-165 SED Bezirksleitung Abt. Parteiorgane, Information zu Führungsproblemen der Sekretariate der Kreisleitungen ... 16.7.1968, p. 105.

58. SAPMO BArch DY30/IV A 2/2.023/220 Büro Gerhard Grüneberg, Protokoll der Kreisbauernkonferenz Weimar am 18 und 19.4.1968, Diskussionsbeitrag Helmut Seidel, Vorsitzender LPG Typ II Saalborn.

59. ThHStAW Bezirksparteiarchiv der SED Erfurt, Kreisleitung der SED Sömmerda IV/B/4.10/197 SED Kreisleitung Abt. Landwirtschaft, Kreisbauernkonferenz am 3. und 4. Mai 1968, Diskussionsbeitrag Walter Schreck, KOG Frömmstedt, pp. 144-50.

60. SAPMO BArch DY30 IV A 2/2.023/72 Büro Gerhard Grüneberg, ZK der SED Abt. Landwirtschaft, Einige weitere Probleme, die aus den KBK sichtbar werden 8.5.1968.

61. BArch, DK 1 VA Neu 2846 Landwirtschaftsrat der DDR, Information zum Verlauf der Frühjahrsbestellung sowie Kritiken, Hinweise und Anfragen, 22.3.1968.

62. BArch, DK 1 VA Neu 2846 Landwirtschaftsrat der DDR, Information zu einigen Problemen der Verfassungsdiskussion in den sozialistischen Betrieben der Landwirtschaft, 1.3.1968.

63. ThHStAW Bezirksparteiarchiv der SED Erfurt, Bezirksleitung der SED Erfurt IV/B/2/5-161 SED Bezirksleitung Abt. Parteiorgane, Ergänzung zu Problemen der Führungstätigkeit im Kr. Sömmerda, 15.4.1968, p. 33.

64. By 1968 the proportion of the agricultural workforce with the basic qualification (Facharbeiterprüfung) was at 47 per cent. The proportion of those qualified as master farmers, or with a technical college or university qualification, was at 7.8 per cent. Staatliche Zentralverwaltung für Statistik, Bezirksstelle Erfurt, Statistisches Jahrbuch, Bezirk Erfurt 1970, Vol. I, Erfurt. 1971, p. 126.

65. ThHStAW Bezirksparteiarchiv der SED Erfurt, Bezirksleitung der SED Erfurt IV/A/2/3-186 SED Bezirksleitung Abt. Parteiorgane, Analyse der Mitgliederbewegung im Jahre 1966, 9.1.1967, pp. 142-63.

66. SAPMO BArch DY 30/1794 ZK der SED Abt. Landwirtschaft, Anzahl der Mitglieder und Kandidaten der Partei zu den Gesamtmitgliedern in den LPG Typ I, II und III, 1969, p. 44.

67. For example ThHStAW Bezirksparteiarchiv der SED Erfurt, Bezirksleitung der SED Erfurt IV/B/2/9.01-289 SED Kreisleitung Erfurt-Land, Grup- 
penaussprache mit Mitgliedern der Viehwirtschaftsbrigade, Kerspleben, 1.11.1968, p. 79.

68. SAPMO BArch DY30/IV A 2/2.023/82 Büro Gerhard Grüneberg, Genosse Norden an Grüneberg, Material des Instituts für Meinungsforschung über einige Probleme der sozialistischen Landwirtschaft, 24.4.1967.

69. Private home production (individuelle Hauswirtschaften) remained central to life as a collective farmer and was a crucial means of supplementing income. It also came to be essential to the production of certain items of produce for the GDR as a whole from the late 1970s. See, for an example of the meaning of the individuelle Hauswirtschaft to members of an LPG, B. Schier, Alltagsleben im 'Sozialistischen' Dorf, Münster, 2001, pp. 223-37.

70. ThHStAW Bezirksparteiarchiv der SED Erfurt, Kreisleitung der SED Sömmerda IV/B/4.10/197 Abt. Landwirtschaft, Kreisbauernkonferenz am 3. und 4. Mai 1968, Diskussionsbeitrag Kollegin Krempl - LPG Bachra, p. 184.

71. ThHStAW Bezirksparteiarchiv der SED Erfurt, Kreisleitung der SED Sömmerda IV/B/4.10/197 Abt. Landwirtschaft, Kreisbauernkonferenz am 3. und 4. Mai 1968m Diskussionsbeitrag Koll. Tettenborn, LPG Schillingstedt, p. 187.

72. SAPMO BArch DY30/IV A 2/2.023/83 Büro Gerhard Grüneberg, Institut für Gesellschaftswissenschaften beim ZK der SED, Lehrstuhl marxistischleninistische Soziologie, Einschätzung und Wertung der Beantwortung der Fragen 1-21 und der Rangfolge der Vorgaben in diesen Fragen (nach ihrer Häufigkeit) aus der schriftlichen Befragung der Genossenschaftsbauern ... 17.2.1971. 


\section{of 6}

\section{Critical Transitions}

From 1969 we'll carry out crop production in common with the LPG Type III ... What do you want from us now, we produce well. We have a high production; we have what we need and we're doing fine ... ${ }^{1}$

(LPG Type I members in Burgtonna, Kreis Bad Langensalza make clear their lack of enthusiasm for developing advanced cooperation in crop production in February 1968.)

The solutions to the issue of cooperation are more difficult or rather more grave than was the formation of the LPGs. ${ }^{2}$

(Comments made by leading agricultural functionaries in discussion in Kreis Mühlhausen in October 1968.)

Much had been achieved during the 1960s in transforming agriculture in the GDR and changing the context in which agricultural policy was implemented. More LPG chairmen were technically trained and politically loyal. SED party secretaries and SED party organisations were becoming increasingly influential. An ever-increasing proportion of LPG members were achieving qualifications in socialist agricultural methods, learning specialist trades and, at more advanced levels, learning the techniques of socialist agricultural management and economics. Moreover, with the continuing absorption of Type I LPGs into Type III LPGs and the development of collective livestock herds, greater centralisation of farm management increased the uniformity and consistency with which the SED leadership was able to communicate its authority over the front line of production. Arguably by the end of the 1960s there had been some internalisation of the norms of socialist, collectivised and industrialised agriculture among the agricultural workforce alongside a stabilisation and routinisation of the structures of agricultural administration. These processes of transformation had, however, by no means been consistent or comprehensive in their scope and rested on fragile foundations.

There remained in 1968 a considerable gulf between the theoretical degree of agriculture's development in the GDR and the actual extent to which individual LPGs were prepared to evolve. As had been too often demonstrated, there were limits to the speed with which reforms 
could be imposed on reluctant collective farmers without damaging production and alienating a proportion of the population which was only just beginning, literally and metaphorically, to come to terms with the SED regime's latest great intervention in their working lives. There were also limits to the ability of the economy as a whole to provide the investment needed to sustain the speed of this transformation. Finally, there were limits to the certainty of LPG functionaries as to which path of development was likely to be the most effective means of reaching the ultimate goal of a cost-efficient mechanised, concentrated and industrial-scale agriculture.

In 1968 and 1969 some LPGs were indeed marching forward - but not all were following the same path. Many LPGs, particularly Type I LPGs, were standing resolutely still, while the vast majority were being jostled and cajoled into more or less reluctant steps towards an uncertain future.

\section{Forced Evolution}

Since the late 1950s a considerable amount had been achieved in transforming the living conditions and working practices of villagers and farmers. It remained the case, however, that the zeal of district party functionaries for transforming the fundamental organisation of agriculture in the country did not correspond to the willingness or the ability of a large proportion of LPG managers, let alone the members at large, to accept change at such a rapid rate. At the same time agriculture, owing to its reliance more than ever on machinery, fuel and electricity, was becoming increasingly subject to growing inefficiencies in the rest of the economy. Bottlenecks in the supply of essential products from industry to agriculture were beginning in 1968 to have an impact on the efficiency of farming in Bezirk Erfurt.

The circumstances were thus by no means auspicious for any attempts to introduce a new pattern of agricultural organisation. The year 1968, however, saw the SED leadership call for far-reaching change in the status of the LPG as it was within the GDR's economic system. In particular, the VII Party Congress of the SED in 1967 and the X German Farmers' Congress in 1968 set a new agenda for the development of collective farming in the GDR, advocating the deepening of cooperative relations between LPGs, above all in crop production, and no less significantly the development of new structures regulating the LPGs' supply of produce for public consumption. Attempts to force a rapid evolution of agricultural organisation, however, served only to demon- 
strate how fragile the structures for communicating the authority of the SED leadership in rural society could be.

Speaking in March 1968 at the SED Bezirkparteiaktivtagung, the Secretary for Agriculture in the SED Bezirksleitung had stressed the need for ideological persuasion of LPG members before steps were taken in the formation of advanced cooperative relations between LPGs. ${ }^{3}$ As a farmer from an LPG Type I in Kreis Sömmerda was reported to have said with regard to suggestions of permanent cooperation in crop production: 'It would be very easy ... to make the whole thing law with a resolution. That would however be a breach of inner collective democracy and would erase the fact that "all power comes from the people".' As it was, the people - in this case collective farmers, particularly in the Type I LPGs - remained deeply sceptical of any measure which appeared to change their status. The development of permanent cooperation in crop production between two or more LPGs appeared to entail far-reaching changes to rights of ownership of land and also to the independent status of individual collective farms. It appeared, moreover, to sever the traditional connection between livestock and crop farming, which was something which farmers and agricultural functionaries in the state administration alike found hard to countenance. ${ }^{4}$

Ulbricht's comments at the X German Farmers' Congress in 1968 were crucial inspiration for action to be taken by the KLRs to put renewed pressure on LPG chairmen to commit their farms to the rapid development of permanent cooperation in crop production. He appeared to announce that the structure of farming had to be - and would be - transformed in order to take advantage of the latest scientific and technological developments, which would in turn transform 'the social organisation of production'. More clearly than ever before, it was articulated that traditional ideas of maintaining mixed crop and livestock farms - whatever the size - had no place in the future of agriculture in the GDR. In Ulbricht's own words: 'relatively ever more independent large production units for crop production and for the different branches of livestock production will gradually develop'. Cooperation was confirmed as no mere temporary solution but the essential link in the chain of future agricultural development. ${ }^{5}$

At the same time, a radical change to the status of agriculture within the economy was announced. The solution to the problem of integrating agriculture into a more flexible demand-orientated planned economic system was sought in the formation of a new administrative body designed to regulate agriculture in conjunction with the food industry. At the X German Farmers' Congress in July 1968 it was proposed therefore that the agricultural councils (Landwirtschaftsräte) were expanded to in- 
clude representatives of the food industries (Räte für Landwirtschaft und Nahrungsgüterwirtschaft or RLNs). As a unified administration in the districts and the Bezirke the RLNs would, it was hoped, be able to oversee the coordinated development of agricultural organisation in line with the demands of the various food industries for industrial-scale, specialised production of certain agricultural products.

In order to coordinate and fund the construction of the necessary facilities for this development, so-called cooperative unions (Kooperationverbände or KOVs) were formed to coordinate farms with the food processing and distribution industries. With the growth of so-called vertical cooperation between LPGs and the food industry, reflected in administrative terms by the formation of the KOVs, the long-term goal of transforming agriculture into a controllable and therefore somewhat more predictable branch of the wider economy appeared in theory to be rapidly approaching.

The actual prospects for implementing this vision of modern agriculture and responsive economic planning any time soon were rather slim. Attempts to introduce material incentive and closer economic regulation through strict cost analysis and socialist competition into the LPGs during the 1960s had been intended not only to stimulate production but also to enable the regulation of different strands of agricultural production more efficiently. Under the New Economic System, rather than being defined by economic planners in the state administration, agricultural development - i.e. the specialisation and concentration of production - was ultimately to be orchestrated directly according to the priorities set by those industries which relied on agricultural produce to function. ${ }^{6}$ Agricultural production was thus to be flexibly controlled according to contracts established between the food processing industries - the so-called final producers who were best placed to gauge demand for particular produce - and the LPGs. The efficiency of vertical relations relied, however, on LPG chairmen implementing a system of contractual relations regulating the relationship between the various strands of crop and livestock production in accordance with sozialistische Betriebswirtschaft in agriculture. By 1968 very few chairmen had been moved to go so far. ${ }^{7}$ By1969 approximately 60 per cent of LPGs in the Bezirk still had not implemented in full the system of sozialistische Betriebswirtschaft and LPG members had yet to be convinced of the value of vertical cooperation. ${ }^{8}$

The lack of trust in the system of vertical cooperation was unsurprising given the problematic relationship LPGs often had with the food industries. Assessing the situation in 1968 in the experimental KOVs already established in Bezirk Erfurt, the agricultural department of 
the SED Bezirksleitung concluded that the majority of final producers had proved unable to take effective responsibility for the whole chain of cooperation and were found to have resorted to 'outdated working styles', relying too heavily on bureaucratic methods to force LPGs to comply with their demands. ${ }^{9}$ In 1969 it became clear that representatives from final producers still not only did not necessarily have the requisite technical knowledge to make reasonable demands on farmers but also simply did not know enough about their suppliers to influence their development appropriately. ${ }^{10}$

If there were obstacles to LPGs' inclusion in vertical cooperation, the prospects for horizontal cooperation between collective farms to enable specialisation of crop production were also slim. Pressure on KOGs in Kreis Sömmerda to develop specialised crop production in advance of most of the rest of the Bezirk demonstrated the lack of convinced support for the policy among collective farmers or indeed among many LPG brigadiers, board members and even LPG chairmen.

In a number of KOGs in Kreis Sömmerda, the organisation of permanent cooperative crop production had been attempted during May and June 1968. This had proved less than successful, however. LPGs commonly chose not to share their machinery with one another. Few had specialised their crop production or changed their crop rotation or field structure in order to mass-produce, even where they had been given access to the latest machine systems. Despite the arrival of new technology in the form of the E512 combine harvester, the size of fields in even advanced cooperative communities (KOG) such as those based around Weissensee and Mannstedt, Kreis Sömmerda, where the average was below fifteen hectares, still did not allow for the most effective deployment of machinery. ${ }^{11}$

Even in the most advanced KOGs the integrated deployment of machinery had barely been put into practice. Tractor drivers in Schellenburg expressed no desire to take their tractors to work around Sömmerda; LPG members in Tunzenhausen reportedly warned each other against allowing Sömmerda to 'put one over on them'. In the LPG Straussfurt the prospect of specialisation as part of cooperation raised the question of what the rest of the workforce would do. In LPG Grossbrembach there was opposition to cooperation on the grounds that they were doing 'quite well already and saw no reason to give others a boost' ${ }^{12}$ The farmers of successful LPGs were rarely happy to cooperate with their underachieving neighbours. How, the crop production brigadier in Kleinneuhausen wondered in 1968, could he convince his fellow farmers of the benefits of cooperative relations as long as Beichlingen and other LPGs within the KOG continued to have such bad yields? ${ }^{13}$ There 
was little desire among either collective farmers or their functionaries to sacrifice their success for the sake of their neighbours. ${ }^{14}$

Persuading the rank-and-file members of the collective farms of the value to them of a joint crop production unit within their KOG was no small matter. The practical implementation of cooperation required fundamental changes not only to working practices but the whole manner in which farmers perceived their status and identity. As the chairman of the LPG Vehra, Kreis Sömmerda put it:

The step to a common crop production [between LPGs in a KOG] and the development of various cooperative relations is comparable to the step from being a private farmer to being a collective farmer. But back then there was a clear statute which indicated to each person what his rights and obligations were and everyone knew exactly, from their neighbours' experience too, how things proceed and what awaited them. With the common crop production there is still a great deal unclear and we can't give concrete answers to the questions members pose. ${ }^{15}$

Collective farmers were not on the whole willing to agree to the principle of the matter while their pay and conditions in the new system remained uncertain. 'How will pay be measured out fairly - will it be set at the level of the highest paying LPG? Will all the best functionaries work in crop production? How are all the requirements of the plan to be met if we specialise our crop production $?^{\prime 16}$ Even top- and mid-level cadres were reluctant to advocate something without any clear idea how it would affect their future. What status, they wondered, would they have within the new leadership structure in the joint crop production and the LPG? More seriously still, what if any status would the LPG have? If cooperative livestock units were set up alongside the cooperative crop production unit, would the individual LPG cease to exist altogether? ${ }^{17}$

Despite the fact that such questions remained unresolved, the RLN (K) and the SED Kreisleitung in Kreis Sömmerda in particular, but also in neighbouring districts such as Kreis Bad Langensalza and Weimar, ${ }^{18}$ pressed cooperative councils to develop specialised cooperative crop production during the coming year. In accordance with the apparent instructions given at the X German Farmers' Congress and the VII SED Party Congress, LPG chairmen who were anxious to be at the forefront of agricultural development set about arranging crop production in their KOGs independently of the individual LPGs. By February 1969, on paper there had been some success. The RLN (K) claimed to have finally ended any tendencies in the district towards the creation of Groß LPGs out of the full merger of the constituent collective farms in KOGs. It was clear, however, that mid-level cadres - technical advisers and 
heads of the work brigades - in the LPGs remained doubtful of the sense of separating crop production from the LPGs. There were also serious disagreements among leading cadres in a number of cooperative councils which had the potential to scupper harmonious cooperation. ${ }^{19}$

The development of the scale of crop production had gone a long way since the early 1960s. The pressure for even more rapid progress in the latter half of 1968 and 1969 via cooperative crop production, however, came increasingly at the expense of suitable preparation and persuasion of collective farmers. Much of the apparent progress which zealous LPG chairmen and RLN functionaries claimed to have made in organising cooperative crop production had been achieved so rapidly that there were real concerns that in practice it might have an adverse effect on production. Given growing problems in the economy at large as well as unrest in Czechoslovakia, there was arguably good reason to be wary of any measures that might unnecessarily undermine food production within the country.

Whether all this entered into his calculations or not, during the 10th Plenary Session (or Plenum) of the SED Central Committee in April 1969, Walter Ulbricht himself made some damning criticisms of the progress of agricultural transformation which his comments in 1968 had apparently sparked..$^{20}$ The response to Ulbricht's intervention from the GDR's collective farmers revealed a degree of confusion and deception alongside suppressed resentment and conflict throughout LPGs in the Bezirk which thoroughly surprised agricultural functionaries at all levels in the regime hierarchy. Enormous change had been achieved in the past decade; however, the limits and the possibilities of the social transformation of the countryside could now be seen in a truer light. The extent to which agricultural administration at the grass roots was formed by and beholden to the interests and attitudes of collective farmers rather than the malleable object of socialist modernising policy was once again demonstrated.

\section{The Crisis Precipitated}

Ulbricht's intervention was necessary because certain aspects of the party line had, he claimed, been misinterpreted. Crop production was not to become independent of the LPGs, but, as he had said at the X German Farmers' Congress, 'relatively' independent. The food industries were to have a coordinating and directing role over agriculture through the use of mutual contractual relations - not through their dominance of the councils of cooperative unions (KOV). There were thus two lines 
to his criticism of the situation in agriculture: first, the organisation of the cooperative unions had given too much power to administrators in the food industry and undermined the independent status of the LPGs; secondly, a minority of LPGs in advanced states of cooperation had gone too far, too quickly, in the development of independent crop production. Change at such a rate was not suitable for all LPGs and thus these LPGs were no longer to receive publicity as models of the correct path of development.

Central to his comments was the notion of inviolability of the LPG as an economic unit, in which the principles of collective democracy were to be meticulously implemented. If a separate crop production was to exist, it was to be a sub-department of the KOG and its leaders subordinate to the chairmen of the LPGs. Moreover, Ulbricht argued that the development of cooperative relations in crop production must and could only occur gradually in consultation with LPG members. ${ }^{21}$

At a meeting of the RLN of the GDR in May 1969 to evaluate the 10th Plenum, Ulbricht's arguments against the independence of the crop production units were reiterated. ${ }^{22}$ In the ensuing discussion it became clear how widespread divergent conceptions of the imminent development of agricultural organisation had become. At the meeting the influential chairman of the LPG Dahlen described how teachers at a technical college found the essence of the 10th Plenum difficult to grasp, given what they themselves had been told would be the next stage in the GDR's agricultural development. It had been drummed into them thus far, one teacher told him, that in the future, 'of the LPG only the telephone and the desk would be left'; in other words, the establishment of independent cooperative units by the KOG was indeed, as far as they understood the situation, the first step on the road to abandoning the idea of collective property altogether. ${ }^{23}$

There was certainly a tendency in much of the theoretical literature to predict 'the dissolution of the class of the collective farmers' in the near future. Soon farmers would have effectively the same status in society and rights of ownership as a factory worker. In particular, a dominant role for food industries in controlling agricultural production and the transfer of farmland from collective (genossenschaftlich) to cooperative (kooperativ) use seemed to point towards a change in the status of those working in agriculture and the rendering of the LPGs increasingly obsolete. This attitude was not wholly surprising given the continual and deliberate erosion of the proprietary ties between individual farmers and the land they farmed inherent in the reform of LPGs during the 1960s.

Gerhard Grüneberg, speaking to the national RLN, nevertheless now made clear that too much theorising had gone on, particularly as re- 
gards the guiding role of the food industries in conjunction with agriculture. 'There are mountains of books, and one is amazed, when one feels obliged to busy oneself with the matter, by all that has been written about agriculture and the food industry.' His message to the delegates at the conference was that it was not practical for agriculture in general and the LPGs in particular to have their independence compromised. Farmers and not simply administrators were still essential to the effective management of a sector of the economy which remained in many respects subject to uncontrollable (unpredictable and thus unplannable!) natural conditions and would not submit simply to the plans of a bureaucrat, however efficient he might be. ${ }^{24}$

Criticism of recent developments in some LPGs sent shock waves running through the state and party administration concerned with agriculture. To some extent Ulbricht (and in his wake Grüneberg) had in fact done little more than publicly rein in those zealous functionaries who sought to realise the long-term goals of transformation in agriculture ahead of schedule. The essential course of agricultural development was more or less the same as before. Cooperative relations were still to be at the heart of a gradual move towards greater specialisation. The Groß LPG had not been overtly approved as a more effective means of reaching industrial-scale production. The persuasion of LPG members and their subsequent ratification of new measures in accordance with the demands of 'collective democracy' now, as before, was required (at least rhetorically) before progress could be made. Yet it soon became clear that the administration of agriculture from top to bottom was in fact highly sensitive to any suggestion that the steps taken thus far had been in any way mistaken.

In the course of 1968 and 1969 terms such as 'rump LPG' had begun to be used to describe what was left of some LPGs in the Bezirk once allbut-independent joint crop production units had been set up in a few of the KOGs. While the use of this pejorative phrase clearly expressed what was going wrong with the hasty development of cooperative crop production, there had equally clearly been some confidence among LPG functionaries that pursuing the administrative separation of crop production from the LPGs had been officially sanctioned. In some KOGs in Kreis Sömmerda there were reports that LPGs and joint crop production units had separated so much that headed letter paper had been designed and company name signs put up advertising their new status as either a 'Cooperative crop production enterprise' or a 'Livestock production enterprise'. In such cases, where Ulbricht's comments had some clear and direct relevance, i.e. in those few LPGs where intentions to proceed rapidly with developing separate specialised crop and live- 
stock production had already begun to be put into practice, the Kreisleitungen were quick to respond. In the KOG Bachra, Kreis Sömmerda, the development of cooperation in crop production had proceeded so far that the joint crop production was on the verge of proclaiming its independence from its constituent LPGs. The SED Kreisleitung intervened to ensure that the head of the crop production was subordinate to an LPG chairman and responsible to the cooperative council. The chairman of the cooperative council thus could not at the same time be the head of the crop production unit. Furthermore, the joint crop production was to be renamed to identify its subordinate position to the LPGs. It was now to be known as a Cooperative Crop Production Unit, (Kooperative Abteilung Pflanzenproduktion or KAP), emphasising its dependence on the LPGs for its legal status. ${ }^{25}$

Responding directly to the technical criticisms made by Ulbricht was one thing. Dealing with the confusion and rumour which abounded among farmers, LPG functionaries and the state apparatus in the districts was quite another. The variety of responses to Ulbricht's comments in the LPGs and the district party and state administration revealed the complex balance in the relationship between collective farmers, their leading functionaries and the state and party hierarchy. The impossibility of agricultural transformation without some degree of consent from collective farmers themselves, and the often ambiguous role played by LPG functionaries in communicating state authority while protecting personal and local interests, was once again demonstrated.

\section{Crisis and Confusion in Agricultural Administration}

Such were the tensions which had developed in recent years within LPGs, within KOGs and between LPGs and the district authorities that Ulbricht's comments were seized upon as an excuse for attacking all that seemed to be wrong with the status quo in agriculture. What appeared to give farmers and LPG functionaries alike the grounds for their attacks was the emphasis placed upon the independence of the LPG and the importance of consultation as part of collective democracy. Anger and resentment over the lack of consultation with LPG members on policies such as cooperation or the introduction of socialist business economics had reached boiling point. There were thus various strands to the complaints unleashed at the grass roots by the 10th ZK Plenum, not all of which bore an immediate relation to the actual subject of Ulbricht's own criticisms. 
A meeting of the SED Kreisleitung Sömmerda in July 1969 to discuss Ulbricht's concluding remarks heard a report on the reaction of farmers in the district. It was claimed hopefully that the majority of the collective farm members understood correctly that the 10th Plenum did not mean a correction of agricultural policy but rather a continuation of the resolutions of the VII SED Party Congress, with the caveat that this process must not be mismanaged through impatience. In the first days and weeks after the 10th Plenum, however, mid-level LPG cadres were marked out as being particularly problematic, spreading the opinion that 'thanks to the 10th Plenum they could all now take their time and that cooperation would be scaled back'.

More seriously, Ulbricht's remarks were being interpreted as a licence for collective farms to assert their individual independence from outside interference, be it from other LPGs or the state apparatus. One chairman of an LPG was reported to have collected all the newspaper articles he could find on the subject of collective democracy. His intention appears to have been to use them as proof that he could not legitimately implement change without the agreement of his members. ${ }^{26}$

Members of the LPG Lützensömmern in Kreis Bad Langensalza were among the first in Bezirk Erfurt to take the opportunity to voice their frustration and reclaim some independence. The KOR and the RLN (K), they complained, had too often taken decisions affecting the LPG members without any prior discussion of the matter and they had thus been forced to accept what amounted to faits accomplis. ${ }^{27}$ Reports compiled by the DBD in Bezirk Erfurt during May 1969 on the mood in the countryside highlighted the sense among LPG members that recently they had been bullied into things or not listened to sufficiently by functionaries at various levels of agricultural administration, from the LPG board, the KOR, up into the district state administration, and this situation would now have to be rectified. In Kreis Erfurt-Land in particular, DBD members complained about the damage done to the independence of their LPGs because of the pressure put upon them by the RLN $(\mathrm{K}) .^{28}$

Such complaints could be more or less justified in the context of the 10th Plenum. However, doubts over the validity of previous agricultural policy also began to be expressed. LPG members made the point that they had the right to be properly consulted and prepared for cooperation and the separation of crop and livestock production. They also, however, began to suggest that they had a right actively to determine their own path of development. If cooperative relations could only be developed against the will of collective farmers then, the question was 
raised, was it not correct that no such relations exist until farmers were convinced of their value?

In Kreis Arnstadt as well as Kreis Bad Langensalza, collective farmers who in the past had been particularly obstinate in their resistance to cooperation began to draw this conclusion. Where few or no extensive cooperative relations had developed between LPGs, they considered themselves right all along not to have participated in cooperation. Doubts even began to be raised as to whether KOGs could continue to exist at all, if the majority of LPGs opposed them. ${ }^{29}$

Faced with the apparent vindication of collective farmers' hostility to cooperation after the 10th Plenum, LPG functionaries and the staff of the RLN $(\mathrm{K})$ appeared for a time to be at a loss as to how to respond. The chairman of the LPG Kalteneber in Heiligenstadt reportedly expressed his confusion and disillusionment: 'The question which concerns me is whether agricultural policy has changed since the 10th Plenum? There are currently many discussions: cooperation is going to be broken up, or cooperation will lead to the liquidation of the class of the collective farmer. I'm not against new things, but it's not so easy for us up here as it is for those farmers down in the plains. ${ }^{30}$ In Kreis Heiligenstadt, Mühlhausen and Erfurt-Land, staff of the district councils appeared to be uncertain what was going on in the LPG assemblies. ${ }^{31}$ DBD sources noted too that the LPGs were no longer receiving guidance from staff from the SED Kreisleitung or the RLN (K), who themselves no doubt were unclear what the correct path ought to be. In Steinrode, Kreis Worbis some DBD members pointed out that representatives of the district authorities used to participate in every meeting of the cooperative council, but had not turned up once since the 10th Plenum. ${ }^{32}$

Even where the RLN (K)s did attempt to continue to advise the LPGs, however, it was soon clear that concrete decisions about the future of individual KOGs were not possible. Following the 10th Plenum, the RLN (K) in Kreis Sömmerda initially continued to press ahead, encouraging the development of joint crop production in the KOG Kölleda. The economics advisory service attached to the RLN (K) had worked out plans and practices for a joint cooperative crop production in the KOG Kölleda which appeared to be in tune with the 10th Plenum line, as they 'in no way limited the role of the LPGs and foresaw the payment of farmers via the individual collective farms'. There remained, however, a major obstacle to the establishment of a joint cooperative crop production in the KOG: namely the 'current ideological attitude of members'. This the RLN (K) admitted would have to be discussed shortly in 'comprehensive consultation' in the LPGs. ${ }^{33}$ The following month, in a discussion at the district RLN in Kreis Sömmerda, it was reported that 
the fixed attitude of LPG members in a number of collective farms was that cooperation in crop production should be broken up and the LPGs allowed to be independent again. Among these was the LPG 'Neuer Weg' ('New Path') Kölleda. In a letter sent by the chairman and party secretary to the chairman of their KOG, they explained the decision of the LPG's board to withdraw from cooperative crop production. The letter concluded with the chairman and party secretary expressing their regret at this decision having been reached. They pointed out, however, that even they could not get around the words 'the farmers decide'.$^{34}$

By mid-August, the RLN (K) could not help but notice that some KOGs were likely to be hard put to continue even with minor forms of cooperation between LPGs during the harvest. The KOG Mannstedt, it found, was more or less falling apart. In the neighbouring LPGs in Buttstädt, Olbersleben and Essleben, the opinion was widespread, among LPG cadres as well as ordinary farmers, that joint crop production would be broken up and the LPGs allowed to become independent again. It was thus unsurprising that in the KOG Buttstädt even the use of machinery in combination between LPG Essleben and LPG Buttstädt had fallen apart and each LPG had begun to employ its own machinery for its own purposes. All in all, in the words of the SED Kreisleitung, the level of cooperation in this part of the district had 'just about reached zero' ${ }^{35}$ At the August meetings of the SED party organisations in the LPGs in Sömmerda district, the backlash against cooperation continued. In Werningshausen, among other places, the opinion was widespread among LPG members that the deployment of harvesters in cooperation put their LPG at a disadvantage. ${ }^{36}$

Looking back on 1969, a report on the development of cooperation by the SED Bezirksleitung admitted that immediately after the 10th Plenum people no longer worked conscientiously towards realising and fixing cooperative relations'. Among leading cadres in the LPGs as well as in the state apparatus there was insecurity and a 'wait and see' attitude to the further development of cooperation. In sixty-nine out of 150 cooperative communities in the Bezirk a joint unit for crop production had in theory been established. However, given the confusion and conflicts surrounding cooperative production, these KAPs were often not particularly efficient and their inefficiency had only been exacerbated by the poor weather during 1969. Justified dissatisfaction with the whole notion of the KAP among LPG members developed as a result, along with the revived tendency among leading cadres to advocate the Groß LPG as a better alternative. ${ }^{37}$

Now that the need for large-scale production was widely accepted, it seemed to many farmers that the best alternative to cooperation, which 
seemed to solve the conflicts between LPGs and confusion over ownership and distribution of profits and costs between crop and livestock production, was once again the Groß LPG.

The lack of an influential body of advocates of SED agricultural policy promoting the continuation of cooperation in either the KOGs or in individual LPGs clearly increased the chances that alternative ideas would gain widespread support among the general membership. In January and February 1970 a number of reports came in to the SED Bezirksleitung of party organisations whose members claimed to be unable to exert any influence on the boards of the LPGs. In many LPGs, party comrades complained that they were not being sufficiently informed. SED members in Bad Tennstedt remarked: 'Whenever the discussion is about decisive questions, we don't get asked, but rather find out about the decisions made by the board only in the pub later on.' In Ossmanstedt SED members similarly complained: 'Basically we don't get asked at all, if for example some thing needs to be built, that's the board's decision alone. ${ }^{38}$

Where the SED was weak, this was often put down to the existence of a strong alternative party group. DBD members occupying the key functionary positions in particular appeared in a number of cases to be blamed for the failure of SED organisations to have sufficient influence over the direction of individual LPGs' development. Naturally there were many cases in which DBD cadres and party groups in general worked well with SED party members and sought actively to implement current SED policy. The support for the Groß LPG and hostility towards cooperation shown by some DBD members however, raised suspicion in the SED Kreisleitungen. ${ }^{39}$ As a consequence, where cooperative relations had ground to a halt, DBD members in leading positions in the LPGs were suspected, whether fairly or not, of deliberately undermining cooperation while speaking publicly in its favour. ${ }^{40}$

In a meeting with the first secretary of the SED Kreisleitung, Weimar in August 1970, the chairman of the LPG Kromsdorf, himself a member of the DBD, sought to outline some of the basic problems with the development of cooperation since the 10th Plenum in his area. In his analysis, the mood in the collective farms had worsened because the 10th Plenum has not gone out of the minds of the members yet'. At the same time the new organisational structure of the crop production was not conducive to efficient farming. It was proving difficult, for example, for LPG chairmen to have to apply for access to machinery and manpower to a functionary - the head of the crop production unit - who was technically not his superior. The dropping value of the work unit and a cut in the funds available for bonuses had also added to the gen- 
eral dissatisfaction with the new arrangements. The SED Kreisleitung, however, chose to see the problem as essentially one of ideological discipline. Their report concluded: 'it certainly does not overstate the case to make the assertion that cooperative relations above all are hindered by such cadres as do not belong to the SED'. ${ }^{41}$

Whether this assessment was entirely fair or not, in the aftermath of the 10th Plenum, it became clear that the SED regime had failed to close the ideological deficit in the LPGs. The long-term goals of socialist agricultural policy continued to be regarded with suspicion by collective farmers and for the time being the apparatus through which agricultural policy was to be communicated and implemented in the LPGs appeared at best unsure of itself and at worst to have broken down. Amid a worsening economic crisis, the district state authorities appeared unable to give sufficient guidance or practical advice to the LPGs on how they ought to organise themselves. At the same time, LPG chairmen found it impossible to agree with each other on how to proceed with cooperation. Under these circumstances, the possibilities for a coherent programme of future development to be agreed between LPG cadres, LPG members and the district agricultural councils was in most cases remote.

\section{Administrative Gridlock}

After the upheavals resulting from the 10th Plenum, how LPGs of various types, in their various stages of development towards merger and cooperation, could or should proceed to develop their production facilities remained obscure to LPG members and their functionaries. The RLN (K)s, too, appeared to be reticent in dictating a coherent direction to the LPGs given the reassertion of collective democracy and consultation of collective farmers which Ulbricht's comments had provoked. Whether or not cooperation between LPGs, leading to the ultimate separation of crop production from livestock production, ought to be actively pursued for the time being was once again cast into doubt. By the same token, LPG chairmen were not sure whether they ought rather to pursue merger with their neighbours or indeed whether they should seek to remain independent and build up their production facilities individually. ${ }^{42}$

Dealing with these dilemmas was made far more complicated by the atmosphere of uncertainty and fear of financial catastrophe among collective farmers, which resulted from sudden shortages in the supply of essential equipment to LPGs in 1969 and 1970. DBD functionaries in 
Kreis Sömmerda and Kreis Worbis found they could give little satisfactory explanation to collective farmers who could not understand why the supply of essential spare parts for machinery was so much worse than in previous years. ${ }^{43}$

A lower than average yield from the 1969 harvest added to the sense of crisis in some parts of the Bezirk. The whole business of malfunctioning cooperation and specialisation was blamed for aggravating the situation by affecting both the quality and variety of crops produced. Shortages of feed crops in particular strengthened criticism of cooperation in crop production, especially where collective farmers thought that their LPG was receiving less than their fair share, or at least less than was required to sustain their livestock. In some LPGs the downturn in productivity had a serious and immediate effect on working conditions. Just how difficult things had become in some LPGs is evidenced by a noticeable rise in the number of LPG members seeking to withdraw from the collective farms in disillusionment over the poverty in which they worked. ${ }^{44}$

In the course of the harvest in 1969, it had become clear that in those advanced KOGs where separate cooperative crop production had in fact been established, there was often unresolved and disruptive rivalry between the cadres of the LPGs and those of the crop production unit. ${ }^{45}$ By the end of 1969, the cooperative councils of numerous KOGs had simply stopped meeting - existing rather 'only on paper' ${ }^{46}$ During 1970 hostility to cooperative crop production appeared to grow rather than diminish among collective farmers. Members of LPGs harked back to the time prior to the formation of the cooperative crop production, commenting: 'now there is a lot of waste, there is frustration and irritation, instead of progressing, things are going backwards' ${ }^{47}$ By the end of the year LPG chairmen in a number of KOGs were considering whether or not to abandon cooperative relations altogether. ${ }^{48}$ Even where cooperative communities were seemingly up and running, investigation by the RLN (K)s into the extent of cooperative relations revealed the superficiality with which they functioned. ${ }^{49}$

By January 1971, the SED Bezirksleitung estimated that approximately fifty-two of the KOGs in the Bezirk had a cooperative crop production section..$^{50}$ This accounted, however, for less than half the LPGs. For the majority there was still considerable opposition to cooperation. A number of SED Kreisleitungen were still reporting a lack of clarity over the 'meaning in principle and objective necessity of cooperative relations' among LPG members and functionaries. In Kreis Sömmerda LPGs were still considering withdrawing from cooperative communities. ${ }^{51}$ In the KOG Tannroda, Kreis Weimar, the LPG chairmen them- 
selves were thought to be preventing the development of cooperative crop production by simply not taking the steps in practice which they had publicly agreed upon in the cooperative council. The SED Kreisleitung regarded this state of affairs as the result of unwillingness rather than incapability. Allegedly, the discussions of the cooperative council were also notorious among some members of the LPGs for failing to correspond to reality, earning their meetings the nickname 'the fairytale hour'.52

Reports on the mood among collective farmers paint a rather desperate picture, with stagnation in development, problems with production and an apparent inability by either the RLN (K) or the cooperative councils to take action to improve the situation in the individual farms.${ }^{53}$ As a result of the conflicts which cooperation in crop production seemed to cause, there was certainly no consensus in the Bezirk that the separate specialisation of crop and livestock production was indeed the correct way to develop agriculture. During 1971 there were a number of discussions with farmers in the LPGs where cooperative crop production units had been recently established. The same complaints came up repeatedly in nearly all the LPGs in the district where such discussions were held: that the new relationship between crop and livestock was having a negative effect on the quantity and quality of the feed on offer. As a result, both ordinary members and leading cadres of the LPGs began openly to suggest that the 'tearing asunder' of crop and livestock production was mistaken. ${ }^{54}$ Even though LPG cadres were known to have been removed from their posts for actively advocating the Groß LPG as an alternative to the separation of crop and livestock production, there remained considerable uncertainty as to whether such views would not soon be considered acceptable. Until the outcome of the SED's VIII Party Congress was known, LPG chairmen were known to be hesitant to pursue cooperation. ${ }^{55}$

\section{Conclusion}

The last two years of the decade demonstrated more dramatically than ever before the limits of the state apparatus's ability to drive forward transformation and the lack of strong SED influence over farmers. The shifting parameters within which agricultural development had taken place were necessarily shaped by technological advancement and the transformative ideals of socialist ideology. However, they were also clearly shaped by the need for compromise with the personal interests of collective farmers themselves, as they were managed (and misman- 
aged) by the functionaries of the LPGs and the agricultural administration at the grass roots. With the future still uncertain, the failure to deal with the lack of consensus of interests between the SED leadership and LPG members and their functionaries exposed the fragility of what up to then had seemed increasingly stable structures of authority in the districts.

Out of the conflict and confusion arising after the 10th Plenum and the more general economic uncertainty caused by the failure of economic reforms, paradoxically a new relationship began to take shape between the SED leadership and the agricultural workforce. As ever greater restrictions were placed on private production, increasingly well-trained and specialised collective farmers began to accept the necessity of specialising agricultural production and actively supported the development of new and stable structures of agricultural administration at the grass roots. The promise of an end to austerity and a secure future under a more rigorous system of economic planning began too to enable both new and older generations of collective farmers to accept a reconfiguration of the agricultural system.

\section{Notes}

1. ThHStAW Bezirksparteiarchiv der SED Erfurt, Bezirksleitung der SED Erfurt IV/B/2/7-268 SED Bezirksleitung, Abt. Landwirtschaft, Bericht über die LPG in Burgtonna, 29.2.1968, pp. 123-4. The report describes how a members' assembly was held in secret in order that a resolution could be passed against cooperation without interference from the village mayor or the chairman of the LPG Type III.

2. ThHStAW Bezirksparteiarchiv der SED Erfurt, Bezirksleitung der SED Erfurt IV/B/2/7-268 SED Bezirksleitung Abt. Landwirtschaft, Information über Aussprachen im KOV Milch- und Molkereierzeugnisse Mühlhausen, 22-24.9.1968 unter Leitung des Genossen Semisch, Mitglied des ZK der SED, 1.10.1968, p. 79.

3. ThHStAW Bezirksparteiarchiv der SED Erfurt, Bezirksleitung der SED Erfurt IV/B/2/2-022 Protokoll der Bezirksparteiaktivtagung zu den Fragen und Aufgaben der soz. Landwirtschaft am 7.3.1968, Referat Genosse Lüdecke, p. 3.

4. ThHStAW Bezirksparteiarchiv der SED Erfurt, Kreisleitung der SED Sömmerda IV/B/4.10/190 SED Kreisleitungssitzung, Teil Landwirtschaft, 5.6.1968, pp. 12-36.

5. SAPMO BArch DY 30/IV A/1/7/57 ZK der SED Abt. Landwirtschaft, Seminarplan für das Seminar mit den Führungskadern aus der LuN am 13.11.1968 in Liebenwalde.

6. ThHStAW Bezirksparteiarchiv der SED Erfurt, Bezirksleitung der SED Erfurt IV/A/2/3-179 RdB Erfurt, Bericht über den Stand der Konzeption und 
Erprobung einiger Grundsatzfragen zur weiteren Anwendung und Vervollkommnung des NÖSPL ... 19.11.1966, p. 85.

7. SAPMO BArch DY30/IV A 2/2.023/220 Büro Gerhard Grüneberg, Protokoll der Kreisbauernkonferenz Weimar am 18 und 19.4.1968, Referat Gen. Schüffler, Produktionsleiter und Vorsitzender des Kreislandwirtschaftsrat.

8. SAPMO BArch DY60/5000 DBD Bezirksverband Erfurt, Abt. Parteiorgane, Parteiinformation, 27.2.1969.

9. ThHStAW Bezirksparteiarchiv der SED Erfurt, Bezirksleitung der SED Erfurt IV/B/2/7-248/1 SED Bezirksleitung Abt. Landwirtschaft, Entwurf Analyse über die Weiterführung des Experimentes des ÖSS, 30.4.1968, p. 3.

10. SAPMO BArch DY60/5000 DBD Bezirksverband Erfurt, Abt. Parteiorgane, Parteiinformation, 27.2.1969.

11. ThHStAW Bezirksparteiarchiv der SED Erfurt, Kreisleitung der SED Sömmerda IV/B/4.10/190 SED Kreisleitungssitzung, Teil Landwirtschaft, 5.6.1968, p. 20.

12. ThHStAW Bezirksparteiarchiv der SED Erfurt, Bezirksleitung der SED Erfurt IV/B/2/5-161 SED Bezirksleitung Abt. Landwirtschaft, Handmaterial zur Berichterstattung des Sekretariats der SED Kreisleitung Sömmerda ... 7.5.1968, p. 51.

13. ThHStAW Bezirksparteiarchiv der SED Erfurt, Kreisleitung der SED Sömmerda IV/B/4.10/190 SED Kreisleitungssitzung, Teil Landwirtschaft, 5.6.1968, p. 21.

14. ThHStAW Bezirksparteiarchiv der SED Erfurt, Kreisleitung der SED Sömmerda IV/B/4.10/190 SED Kreisleitung Abt. Landwirtschaft, Zu mündlichen Berichten vor dem Sekretariat der Bezirksleitung, 7.5.1968, p. 1.

15. ThHStAW Bezirksparteiarchiv der SED Erfurt, Bezirksleitung der SED Erfurt IV/B/2/7-268 SED Bezirksleitung Abt. Landwirtschaft, Faktenmaterial zu Aktivtagung der KOG Straussfurt am 26.6.1968, p. 47.

16. ThHStAW Bezirksparteiarchiv der SED Erfurt, Kreisleitung der SED Sömmerda IV/B/4.10/101 SED Kreisleitung Abt. Parteiorgane, Einschätzung der MV - Monat November, 29.11.1968, p. 96.

17. ThHStAW Bezirksparteiarchiv der SED Erfurt, Bezirksleitung der SED Erfurt IV/B/2/7-268 SED Bezirksleitung Abt. Landwirtschaft, Faktenmaterial zu Aktivtagung der KOG Straussfurt am 26.6.1968, pp. 42-49.

18. The KOG Berlstedt, Kreis Weimar was among the most advanced in the GDR in developing specialised production through cooperation. As an experimental model for the most efficient means of establishing agriculture on an industrial scale it had an exceptional status within the Bezirk, which enabled it to develop organisationally far in advance of other KOGs.

19. ThHStAW Bezirksparteiarchiv der SED Erfurt, Kreisleitung der SED Sömmerda IV/B/4.10/200 SED Kreisleitung Abt. Landwirtschaft, Perspektiv 10.4.1969, p. 137.

20. SAPMO BArch DY30/IV 2/1/395 Tagungen des ZK der SED - 10. Plenum des ZK, 24.4.1969, Schlusswort des Genossen Ulbricht, pp. 211-21.

21. The cooperation based around Berlstedt, Kreis Weimar had for many years been a model of advanced socialist agricultural policy. However, in the context of the 10th Plenum in 1969, Walter Ulbricht made it clear that Berlstedt 
was no longer an example which should be followed. Although not wholly critical of the developments made by the LPGs in the KOG Berlstedt, the overall direction was no longer to be publicised, particularly as regards specialisation. SAPMO BArch DY30/IV 2/1/395 Tagungen des ZK der SED 10. Plenum des ZK, 24.4.1969, Schlusswort des Genossen Ulbricht, p. 214f.

22. SAPMO BArch DY30/IV A 2/2.2023/169 Büro Gerhard Grüneberg, RLN der DDR - 6. Tagung am 16.5.1969, Beitrag des Ministers Georg Ewald.

23. SAPMO BArch DY30/IV A 2/2.2023/169 Büro Gerhard Grüneberg, RLN der DDR - 6. Tagung am 16.5.1969, Beitrag des Genossen Döhler, Vorsitzender der LPG Dahlen.

24. SAPMO BArch DY30/IV A 2/2.2023/169 Büro Gerhard Grüneberg RLN der DDR - 6. Tagung am 16.5.1969, Beitrag des Genossen Grüneberg.

25. ThHStAW Bezirksparteiarchiv der SED Erfurt, Kreisleitung der SED Sömmerda IV/B/4.10/200 SED Kreisleitung, Abt. Landwirtschaft, Probleme der Kooperation - Beschluss Politbüro vom 25.7.1969, pp. 150-9.

26. ThHStAW Bezirksparteiarchiv der SED Erfurt, Kreisleitung der SED IV/ B/4.10/190 SED Kreisleitung Sömmerda, Abt. Landwirtschaft, Kreisleitungssitzung, 3.7.1969, pp. 136-55.

27. ThHStAW Bezirksparteiarchiv der SED Erfurt, Bezirksleitung der SED Erfurt IV/B/2/5-183 SED Bezirksleitung, Abt. Parteiorgane, Kurzinformation, Stimmen von Genossenschaftsbäuerinnen und -bauern zum Schlusswort des Genossen Walter Ulbricht auf der 10. Tagung des ZK zum Problem der soz. Landwirtschaft, 21.5.1969, p. 326.

28. ThHStAW Bezirksparteiarchiv der SED Erfurt, Bezirksleitung der SED Erfurt IV/B/2/5-410 DBD Bezirksverband, Bericht an den 1. Sekretär der Bezirksleitung der SED, 23.5.1969, pp. 174-80.

29. ThHStAW Bezirksparteiarchiv der SED Erfurt, Bezirksleitung der SED Erfurt IV/B/2/5-183 SED Bezirksleitung, Abt. Parteiorgane, Kurzinformation, Stimmen von Genossenschaftsbäuerinnen und -bauern zum Schlusswort des Genossen Walter Ulbricht auf der 10. Tagung des ZK zum Problem der soz. Landwirtschaft, 21.5.1969, p. 327.

30. ThHStAW Bezirksparteiarchiv der SED Erfurt, Bezirksleitung der SED Erfurt IV/B/2/5-183 SED Bezirksleitung Abt. Parteiorgane, Kurzinformation, Stimmen von Genossenschaftsbäuerinnen und -bauern ... 21.5.1969, p. 326.

31. ThHStAW Bezirksparteiarchiv der SED Erfurt, Bezirksleitung der SED Erfurt IV/B/2/5-183 SED Bezirksleitung Abt. Parteiorgane, Kurzinformation über den Stand der Durchführung ... 17.7.1969, p. 392.

32. ThHStAW Bezirksparteiarchiv der SED Erfurt, Bezirksleitung der SED Erfurt IV/B/2/5-410 DBD Bezirksverband, Auswertung der Berichte der Kreisverbände über Meinungen unserer Mitglieder zum 10. Plenum des ZK der SED und unserer 5. Parteivorstandssitzung (undated), pp. 181-6.

33. ThHStAW Bezirksparteiarchiv der SED Erfurt, Kreisleitung der SED Sömmerda IV/B/4.10/200 RLN Sömmerda, Produktionsleitung an die SED Kreisleitung, über KOG Kölleda, 17.7.1969, p. 139.

34. ThHStAW Bezirksparteiarchiv der SED Erfurt, Kreisleitung der SED IV/ B/4.10/200 Vorsitzender und Parteisekretär der LPG 'Neuer Weg' Kölleda an den Vorsitzenden der KOG Kölleda, 28.8.1969, p. 163. 
35. ThHStAW Bezirksparteiarchiv der SED Erfurt, Kreisleitung der SED Sömmerda IV/B/4.10/200 Information über Beratung der Produktionsleitung des RLN (K) am 14.8.1969, pp. 160-2.

36. ThHStAW Bezirksparteiarchiv der SED Erfurt, Kreisleitung der SED Sömmerda IV/B/4.10/101 SED Kreisleitung Abt. Parteiorgane, Bericht über die im August stattgefundenen Parteiversammlungen, p. 137.

37. ThHStAW Bezirksparteiarchiv der SED Erfurt, Bezirksleitung der SED Erfurt IV/B/2/7-267 SED Bezirksleitung Abt. Landwirtschaft Information über den Stand der Entwicklung der Kooperationsbeziehungen im Bezirk Erfurt und die sich daraus ergebenden Schlussfolgerungen ... 19.1.1970, pp. 79-95.

38. ThHStAW Bezirksparteiarchiv der SED Erfurt, Bezirksleitung der SED Erfurt IV/B/2/5-165 SED Bezirksleitung Sektor Operativ, Faktenmaterial über einige Probleme der Parteiarbeit in der Landwirtschaft und Nahrungsgüterwirtschaft, Jan. 1970, p. 392; IV/B/2/9.01-289 SED Bezirksleitung Abt. Parteiorgane, Bericht über eine Aussprache mit einer Parteigruppe der BPO der SED der LPG 'Rotes Banner' Körner, Krs. Mühlhausen, 3.12.1969, p. 226; SED Bezirksleitung, Abt. Parteiorgane Protokoll über die Gruppenaussprache mit Genossen in der LPG Bad Tennstedt am 3.12.1969, 4.12.1969, p. 240.; Information über die am 3.12.1969 in der PO der LPG Type III, Willerstedt, Krs. Apolda, durchgeführte Aussprache, 5.12.1969, p. 255.

39. ThHStAW Bezirksparteiarchiv der SED Erfurt, Bezirksleitung der SED Erfurt IV/B/2/5-165 SED Bezirksleitung Sektor Operativ, Faktenmaterial über einige Probleme der Parteiarbeit in der Landwirtschaft und Nahrungsgüterwirtschaft, Jan. 1970, p. 392; SAPMO BArch DY60/2973 DBD Bezirksvorstand, Abt. Parteiorgane, Neuwahlabschlussbericht, 21.1.1970.

40. SAPMO BArch DY60/2973 DBD Parteivorstand, Abt. Parteiorgane, Wertung des Weiteren Verlaufs der Diskussionen zur Vorebreitung des Perspektivplanes; DBD Bezirksverband, Parteiiformation, 11.8.1970; DBD Bezirksverband, Abt. Parteiorgane, Neuwahlbeschlussbericht, 21.1.1970; ThHStAW Bezirksparteiarchiv der SED Erfurt, Kreisleitung der SED Sömmerda IV/ B/4.10/198 SED Kreisleitung, Abt. Landwirtschaft, Kreisbauernkonferenz am 4. und 5.3.1970, Diskussionsbeitrag K. Schwarz, LPG Mannstedt, pp. 157-65; IV/B/2/5-165 SED Bezirksleitung Abt. Parteiorgane Erste Einschätzungen der Kreisleitungssitzungen zur Auswertung der 14. Tagung des ZK, 19.1.1971, pp. 568-74.

41. ThHStAW Bezirksparteiarchiv der SED Erfurt, Bezirksleitung der SED Erfurt IV/B/2/7-268 SED Kreisleitung Weimar, Bericht an Genossen Lüdecke, Abt. Landwirtschaft der Bezirksleitung, 12.10.1970, pp. 371-5.

42. SAPMO BArch DY60/2973 DBD Bezirksvorstand, Abt. Parteiorgane, Wertung des weiteren Verlaufs der Diskussionen zur Vorbereitung des Perspektivplanes, 21.9.1970.

43. SAPMO BArch DY60/2973 DBD Kreisverband Worbis, Abt. Parteiorgane, Parteiinformation, 16.2.1970; DBD Kreisverband Sömmerda, Abt. Parteiorgane, Information über die Arbeit unserer Partei in der Wahlvorbereitung, 9.2.1970.

44. ThHStAW Bezirksparteiarchiv der SED Erfurt, Kreisleitung der SED Söm- 
merda IV/B/4.10/101 SED Kreisleitung, Abt. Parteiorgane, Einschätzung der MV - Monat Januar, 4.2.1970, p. 194.

45. ThHStAW Bezirksparteiarchiv der SED Erfurt, Kreisleitung der SED Sömmerda IV/B/4.10/070 SED Kreisleitung Abt. Landwirtschaft, Protokoll über den Schrittmacherberatung am 11.9.1969 in der SED Kreisleitung, 12.9.1969, pp. 3-6.

46. ThHStAW Bezirksparteiarchiv der SED Erfurt, Bezirksleitung der SED Erfurt IV/B/2/5-410 DBD Bezirksverband, Zu einigen Entwicklungsproblemen der sozialistischen Landwirtschaft im Bezirk Erfurt, 12.11.1969, pp. 197-208.

47. ThHStAW Bezirksparteiarchiv der SED Erfurt, Bezirksleitung der SED Erfurt IV/2/9.01-287 SED Bezirksleitung Abt. Landwirtschaft, Protokoll der Gruppenaussprache in der LPG Alterstedt, 16.11.1970, p. 292; Protokoll der Gruppenaussprache mit Genossenschaftsmitgliedern der LPG Typ III Weberstedt, 29.10.1970, p .295; Informationsbericht über die am 29.10.1970 in der LPG Schönstedt, Kr. Bad Langensalza, durchgeführte Gruppenaussprache, 2.11.1970, p. 309.

48. ThHStAW Bezirksparteiarchiv der SED Erfurt, Bezirksleitung der SED Erfurt IV/B/2/7-267 SED Bezirksleitung Abt. Landwirtschaft, Stellungnahme zur Information der Produktionsleitung des RLN (B) ... 11.12.1970, p. 239.

49. ThHStAW RdB L14600 RLN (B), Probleme bei Durchsetzung der sozialistischen Demokratie und Durchführung des Wettbewerbes in den LPG und KOG im Bezirk Erfurt im 1970 (undated).

50. ThHStAW Bezirksparteiarchiv der SED Erfurt, Bezirksleitung der SED Erfurt IV/B/2/7-267 SED Bezirksleitung, Abt. Landwirtschaft Einschätzung der Entwicklung der gemeinsamen Abteilungen Pflanzenproduktion auf der Grundlage der von Rücksprachen mit den SED Kreisleitungen am 19.1.1971, p. 214.

51. ThHStAW Bezirksparteiarchiv der SED Erfurt, Bezirksleitung der SED Erfurt IV/B/2/5-165 SED Bezirksleitung Abt. Parteiorgane, Erste Einschätzungen der Kreisleitungssitzungen zur Auswertung der 14. Tagung des ZK, 19.1.1971, p. 568.

52. 'Fairytale hour' here translates the German 'Märchenstunde': ThHStAW Bezirksparteiarchiv der SED Erfurt, Bezirksleitung der SED Erfurt IV/ B/2/7-268 SED Bezirksleitung Abt. Landwirtschaft, Information über Aussprachen in der KOG Tannroda, Kreis Weimar, 8.3.1971.

53. KA Sömmerda (KAS) 264, RdK Sömmerda, Untersuchung der 4. Arbeitsgruppe zur Vorbereitung der Kreisdelegiertenkonferenz der SED in Sömmerda, 1.3.1971.

54. ThHStAW Bezirksparteiarchiv der SED Erfurt, Kreisleitung der SED Sömmerda IV/B/4.10/149 SED Kreisleitung Abt. Landwirtschaft, Aussprache in der LPG 'Rotes Banner' Büchel, 7.4.1971, p. 83; RLN (K), Aussprache in der Milchproduktion in einem Kollektiv der Milchviehhaltung der LPG Beichlingen, 22.4.1971, p. 86.

55. ThHStAW Bezirksparteiarchiv der SED Erfurt, Bezirksleitung der SED Erfurt IV/B/2/7-268 SED Bezirksleitung Abt. Landwirtschaft, Information über Kooperationen des Kreises Weimar (Auftrag des Genossen Lüdecke), 30.8.1971. 
PART III fo

\section{STABLE INSTABILITY: \\ ECONOMIC STAGNATION AND THE END OF TRANSFORMATION}




\title{
of 7
}

\section{From Ulbricht to HoNeCKER}

\begin{abstract}
All new things have to get properly settled in ... there is agreement with the social development as a whole, but it must be organised properly. Then we'll get something out of it ... We don't want to earn less. ${ }^{1}$

(Opinions of LPG members in Stotternheim showing their tentative acceptance of plans for the formation of the KAP.)
\end{abstract}

The explicit transfer of power at the top of the SED hierarchy from Walter Ulbricht to Erich Honecker in 1971 sealed a shift in the approach of the SED leadership towards the management of the economy. Austerity and economic reform in the pursuit of utopian goals of social and economic transformation were, broadly speaking, abandoned in order to overcome a deficit of popular support for the SED regime. In its stead a form of consumer socialism was established which sought to satisfy the material needs of the population, though with little consideration for the longer-term costs to the state's economic viability. The transfer of power from Ulbricht to Honecker was thus an important turning point.

Measures to improve living and working conditions in rural communities, along with increased investment in agriculture, engendered greater confidence in the possibilities for financial security under a transformed system of agricultural organisation. The gradual return of coherence to the state administration's approach to agriculture, renewed efforts by the SED to assert its influence over the LPGs themselves and the final restriction on private production with the demise of the Type I LPGs were vital in subduing any lingering opposition to the transformation of agriculture through cooperation. The stabilisation of the structures through which SED policies were communicated to and the manner in which they were received by collective farmers during the 1970s, however, must also be seen in the context of the conflicts and accommodations made between farmers, LPG chairmen and the functionaries of the district state and party apparatus during the previous decade. 


\section{The Dynamic 1960s? The Limitations of Life in East German Agriculture}

The 1960s have been regarded as the dynamic years of the GDR's development. ${ }^{2}$ The security lent the SED leadership by the erection of the Wall at the start of the decade allowed Ulbricht to lead the GDR down a path of radical social transformation and attempted economic reform. They were certainly challenging and exciting years for those who sought to push forward the transformation of the scale and organisation of agricultural production and with it the social fabric of rural society. The gradual professionalisation of the agricultural workforce through increased levels of qualification, the provision of more advanced machinery to the LPGs and the increased scale of crop production and to a lesser extent livestock production under the auspices of the relatively independent district agricultural councils were elements of, what was for some, a positive transformation of agriculture since collectivisation. The consolidation of the LPGs and their stabilisation as independent financial institutions arguably brought a degree of harmony and prosperity to some rural communities relative to the period directly after the completion of full collectivisation. ${ }^{3}$ The 1960s and early 1970s have been said by some former collective farmers with hindsight to have been 'the best years' in the GDR. ${ }^{4}$

As we have seen, however, collective farmers of all types, but especially in the LPG Type I, were by no means convinced of the benefits of this process of socialist modernisation thus far. Moreover, in terms of living and working conditions in rural communities, there was much less cause for contentment: agricultural transformation did not bring with it comprehensive or consistent improvement to working conditions around the Bezirk, while Ulbricht's wider economic reforms came at the price of a degree of austerity which few in rural communities were ultimately willing to pay.

In the early 1960s, in the first years after the completion of collectivisation, the villages of Bezirk Erfurt were by no means idyllic. The amount of labour required by collective farmers in all sorts of LPGs was back-breaking and rendered doubly hard by difficult weather conditions and a relative lack of resources of building materials and machinery, fertiliser and good-quality seed, to name but a few shortages. Villages were unconnected to a central water supply, while the quality of the road network and access to public transport left many communities in relative isolation. Access to the latest consumer products and labour-saving devices was very limited given the problems of delivery and the size of the local village shop, while the possibilities for enter- 
tainment centred almost exclusively on the local village pub. ${ }^{5}$ Improving housing also proved to be a serious problem in rural communities, as it was in urban centres. Much of the housing in the villages was over a hundred years old and though not so ravaged by war bombardment was in a poor state of repair. There was thus considerable room for improvement. ${ }^{6}$

There is no doubt that by the late 1960s some modern conveniences had become available to villagers in line with the GDR's industrial development during the decade. ${ }^{7}$ Furthermore the LPGs - particularly where they were the largest local employer - had started playing an active role in organising and funding the construction of better communal facilities and improving housing. ${ }^{8}$ Very often for the least well-off the LPG represented something of a liberation; there was much to be said for the regular payment of wages, a regulated working day, subsidised kitchens and even the opportunity for holidays.

There is no doubt, too, that many in the 1960s benefited from the social change associated with collectivisation. Greater access to higher education opened channels for new career opportunities and some social mobility. Landless farm labourers were able to achieve new status in the LPGs, while women and young people were to some extent granted greater independence as their traditional obligations to the farm and to the household were reconfigured following collectivisation. Moreover, the bureaucracy and welfare infrastructure that accompanied the expansion of LPGs made a range of new - not strictly agricultural - jobs available in the countryside. ${ }^{9}$ This enabled women to take up positions of not inconsiderable authority and responsibility in a range of roles from the LPG canteens to the LPG bureaucracy. ${ }^{10}$ The potentially powerful position of chief accountant was increasingly occupied by women in LPGs during the 1960s and 1970s. Within the farm itself, there is evidence into the 1970s of women farmers being barred from participation in decision making and discouraged from gaining qualifications while male farmers continued to occupy most of the responsible jobs within the LPG up to 1989. Nevertheless, an increasing proportion of women were able to participate in the LPG boards, become brigade leaders or, in a very few cases, heads of the LPG. For this, among other reasons, village women interviewed after the Wende continued to acclaim the benefits of the collective model. The experience of community, the chance to gain recognition of personal achievement, greater free time and less rigid social control in the village were considered of particular value. ${ }^{11}$

Nonetheless, in most rural communities by the end of the 1960s, the degree of improvement in living standards and working conditions in 
general terms had by no means been consistently dramatic. ${ }^{12}$ The process of separating out and then concentrating crop and livestock production as well as other essential elements of agricultural production (machine repair, building, fertiliser and chemical storage) over a wider area encouraged (indeed required) the centralisation of the facilities for agricultural production and administration in single central villages. These in turn attracted investment in housing and other amenities to certain areas, beginning in some respects to fulfil the SED's proclaimed intention of matching rural with urban living conditions. However, this process left a large number of smaller but by no means obsolescent communities with little prospect of future improvement or even the maintenance of their local services. Some villages were beginning to undergo a process of depopulation, losing their status both as settlements and as centres of production. The proportion of people required to work in agriculture was declining steadily during the 1960s owing to technological development. At the same time, many young men were leaving the villages thanks to the introduction of military service in 1962, and the prospect on completion of this service of further education and training and access to better jobs in industry.

On the whole, however, the disparity was most clear to villagers themselves in the extent to which living standards in rural communities had failed to improve in comparison to those in towns over the decade.

The quid pro quo of collectivisation and subsequent steps to transform the organisation of agriculture - restricting private production and local independence - had always been the improvement to living and working conditions in rural communities which social and economic transformation would bring. By the end of the 1960s, however, a large proportion of those who remained in the agricultural workforce could see no real improvement in the living standard available to them, especially when compared with the conditions for those who worked in industry and lived in towns. Although the incomes of farmers had improved since the early 1960s, there was a consistent sense that they were being underpaid for the amount of time and effort they put in. A comparison with working conditions in industry had long been a problem for those functionaries at the grass roots attempting to quell dissatisfaction among collective farmers and persuade young people to remain in agriculture. Concessions to consumerism and immediate improvements to working conditions across the economy, which were introduced under Walter Ulbricht and considerably extended under Erich Honecker, served often only to highlight the lesser status of agricultural production in this respect. 
In 1967 the Secretary for Agitation and Propaganda in the SED Kreisleitung Sömmerda wrote of the damage done to popular opinion of the SED regime by the lack of improvement to working and living conditions. In particular he singled out the consistent complaint among farmers that improvements to working conditions (such as the five-day week) promised by the VII SED Party Congress did not appear to include them, especially if they were tending livestock. ${ }^{13}$ Discussion of how in practice to introduce the five-day week had been under consideration by the agricultural council for some time. In response to a request from the chairman of the Rat des Bezirkes for information on how it might be introduced in agriculture at the end of 1965, the head of the Bezirk agricultural council was forced to point out essential problems that prevented the five-day week from being applied to the LPGs. As things stood it was still difficult to find the personnel to give livestock farmers a regular six-day week let alone anything less. Furthermore, with the seasonal variation in agricultural work, five-day weeks could only be arranged around the peak working periods. ${ }^{14}$ The introduction of the fortnightly five-day week elsewhere in the economy provoked complaints during end-of-year assemblies held in the LPG in Kreis Arnstadt in January 1966 that agriculture 'never gets taken into account when it comes to such social improvements'.$^{15}$

During discussion of the new constitution in 1968, the continuing disgruntlement over their living standards and working conditions was made clear by farmers. The commitment in Article 30 of the constitution to provide employment for everyone and allow everyone the freedom to choose their employment - albeit according to the requirements of the economy - sparked new hopes among some farmers that they might be able to abandon their membership of the LPG more easily and take up better-paid work in industry. Article 31 of the constitution, which guaranteed a right to free time and relaxation to all, provoked some cynicism from LPG members who compared the conditions for those working in industry with the long hours and numerous handicaps faced by farmers in the GDR. ${ }^{16}$ Although there had been considerable increases in the amount of machinery available to farmers which alleviated some of the more laborious tasks in agriculture, suitable machinery was not always available or reliable. Root crops in particular continued in many LPGs to be harvested by hand. Moreover those, usually men, who worked with the machinery sustained in large numbers severe physical injury and strain from the new conditions in which they worked. Less manpower may have been necessary thanks to the new technology but not always less individual physical effort from the machine operator. 
For those, very often women, who worked with livestock, conditions were reported to be especially hard. Working hours were very long and there was little scope for days off, given the shortage of those free to deputise. At the same time, the concentration on improving crop production had forced LPGs on the whole not to invest properly in the construction of new buildings in which to house animals or in the machinery to alleviate the most labour-intensive tasks of tending the stock. The lack of mechanisation in the sheds to deal with the provision of feed and the removal of dung gave the lie to promises of better conditions in the near future. As one woman farmer pointed out at a meeting of women farmers in the Erfurt-Land district in June 1963:

a lot is said about new technology but in livestock we work like we did in our great grandfather's time. Especially the mucking out and the fodder transport is so difficult that many women don't want to work in the sheds. And when we ask the men to help us with the heavy work, they'd rather do it all themselves. The newly built animal sheds are often so primitive and so far away from the village. It doesn't help us to make the work easier or to enjoy it either. ${ }^{17}$

By the late 1960s improvement had often not been forthcoming.

How seriously the conditions for livestock production had been neglected in LPGs in Bezirk Erfurt at the end of the decade is revealed in a report by the veterinary department at the RLN (B) in 1971 which noted seriously high levels of livestock mortality. In most cases the causes of the unnaturally high number of deaths of animals could be traced directly to the conditions in which they were being kept. An investigation found that in approximately one in seven LPGs and one in three VEGs 'unbearable' conditions - in most cases, overcrowding, damp, cold and lack of ventilation in livestock sheds - had caused heavy losses in both old and new livestock sheds. Old buildings were often found to be primitive and not properly suited to the uses being made of them, particularly in terms of the quantities of animals housed in them. Meanwhile, new buildings were found to have been left unfinished or shoddily constructed owing to a lack of materials or insufficient funds to pay for them. The conditions in which cattle were kept in a number of LPGs were described as particularly vile. In thirteen LPGs it was noted that the holdings were vastly overcrowded, resulting in the laming and suffocation of animals, and in nine LPGs a basic lack of sufficient feed had caused animals to die of starvation. Elsewhere large numbers of cows, bullocks and calves were kept in several small sheds, which had no efficient means of disposing of the quantities of muck and slurry produced. Consequently this lay thick on the ground and had contaminated much of the rest of the farm, greatly enhancing the risk of disease 
as well as creating an unbearable climate in the sheds. ${ }^{18}$ As well as being terrible for the animals, these were clearly grim places to work.

The problem of livestock production was in large part down to the limitations placed on the LPGs during the 1960s for the sake of the ideal transition to industrial-scale farming in the future. Little investment had been allowed in the development of new facilities until it was clear how this could be done on a scale and with a degree of specialisation that allowed the most rational use of resources and provided the greatest level of productivity possible. In the meantime, the numbers of livestock had still to be maintained in order to ensure proper use could be made of the facilities once they were built. In a number of Type I and II LPGs, where the average age of the members was now close or beyond retirement age and where it had not been possible to alleviate some of the burdens of private livestock production because of the lack of space in collective buildings, LPG members were beginning to despair of the future. ${ }^{19}$ In one LPG Type I, the members commented on the impossibility of their situation: 'in the immediate future we're not allowed to build and we're not allowed to merge with an LPG Type III ...', they complained, 'where and how are we supposed to contain the livestock production from old people's farms?'20 The abandonment of the dual price for produce from livestock in 1969 placed the LPG Type I on an equal footing with LPG Type III, making it necessary to introduce new measures to control the reinvestment of profits in developing industrialscale agriculture. Given the straitened economic circumstances in the GDR as a whole and the ongoing conflicts within agriculture itself, however, it is not surprising that they were not universally welcomed. ${ }^{21}$

During 1970 new regulations were announced to establish in LPGs greater controls over the balance between consumption of profits in pay and bonuses and accumulation for investment. ${ }^{22}$ The RLN (K) and the State Bank for Agriculture and the Food Industry were given greater powers to encourage cooperative investment and to force LPGs, particularly the few remaining Type I LPGs, to fund the formation of industrial-scale production facilities. The financial burden met with a negative response from farmers, particularly in those districts where Type I LPGs still existed in large numbers. A number of chairmen in Kreis Sondershausen suggested that the new system punished farmers for having been successful. ${ }^{23}$ In particular in Heiligenstadt there was a general feeling among Type I members that: 'we're are being scrubbed dry by the state - now they want to take every last thing away from us $^{\prime} .{ }^{24}$ In a report by the DBD in Heiligenstadt in July 1970 the new economic regulations were considered by some even to spell the end of the existence of the collective farmer: 'now they'll pull the rope taut for 
us' $^{25}$ Similar responses such as 'now they even want our trousers' or 'there's no point in working' were found in other districts in relation to the new restrictive regulations on pay, bonuses and social security contributions in the LPGs. ${ }^{26}$ Such moves to restrict pay for those working in agriculture seemed merely to add insult to injury given that it seemed to many farmers that they had never before been so badly supplied. ${ }^{27}$

When the economy seized up and bottlenecks in supply throughout industry and agriculture began to occur towards the end of 1969 and during 1970, collective farmers and villagers in general felt themselves to be bearing the brunt of the shortages that arose. Bottlenecks in industry had begun to compromise the supply of consumer goods to the population, particularly in rural areas which were always hit worst by a breakdown in distribution and supply. ${ }^{28} \mathrm{~A}$ report on the situation in 1970 by the SED Kreisleitung Sömmerda put the blame for the country's economic problems on the inadequacy with which complex economic reforms had been implemented and the failure of the party to communicate effectively with the people. Lack of decent housing, shortages of goods available and lack of plan fulfilment all backed up general public scepticism with regard to the SED's claims of socialism's superiority and a sense of resignation that 'things will not improve'. What confidence there was in the SED regime to provide stability and security as well as economic and social improvement was badly undermined. ${ }^{29}$

\section{The Failure of Economic Reform}

In the run-up to the VIII SED Congress in 1971 criticism of the manner of implementation of SED agricultural policy began to mount. Although no direct attacks were made on Ulbricht's decisions with regard to industrialising production, it was clear that agriculture had suffered from the failure of his economic reforms. LPGs were being forced, it seemed, to carry the burden of the difficulties of other sectors of the economy. As a result of price reform in industry, the cost of materials and equipment purchased by the LPGs had risen considerably. A vastly higher proportion of LPGs' profits was thus being spent on equipment - which was not always of good quality - while farmers were being compelled to cap their incomes. ${ }^{30}$ Particularly at a time of organisational transition for LPGs, the inability to work out a plan for their future development which was based on secure supply of tools, machinery, fertiliser and building materials was clearly a serious problem with far-reaching consequences.

Discussions on plan fulfilment reported on by the DBD Kreisverband in Kreis Gotha revealed the degree of irritation growing amongst farm- 
ers. Exhortations to farmers to be more efficient must have been like a red rag to a bull. One farmer reportedly commented: 'You lot talk about clever leadership, and yet there are no spare parts here for the machines, no tyres for the trailers - everywhere you look something is missing. Give it a rest with the leadership and the planning. ${ }^{31}$ If this system of economic administration was to continue, farmers suggested, then the LPGs must be allowed to employ lawyers for themselves so as to advocate their interests against industrial enterprises, which had failed in recent years to keep their contractual obligations. The failure with little or no notice to supply spare parts for machinery, fertiliser, disinfectant, veterinary equipment and protective work clothing had all contributed to poorer working conditions and lower production levels in agriculture, for which farmers now sought redress. ${ }^{32}$ The head of crop production in Griesheim made his expectations no less clear in June 1971: 'We expect that as a consequence of the VIII SED Party Congress, all the relevant sections of the economy will give us better support, especially those who produce agricultural machinery. One can't get rid of the feeling that in several places citizens are sitting around actually doing the work of the enemy and getting away with things by coming up with all sorts of excuses. ${ }^{\prime 33}$

Concerns over the manner in which agriculture was being treated was not just an issue for the collective farmers and LPG functionaries but also resonated throughout the agricultural administration of party and state. It was certainly not the intention of leading SED functionaries responsible for agriculture to see productivity in agriculture reduced. They were well aware that low morale among collective farmers, sustained by difficult working and living conditions, was not conducive to the successful development of agricultural production. It was even clearer to leading agricultural functionaries in Berlin that agriculture was in danger of being made the financial scapegoat for difficulties in industry or construction. As a result, Gerhard Grüneberg was active in lobbying for agriculture to be given greater protection from increases in the prices for industrial products and for greater recognition to be given to the achievements of agriculture since collectivisation.

Fluctuating prices as a result of the latest economic reforms had caused administrative grief and hampered cost control across East German agriculture. Inflation in prices for construction materials and the exorbitant prices charged for new machinery acted as natural disincentives for the development of industrial-scale agriculture. ${ }^{34}$ The major departure established by VIII SED Party Congress was thus the reorganisation of the economy along more conservative lines. A degree of central control and more extensive centrally defined plans replaced the 
complex systems of economic planning and incentive established by the various reforms of the Ulbricht era.

\section{Continuities}

With the VIII SED Party Congress in 1971, which marked the effective transition of power from Ulbricht to Erich Honecker within the SED leadership, there was little immediate change in socialist agricultural policy. The gradual development of ever more comprehensive cooperation in crop production was still at the heart of the plans for reaching the next stage in agriculture and rural society's social and economic development. The confirmation of the party line, despite the apparent transfer of power, however, did remove much of the remaining reticence in the hierarchy of both party and state in their attempts to implement policy. The paralysis of the previous year and a half was to some extent relieved by the clear official sanction given at the VIII SED Party Congress to the continuation of cooperative crop production. The path and pace of development continued nevertheless to vary considerably from LPG to LPG. There was certainly neither sudden uniform enthusiasm nor a centrally driven mass agitation campaign for cooperation or for the separation of crop and livestock production.

A modus vivendi between farmers, the leading cadres in the LPGs and the district functionaries of party and state could not be established everywhere with ease. The same arguments still remained pertinent to local protagonists disputing the value of cooperative relations with one another. There was thus considerable continuity in the immediate experience of farmers and LPG functionaries on the ground. Despite the apparent significance of Ulbricht's loss in authority within the SED hierarchy, the continuing presence of Gerhard Grüneberg as the leading force in the Politburo on agricultural matters ensured that the vision guiding the ultimate social and economic transformation of agriculture in the GDR remained as before. After the uncertainty of the last years of Ulbricht's period in office, there is no doubt that a degree of initiative and dynamism returned to socialist agriculture, though the impact was neither immediate nor universal.

In September 1971, there was general acclamation in the party meetings of the LPG BPOs in Bezirk Erfurt of the decision made to supply the LPGs with extra sources of fodder to balance out the problems caused by recent difficult weather. ${ }^{35}$ This was a much-needed measure and brought relief to several LPGs facing another difficult year feeding their livestock. It also took the pressure off the existing coopera- 
tive crop production units to be immediately very efficient in exceeding their plan targets. However, Honecker could not claim the plaudits for a general improvement in living conditions in rural communities. In Bezirk Erfurt, difficulties with the potato harvest saw a public relations disaster for the regime in general and in particular for state functionaries in several rural communities. The need to reclaim potatoes from the cellars of LPG members in order to ensure there were sufficient numbers available in the shops brought with it some lasting bad blood. As a representative of the trade organisation in Leubingen pointed out in September 1972: 'We all remember all too well, what a political outcome the reclamations from the population had last year. Quite apart from the effort which we and the affected farms had with loading and unloading, we can't allow ourselves another such dilemma again. ${ }^{36}$

The continuing lack of a sufficient supply of inorganic fertiliser in the Bezirk caused some farmers to voice the suspicion even that 'economic sabotage' was being committed. The response to the extra grain that was distributed to the LPGs was also not wholly positive. ${ }^{37}$ People's Petitions (Eingaben der Bevölkerung) in the second half of 1971 sent to the ZK agricultural department showed that for farmers across the GDR not all the supply problems in agriculture could be solved overnight. A lack of spare parts continued to render new machines useless, provoking widespread complaints. ${ }^{38}$

The RLN (K)s in different districts also did not immediately improve in their ability to solve the problems of the struggling LPGs/KOGs for which they were responsible. In conjunction with the VIII SED Party Congress in 1971, criticism of the state apparatus for agriculture - particularly with regard to the development of cooperation - had prompted investigation into the functioning of the agricultural councils and their production staff. A report by the SED Bezirksleitung on the working practices of the RLN (B) as well as the RLN (K)s in early 1972 noted, in typical party jargon, 'great differentiation' in the quality of the work done at all levels in the hierarchy of state administration. As usual, however, it was the staff of the RLN (K)s who were found to be severely in need of both more political education and more technical training. ${ }^{39}$ Despite the clear approach set out at the VIII SED Party Congress, the RLN (K)s were not in a position to take action to resolve all divergent trends on their territory with any speed. There were still competing ideas about how, and how quickly, further specialisation and industrialisation of agricultural production should take place.

The idea of establishing wholly separate administration for crop and livestock production, even in the long term, still provoked in 1971 an openly negative response from some collective farmers. In one LPG, an 
SED member argued that if cooperation should be continued at all, then livestock production should be part of the cooperation too. ${ }^{40}$ Pursuing such a plan was rejected on the grounds that it would lead effectively to the formation of a Groß LPG based on the merger of the collective farms in the KOG. Come April 1972, and the RLN (B) had, however, to report that success with regard to the gradual reinvigoration of cooperative crop production was still being overshadowed by widespread desire among farmers to form such large mixed crop and livestock farms. In Kreis Erfurt-Land, the LPGs based in Andisleben, Grossrudestedt and Kerspleben had all begun to expand through mergers. Between the three of them, they occupied more than one-fifth of the district's agricultural land. Similar tendencies were also noted in LPGs in Kreis Eisenach and Bad Langensalza. ${ }^{41}$

While in Kreis Sömmerda and Kreis Apolda more than 70 per cent of land was being farmed in a cooperative unit in 1972, the rest of the Bezirk was by no means so far advanced. Only 20 per cent of land was being farmed in this way in Kreis Worbis and Kreis Sondershausen further to the north, where Type I LPGs in particular had remained resistant to cooperative crop production. In the Bezirk as a whole, seventy-two cooperative crop production units (Kooperative Abteilungen Pflanzenproduktion or KAPs) administered 45 per cent of the farmland, leaving more than half to be farmed by LPGs either independently or in less formal cooperation with one another..$^{42}$ Nonetheless in the course of the next two years, the proportion of farmland officially administered by a KAP increased steadily. Concerted efforts by the SED Kreisleitung and the RLN (K) ensured that LPG cadres took steps to establish stable cooperative crop production within the KOGs, overcoming rivalries between the individual collective farms and carrying out sufficient consultation with their members before radical steps were taken which had a direct impact on working conditions.

\section{Reconstituting Cooperation}

In January 1973, in a document prepared for Erich Honecker's discussions with the SED first secretaries of the Bezirke, Gerhard Grüneberg's office outlined the current position on agriculture. The document suggested optimistically that there was now unity from top to bottom among all who worked in agriculture in the GDR on the correct policy. To maintain this unity, however, the first secretaries were reminded of the importance of a slow process of transition and real discussion with the farmers themselves before greater concentration and specialisation 
of production was introduced. In order for socialist agricultural policy to be successfully put into practice, it was necessary above all not to undermine the special - traditional - commitment of farmers to the production process. The continuing existence of LPGs, with their structures of inclusion and participation, and the element of proprietary ties to the land for which they stood in theory, if not entirely in practice, were essential to this policy, because they maintained farmers' 'moral and material interestedness'. ${ }^{\prime 3}$

The reorganisation of working patterns, competences and responsibilities in the LPGs as a result of the formation of a separate crop production unit entailed potentially serious upheaval for many LPG members and raised serious doubts about the nature of their future employment: primarily, where and with whom they would be working, and on what basis they would now receive an income for the labour and land they had contributed. During the SED district party activists' assembly for agriculture in September 1972, a representative of the KOG Sömmerda spoke of the need to strike the balance between taking into account the wishes of the individual LPG member and moving forward with formation of a separate crop production unit: 'We will take on no member, who hasn't been spoken to; we will take on no member where a signed delegation agreement has not been presented and we will accept no cadre files where the questionnaire has not been filled out.' ${ }^{44}$ Prior to the establishment of the KAP Stotternheim/Grossrudestedt in Kreis Erfurt, for example, careful attention was paid to ensuring that the personal objections of the individual members were aired and dealt with before the KAP was set up. Resolutions were passed in the members' assemblies of the LPGs and discussions held with members in their brigades as to who was to be delegated into the KAP and on what basis they were to be paid. ${ }^{45}$

After the VIII SED Party Congress, LPG cadres certainly felt themselves constrained by the need to proceed with developing cooperative relations in line with SED policy and state pressure, and accepted therefore the necessity of forming a KAP. They remained, however, no less keen to avoid any suggestion that they had failed to protect the LPG members' interests, and sought initially therefore to relinquish as little control over LPG finances to the KAP as possible. The question in particular of how to bring about the fair sharing of the profits of the cooperation, given the varying inputs of the LPGs, was at the heart of discussions in the cooperative councils. The leadership of the LPG Type III Tunzenhausen, for example, had to admit in a meeting in January 1972 that: 'the members are sceptical, they want to enjoy the fruits of their labour ... Tunzenhausen', he went on, 'does not want 100 per cent 
cooperation as this will just get disputes started again, especially as far as the sharing of profits is concerned.' With each LPG having different resources, there was considerable contention about how these resources could or should be shared and balanced in the division of profits. As a consequence, LPG chairmen insisted on a certain amount of the financial organisation continuing to be run via the LPGs themselves. ${ }^{46}$

With the formation of a cooperative crop production unit within a KOG, initially often only slight changes were made to the conditions under which collective farmers worked. Most often, the field brigades were divided along territorial lines, such that one - or at the most two LPGs functioned as a subsection of the KAP. As a result, collective farmers could continue to work in their home area. Given that each LPG often continued to receive the produce that yielded from their own fields and used most of their own machinery too, there was little radical changed involved in forming a KAP. ${ }^{47}$ The opinion, 'What grows on the territory of the LPG must belong to the LPG', continued thus to be prevalent, particularly in those LPGs where large investments had been made in recent years in producing certain special crops such as hops and types of fruit. This opinion was also present particularly in those LPGs that had long had better yields on their fields than their neighbours. ${ }^{48}$

Steps towards the creation of cooperative crop production units inevitably saw conflicts over the sharing of profits and resources between the LPGs, especially where no unified system for paying all the KAP employees had been worked out. Attempts to set up a KAP in the KOG Grossbrembach, for example, were seriously undermined by mutual suspicions between members of the various LPGs. On the one hand, tractor drivers from the LPG Grossbrembach decided to return machines and apparatus to the individual LPGs in the KOG, rather than continue to work together with drivers delegated from the other farms, who, they believed, treated the machinery irresponsibly. In their opinion, the other LPGs were living off the back of their hard work and they felt they were being 'continually duped'. In response, the chairman of the LPG Vogelsberg argued that his members had been done out of 250,000 Marks during the sharing of profits. They had been forced to accept a work unit rate of 9.50 Marks compared to the 11 Marks paid in the other LPGs. Furthermore, he pointed out, the development of cooperative crop production had meant the end of his LPG's lucrative line in poppy production. ${ }^{49}$

Despite the occurrence of such disputes, over the course of 1973 continued pressure from the SED Kreisleitung and the RLN (K) on LPG chairmen ensured new KAPs were formed and existing KAPs over- 
came their difficulties. Active support was given to the cooperative councils to ensure the constituent LPGs in the KAP were placed on an equal footing and a uniform system of payment was established for all KAP workers. The RLN (K) helped the members of the cooperative councils set out a plan for establishing a unified level of work units through a unified set of work norms and system of incentives across the constituent LPG, aiming thereby to prevent the sort of disputes which had proved so divisive in the past. ${ }^{50}$ By March 1973, in approximately half of the existing KAPs in the Bezirk, unified work norms had been introduced. ${ }^{51}$

The resolution of essential financial questions lent a degree of confidence to collective farmers faced with the prospect of working in a KAP. The idea of cooperative crop production was no longer dismissed out of hand. As long as the incomes of the LPG members were protected and there was confidence in the efficiency of the new structure and organisation of work, the KAP appeared to receive greater acceptance among LPG members. In discussions with farmers in February 1973 in Kreis Erfurt-Land, the step to cooperative crop production was now positively compared with the step from private to collective farming: 'Everything new has to get properly settled. In 1960 during the formation of the LPG, there were people who could already see their downfall. But everyone has developed since then and no-one has been ruined. ${ }^{52}$

\section{A New Structure for Agriculture - A New Context for SED Authority}

During the early 1970s considerable transition was taking place in many of the Type I LPGs in the Bezirk, which had up until this point successfully guarded their independence. It was becoming increasingly apparent to members of Type I LPGs that they would not be able to continue in this way for much longer. Where financial hardship had not yet forced Type I LPGs to merge with their neighbours, the RLN (K) were bound to take action to end the anomalous existence of the remaining Type I LPGs in the Bezirk. Merger with a neighbouring LPG Type III was still often a bitter pill to swallow. Eingaben received by the ZK Agricultural Department during the third quarter of 1972 contained several from members of Type I LPGs, complaining about the level of contribution they were required to pay the LPG Type III to ensure there was no loss of capital funds per hectare after the farms had merged. Sums of between 2,500 and 3,500 Marks per hectare were felt by those Type I members 
with few animals left to offset this sum to constitute a crippling burden. ${ }^{53}$ However, there were, by 1973, considerably fewer collective farmers who were willing to struggle to continue to maintain their independence than there had been five years previously.

For the considerable proportion of LPG Type I members who were approaching or had even surpassed retirement age, there was some relief in the prospect of not having to struggle on fulfilling state demands for increased production. An analysis of Type I LPGs in 1972 had already identified the extreme age of their members as reaching crisis levels. ${ }^{54}$ For the rest of the remaining Type I farmers, attempting to hold on to independence appeared increasingly futile given the now clear direction of SED policy towards separate intensification of crop and livestock production, and was likely only to bring further financial penalties. Merger or transfer of livestock into a collective herd and participation in cooperative crop production increasingly seemed therefore the only viable option for these LPG members. In a few cases the prospect of merger was mitigated by the fact that those farmers who wished it were sometimes allowed to maintain an extended number of livestock privately for a certain amount of time beyond the date of the merger. ${ }^{55}$ By January 1974, the number of animals held in Type I LPGs had been dramatically reduced as a result of mergers and switching to a higher LPG Type. In Bezirk Erfurt only 2.8 per cent of cattle, 2.3 per cent of pigs and 1.4 per cent of sheep were now being held in the remaining forty-nine Type I LPGs. ${ }^{56}$

The merger of LPGs and the formation of the KAPs had brought with it a reconfiguration of the leading personnel in agriculture at a local level. Above all, it provided opportunities for SED members to be established in positions of influence over wider areas of production. Specifically in Bezirk Erfurt, a new generation of functionaries, trained in the latest socialist agricultural theory and methods and largely loyal to the SED, had taken positions as heads of KAP. ${ }^{57}$ Obstruction of steps towards the formation of separate crop and livestock production by LPG cadres had often been put down by the SED Kreisleitungen to the fears of LPG functionaries themselves of being demoted as a result. There were certainly a number of cases in Bezirk Erfurt in which DBD members were considered to be hostile to the development of cooperative crop production. ${ }^{58}$ Whether or not LPG chairmen who were members of the DBD really did obstruct the development of the KAP for fear of losing their positions, the concentration of crop production in the KAP provided an opportunity for the SED to assert its dominance over agriculture. 
During a training week for leading members of the DBD in Kreis Nordhausen, an instructor from the SED announced in a speech that the position of head of the KAP would only go to SED comrades. When challenged about this comment afterwards, on the basis that the head of the DBD in Bezirk Erfurt, Willy Grandetzka, had only recently suggested the opposite, the SED member responded bullishly that Grandetzka would have to revise his opinion too. ${ }^{59}$ In the KOG Grossengottern, for example, changes to cadre positions with the creation of the cooperative crop production unit in August 1972 were the cause for concerned discussion among DBD members. The new administrative construction of the KAP was described by DBD members, who considered themselves to have been demoted compared to their former positions, as a 'great changing of the guard'. Some even asked to join the SED instead, if this would allow them to hold their functions. ${ }^{60}$ By the end of the year, complaints were still arriving from DBD members at Grandetzka's desk. In Grossengottern the KAP head had allegedly told a member of the DBD that he had no chance of being sent to qualify himself at the LPG school in Meissen in the near future, as all SED members would be sent there first and SED members would be the ones occupying the mid- and toplevel functions in the future. ${ }^{61}$

With the settlement of the status of all but a few Type I LPGs, the proportion of land in the Bezirk under the control of LPGs actively participating in cooperative crop production was considerably increased. By 1974 the switch to KAP had been almost completed across the Bezirk. There were now $115 \mathrm{KAPs}$ in the Bezirk with an average size of 3,033 hectares. ${ }^{62}$ Moreover, steps were being taken to revolutionise the conditions of production. Many of the KAPs had already begun to be restructured towards specialised production of particular crops over large areas. In the process, working conditions began to change for those LPG members who had been delegated into the KAPs.

With the development of a different layout of fields and crop rotation, the KAPs began to organise their work brigades on more than the simplest territorial lines, effectively eradicating the old distinctions between LPGs. Work brigades attached to specific territories were to be joined by brigades charged with specific tasks across crop production in general, whose members might come from various LPGs and which might be deployed in various parts of a KAP. ${ }^{63}$ This was a radical departure for the organisation of agricultural production and signalled a considerable change in the status of the agricultural workforce, seeming to break the traditional connection of responsibility between the individual collective farmer and the land and livestock of his LPG. 


\section{Conclusion}

By the mid-1970s, the basic elements of a new stable context in which the SED leadership might seek to exert its authority over agricultural production at the grass roots had been established in Bezirk Erfurt. There were still numerous obstacles to overcome in the organisation of the relationship between crop and livestock production; however, a significant milestone had been reached. With the demise of the LPG Type I, the last remnants of the concessions necessary to large-scale private production had been removed. With the formation of the KAP, any tendencies towards the Groß LPG and the pursuit of the traditional pattern of mixed livestock and crop farms had been abandoned. ${ }^{64}$ At the same time, the process of professionalisation of the agricultural workforce in line with specialisation of production was beginning to make itself felt. Just as the number of agricultural workers had begun to reach a steady level in balance with the machinery and technology available, so a steady ratio of farmers attained a basic qualification in socialist agricultural theory and methods.

Perhaps most importantly, in the mid-1970s the SED as a party was able to achieve a more consistently dominant status within the structures of agricultural production on the ground. Although the SED BPOs continued to vary in their ability, the proportion of party members among collective farmers reached unprecedented levels. More importantly still, the party had established itself firmly among the leading local functionaries determining the manner in which policy was implemented at the front line of farming. A stabilisation of SED authority was thus beginning to take place at the grass roots of agricultural production.

\section{Notes}

1. ThHStAW Bezirksparteiarchiv der SED Erfurt, Bezirksleitung der SED Erfurt IV/C/2/7-356 SED Kreisleitung Erfurt-Land an den Sekretär für Landwirtschaft der Bezirksleitung, Information über den Stand der Bildung der KAP Stotternheim/Grossrudestedt, die gegenwärtig stehenden Probleme und der sich daraus ergebenden Schlussfolgerungen für die Leitungstätigkeit, 1.3.1973, p. 83 .

2. See for example the collection of essays in A. Schildt, D. Siegfried and K. Lammers (eds), Dynamische Zeiten, Hamburg, 2000.

3. Siegfried Kuntsche pinpoints the positive impact of the New Economic System and the Agricultural Councils in enabling the LPGs a greater degree of self-determination over the development of their production facilities 
during the 1960s, which in turn encouraged greater identification with the LPGs. In contrast, the 1970s saw greater centralisation of state control over investment and limitation of local autonomy. Kuntsche, 'Die Umgestaltung der Eigentumsverhältnisse und der Produktionsstruktur in der Landwirtschaft', in Ansichten zur Geschichte der DDR, Vol. 1, eds D. Keller et al., Bonn, 1993, pp. 204-9.

4. This was the comment of farmers interviewed by Christel Nehrig. C. Nehrig, 'Das Leben auf dem Lande: Die Genossenschaften (LPG)', in Befremdlich Anders: Leben in der DDR, ed. E. Badstübner, Berlin, 2000, pp.195-216, here p. 216.

5. SAPMO BArch IV 2/2.023/36 Büro Gerhard Grüneberg, Die 5. Tagung des Zentralrats der FDJ am 22. und 23. April 1960, Discussionbeitrag, p. 90.

6. ThHStAW Bezirksparteiarchiv der SED Erfurt, Bezirksleitung der SED Erfurt IV/C/2/7-344 SED Bezirksleitung Abt. Landwirtschaft, Analyse und Probleme der Entwicklung des gesellschaftlichen Lebens in den Gemeinden des Bezirkes, 27.3.1972, pp. 14-35.

7. I. Merkel, Utopie und Bedürfnis: Die Geschichte der Konsumkultur in der DDR, Cologne, 1999, p. 353.

8. ThHStAW RdB Erfurt L041313 Referat für Ratssitzung - Genosse Kummer (Experiment), 22.8.1968.

9. ThHStAW RdB Erfurt L015464 Bezirksplankommission, Information über die von der Bezirksplankommission für die Bilanzierung der Planangebote AK-Entwicklung und Neueinstellung von Schulabgängern für eine Berufsausbildung 1968 zugrundegelegten Kennziffern, 21.3.1967.

10. D. Langenhahn and S. Roß, 'Berufskarrieren von Frauen', in Sozialistische Eliten: Horizontale und Vertikale Differenzierungsmuster in der DDR, ed. S. Hornbostel, Opladen, 1999, pp. 147-62.

11. B. Van Hoven, 'Women at Work - Experiences and Identity in Rural E. Germany', Area 33(1), 2001, pp. 38-46.

12. ThHStAW Bezirksparteiarchiv der SED Erfurt, Kreisleitung der SED Sömmerda IV/B/4.10/214 SED Kreisleitung, Abt. Staatsfragen, Einschätzung der Durchsetzung der Aufgaben der vorangegangenen Plenum und vor allem des VII. Parteitages, 16.8.1968, p. 2.

13. ThHStAW Bezirksparteiarchiv der SED Erfurt, Kreisleitung der SED Sömmerda IV/A/4.10/092 SED Kreisleitung, Genosse Hermann, Sekretär der SED Kreisleitung an Genossen Friedrich, Sekretär der Bezirksleitung, Abt. Agit./Prop, 29.5.1967, p. 74.

14. ThHStAW RdB Erfurt L1075 Band I Bezirkslandwirtschaftsrat, Vorsitzender an den Vorsitzenden des Rates des Bezirks, Probleme, die sich aus der Einführung der 5-Tage Arbeitswoche in der Landwirtschaft ergeben, 23.12.1965.

15. ThHStAW RdB Erfurt L1158 Bezirkslandwirtschaftsrat, Information über die durchgeführten Jahresendversammlungen in den LPG im Bezirk Erfurt, 12.1.1966.

16. BArch DK 1 VA Neu 2846 Landwirtschaftsrat der DDR, Information zu einigen Problemen der Verfassungsdiskussion in den sozialistischen Betrieben der Landwirtschaft, 1.3.1968. 
17. ThHStAW Bezirksparteiarchiv der SED Erfurt, Bezirksleitung der SED Erfurt BIV/2/7-497 Information über die durchgeführten Kreisbäuerinnenkonferenzen, 14.6.1963, p. 83; IV/A/2/2-38 Protokoll der Bezirksparteiaktivtagung Landwirtschaft am 17.12.1963, Referat Genosse Thieme, Stellv. Leiter des Büros für Landwirtschaft, p. 22.

18. ThHStAW RdB Erfurt L036207 Land-, Forst und Nahrungsgüterwirtschaft, Abt. Veterinärwesen, Bericht zur Konzeption für die Untersuchung der objektiven und subjektiven Ursachen der Tierverluste, 16.8.1971.

19. SAPMO BArch DY60/2973 DBD Bezirksvorstand, Abt. Parteiorgane, Wertung des weiteren Verlaufs der Diskussionen zur Vorbereitung des Perspektivplanes, 21.9.1970.

20. SAPMO BArch DY60/2973 DBD Bezirksvorstand, Abt. Parteiorgane, Weitere Kurzeinschätzung über Verlauf und Ergebnisse der Diskussion in MV und in der politischen Massenarbeit zur Vorbereitung des Perspektivplanes und zur weiteren Anwendung des ÖSS, 10.9.1970.

21. J. Rösler, Zwischen Plan und Markt: Die Wirtschaftsreform, 1963-1970, Berlin, 1990, p. 147.

22. Siegfried Kuntsche refers to such measures to centralise control over investment and accumulation as an erosion of the autonomy that the LPG had enjoyed under the NÖS. The loss of independence, bound up with the loss of incentive in turn, he suggests, was a severe blow to LPG members' traditional identities as farmers. Certainly it was a turning point for the remaining members of Type I LPGs. Kuntsche, 'Die Umgestaltung der Eigentumsverhältnisse', pp. $206 \mathrm{ff}$.

23. ThHStAW Bezirksparteiarchiv der SED Erfurt, Bezirksleitung der SED Erfurt IV/B/2/5-184 SED Bezirksleitung Abt. Parteiorgane, Kurzinformation Nr. 54, 22.6.1970, pp. 142-4.

24. ThHStAW Bezirksparteiarchiv der SED Erfurt, Bezirksleitung der SED Erfurt IV/B/2/5-165 SED Bezirksleitung Abt. Parteiorgane, Kurzinformation Nr. 57/70, 13.7.1970, p. 491.

25. SAPMO BArch DY60/2973 DBD Kreisvorstand Heiligenstadt, Information, 17.7.1970.

26. ThHStAW Bezirksparteiarchiv der SED Erfurt, Bezirksleitung der SED Erfurt IV/B/2/5-165 SED Bezirksleitung Abt. Parteiorgane, Information aus der operativen Tätigkeit, 30.7.1970, p. 513.

27. SAPMO BArch DY60/2973 DBD Bezirksvorstand, Abt. Parteiorgane, Parteiinformation, 11.8.1970.

28. ThHStAW Bezirksparteiarchiv der SED Erfurt, Kreisleitung der SED Sömmerda IV/B/4.10/211 SED Kreisleitung Abt. Parteiorgane, 'Wie wird die Lage in den einzelnen Orten eingeschätzt?' 19.2.1970, p. 162; Rat des Kreises, Kreiswahlbüro, Bericht über die durchgeführten Rechenschaftslegungen in Vorbereitung der Volkswahlen sowie über die Eingabenbewegung, p. 182.

29. ThHStAW Bezirksparteiarchiv der SED Erfurt, Kreisleitung der SED Sömmerda IV/B/4.10/148 SED Kreisleitung Abt. Agit./Prop, Gesichtspunkte eines Beschlusses des Politbüro vom 5.10.1970, Zu inhaltlichen Problemen der politischen und ideologischen Arbeit und ihre Wirksamkeit, 10.11.1970, pp. 49-66. 
30. SAPMO BArch DY30/ IV A 2/2.023/2 Büro Gerhard Grüneberg, Analyse der Vorschläge, Hinweise und Kritiken der Werktätigen in der Landwirtschaft und Nahrungsgüterwirtschaft in Vorbereitung des VIII. Parteitages der SED, 10.5.1971, pp. 116ff.

31. SAPMO BArch, DY60/2958 DBD Kreisverband Gotha, Abt. Parteiorgane, Parteiinformation, 2.4.1971.

32. ThHStAW Bezirksparteiarchiv der SED Erfurt, Bezirksleitung der SED Erfurt IV/B/2/5-410 DBD Bezirksvorstand an den Sekretär für Landwirtschaft der SED Bezirksleitung, Sozialistischer Wettbewerb nach dem Beispiel Tuchheim, 15.2.1971, pp. 229-34; DBD Bezirksverband an die SED Bezirksleitung, Vorschläge unserer Mitglieder aus MV, differenzierten Beratungen und persönlichen Aussprachen, 4.5.1971.

33. SAPMO BArch DY60/2958 DBD Kreisvorstand Arnstadt, Einschätzung der Meinung der Mitglieder unseres Kreisverbandes zum VIII. Parteitag der SED, 24.6.1971.

34. SAPMO BArch DY30/IV A 2/2.023/50 Büro Gerhard Grüneberg, Hausmitteilung, Dr. Feil an Genossen Grüneberg, Stellungnahme zur 'Analyse der Preisentwicklung wichtiger Produktionsmittel für die Landwirtschaft', 28.6.1971; Information für Genossen Kiesler, 'Im Zusammenhang mit den Untersuchungen zur Preispolitik und den dazu notwendigen Berechnungen ...' 26.7.1971; Information über weitere Manipulationen der Staatlichen Zentralverwaltung für Statistik und des Amtes für Preise bei der Darstellung der Industrie- und Baupreisentwicklung, 28.7.1971; Untersuchungen zur Preispolitik - Teil Landwirtschaft, 24.8.1971.

35. ThHStAW Bezirksparteiarchiv der SED Erfurt, Kreisleitung der SED Sömmerda IV/B/4.10/101 SED Kreisleitung Abt. Parteiorgane, Einschätzung der MV - Monat Oktober, 8.11.1971, p. 356.

36. ThHStAW Bezirksparteiarchiv der SED Erfurt, Kreisleitung der SED Sömmerda IV/C/4.10/073 SED Kreisleitung Sekretariat, Protokoll über die Kreisparteiaktivtagung am 25.9.1972, 27.9.1972, Diskussionsbeitrag Gen. Freistauer, HB Leubingen, pp. 65-6.

37. SAPMO BArch DY60/2958 DBD Bezirksvorstand, Abt. Parteiorgane, Ergänzender Abschlussbericht über die Arbeit unserer Partei in Vorbereitung und Durchführung der Wahlen am 14.11.1971, 17.11.1971.

38. SAPMO BArch DY30/IV B 2/2.023/24 Büro Gerhard Grüneberg, ZK der SED, Abt. Landwirtschaft, Einschätzung der Eingaben aus der Bevölkerung, 25.1.1972.

39. ThHStAW RdB Erfurt L041299 SED Bezirksleitung, Abt. Landwirtschaft an das Sekretariat, Ergebnisse der Arbeitsgruppe zur Untersuchung der Arbeitsweise der Produktionsleitung des RLN des Bezirkes Erfurt und der Produktionsleitungen einiger Kreise, 9.3.1972.

40. ThHStAW Bezirksparteiarchiv der SED Erfurt, Kreisleitung der SED Sömmerda IV/B/4.10/101 SED Kreisleitung Abt. Parteiorgane, Einschätzung der MV - Monat September, 5.10.1971, p. 344.

41. ThHStAW RdB Erfurt L041299 RLN (B) Information an das Sekretariat der Bezirksleitung Erfurt der SED über den Stand und die Entwicklung horizontaler Kooperationsbeziehungen in der Pflanzenproduktion des Bezirkes Erfurt, 3.4.1972. 
42. ThHStAW Bezirksparteiarchiv der SED Erfurt, Bezirksleitung der SED Erfurt IV/C/2/7-344 SED Bezirksleitung Abt. Landwirtschaft, Analyse und Probleme der Entwicklung des gesellschaftlichen Lebens in den Gemeinden des Bezirks, 27.3.1972, pp. 14-35.

43. SAPMO BArch DY30 IV A 2/2.023/1 Büro Gerhard Grüneberg, Grüneberg an Honecker, Material für die Beratung mit den 1. Bezirkssekretären, 24.1.1973.

44. ThHStAW Bezirksparteiarchiv der SED Erfurt, Kreisleitung der SED Sömmerda IV/C/4.10/073 SED Kreisleitung Sekretariat, Protokoll über die Kreisparteiaktivtagung am 25.9.1972, 27.9.1972, Referat des Genossen Heckmann, Kooperation Sömmerda, p. 58.

45. ThHStAW Bezirksparteiarchiv der SED Erfurt, Bezirksleitung der SED Erfurt IV/C/2/7-356 SED Kreisleitung Erfurt-Land, Information über den Stand der Bildung der KAP Stotternheim/Grossrudestedt ... 1.3.1973, p. 83.

46. ThHStAW Bezirksparteiarchiv der SED Erfurt, Kreisleitung der SED Sömmerda IV/C/4.10/171 SED Kreisleitung Abt. Landwirtschaft, LPG Koop. Sömmerda, Protokoll der Beratung der Vorsitzenden und Parteisekretäre mit Vertretern der Kreisleitung der SED und der Produktionsleitung des RLN, p. 4.1.1972, pp. 1-3.

47. BArch DK 1 VA neu 2464 Ministerium für LFN Abt. Wissenschaftliche Führungstätigkeit und Inspektion, Bericht - Erfurt, 1972.

48. ThHStAW Bezirksparteiarchiv der SED Erfurt, Kreisleitung der SED Sömmerda IV/B/4.10/200 SED Kreisleitung Abt. Landwirtschaft, Stellungnahme zum vorliegenden Bericht der Produktionsleitung über den Stand der Entwicklung der Kooperationsbeziehungen in der Landwirtschaft, 11.10.1971, p. 252.

49. ThHStAW Bezirksparteiarchiv der SED Erfurt, Kreisleitung der SED Sömmerda IV/B/4.10/200 SED Kreisleitung Abt. Landwirtschaft, Fragen zur Entwicklung der Abt. Kooperative Pflanzenproduktion der KOG Grossbrembach (undated), p. 283.

50. ThHStAW Bezirksparteiarchiv der SED Erfurt, Bezirksleitung der SED Erfurt IV/C/2/7-356 RLN (B), Betriebswirtschaftlicher Beratungsdienst, Einschätzung der gesellschaftlichen Entwicklung der Kooperation Greussen, 23.2.1973, p. 33.

51. ThHStAW Bezirksparteiarchiv der SED Erfurt, Bezirksleitung der SED Erfurt IV/C/2/7-356 SED Bezirksleitung Abt. Landwirtschaft, Handmaterial zur Information zum Stand der Entwicklung der kooperativen Beziehungen zwischen den LPG, 27.3.1973, p. 144.

52. ThHStAW Bezirksparteiarchiv der SED Erfurt, Bezirksleitung der SED Erfurt IV/C/2/7-356 SED Kreisleitung Erfurt-Land, Information über den Stand der Bildung der KAP Stotternheim/Grossrudestedt, 1.3.1973, p. 83.

53. SAPMO BArch DY30/IV B 2/2.023/24 Büro Gerhard Grüneberg, ZK der SED, Abt. Landwirtschaft, Einschätzung der Eingaben aus der Bevölkerung im III. Quartal 1972, 19.10.1972.

54. SAPMO BArch DY30/1609 ZK der SED Abt. Landwirtschaft, Brief an Genossen Kiesler von Genossen Ewald, Analyse über einige Hauptprobleme des gegenwärtigen Entwicklungsstandes der LPG der Typ I. 
55. D. Gabler, Entwicklungsabschnitte der Landwirtschaft in der ehemaligen DDR, Berlin, 1995, p. 227; Staatliche Zentralverwaltung für Statistik, Bezirksstelle Erfurt, Statistisches Jahrbuch - Bezirk Erfurt, Vol. I, p. 173.

56. ThHStAW Bezirksparteiarchiv der SED Erfurt, Bezirksleitung der SED Erfurt IV/C/2/7-344 SED Bezirksleitung Abt. Landwirtschaft, Faktenmaterial zum Stand und zur Entwicklung der Landwirtschaft des Bezirkes, 13.12.1974, pp. 85-96.

57. ThHStAW Bezirksparteiarchiv der SED Erfurt, Bezirksleitung der SED Erfurt IV/C/2/3-164 SED Bezirksleitung Abt. Landwirtschaft, Material für die Mitarbeiterberatung am 27.8.1973, p. 184.

58. ThHStAW Bezirksparteiarchiv der SED Erfurt, Kreisleitung der SED Sömmerda IV/C/4.10/171 SED Kreisleitung Abt. Landwirtschaft Information über die Aussprache in der Kooperation Büttstädt zur Entwicklung der Kooperation in der Feldwirtschaft, 12.1.1972, pp. 4-9.

59. ThHStAW Bezirksparteiarchiv der SED Erfurt, Bezirksleitung der SED Erfurt IV/C/2/15-517 SED Bezirksleitung Abt. Landwirtschaft Aktennotiz, p. 39.

60. ThHStAW Bezirksparteiarchiv der SED Erfurt, Bezirksleitung der SED Erfurt IV/C/2/15-517 SED Kreisleitung Mühlhausen an die Bezirksleitung Abt. Parteiorgane, Information, 30.8.1972, p. 30.

61. ThHStAW Bezirksparteiarchiv der SED Erfurt, Bezirksleitung der SED Erfurt IV/C/2/15-517 SED Bezirksleitung Information an den Bezirksvorsitzenden der DBD, 21.12.1972, p. 42.

62. ThHStAW Bezirksparteiarchiv der SED Erfurt, Bezirksleitung der SED Erfurt IV/C/2/7-344 SED Bezirksleitung Abt. Landwirtschaft, Faktenmaterial zum Stand und zur Entwicklung der Landwirtschaft des Bezirkes, 13.12.1974, pp. 85-96.

63. ThHStAW Bezirksparteiarchiv der SED Erfurt, Bezirksleitung der SED Erfurt IV/C/2/7-356 SED Bezirksleitung Abt. Landwirtschaft, Handmaterial zur Information zum Stand der Entwicklung der kooperativen Beziehungen zwischen den LPG, 27.3.1973, p. 144.

64. Some elements of the debate for and against the Groß LPG are discussed in: D. Langenhahn, "“Wir waren ideologisch nicht ausgerichtet auf die industriemässige Produktion." Machtbildung und forcierter Strukturwandel in der Landwirtschaft der DDR der 1970er Jahre', in Zeitschrift für Agrargeschichte und Agrarsoziologie 2(51), 2003, pp. 47-55. 


\section{of 8}

\section{Stabilisation and STAgnation}

If the fodder is good and the earnings are right, there'll be no negative discussions ... ${ }^{1}$

(A comment by a board member in the LPG Buttstädt prior to a merger with the neighbouring LPG Essleben and the formation of a cooperative crop production unit.)

After a long period of social, political and economic transformation in the countryside, marked not least by conflict and compromise with collective farmers, the SED leadership could now exert its authority in a changed context. By the mid-1970s, SED policy was being implemented and the rural economy assessed and coordinated on new terms, providing a more stable foundation for further socialist modernisation in agriculture. Collective farmers and the state administration of agriculture in the districts were no longer so antagonised by conflict and uncertainty over the fundamental direction of agricultural development. Consequently, without the overt hostility to transformation among collective farmers that had characterised previous years, steps began to be taken. The administrative separation of crop and livestock farming was consolidated and the process of intensification and specialisation of production in agriculture advanced more rapidly.

The district state administration and LPG cadres could now be relied upon to be consistent in communicating SED policy to collective farmers. They acted with the backing of a more substantial and in most cases more efficiently run SED party organisation than had been the case five years previously. ${ }^{2}$ With the terms of their participation in agriculture thoroughly transformed, collective farmers had no choice, but also often no desire, but to pursue their interests as far as possible in the context of the new structure of agricultural production, rather than in spite of it. By the same token, however, a heavy burden of expectation now rested on the SED leadership to prove the worth of the socialist modernisation of agriculture in improving the incomes and the working conditions of the agricultural workforce.

Although the early 1970s saw improving productivity levels in agriculture, there were, even then, signs that the structures now in place to 
regulate agricultural production at the grass roots were prone to causing imbalances in the relationship between crop and livestock farming. As early as 1971 a small number of leaders of advanced KAPs had already begun to assert a degree of independence, motivated by the financial incentives to specialise in the production of a particular crop. In so doing they had, however, proved themselves unheeding of the concerns of LPG chairmen over the damage to the supply of livestock feed which such specialisation might entail. ${ }^{3}$ Establishing effective relations between crop and livestock farms continued to be a problem throughout the decade.

By 1980 general economic decline threw into stark relief the failure of agricultural functionaries in the district state and party apparatus and the LPG/KAP to regulate increasingly chronic imbalances in the relationship between crop and livestock farms. Arguably, with the completion of the separation of crop and livestock production and the concomitant reconfiguration of the agricultural workforce, the structures of agricultural administration had stabilised. Nevertheless, the terms on which stability had been achieved could not protect against - and indeed exacerbated - grounds for discontent among collective farmers in the coming years.

\section{Consolidation and Conflict}

During the second half of the 1970s, throughout the Bezirk, KAPs began to merge with one another, increasing the size of individual field plots and expanding the potential for large expanses of monocultural production. Along with this process of expansion and specialisation came further steps to develop the work organisation within the crop production farms. Brigades were increasingly organised according to specific tasks, rather than purely specific areas of the farm, in an attempt to concentrate and deploy, in the most rational way, the skills and machinery available. This entailed bringing to an end the connection between the individual farmer and a particular territory. What remained of the intimacy of understanding of local conditions, the inherited relationship between the farmer and his land and his locality were deemed in practice increasingly irrelevant, at least on the scale which had hitherto been the case. ${ }^{4}$

At this stage, however, there were few reports of serious expressions of hostility to the new arrangements from collective farmers. Although the configuration of brigades and the prospect of working on distant territories was not always a welcome change, there was little to be gained 
by opposing it. Greater quality and quantity of yields were now more widely seen by collective farmers to be primarily attainable via processes which occurred on a grand and necessarily supra-local scale. Having accepted the dilution of their rights to participate in the running of the farm and their rights to local self-determination, as a result of the expansion of the KAPs, there was nevertheless the expectation that at least incomes would be steadily improved. ${ }^{5}$

Deployment of manpower and use of modern machinery, the systems of spreading fertiliser and pesticides, irrigation and drainage and the specialisation in particular cultures could occur most efficiently with as little territorial division within the crop farm as possible. Yet, the growing irrelevance of old boundaries between collective farms and the greater unity and coherence of the KAPs could be potentially problematic. In particular, the relationship between the leaders of KAPs and their nominal superiors, the chairmen of the LPG, became increasingly anomalous. As the structures and work organisation of the cooperative crop production units ceased to bear direct correlation to the constituent LPGs, so the ongoing sharing of administrative competence between KAP leaders and LPG leaders became increasingly difficult to uphold, not least on a personal basis.

The KAP was in theory still a subordinate structure to the LPG within the context of the cooperative community and hence was financially bound to the constituent collective farms. Yet, as the primary producers of the feed on which several collective farms relied and as the financially dominant institution in any cooperative community, this subordinate position appeared to be increasingly anomalous in practice. LPG chairmen had official seniority and an obligation to ensure that the LPG as an institution retained its dominant position. They were also duty-bound to ensure the LPG, as a livestock farm, was well served by the cooperative crop production unit. KAP leaders were, however, equally beset by demands. They were required to balance the not always equally influential demands of the various LPGs in their vicinity with the demands of the state, as well as seeing to their own financial security. Given the complexity of maintaining this balance of interests, it is perhaps unsurprising that relations between chairmen of LPGs and the leaders of KAPs could easily become fractious. ${ }^{6}$

The institutions which had grown up out of cooperation between LPGs - such as the KAP - were not officially to be regarded as independent structures. They were certainly not to undermine the fundamental importance of the LPG as the dominant administrative structure through which agriculture was to be regulated on the ground and the interests of collective farmers represented. However, it was clear to most 
farm managers, particularly as KAPs merged and established a complex internal structure and work organisation, that, although merely transitional institutions, the cooperative crop production units would (sooner rather than later) become de facto independent of their constituent LPGs. Uncertainty over how and when this would occur made for still more unease. During the early 1970s local agricultural administration was thus marked by instances of petty conflict and recrimination as the heads of KAPs sought to cut the ties of dependency on the LPGs as quickly as possible, while LPG chairmen strove nonetheless to maintain their authority. ${ }^{7}$

The step from KAP to independent LPG for Crop Production (LPG Pflanzenproduktion or LPG P) - from a transitory to a legally permanent, independent institution - occurred at different rates. Some model specialised LPG Ps had already been set up in Bezirk Erfurt after the VIII SED Party Congress in $1971 .{ }^{8}$ In the course of 1975 steps began to be taken in a small number of KOGs in Bezirk Erfurt to establish several more LPG Ps and thereby impose some order on the strivings for independence among some KAP heads. ${ }^{9}$ Those collective farmers who had technically been delegated from the LPGs into the KAP received thereby a new status as members of a wholly separate new LPG P. In the process their right as a member of an LPG to participation in the running of the collective farm in which they were employed was reasserted, as was their right to a household plot, which in some KAPs had provisionally been denied. Parallel to the LPG Ps, LPGs for Livestock Production (LPG Tierproduktion or LPG Ts) were formed out of what remained of the original collective farms, be it the cooperative livestock production facilities which had been set up between LPGs or the remnant livestock production in the individual farms themselves.

During the course of the next four years KAPs began gradually to transfer to LPG Ps, and LPG Ts formed with varying degrees of specialisation. Although the formation of LPG Ps and LPG Ts resolved the ambiguous status of delegated LPG members and set the relationship between heads of crop and livestock farms on a new footing in theory, it did not resolve in practice all of the problems of the relationship between crop production and livestock production. The difficulties of coordinating the interests of LPG Ps and LPG Ts in the context of a shortage economy proved increasingly unmanageable as the 1970s drew to a close.

Ideally, the formation of large-scale crop farms with an advanced system of work organisation and specialisation of particular cultures would enable large overall increases in productivity. Increased consumer demand would be met, levels of agricultural imports would be 
reduced and the demand for feed from ever-larger livestock holdings satisfied. With greater productivity in livestock farming, it was hoped too that production well in excess of domestic demand could be exported to gain valuable foreign currency. For this ideal situation to be realised, however, productivity from crop production farms would have to increase steadily, matching the demands of increasing numbers of livestock held in the country. As it happened, such consistent increases proved ultimately unattainable in practice, given the competition across the East German economy for essential materials and financial investment. The negative consequences of these limitations on production had real consequences for those communities dependent on agricultural production.

Amid a worsening economic situation in the GDR during the later 1970s, prompted not least by international oil crises, the relatively low status of agriculture within the SED's investment priorities severely tested the efficiency with which the relationship between separate crop and livestock farms was regulated. In such straitened circumstances, neither the leading cadres of the LPGs and KAPs nor the agricultural functionaries of the state administration in the Bezirk, nor indeed the SED Kreisleitungen were effective in preventing some serious imbalances in the distribution of funds and resources to livestock farms.

As a consequence, working conditions, particularly in the smaller livestock farms, failed to improve and in some cases steadily worsened. Not only was there a shortage of feed available to feed the animals and maintain productivity, the rising costs facing LPG Ps and KAPs were also being passed on to livestock farms, reducing still further their ability to fund improvements to production facilities and working conditions. Those working in the increasingly deprived livestock farms found themselves hard pressed and thoroughly demoralised by the constant struggle to maintain productivity despite limited equipment and an irregular supply of fodder. Meanwhile, the economic problems faced by struggling LPGs manifested themselves in the loss of funds available for improvements to the communities in which they were based.

\section{Inadequate Industrialisation}

Given the state of agricultural development at the end of the 1960s, continuing the project of creating and then sustaining truly modern industrial production in agriculture during the 1970s could not be achieved cheaply. It required heavy initial investment in construction for storage and preparation of crops, as well as for intensive livestock holding. 
However, it also required continuous investment to provide the buildings with heat and light and to sustain a regular supply of machinery and vehicles as well as the fuel to run them. In addition, there were a number of other expenses arising in part from the scale of production. Money had to be found for medicines for livestock, which were prone to mass outbreaks of disease when kept in large numbers in such close proximity to one another, as well as for chemical fertiliser and pesticides for crops planted in large open expanses, on not always wholly suitable land. Where the money to pay for the transformation of agriculture would come from was no easy matter to solve.

Despite the expense, there was a general reluctance in the SED leadership to risk popular discontent by passing on some of the cost of production to the population. Motivated by the spectre of the 17 June 1953 uprising as well as the loss of face sustained by the SED leadership during the shortages at the end of the Ulbricht era, Honecker remained consistently opposed to cutting price subsidies for the population. At the same time, the limits to which resources could be gained from collective farmers themselves appeared to have been reached. There could certainly be no reduction in income levels for farmers. Furthermore, particularly once the last vestiges of private production in the Type I LPGs had been subsumed into the Type III LPGs, there were no obvious resources left in private hands to exploit. As a result, LPGs depended very heavily on state subsidies on the prices they paid for machinery, fuel and other resources, as well as loans to sustain the development of agricultural production. The fact could not be helped, however, that given the limited extent of the GDR's own natural resources - the cost of the raw materials on which the development of agricultural production (and indeed the GDR's industry in general) relied, was heavily dependent on the balance of world trade. During the 1970s, as prices on world markets rose, the cost of production for industry and for agriculture in the GDR rose rapidly, forcing the SED leadership to increase the financial burden on the LPGs themselves, while reducing imports and increasing exports of valuable commodities.

Under better economic conditions, it had been expected that crop production would become still more efficient using intensive methods to achieve dramatic increases in yields. At the same time the construction of intensive livestock sheds was expected to minimise feed requirements while raising productivity. However, by the start of the 1980s the development of such efficient industrial production had proved impossible because growing costs made sustained investment in agriculture prohibitively expensive. Without this sustained investment, however, a prioritisation of resources took place, making for a very uneven indus- 
trialisation of agriculture. In all but a few LPGs, the improvements to working conditions, production facilities and incomes, which had been promised and which farmers had come to expect, failed to materialise. As conditions in some farms steadily worsened, what confidence there had been in the SED leadership to make good on promises of social equality and economic progress was seriously undermined.

\section{The End of 'Realistic Plans'}

As the sector of the economy whose potential for further mechanisation and rationalisation was greatest, it had long been incumbent upon agriculture to accept steady and considerable reductions in its workforce. The departure of rural youth to work in industry had long been encouraged in order to fulfil the ever-increasing demand for labour. Access to machinery and funds to pay for it was thus vital to farms trying to replace lost manpower and improve working conditions for their ageing workforce. A reduction in labour costs in LPGs would certainly have made some funds available with which to purchase machinery and materials for construction. Cuts to farmers' incomes could not, however, be seriously countenanced by LPG managers, well aware of the anger this would cause.

Collective farmers' eventual acceptance of the limitation of their individual rights over (what had once been) their land and livestock depended at the very least on the state's ability to guarantee a steady income. The austerity of the last years of the Ulbricht era, when incomes had been capped in order to raise minimum levels of accumulated capital, could not be repeated. LPG chairmen looked instead to the state to provide additional subsidies, alongside the investment of the LPGs' own capital, in order to sustain the cost of both increasing incomes and the purchase of machinery.

It was also up to the state, of course, to ensure that the machines and materials required by agriculture were actually available for purchase. At the end of 1974 Gerhard Grüneberg had already begun to warn Gerhard Schürer at the State Planning Commission that the supply of combine harvesters was not keeping pace with the reduction in the agricultural workforce as a result of old age and the recruitment of young people to industry. A major side-effect of this imbalance between machinery and a reduced labour force was the requirement that farmers continue to do much manual labour and put in large numbers of overtime hours and forego weekends. Long-awaited and long-promised improvements in working conditions thus remained noticeably absent, 
even if incomes continued to improve. As Grüneberg pointed out to Schürer, 'the situation is such that we are seriously behind in carrying out socio-political measures for collective farmers'. ${ }^{10}$

In this situation Grüneberg was adamant that an increased export of agricultural machinery when it was badly needed at home could ultimately result only in a reduction of agricultural production. This in turn, he argued, would have a damaging effect on working conditions and serve only to undermine further the morale of farmers and with it the legitimising claims of the SED regime. A month later, in a memorandum for Erich Honecker, Gerhard Grüneberg pressed his point home further about the need to improve the provision of machinery for home agricultural development. The successes of the years following the VIII SED Party Congress (1971), he suggested, had been the result of a return to working with 'more realistic plans'.

Such had been the drive for economic efficiency and rationalisation during the period of economic reform under Ulbricht, that impossible advances in productivity had been demanded of agriculture, given the investment made available. In contrast, in the first years of Honecker's period in office, investment had been sufficient to enable real advances in productivity. This had to be sustained. Unless the steady supply of machines and spare parts continued, Grüneberg now argued, it could not be expected of farmers that they continue to increase production. ${ }^{11}$ Despite his lobbying of Erich Honecker, however, it was clear that agriculture occupied a relatively lowly position in the GDR's economic priorities as decided by the SED's leading economic functionaries, notably Günter Mittag and Gerhard Schürer. As long as the current balance in the world economy made it necessary for the GDR to limit its imports and maximise its exports, agriculture would have to make do with what it had already been provided with.

Problems with the supply of essential resources on world markets, particularly oil, had an immediate impact on agriculture in the GDR. In January 1975 instructions were issued by the Rat des Bezirkes Erfurt to the heads of all agricultural enterprises to reduce the levels of fuel used compared with the previous year, with the aim of reducing consumption by 20 per cent. This could not be helped, it was argued, owing to the enormous increase in the price on the world market which had limited the level of imports possible. ${ }^{12}$ In February 1975 a discussion was held in the Rat des Bezirkes outlining some of the economic problems facing the GDR in the coming year. Of primary concern was the fact that the prices for essential raw materials were increasing more rapidly on the world market than prices for finished products, in which the GDR primarily specialised. In order to deal with this the GDR would have to 
increase exports to maintain a balance of trade, reduce imports of raw materials as far as possible and additionally increase its national debt.

Consequences of this problematic situation for rural communities were numerous. Supplies of both consumer goods to the population and machines and materials to agriculture were likely to be badly affected. ${ }^{13}$ With many farms in the midst of upgrading their production methods to an industrial scale with greater mechanisation, the knockon effects of high oil prices on the cost and availability of transport, machinery and construction materials were a severe blow. With some LPGs and KAPs forced to delay construction of larger livestock sheds, land improvement schemes or the purchase of modern machine systems, the gulf in the productivity and working conditions which existed between different KAPs as well as between LPGs even within single districts became increasingly severe. ${ }^{14}$

As the KAPs had merged and expanded to some extent, a similar process of consolidation had occurred in livestock production. However, the progress on this front by the mid-1970s had certainly been both much less rapid and much less consistent. Remaining Type I LPGs had been subsumed into the administration of the Type III LPGs even where no large-scale livestock sheds had been constructed. Neighbouring Type III LPGs, too, merged with each other thus combining their resources, with the goal of specialising (when possible) in a single branch of meat or dairy production or livestock rearing. However, in only a small number of cases had modern intensive livestock holding sheds been constructed by the mid-1970s. The rest of the LPG Ts were not nearly so advanced in terms of either their facilities or their degrees of specialisation. By 1977, although some concentration of production had occurred in most LPGs in Bezirk Erfurt, with the renovation or extension of livestock sheds, a large proportion of livestock continued to be kept in multiple small buildings which lacked even basic labour-saving machinery for feed distribution or manure removal. ${ }^{15}$ Except for a few major centres of livestock holding, most people employed in the livestock farming sector worked in small numbers in several sheds, where conditions had rarely changed significantly since the 1960s. ${ }^{16}$

In the conditions of shortage, there was thus an increasingly obvious stratification of financial and productive status and with them political clout between livestock farms. In August 1975, suggestions by DBD members on how to organise things more effectively pointed out that realistic plans had to be worked out as to how much fodder was actually produced and how much was likely to be consumed by concentrated livestock holdings, at the expense of other livestock holdings in the locality. ${ }^{17}$ Between 1975 and 1976 a number of new large-scale in- 
dustrial livestock holdings were opened in Bezirk Erfurt, among them two enormous concentrated pig farms in Hermstedt and Uthleben. As a consequence, other LPG Ts were to be deprived of a large part of their share of high-protein feed, which in turn would be bound to reduce their productivity. ${ }^{18}$

For the time being, in the mid-1970s, the problems facing agriculture were considerable but did not appear to be insurmountable. There was still room for further increases in production via further mechanisation, concentration and specialisation of production. By 1976 the potential of large specialised production units such as the KAP and LPG P to increase production levels had been proved in Bezirk Erfurt with increases in the gross production of 2.3 billion Marks. At the same time the level of productivity per head of the workforce had also increased by 34.2 per cent on the previous year, even though the level of wages had risen by 11.6 per cent. However, it could not be overlooked that the costs incurred had increased at a faster rate than the increase in gross production. The price of fuel, materials and machinery had gone up, while administrative costs had also increased considerably. ${ }^{19}$ Certainly, industrial-scale production was capable of producing more, but given the economic climate and the cost of essential materials on the world markets this increased production did not appear more cost efficient. Moreover, for the farmers themselves, working conditions and pay did not appear to be improving at anything like the rate they had been led to expect.

\section{Problems of Scale}

The decision to form separate LPG Ps and LPG Ts was confirmed at the IX SED Party Congress in 1976, precipitating the transfer of more KAPs to LPG P status and an even more radical expansion of individual farms. The size of LPG Ps/KAPs formed varied by some 2,000 hectares from district to district, but had in some parts of the Bezirk now reached extraordinary sizes, with those in the largely flat Kreis Sömmerda all encompassing over 5,000 hectares of agricultural land. KAPs in the flatlands could more easily justify merger on the grounds that it enabled the formation of large, continuous fields on which single crops could in theory be most efficiently harvested. ${ }^{20}$ However, the sheer size of these farms presented their own difficulties.

With the expansion of the LPG Ps and LPG Ts to such sizes, individual collective farmers' role in decision making was heavily diluted. They were no longer in a position to judge for themselves easily whether 
or not the farm was being run correctly. In any case, they were subject to a much more dominant SED presence in the LPGs than had previously been the case, which tended to subdue and limit the expression of divergent opinion. LPGs were now run exclusively by highly trained, politically loyal cadres. ${ }^{21}$ As a consequence, however, it seemed that LPG members were beginning to abdicate responsibility for the success or failure of the farm to which they belonged.

In theory, the right to participate in decision making via the members' assembly or the LPG board as well as the continuing right to a household plot had enabled the individual LPG member to maintain his traditional understanding of his profession as a farmer. His motivation to do well ought to rest on more than a desire to increase his wage. The average LPG member was still in theory driven by pride in his collective farm. In practice, however, attitudes among LPG members had undergone a shift, in line with the shift in their experience of agricultural work. Raising incomes was now the only certain means left to LPG chairmen of sustaining the efficiency of the workforce.

In 1977, an overview of farmers' attitudes produced by the Department for Agriculture in the SED Bezirksleitung concluded that the socialist farm had comprehensively demonstrated its superiority over traditional farming. However, it also pointed out that there was an unhealthy reluctance among LPG chairmen to limit the levels of income claimed by their members. Some managers reportedly had adopted the attitude that 'the main thing is making sure the money's good, then the farmers will go along with everything'. ${ }^{22}$ Such comments in some sense broke a taboo. Notionally the transformation of agriculture had occurred without undue damage to farmers' special status as owners and guardians of the land. It also showed up a serious handicap to organising cost-efficient agriculture..$^{23}$ Even as the LPGs failed to reduce other production costs, wage bills too were bound to increase.

The rate of growth of production was now being outstripped by the rate at which money was being spent, compounded by increases in the wage bill. ${ }^{24}$ By 1979, the grand scale of crop production established in the LPG Ps and KAPs appeared to exacerbate rather than reduce the problems of rising costs. On the whole, Bezirk Erfurt was found to be neither especially good nor especially bad in comparison with the other Bezirke. Nevertheless, here as elsewhere the rising costs of production could quite simply not be matched by an equivalent increase in gross production. Although the level of concentration and specialisation in crop production was deemed to be on the whole justifiable in terms of the potential for further exploitation of the natural resources in the Bezirk, it was becoming increasingly difficult to manage the work re- 
quired given the shortage economy. Above all, with crop plantations now on such a large scale, meeting agro-technical deadlines proved increasingly problematic without sufficient supplies of fuel or spare parts for machinery.

In livestock production, too, mergers appeared to fail to improve productivity. An essential reason for the merger of LPG Ts was to reduce the cost of management and spread the number of highly qualified cadres more efficiently. The heads of the new LPGs, like the KAPs, were overwhelmingly SED members in possession of a university or technical college degree. ${ }^{25}$ Furthermore, it was hoped that neglected livestock farms would benefit from a more even share of resources as a result of the mergers. In practice, however, mergers of LPG Ts often brought neither a concentration of resources, nor better management to livestock farming. With so many production sites spread across several villages, LPG chairmen reportedly found overseeing production and raising standards across the board exceedingly difficult. ${ }^{26}$ Unsurprisingly, too, the working conditions in these merged yet unmodernised livestock farms continued to be harsh.

Between 1971 and 1978 a total of 37.8 billion Marks had been invested in agriculture in the GDR. However, from 1975 onwards the decline in manpower in the LPGs, and the shortage of machinery available to balance this decline, had continued to have a negative effect on the rate at which productivity increased. ${ }^{27}$ A report in 1979 on the problem of maintaining a sufficient workforce throughout the farms in Bezirk Erfurt made it clear that here no further reduction could be sustained without a consequent downturn in production capability. ${ }^{28}$ The lack of machinery was certainly becoming an increasingly frequent topic for Eingaben to the ZK's agriculture department by $1978 .{ }^{29}$

On average the GDR was producing more per hectare than it had previously. The average gross turnover in crop production and in livestock production for the years 1974-78 exceeded that of the years 1969-73 in the GDR as in Bezirk Erfurt. ${ }^{30}$ Nonetheless, the progress of agricultural transformation had come at a price which appeared increasingly unsustainable, given the strain under which the East German economy was operating. As the pinch on the economy at large began to be felt, the SED's leading agricultural functionaries in Berlin began to find themselves under increasing pressure. Their colleagues in the ZK began to call into question the level of state investment received by the LPGs. In particular the balance of price policy between industry and agriculture had become a bone of contention. ${ }^{31}$

In a letter to Honecker at the start of May 1978, Gerhard Grüneberg was moved to complain about one memorandum in particular. 
It claimed to demonstrate that the scale of investment in agriculture since 1960 had brought little if any economic benefit and ought to be cut back, to the benefit of industry. In Grüneberg's opinion the memorandum was 'extremely one-sided, tendentious and in several points and figures factually wrong'.$^{32}$ Nonetheless, there was little prospect in these circumstances of more funding being made available to agriculture. In the face of continuing reductions in the quotas of machinery being made available to the LPGs during the late 1970s, the SED's leading agricultural functionaries in Berlin could only continue their calls for investment in agriculture to be sustained in order to balance the decline in the workforce. In particular, they argued, there was insufficient money being planned for agriculture even to maintain their original levels of machinery, let alone expand. Unless alternative economic decisions were made, they predicted, after a period of stagnation production levels would drop. The consequences for communities reliant on LPGs to sustain them were liable to be devastating. ${ }^{33}$

These fears seem well founded. According to the Bezirksleitung in 1978, in Bezirk Erfurt an investment of 1 billion Marks had been made during the past two years to support the introduction of industrialised farming. However, there had by no means been a general improvement in the level of yields produced throughout the Bezirk. Despite their fundamentally similar terrain and quality of soil, the amount of produce per hectare harvested in Kreis Bad Langensalza considerably exceeded that of neighbouring Kreis Erfurt-Land.$^{34}$ Analysing the balance of the economic results for agriculture, the Bezirk Directorate of the Bank for Agriculture and Food Industries found that in 1979 over half the crop production farms in Bezirk Erfurt were struggling to sustain any economic development. LPG Ps' increased costs above all for repairs to ageing machinery had seriously compromised their profitability. ${ }^{35}$ Moreover in 1979 it was reported that in the majority of LPG Ps and KAPs in the Bezirk, problems with the formation of an effective work organisation had not been conducive to reducing excessive costs. ${ }^{36}$

It was, however, livestock farms rather than the LPG Ps which tended to bear the brunt of rising costs and sinking productivity. In 1978 , the lack of feed as a result of a poor grain harvest meant that the demand from LPG Ts could only be met by two-thirds in Bezirk Erfurt as a whole. ${ }^{37}$ As a result of shortages of feed and increases in costs, livestock production farms were thought to be in still worse a condition than the LPG Ps in 1979, with little margin for accumulation and thus little prospect of building up the investment necessary to transform the conditions of production. ${ }^{38}$ 


\section{The Failures of Cooperation}

At one level, the reason for the continuing divide between crop and livestock farms could be found very simply in the absence or inactivity, in practice, of the administrative structures which were intended to regulate and coordinate the relationship. A document prepared for the office of Gerhard Grüneberg, in May 1976, on the future of agriculture noted that cooperative councils had ceased to function effectively in most districts. ${ }^{39}$ No body existed - outside the district state administration - which could actively ensure that a mutually beneficial relationship between crop and livestock production was maintained. The state administration appeared, however, to be unable to broker effective relations between crop and livestock farms.

A particular issue of complaint among the Eingaben sent to the ZK agricultural department during 1976 was the desperate need in livestock farms to replace old machinery and renovate livestock holdings in order to improve conditions for animals and humans alike. The lack of funds available to LPG chairmen to pay for these improvements was put down to the failure in particular of the Rat des Kreises to regulate the setting of feed prices and ensure there was a sufficient supply of feed for livestock, leaving livestock farms at a serious financial disadvantage compared with the LPG Ps and KAPs. ${ }^{40} \mathrm{~A}$ series of discussions held with farmers working with livestock in 1977 in Bezirk Erfurt reiterated these problems ${ }^{41}$ There appeared, however, to be little prospect of resolving these complaints for the time being, as LPG Ps and KAPs tended, often with the backing of the Rat des Kreises, to extend their plantations of market crops at the expense of their feed crops. ${ }^{42}$

Certainly in Bezirk Erfurt, with state approval, essential changes occurred in the use and quality of agricultural land which worked to the disadvantage of livestock farms. Large swathes of land had already been lost during the 1960s to building projects and mining, and, for the period between 1976 and 1980, it was expected that still more largely high-quality arable land would be lost to building, quarrying and water management schemes among other things. At the same time, there were strong financial incentives for LPG Ps and KAPs to use much of their most fertile land for fruit plantations to meet growing public demand. The replacement of this lost arable land by ploughing less fertile meadow and pasture land was bound, however, to lead to a serious overall drop in the productive capacity in the Bezirk.

Rather than reducing the amount of produce made available for public consumption, the brunt of this drop in productive capacity was born 
by a reduction in the amount of feed made available for livestock. On the one hand, there had been a reduction in the amount of pasture land available. On the other, there had been a reduction in the proportion of the yield devoted to providing feed for livestock. Thus while LPG Ps/KAPs met their obligations, the LPG Ts bore the brunt of any shortage. The amount of land available for fodder production per head of livestock dropped steadily between 1970 and 1978, leading inevitably to a stagnation and even a downturn in the productivity of the LPG Ts. Adding insult to injury, stability in the level of yields had clearly yet to be achieved in the GDR's major crops. For all the mechanisation and new technology applied to agriculture, yields remained, as ever, enormously dependent on the clemency of the weather and it was this fluctuation which was passed on to local LPG Ts. ${ }^{43}$

At the end of 1977, the Rat des Bezirkes put forward some suggestions for rectifying the problems faced by the LPG Ts. Conditions in the livestock farms were to be improved by ensuring that LPG Ps were made to contribute money into a fund to pay for investment in future development. If 'unjustifiably high' differences existed in the financial resources of the LPG Ps and the LPG Ts which could be traced back to unfair prices then a financial settlement was to be reached or money contributed into a common fund. ${ }^{44}$ However, in 1978 conflicts between crop production enterprises and livestock production enterprises over the price, quantity, quality and delivery of fodder and the removal of manure continued to run. ${ }^{45}$ An investigation by the Workers' and Farmers' Inspectorate in 1978 into the state of LPG Ts around the GDR noted serious increases in livestock mortality. This, it was concluded, had resulted in part from the inability of the district state authorities to ensure that the interests of the LPG Ts were taken fully into account by crop farms. ${ }^{46}$

The problems of cooperation between LPG Ps and LPG Ts became more critical as economic problems became more serious. While LPG Ps failed to reach expected targets for increases in production, it was essential that the price for this failure was not automatically passed on to the LPG Ts. However, a fundamental lack of common interests between LPG Ps and LPG Ts led to an apparent lack of understanding on the part of the former for the 'financial reproduction process' of the latter. With the cooperative councils, which were intended to broker good relations between LPG Ps and LPG Ts, widely non-existent, there was a tendency for LPG Ps not to give sufficient priority to their partner LPG Ts' needs. In Bezirk Erfurt, although 56.4 per cent of the gross production in agriculture came from livestock production, only 8.2 per cent of the accumulation of capital was carried out by livestock production 
farms themselves. As a result they remained largely beholden to the crop farms for sufficient investment to improve the working conditions of their members as well as to rationalise production. With crop farms failing to produce sufficient yields and thus unwilling to share their profits with livestock farms, the potential for an unequal distribution of wealth between crop and livestock production had increased.

In the GDR as a whole over 12,000 requests were made for withdrawal from an LPG at the beginning of 1978, an increase of over 1,500 on the year before. The majority of those wishing to leave were employed in livestock production, with over a quarter of requests specifically citing poor working conditions in LPG Ts. ${ }^{47}$ In 1980 a similar number made requests to withdraw from the LPGs. More than half of those who made requests to leave LPGs in Bezirk Erfurt cited quite simply a desire for improved living and working conditions. ${ }^{48}$

With the financial burden passed on to the LPG Ts in the form of excessive charges for feed production and delivery, it was essential that the chairmen of the LPG Ps and LPG Ts, who still nominally formed together a cooperative council, maintained communication. The failure of these councils to function, existing on paper alone since the full administrative separation of crop from livestock production, had led to a complete breakdown in communication. The lack of detailed knowledge of (and perhaps also a lack of concern for) the financial position of neighbouring LPGs led inevitably to serious breakdowns in mutually beneficial relations between farms ${ }^{49}$ In the case of the LPG P and the LPG T Töttelstadt it was found that the cooperative council had in effect ceased to exist by the end of 1979. Attempts to resurrect cooperation between the heads of the LPGs were found to flounder on the rocks of bitter disagreement between them..$^{50}$ Even where they did exist, this was no guarantee that it was possible to reach a mutually beneficial agreement.

In November 1976 a meeting of the cooperative council for the KOG Walschleben in Kreis Erfurt-Land was held. The essential conflict of interests was played out here between the agricultural cadres in charge of crop production, those in charge of livestock and those in the state and party administrations at district level attempting to coordinate these two sides of production. In response to the planned supply of fodder offered by the LPG P, which appeared to fall far short of the amount required, the chairmen of the LPG Ts could only counter: 'We cannot recognise this level of fodder production' and 'I will sign no contract which does not guarantee fully our fodder supply'. Although there was general sympathy for their position, the chairmen of the LPG Ts were forced to recognise that they would have to accept the contracted level 
of supply on paper and then seek their own ways to meet their requirements. On the one hand, given its own obligations, the LPG P could not improve its offer, and, on the other, the Bezirk authorities would withhold financial aid from the LPG Ts unless they signed the contract. In the face of this intransigence and the lack of fodder available in the district, there was some desperation among the assembled cadres about where the LPG Ts would find the feed to fill the shortage. At this stage, complaining directly at the $\mathrm{ZK}$ in Berlin appeared to be the only possible solution..$^{51}$

The minutes of a meeting of the cooperative council for the farms based around the LPG P Andisleben, Kreis Erfurt-Land in May 1979 reveal some of the basic difficulties facing LPG cadres trying to coordinate production in both crop and livestock farms. With several livestock farms supplied by the LPG P, large central silos had been constructed from which each was to take his agreed amount. While this reduced transport costs for the LPG P, it increased costs for the LPG Ts and raised mutual suspicion as to whether one LPG was not taking more than its fair share of the silage. As this exchange in the protocol of the meeting demonstrates, the shortage of feed made for strong competition between livestock farms:

K.M. (LPG T): 'We have to get to the stage where every LPG has its own silo and farms with that.'

G.B. (LPG P): 'It will continue to be the case that we have a few central silos from which several LPGs collect.'

K.D. (LPG T): 'There are always LPGs which don't stick to the agreements.'

M.S. (LPG T): 'Sort things out in your patch before you go into other people's.'

With the news that the Rat des Bezirkes was organising extra silage to be purchased from elsewhere outside the district which would have to be transported in, the chairman of the LPG P made a telling comment: 'Actually over there is where the cattle belong. That's what you were thinking too. This is no situation to be in - you are always hungry and we always get the blame.' In other words, the real problem was that no effective balance had been struck in the Bezirk between the quantity of livestock held in any one area and the amount of land which was devoted to providing feed for them. ${ }^{52}$ It had been for precisely this reason that the administrative separation of crop and livestock production had been opposed in the first place.

A form of agriculture had been developed in the GDR which had shown, and continued to show, its potential for extraordinary levels 
of yields. However, in order to sustain these levels, steady access to machinery, fuel and chemical fertiliser and pesticides were necessary at an affordable price, given the limitations of the GDR's budget. As these resources became more scarce prices rose for crop production, making LPG Ps unprofitable unless they in turn passed on their additional costs to livestock production. LPG Ts, however, also suffered from a shortage of machinery and fuel. Moreover, given the cost of feed and the limits to the amount with which they were supplied, livestock farms found themselves unable to maintain their levels of production, let alone develop the number of animals they kept or the efficiency of the facilities in which they kept them.

Without the prospect of progress in the production facilities, there was little hope for improving conditions for those working in poorer LPG Ts. This had serious consequences for certain villages whose importance as sites of employment and settlement, and thus of commerce, was rendered increasingly obsolete. A vicious circle was created and fuelled by the separation of crop and livestock production which could only drive on an unequal differentiation of living standards between communities in the East German countryside.

\section{Rural Development under Honecker}

Following the completion of the transition of power within the SED leadership from Walter Ulbricht to Erich Honecker, at the VIII SED Party Congress in 1971 there was some optimism among farmers and agricultural functionaries alike that a change in course would rectify some of the economic problems which had manifested themselves so clearly in the years before. Initially, reports from the DBD in Bezirk Erfurt in November 1971 indicated that improvements had yet to make themselves felt. Complaints continued to be directed at the corruption of the system of supply between industry and agriculture which had developed during the bottlenecks of the late 1960s. Spare parts could in fact be obtained, it was rumoured, if one was willing to grease the palm of the supplier. To add insult to injury, the black market was reportedly open to inflation - as one DBD member put it: 'What one got a few years ago for an extra 20 Mark note, is only possible these days with an extra 50 Mark note. ${ }^{53}$ Clearly, as greater investment was made in the provision of consumer goods, rural communities were able to benefit along with the rest of the population. Nonetheless the sense remained among LPG members that they were being given less than those who worked in industry. 
Disparities in living standards between individual rural communities began, too, to become more pronounced. Some villages benefited from becoming new centres of industrial-style agricultural production. New housing was constructed to meet increased demand for living space from an expanded workforce and additional investment was made available by both the state and collective farms and agricultural industries based in the village to improve local infrastructure and amenities. Better road and rail connections to the district capital in their turn enabled access to a wider range of shops and services, and ensured that these villages retained a commuter population, which might otherwise have been forced to move elsewhere. The expansion of industry into the countryside enabled a number of villages to retain a reasonably large working population and thus a status as a regional centre. Other villages similarly continued to benefit from their close proximity to major urban centres and major industries, such as mining.

The long-term prospects for many other rural communities were considerably worse, however. With a declining agricultural workforce and struggling livestock farms, those villages - particularly those without a large commuter population - began to decline in status. As the young moved away to towns and industry, residents of these villages found that they were less and less able to make a persuasive economic argument for state investment in new amenities. At the same time, local collective farms could not be relied upon to provide the sustained financial or material support needed to fund improvements to local infrastructure. Roads were allowed to fall into disrepair, village shops and restaurants began to close and communal facilities, once paid for by the LPG, ceased to run.

Habitable housing was a particular problem in rural communities. The provision of state investment in modern housing made sense in certain key, expanding, villages. New housing and materials for renovation, however, were desperately required elsewhere too.$^{54}$ From the early 1970s onwards, solutions to the housing problems in rural areas were sought in encouraging LPGs to support the aspirations of their members to go about constructing their own homes. This was a boon to those who were able to find the resources to do so. Certainly as early as 1971 the mayor of Gernrode cited the positive response of villagers at the announcement of new plans to encourage people to build their own homes in line with the VIII SED Party Congress. ${ }^{55}$ In 1979 it was reported with some pride that in Kreis Sömmerda, seventeen houses had been built over the course of the last three years thanks to cooperation between the LPGs and the local state organs. Nonetheless, considering the size of the problem of housing in rural areas, such advances were 
clearly not sufficient to resolve the issue. There were now also numerous complaints from LPG members who had been unable to gain access to the building materials they required, or who were disgruntled by broken promises of support from their LPG on these matters. ${ }^{56} \mathrm{It}$ might well be argued that the pride farming families had felt in private ownership of land was sought now to some extent in home ownership.

This sense of pride was further reinvigorated by new encouragement for villagers to farm small plots and keep a small number of animals privately. Since the 2nd Plenary Session of the ZK in 1976, overzealous attempts by managers of crop farms to limit the extent of household plots and small allotments were criticised. Collective farmers were encouraged to claim and make use of their right to an individuelle Hauswirtschaft. Ideologically speaking, this re-emphasis on private ownership was a retrograde step for the SED regime. The social transformation of the countryside in the last twenty years had, after all, been aimed at diminishing the importance of private property. This step did, however, serve an immediate practical purpose. Under the conditions of Honecker's 'actually existing socialism' encouragement of private property provided some valuable solutions to food supply and housing problems, as well as improving the morale of the proportion of the rural population who were able to take advantage. Nevertheless new grounds for obvious disparity between the prosperity of individual citizens had been created - between those who had connections and those who lacked them. Ultimately, the shortages of building materials and other resources, which proved to be more frequent in the 1980s, came to represent a major source of disgruntlement among the rural population.

During the 1970s agricultural production reached new heights. Technologically it had never been so advanced and the prospects for further improvement appeared to be good. New machinery and methods for crop production and the construction of high-tech production sites for concentrated livestock farming promised to improve efficiency as well as reduce the level of manual labour required in the future. At the same time, the benefits of Honecker's new welfare- and consumer-orientated social and economic policy filtered through to the rural population, who were able increasingly not only to build their own houses but to have access to their own cars, televisions, radios, fridges and washing machines. But these improvements to living and working conditions were not experienced universally.

By the late 1970s, those villages that had failed to benefit from the industrialisation of agriculture were beginning to suffer from spiralling neglect. With an ageing population, deprived of investment and with only limited access to the materials, goods and services required to im- 
prove their standard of living, the prospects for some rural communities looked bleak indeed. At the same time, it had become clear that the industrialisation of agriculture had in practice generated serious disparities between LPGs in terms of their financial solvency and the conditions in which farmers worked. Huge efforts continued to be made by farmers and LPG functionaries to maintain standards, despite shortages of essential resources (of machinery, fuel, feed grain). However, in an increasingly unfavourable economic climate, the organisation of farming created by the SED's agricultural policy increasingly proved itself too fragile and susceptible to the weaknesses of the planned economy at a time of shortage. By the beginning of the 1980s the prospects for an imminent improvement to productivity and, with it, working conditions had largely evaporated in collective farms.

\section{Conclusion}

The second half of the 1970s saw a brave attempt to transform agriculture and rural society half fail and half succeed. There is no doubt that the formation of separate LPG Ps and LPG Ts was a radical step towards advanced and specialised production. However, the inability of the LPG Ps and Ts to function efficiently in the worsening economic climate and shortage economy demonstrated the fragility of this method of agricultural production in the face of wider economic constraints. Furthermore, the failure of LPG Ps and LPG Ts to cooperate with one another and the consequent severe differentiation in the living and working conditions of certain farmers gave the lie to the SED's claims to provide social improvements to all.

In the late 1970s, in the face of such an uneven transformation of agricultural production, DBD members - many of whom occupied positions as mid-level managers in LPG Ts - called for steps to be taken to reinvigorate the cooperative councils. ${ }^{57}$ Two years later, in 1981, the $X$ SED Party Congress saw an attempt to take heed of these concerns. This congress, which was preceded by the death of Gerhard Grüneberg, signalled a realisation that the current direction of agriculture was not conducive to efficient production given the reality of the economic situation in the GDR. Consequently plans were made to scale back the size of some excessively large individual farms and limit the extent of monocultural specialisation where it appeared to be damaging to production. This slight change in course did not arouse much indignation among farmers and LPG leaders, nor was it seized upon as an excuse to abandon separate crop and livestock production (as had occurred in 
1969 at the 10th ZK Plenum). Not only had the proportion of the farming population been reduced and their local coherence and identity as indigenous farmers been negated by modernisation and industrialisation of agriculture, the introduction of industrial labour practices gave them a fundamentally different attitude towards their work and their position in the hierarchy. The most fundamental changes in the position of the farmers with respect to the land, their livestock and their locality had been accepted. Moreover, SED and DBD party organisations in the LPGs were better organised than ever and were able to influence the reception of the X SED Party Congress more effectively. At this stage the ability of the SED leadership to communicate its authority was not seriously in doubt. The seeds of material discontent among the rural population were, however, growing.

\section{Notes}

1. KAS Rat des Kreises Sömmerda 2907 Protokoll über die Vorstandssitzung der LPG Buttstädt am 13.9.1974, 16.9.1974.

2. ThHStAW Bezirksparteiarchiv der SED Erfurt, Bezirksleitung der SED Erfurt IV/C/2/7 - 348 SED Bezirksleitung Abt. Landwirtschaft, Aufstellung der KAP ohne GO, 12.11.1975, p. 2; SED Bezirksleitung Abt. Landwirtschaft, Einschätzungen der Entwicklung der Kampfkraft der GO in den einzelnen Pflanzenbaubetrieben des Kreises, 11.1.1977, p. 6.

3. BArch DK 1 VA neu 2464 Ministerium für LFN, Probleme der Führungstätigkeit im Bereich der Landwirtschaft und Nahrungsgüterwirtschaft im Bezirk Erfurt, 1971 (undated).

4. ThHStAW Bezirksparteiarchiv der SED Erfurt, Bezirksleitung der SED Erfurt IV/C/2/7-344 SED Bezirksleitung Abt. Landwirtschaft Information über die Jahresendversammlung der LPG Kranichfeld, Kr. Weimar am 21.1.1972, 27.1.1972, p. 6.

5. ThHStAW RdB Erfurt L036208 RLN (B) Produktionsleitung für Land- und Nahrungsgüterwirtschaft, Bericht über die Ergebnisse der JHV, JEA 1974 sowie der Betriebsplanung 1975 der VEG, LPG, GPG und ihren kooperativen Einrichtungen, 6.3.1975.

6. SAPMO BArch DY30/1516 ZK der SED Abt. Landwirtschaft, Analyse zu einigen wichtigen Problemen der gesellschaftlichen Entwicklung in der Pflanzen- und Tierproduktion, 21.12.1973, p. 235. In Bezirk Erfurt in particular the KAP Greussen, Kreis Sondershausen, KAP Leubingen, Kreis Sömmerda, KAP Sonneborn, Kreis Gotha and KAP Förtha in Kreis Eisenach were accused of making such premature applications for recategorisation. An additional problem was the breakdown in the use of members' assemblies for all members of the LPG with the establishment of the KAP. As a consequence the principles of collective democracy were seen to be suffering. 
7. SAPMO BArch DY30/IV B 2/2.023/24 Büro Gerhard Grüneberg, Material für die Beratung mit den Sekretären und Abteilungsleitern für Landwirtschaft der Bezirksleitungen am 29.7.1974.

8. ThHStAW Bezirksparteiarchiv der SED Erfurt, Kreisleitung der SED Sömmerda IV/B/4.10/200 GO der SED der 4 LPG der Kooperation Weissensee, Vorlage für das Sekretariat der Kreisleitung und der Bezirksleitung der SED, 26.11.1971, p. 258.

9. SAPMO BArch DY30/IV B 2/5/459 Rat des Bezirkes Erfurt, Information an das Sekretariat der Bezirksleitung über die Bildung von LPG und ZBE (P) und die Zusammenschlüsse von LPG, GPG und KAP mit Beginn des Jahres 1977, 18.10.1976.

10. SAPMO BArch DY30/IV B 2/2.023/33 Büro Gerhard Grüneberg, Bemerkungen in der Beratung bei Genossen Schürer am 24.10.1974.

11. SAPMO BArch DY30/IV B 2/2.023/16 Büro Gerhard Grüneberg, Grüneberg an E. Honecker, 29.11.1974.

12. ThHStAW Bezirksparteiarchiv der SED Erfurt, Kreisleitung der SED Sömmerda IV/C/4.10/183 SED Kreisleitung, Demokratischer Block, Protokoll über die Kreisblocksitzung am 6.2.1975, Referat Genosse Lindenlaub, p. 78.

13. ThHStAW RdB Erfurt L041322 RLN (B) Probleme in Auswertung der Dienstberatung vom 3.2.1975 beim Vorsitzenden des Rat des Bezirkes, 5.2.1975.

14. ThHStAW Bezirksparteiarchiv der SED Erfurt, Kreisleitung der SED Sömmerda IV/C/4.10/183 SED Kreisleitung Demokratischer Block, Protokoll über die Kreisblocksitzung am 6.2.1975, Referat Genosse Lindenlaub, p. 78.

15. ThHStAW Bezirksparteiarchiv der SED Erfurt, Bezirksleitung der SED Erfurt IV/C/2/17-541 Rat des Bezirkes Erfurt, Information an das Sekretariat der Bezirksleitung über die Arbeits und Lebensbedingungen der Genossenschaftsbäuerinnen, die in alten herkömmlichen Ställen der Tierproduktion arbeiten, 5.11.1976, p. 95.

16. ThHStAW Bezirksparteiarchiv der SED Erfurt, Bezirksleitung der SED Erfurt IV/C/2/7-348 SED Bezirksleitung, Abt. Landwirtschaft, Untergliederung der Betriebe der Tierproduktion nach der Anzahl der Beschäftigten, 1.11.1977, p. 66.

17. ThHStAW Bezirksparteiarchiv der SED Erfurt, Bezirksleitung der SED Erfurt IV/C/2/17-541 DBD Bezirksverband, Vorschläge zur Lösung von Entwicklungsproblemen und Aufgaben in der Landwirtschaft des Bezirkes Erfurt, 20.8.1975, p. 101.

18. SAPMO BArch DY30/1705 ZK der SED Abt. Landwirtschaft, SED Bezirksleitung an Genossen Kiesler, 1.12.1976, p. 183.

19. ThHStAW Bezirksparteiarchiv der SED Erfurt, Bezirksleitung der SED Erfurt IV/C/2/7-344 SED Bezirksleitung Abt. Landwirtschaft, Bericht über die Verwirklichung der Beschlüsse des VIII. Parteitages ... Jan. 1976, p. 192.

20. LPG/KAP in hilly Kreis Worbis remained under 3,000 hectares. SAPMO BArch DY30/IV B 2/5/459 Rat des Bezirkes Erfurt, Information an das Sekretariat der Bezirksleitung über die Bildung von LPG und ZBE $(P)$ und die Zusammenschlüsse von LPG, GPG und KAP mit Beginn des Jahres 1977, 18.10.1986.

21. Following the issuance of the new model statutes in 1977, forty-one new LPG Ps were formed from KAPs. Seventy-eight per cent of the chairmen of 
these LPGs had a university and 22 per cent a technical college education. Thirty-one of the forty-one chairmen were also SED members, six DBD, three CDU with only one cadre with no party membership whatsoever. SAPMO DY30/IV B 2/5/479 Rat des Bezirkes Erfurt, Information an das Sekretariat der Bezirksleitung über die Schritte der weiteren gesellschaftlichen Entwicklung von LPG, GPG, KAP und ZBE im Jahre 1978, 17.10.1977.

22. ThHStAW Bezirksparteiarchiv der SED Erfurt, Bezirksleitung der SED Erfurt IV/D/2/7-477 SED Bezirksleitung Abt. Landwirtschaft, Entwurf, Einschätzung des Standes der ökonomischen Massenagitation und -propaganda in der Landwirtschaft im Bezirk, 10.2.1977, p. 20.

23. ThHStAW RdB Erfurt L041292 Wissenschaftlich-technisches Zentrum der Landwirtschaft des Bezirkes Erfurt, Einige Ergebnisse der Produktionstätigkeit der landwirtschaftlichen Betriebe des Bezirkes in den Jahren 1975-1977.

24. SAPMO BArch DY30/1541 ZK der SED Abt. Landwirtschaft, Information zu wichtigen Ergebnissen der sozialistischen Landwirtschaft im Jahre 1979, 15.4.1980, p. 171.

25. SAPMO BArch DY30/IV B 2/5/459 Rat des Bezirkes Erfurt, Information an das Sekretariat der Bezirksleitung über die Bildung von LPG und ZBE (P) und die Zusammenschlüsse von LPG, GPG und KAP mit Beginn des Jahres 1977, 18.10.1986.

26. SAPMO BArch DY30/1541 ZK der SED Abt. Landwirtschaft, Tendenzen, Ergebnisse und Schlussfolgerungen aus den 7 Bezirksanalysen, 24.4.1979, p. 33.

27. SAPMO BArch DY30/IV B 2/2.023/2 Büro Gerhard Grüneberg, Anlage: Entwicklungsprobleme der Landwirtschaft bei der weiteren Durchführung der Beschlüsse des VIII. und IX. Parteitages, 31.10.1979.

28. ThHStAW RdB Erfurt L041292 Fachorgan Land-, Forst- und Nahrungsgüterwirtschaft, Stand und Entwicklung des gesellschaftlichen Arbeitsvermögens in der Land- und Nahrungsgüterwirtschaft des Bezirkes Erfurt, 19.4.1979.

29. SAPMO BArch DY30/IV B 2/2.023/24 Büro Gerhard Grüneberg, ZK der SED Abt. Landwirtschaft, Einschätzung der Eingaben aus der Bevölkerung im II. Quartal 1978, 15.7.1978; SAPMO BArch DY30/IV B 2/2.023/24 Büro Gerhard Grüneberg, LPG P Bösleben an das ZK der SED Abt. Landwirtschaft, 23.11.1978.

30. SAPMO BArch DY30/1541 ZK der SED Abt. Landwirtschaft, Tendenzen, Ergebnisse und Schlussfolgerungen aus den 7 Bezirksanalysen, 24.4.1979, p. 33.

31. In April 1978 Bruno Kiesler - head of the ZK's Agriculture Department wrote to Gerhard Grüneberg complaining about a set of suggestions for the future economic development of agriculture which he had been asked to co-sign by the head of the Department for Planning and Finance in the ZK. These documents, he maintained, contained evaluations of developmental questions in agriculture which were clearly marked by the tendency to contrive to provide evidence that in the development of agriculture too much had been, and was continuing to be, invested, with little positive benefit. Many of these evaluations (which the statistical office as well as other 
institutions had been commissioned to produce), Kiesler suggested, contained consciously false representations and one-sided analyses. He went so far as to repeat the attitude of certain people that 'for a certain amount of time, certain influential people have been systematically conducting a witch-hunt against agriculture and - as they are connected to agriculture against certain people too.' Suggestions primarily to force agriculture to pay higher prices for industrial goods and to create a fund with which to balance out any excessive investment were due to be presented to the secretariat of the $\mathrm{ZK}$ a few days later, with the possible intention to have them agreed upon at a time when, Kiesler suggested, Grüneberg would be absent. SAPMO BArch DY30/IV B 2/2.023/2 Büro Gerhard Grüneberg, Kiesler an Grüneberg, 21.4.1978.

32. SAPMO BArch DY30/IV B 2/2.023/2 Büro Gerhard Grüneberg, 'Einige wichtige Fakten zum Beitrag der Land- und Forstwirtschaft zur Produktion des Nationaleinkommens der DDR', 22.3.1978.

33. SAPMO BArch DY30/IV B 2/2.023/2 Büro Gerhard Grüneberg, Kiesler und Grüneberg an Honecker, 31.10.1979.

34. SAPMO BArch DY30/IV B 2/5/416 ZK der SED Abt. Parteiorgane, Protokoll der Bezirksleitungssitzung Erfurt vom 12.4.1978, Referat von Genossen Brauner, Sekretär der Bezirksleitung.

35. ThHStAW RdB Erfurt L043160 Wissenschaftlich-technisches Zentrum Erfurt, Leistungsvergleich der Kreise des Bezirkes Erfurt im Zeitraum der 5Jahrplanes 1976-1980 und insbesondere der Jahre 1979 und 1980 II. Quartal 1980.

36. SAPMO BArch DY30/1541 ZK der SED Abt. Landwirtschaft, Tendenzen, Ergebnisse und Schlussfolgerung aus den 7 Bezirksanalysen, 24.4.1979, p. 33.

37. SAPMO BArch DY30/IV B 2/5/416 ZK der SED Abt. Parteiorgane, Protokoll der Bezirksleitungssitzung Erfurt vom 12.4.1978, Referat von Genossen Brauner, Sekretär der Bezirksleitung.

38. ThHStAW Bezirksparteiarchiv der SED Erfurt, Bezirksleitung der SED Erfurt IV/D/2/7-800 SED Bezirksleitung Abt. Landwirtschaft, Information über die MV der BPO der Bezirksdirektion der Bank für Landwirtschaft und Nahrungsgüterwirtschaft am 19.11.1979, p. 355.

39. SAPMO BArch DY30/IV B 2/2.023/1 Büro Gerhard Grüneberg, ZK der SED Abt. Landwirtschaft, Aufgaben der Land-, Forst- und Nahrungsgüterwirtschaft und die weitere gesellschaftliche Entwicklung auf dem Lande, 25.5.1976.

40. SAPMO BArch DY30/IV B 2/2.023/24 Büro Gerhard Grüneberg, ZK der SED Abt. Landwirtschaft, Einschätzung der Eingaben aus der Bevölkerung im IV. Quartal und im Jahre 1976 insgesamt, 20.1.1977.

41. ThHStAW Bezirksparteiarchiv der SED Erfurt, Bezirksleitung der SED Erfurt IV/D/2/9.01 SED Bezirksleitung Abt. Parteiorgane Informationsbericht Nr. 22/77, 28.7.1977, p. 54.

42. SAPMO BArch DY30 IV B 2/2.023/24 Büro Gerhard Grüneberg, ZK der SED Abt. Landwirtschaft, Einschätzung der Eingaben aus der Bevölkerung im IV. Quartal und im Jahre 1977 insgesamt, 13.1.1978. 
43. SAPMO BArch DY30/1540 Rat des Bezirkes Erfurt, Stellvetreter des Vorsitzenden für Land-, Forst- und Nahrungsgüterwirtschaft, Information über die Entwicklung der Landwirtschaft seit 1970, dabei auftretende Probleme und Schlussfolgerungen, 3.10.1978.

44. SAPMO BArch DY30/IV B 2/5/479 Rat des Bezirkes Erfurt, Vorlage an das Sekretariat der Bezirksleitung über die Konzeption zur Durchführung der JHV in LPG, GPG, VEG und ihren kooperativen Einrichtungen, 13.10.1977.

45. ThHStAW Bezirksparteiarchiv der SED Erfurt, Kreisleitung der SED Sömmerda IV/D/4.10/149 SED Kreisleitung Abt. Parteiorgane, Bericht über Ergebnisse der JHV in den LPG und Erfahrungen bei der Anwendung der neuen Musterstatute der LPG, 9.2.1978, pp. 18-21.

46. SAPMO BArch DY30/IV B 2/2.023/61 Büro Gerhard Grüneberg, Komitee der ABI, Information über Kontrollergebnisse zur Entwicklung der Tierverluste in der Rinder- und Schweinehaltung, 21.11.1978.

47. SAPMO BArch DY30/1610 ZK der SED Abt. Landwirtschaft, Genosse Lindner an Genosse Kiesler, Information über Anträge von Genossenschaftsmitgliedern auf Austritt aus LPG, 9.1.1978, p. 54.

48. SAPMO BArch DY30/1469 ZK der SED Abt. Landwirtschaft, Erste Zusammenfassung der Mitgliederbewegung in LPG 1979, 30.1.1980, p. 180.

49. SAPMO BArch DY30/1541 ZK der SED Abt. Landwirtschaft, Tendenzen, Ergebnisse und Schlussfolgerung aus den 7 Bezirksanalysen, 24.4.1979, p. 33.

50. ThHStAW Bezirksparteiarchiv der SED Erfurt, Bezirksleitung der SED Erfurt Nr. 493 SED Kreisleitung Erfurt, Beschluss des Sekretariates vom 23.11.1979, Nr. 372, 13.11.1979, p. 13.

51. KAS Rat des Kreises Erfurt 1451 Protokoll über die Kooperationsratssitzung, Kooperation Walschleben am 18.11.1976.

52. KAS Rat des Kreises Erfurt 1451 Protokoll der KOR Sitzung Pflanzen- TierProduktion vom 22.5.1979.

53. SAPMO BArch DY60/2958 DBD Bezirksvorstand, Abt. Parteiorgane, Ergänzender Abschlussbericht über die Arbeit unserer Partei in Vorbereitung und Durchführung der Wahlen am 14.11.1971, 17.11.1971.

54. ThHStAW Bezirksparteiarchiv der SED Erfurt, Kreisleitung der SED Sömmerda IV/B/4.10/149 SED Kreisleitung Abt. Landwirtschaft, Melkeraussprache in der LPG Weissensee, p. 146.

55. ThHStAW RdB Erfurt L014597 Bürgermeister der Gemeinde Gernrode, Kreis Worbis, an den RLN (K), Einschätzung der Gemeinde, 3.6.1971.

56. ThHStAW Bezirksparteiarchiv der SED Erfurt, Kreisleitung der SED Sömmerda IV/D/4.10/150 SED Kreisleitung Abt. Parteiorgane, Bericht über die Arbeit der Kreisleitung auf der Grundlage des Beschlusses des ZK vom 7.11.1978, pp. 21-35.

57. ThHStAW Bezirksparteiarchiv der SED Erfurt, Bezirksleitung der SED Erfurt IV/D/2/15-575 DBD Bezirksverband an die Bezirksleitung, 30.1.1979, p. 83. 


\section{엉 9}

\section{Economic Crisis and Popular DisSATISFACTION - THE ROAD TO 1989}

The 1980s began with a more self-critical attitude in the SED hierarchy concerning the previous course of agricultural policy. The death of Gerhard Grüneberg, who had played such a dominant role in shaping the direction of SED agricultural policy over the last twenty years, allowed some room for manoeuvre. The arrival of his replacement in the SED leadership, Werner Felfe, along with the new course set during the $\mathrm{X}$ SED Party Congress, promised some retreat from the worst excesses of the gigantism and overspecialisation of the previous five or so years. Importantly, too, new efforts to ensure that crop and livestock production were better coordinated seemed likely. Attempts to scale back the separation of crop and livestock production and price reforms certainly went some way to restoring the finances of farms on paper. However, it proved too little, too late. The financial burden on agriculture continued to be severe throughout the 1980s, limiting the extent of improvement possible in those farms that had so far been neglected in terms of investment, and seriously handicapping those industrialised farms that relied on fuel, fertiliser and machinery in plentiful supply. Not only did all LPGs find it increasingly difficult to maintain standards of productivity, there was also no foreseeable solution to the problems of running agriculture productively and efficiently given the GDR's economic problems. The conditions under which collective farmers had to live and work became increasingly fraught by difficulty and shortage. The worsening economic crisis which the GDR was facing by the mid- to late 1980s thus took a heavy toll on agriculture as well as rural society more broadly.

\section{Popular Dissatisfaction: Pollution, Shortage and Neglect in Rural Society}

By the late 1980s sustained shortfalls in investment across the economy were having a serious impact on living conditions in rural communi- 
ties. Since the completion of collectivisation rural communities had undergone considerable changes. Particularly during the course of the 1970s, the industrialisation of agriculture had had a direct impact on the pattern of rural settlement, elevating the status of some villages while relegating others. The negative impacts of this process on rural communities were mitigated to some extent by improvements (or the promise of them in the near future) to the standard of living possible in other respects. The distance from the home to the workplace may have increased considerably and the status of the individual farmer within the collective farm might have been diminished; but increased incomes and access to a range of modern conveniences in the home were welcome improvements to the standard of living.

However, those villages that did not become centres of the newly industrialised agriculture were often left behind in the distribution of resources for the improvement of public amenities - transport and road networks, water and electricity supplies. By the 1980s the seriousness of the economic problems facing the GDR limited the potential for making up for this neglect. Popular dissatisfaction at, for example, the lack of a consistent running water supply was aggravated still further by new shortages in the supply of essential goods to villages - which again necessarily were less well supplied than towns. The extent of environmental pollution which had come with the (often incomplete or mismanaged) industrialisation of agriculture and the spread of industry (from 1980 brown coal-fired) into the countryside had a damaging effect on the health of the population as well as the reputation of the SED regime. By the late 1980s there was not only considerable disparity in the working conditions in different sites of agricultural production, there was also considerable disparity in the living conditions in rural communities. Worse still, perhaps, there appeared to be no immediate potential for improving the situation, as general economic decline and environmental pollution continued to worsen.

Environmental issues were central to the complaints of villagers about deteriorating living and working conditions. Complaints arising from the overexpansion of fields and the overuse of chemical fertiliser had been made sporadically since the 1960s, while concentrated livestock holdings had long been a source of irritation to those who lived close to them. As early as 1968 there was some anxiety that the land improvement schemes, which were developed as part of the drive towards a large-scale field system, threatened at the same time to undermine the ecology of the land. According to reports on the SED members' assemblies in the party organisations of the LPGs in Kreis Sömmerda, where land improvements were underway in February 1969, there were con- 
tinual complaints from members that trees were being cut down but no new trees were being planted elsewhere. This, they claimed, would lead to a 'steppe-ification' of the countryside and would in the long run be damaging to agriculture. ${ }^{1}$

A report by the Workers' and Farmers' Inspectorate on the state of the villages and farms of Bezirk Erfurt in April 1969 described poor conditions in a surprisingly high percentage of cases. In over half the villages in the Bezirk evidence was found of uncontrolled contamination of the water supply with muck or seepage from the silos. In Kreis Worbis this had led in a number of cases to contamination of swimming pools. Forty-four per cent of farms in the Bezirk were found on investigation to be unclean and disorderly in the vicinity of livestock holdings. Amenities for those working with livestock were also found to be lacking or inadequate in a large proportion of farms. Forty per cent of farms, for example, had no washrooms near the livestock sheds. ${ }^{2}$ The regularity of such complaints increased considerably, however, as a result of the expansion of industrialised farming during the 1970s. The failure to deal with the negative side-effects efficiently was then seriously compounded by a shortage of resources in the 1980s.

An essential question for rural communities throughout the latter part of the GDR's existence was the development of sewage removal and water supply systems. The development of internal plumbing in village houses was a sign of progress, with the proportion of homes with inside toilets marked in SED propaganda as a sign of the benefits of socialism. The issue of water supply and sewage, however, was fraught in the East German countryside as it was in rural communities throughout much of Europe. The connection of small communities to larger networks could not often be easily justified by the cost and the difficulty of doing so, particularly in a shortage economy. However, the need for a regularised system was becoming increasingly pressing with the development of industrial agriculture, which itself required an efficient water supply but also had the tendency in rural areas to pollute the drinking water from natural springs on which many villages relied. From the 1960s onwards considerable progress was made in the connection of rural households to a central water supply. Nonetheless the progress was again by no means comprehensive or universal and became a cause of considerable dissatisfaction in those communities which were neglected or suffered the consequences of contamination by agro-industrial production sites.

The problem of disposal of slurry caused particular difficulties for several of the livestock farms in Kreis Worbis, leading to mistakes with regard to where it was dispersed. In one case slurry from the LPG Teis- 
tungen in July 1988 was mistakenly deposited on meadowland near the village of Jützenbach, leading to an Eingabe from an outraged villager because the smell had caused a number of children to be violently sick. ${ }^{3}$ In 1979 and 1980 a number of Eingaben were written from around the Bezirk complaining about the deliberate piping of slurry into rivers and lakes by LPG Ts, which lacked alternative solutions for disposing of their waste products. Although occasionally fines were imposed for such actions, the balance between economic necessity and the rhetoric of environmental protection were clearly heavily skewed in the former's favour. ${ }^{4}$ These complaints tallied with an analysis of the Eingaben dealt with by the Rat des Bezirkes' deputy for the environment and water in the Bezirk. Apart from a slight increase during the dry year of 1976, the number of complaints had remained stable between 1974 and 1980. The year 1981 saw the number of Eingaben in this area of government doubled and then trebled in 1982. ${ }^{5}$

By 1988 the level of connection to a central water supply was supposed to be 98 per cent across the Bezirk. However, in Kreis ErfurtLand more than 10 per cent of the population remained unconnected despite many years of complaint and lobbying for improvements to be made. A report in October 1988 mentioned 'serious' discussions in public meetings in thirty villages in the district on the continued lack of a constant supply of drinking water, which compounded dissatisfaction at problems with the supply of basic foodstuffs in villages such as meat, bread and dairy products. ${ }^{6}$ In Kreis Arnstadt, where the district could boast a 99.7 per cent connection rate to a water supply, a number of villages continued to complain about the quality of the drinking water with which they were supplied. ${ }^{7}$ A report by the Rat des Bezirkes' representative for the environment and water management in Kreis Apolda noted that despite 99.1 per cent of the district being connected to a central supply of water, drinking water remained unsuitable for small children. Babies were to be supplied strictly with bottled carbonated water only. ${ }^{8}$

The negative consequences of agricultural transformation were felt broadly across rural settlements. The mistakes of overexpansion in agriculture and the breakdown in cooperation between crop and livestock production in the late 1970s, compounded by increasingly severe economic problems facing the GDR as a whole in the 1980s, served only to exacerbate popular dissatisfaction. Rural settlements were in many respects far worse hit than towns, receiving a lower priority in the provision and supply of a whole range of goods and materials which were considered by many basic essentials (rather than luxuries) of an adequate living standard. 
There was some understanding for these shortages. Villagers did not expect to be able to purchase everything from the local shops. It was obvious too that the cost of supplying a few houses with running water or improving local roads or transport networks could not be always be covered immediately and that money would have to be collected locally. It was recognised by many, too, that those who lived in rural communities were often able to benefit from privately owned land and livestock and were able also to take advantage of the LPG's support to construct their own houses and carry out improvements to their communities. Nonetheless access to such benefits was limited and the standard of living in other respects still left much to be desired.

In 1978 a report on the quality of supply in Sömmerda district noted an unsurprising though important fact for rural communities: namely that the smaller the community the worse the provision of goods. Thus those villages with less than 800 inhabitants tended to have the worst level of plan fulfilment for supply. The report concluded: 'all in all the opinion and attitude of the people with regard to supply is not the best. Above all there is a lack of understanding for the fact that certain products are only being offered in the Bezirk and Kreis capitals. ${ }^{\prime 9}$ This situation was made particularly clear during the cold snap of the winter of 1978 to 1979, which saw several villages in Kreis Sömmerda not being supplied with beer for weeks on end. ${ }^{10}$ In the 1980s shortages of consumer goods in rural shops became a more frequent occurrence, making more frequent trips to the towns an unwelcome and time-consuming necessity.

'Customers', it was reported in March 1983 by the SED Kreisleitung, Sömmerda, 'are abusive towards the sales' girls because those whose wishes cannot be fulfilled accuse the staff of wrong doing. These are above all customers from the villages for whom the purchase of certain household goods is barely possible at all anymore.' These issues, as well as the ongoing shortage of protective work clothing, had begun to become a regular topic of discussion in assemblies of LPG members. The report writer put the blame for the lack of supplies (with perhaps a hint of ironic detachment) on the 'rationalisation measures in bulk trade', which had led to 'the range and number of goods on offer in towns and villages continually worsening.' The concentration of shopping facilities in urban and industrial centres had also led to the closure of many rural shops whose range of goods and level of turnover no longer justified their existence. 'The rural population', the report concluded, 'is very irritated by this.' Over the following months the lack of a number of popular cigarette brands led to questions being asked in assemblies of LPG members and the lack of availability of non-alcoholic (!) drinks in the villages owing to transport problems was a cause of further complaint. ${ }^{11}$ 
The problems of access to certain goods presented here were compounded by the belief that prices were rising beyond the capacity of certain sections of the community to pay for them. Reports from the DBD organisations in Bezirk Erfurt recorded some popular acclaim for new measures introduced to improve conditions for vulnerable members of the population in the mid-1980s. Increases in the net incomes of families with more than three children, and of pensioners, were welcomed; however, it was also felt that these measures should have been taken earlier. The increasing prices demanded for certain goods had long made themselves felt, it was argued, not least because they were often no longer available in the standard Konsum shops but were only on sale at an inflated price in the luxury Delikat shops. ${ }^{12}$

The sense of rural neglect was added to still further by the failure of simple improvements to be made to what many people now considered basic infrastructure throughout the Bezirk. In public meetings in Kreis Apolda the lack of road building was a common source of criticism voiced by villagers, as was the ever-worsening provision of transport for workers. In Niederroslar the comment was made that: 'the workers get driven to work alright, but whether they ever get home, doesn't bother anyone'. In Sonnendorf, Kreis Bad Langensalza a number of complaints were made by villagers, that theirs was a 'forgotten village', owing not least to the lack of improvement to the access road, the lack of bus transport and the lack of repairs carried out to the path to the school in Grossheringen. On these issues, however, as well as the longstanding supply problems to the village, the inhabitants had reportedly ceased to expect much improvement. ${ }^{13}$ Similar feelings of resignation were expressed in the village of Friedrichsrode in Kreis Sondershausen, where the lack of transport connections and the lack of work other than in the turkey farm of the LPG T Immenrode had led to rapid depopulation. All previous Eingaben had failed to have an impact, as there was simply not enough economic justification for investment to transform the prospects of this rural community. ${ }^{14}$

The rhetoric of progress espoused by the SED leadership consistently throughout the 1960s and 1970s as justification for the radical transformation of conditions in the countryside, with the collectivisation and subsequent industrialisation of agriculture, had burdened functionaries in the LPGs and the district party and state administration by the 1980s with great expectations of improvement among collective farmers and villagers more generally. Their consistent failure to provide the promised improvements to quality of life in some rural communities, along with ever more critical working conditions in the LPGs, rendered the SED regime's claims to legitimate authority increasingly hollow. The majority of farmers were earning considerably better money than 
they had ever done before; however, there was little to spend it on and little prospect of actual improvement to either living or working conditions as the basic financial bankruptcy of the GDR under the present SED leadership became ever more tangible.

\section{Agricultural Reform}

In 1981 the future did not look good for agriculture in Bezirk Erfurt as in the rest of the GDR. In September that year the agriculture department at the ZK received with dismay the latest demands of the State Planning Commission for a further reduction in the levels of grain imports into the GDR above and beyond the previous target. The SPK intended that, by 1985, instead of the 3.1 million tonnes of grain previously planned, only 0.5 million tonnes would be imported. As a consequence the amount of grain available for livestock feed from domestic production as well as imports was expected to sink. Alongside this quantitative reduction, it was also expected that there would be a qualitative reduction in the feed available with the purchase of cheaper, less nourishing varieties. Under these conditions it seemed unavoidable that the level of meat and dairy production would have to be scaled back considerably, with consequences not only for farmers but also for the supply of certain foods to the domestic population. There was an obvious agenda in the agricultural department's presentation of a worse-case scenario. No department relished the prospect of cuts to the budget it was allocated. Nevertheless, a drop in grain imports was certain to have a far-reaching social and economic effect.

Given such grain shortages, it made sense to allocate resources to those farms that produced most efficiently at the expense of other, less efficient production sites. However, it was not entirely clear which of the GDR's farms were the most efficient producers. In theory, the modern concentrated production facilities were the most productive. This, however, did not always prove to be the case in practice, given their fuel consumption and problems with disease as well as waste disposal. Closing or reducing the capacity of such facilities was tantamount to a public admission of economic crisis and implied that the SED policy of industrialisation of agriculture had, as many farmers had predicted, been at best mis-implemented, if not fundamentally ill-conceived. Continuing to supply them at the expense of other smaller LPG Ts, which had been denied the chance to develop but had nonetheless maintained production levels, was potentially counterproductive and was bound to anger the farming population. The ideology of progress on which 
socialist agriculture and socialist ideals of rural development had been built and justified to the rural population was thus seriously under threat from the dire economic straits in which the GDR was increasingly finding itself from the early 1980s onwards. ${ }^{15}$

At the start of 1982 there was an increasingly clear imbalance between the financial solvency of the LPG Ps compared with that of the LPG Ts. Eleven times as many livestock farms as crop farms were found to be struggling to maintain production levels. Given that livestock farms were dependent on the crop farms for their ability to produce effectively, there was a clear issue of cooperation to be addressed. ${ }^{16}$ In the face of this imbalance and with the prospect of a reduction in imported feed supplies, there was strong support within the state and party apparatus as well as amongst farmers for a return to a more traditional, symbiotic style of relationship between crop and livestock production. As early as February 1980 a Politburo resolution had been published in the Neue Deutsche Bauernzeitung (The New German Farmers' Newspaper), calling upon LPGs to form cooperative councils to coordinate relations between crop and livestock production. This call was reiterated during the X SED Party Congress in 1981. An analysis of the district farmers' conferences held in 1982 prior to the XII German Farmers' Congress noted widespread support for attempts to strengthen cooperative councils. Farmers were clearly motivated by the realisation that the mutually (if not equally) dependent relationship between crop and livestock production needed to be better managed. ${ }^{17}$ Reports on the situation in agriculture in the various districts of the Bezirk referred again and again to the damage done to LPG Ts by the irregularity in the yields and delivery of fodder by the LPG Ps. ${ }^{18}$

Following the XII German Farmers' Congress (13-14 May 1982) and the promulgation of a new LPG Law in 1982 giving a clear legal basis for cooperation between LPG Ts and LPG Ps, effective action was taken to organise cooperative councils containing delegates from LPG Ps and one or more of their neighbouring LPG Ts. The composition of the reestablished cooperative communities in many respects reflected partnerships of previous standing between LPGs and KAPs, although this was not always the case given the pattern of mergers over the previous few years.

The tasks of the cooperative council and the central elements of the cooperation between the LPGs were laid out according to a clearly defined and largely uniform pattern. ${ }^{19}$ The effectiveness of the actual cooperative relations between LPG Ps and LPG Ts varied, however. In theory the contracts drawn up to regulate the cost, quantity, quality and delivery of feed which the LPG Ps were to provide livestock farms were 
binding. In practice, however, recourse to the courts to claim restitution for breach of contract was unheard of. The settlement of disputes came down in no small part to the relative strength, characters and connections of LPG chairmen in their respective LPGs.

How well the cooperation functioned and competition between LPGs was managed depended to a large extent, therefore, on the abilities of the honorary chairman of the cooperative council. The KOR chairman was usually one of the heads of the constituent farms and remained in his position usually for a period of three years or until he was deemed no longer able to cope with his workload. As the state administration devolved considerable powers on to the KORs to coordinate the economic and social development of rural communities within the cooperation, the significance of the KOR chairman increased. Unsurprisingly perhaps, this development provoked new discussion of the problems of the separation of crop and livestock production. In DBD members' assemblies in Bezirk Erfurt, farmers now asked hopefully whether the LPG Ps and Ts would in practice be merged together again. ${ }^{20}$

In essence the Politburo resolution entailed the transfer of a range of powers to the cooperative council to enable it actively to plan and coordinate agricultural production by the various farms within the cooperative over an extended period of time. Without actually cancelling the separation of crop and livestock production, the enhanced standing given to the cooperative councils also enabled cooperating LPG Ps and LPG Ts to be regarded for administrative purposes as single entities. The acquisition of these extended powers and enhanced status took place gradually, however. Only by the start of 1986 were all farms within the purview of a newly empowered KOR. Extending the powers of these councils was intended to enable in future more effective use of funds with which to develop production facilities and organise recruitment and qualification measures territorially. As before, however, the extent to which KORs fulfilled fully the additional administrative tasks required of them varied considerably. ${ }^{21}$ Despite the efforts of the SED leadership to recreate the administration of a coordinated crop and livestock production, fundamental imbalances remained. These imbalances only aggravated the impact of the ever-worsening economic climate on the experience of life and work in agriculture and rural society.

\section{Managing Mis-industrialisation}

The shortage of heavy machinery and spare parts, fertiliser as well as manpower, rendered agriculture on an industrial scale increasingly 
fraught with crisis. No less worrying for farmers was an apparent drop in the fertility of the land in some LPGs, thanks to wind damage over the unbroken expanses of oversized fields and soil exhaustion as a result of intensive monocultural plantations. Together these factors rendered the achievement of consistently good yields almost impossible and in so doing prevented the realisation of one of the primary goals of the socialist transformation of agriculture: namely the achievement of consistency, predictability and thus plan-ability in agricultural production.

A study of the extent of mechanisation in Kreis Eisenach in August 1982 revealed that the LPGs had reached the limit beyond which any further reduction of the workforce would have a serious negative impact on the ability of farmers to maintain agro-technical deadlines. At the same time, it was noted that measures to prevent further erosion of the soil in large parts of the district were urgently required. ${ }^{22}$ Ongoing plan shortfalls along with 'unjustified' variation in yields between similarly situated districts in Bezirk Erfurt also continued to be reported in $1983 .{ }^{23}$ If yields were inconsistent this could only have a negative impact on livestock production. In Bezirk Erfurt there had been a drop in the gross turn over in livestock production between 1980 and 1983, with a notable decrease, for example, in the quantity of milk produced per cow. In 1982 seventy livestock farms had herds producing no more than 2,500 kg per cow, a figure embarrassingly low considering that $3,000 \mathrm{~kg}$ had been considered an attainable target at the start of the 1960s. ${ }^{24}$

Shortages of fuel were becoming increasingly problematic for agriculture during the course of the 1980s. This was in small part because the quantity of fuel allowed the LPGs was often spent on carrying out other tasks within the local community (such as rubbish collection or road repairs). More seriously, however, the fuel requirements for transport of manpower as well as crops had been increased considerably, exacerbated by a non- territorial organisation of production, and were now unsustainable given the price of oil. ${ }^{25}$ With growing uncertainty about how to sustain industrial-style agriculture at a reduced cost and with reduced inputs of key raw materials - in particular fuel - new consideration was given to the optimum organisation of crop production. Plantation sizes had reached averages of over 50 hectares for grain, 40 hectares for potatoes and 57 hectares for sugar beet in the GDR as a whole. In some parts of the GDR, plantations had expanded to as much as 250 hectares. Opinion was growing, however, that such expanses were not sustainable in practice and indeed could have a deleterious effect on productivity. ${ }^{26}$ 
Moreover, there was growing concern that productivity was being compromised by the lack of personal connection and responsibility felt by the LPG farmer with regard to the land he now worked on. It was argued that the fields should be of a reasonable size to allow those working on them to develop a sense of responsibility for the soil and the yield produced there. This was, of course, not simply a question of the size of the fields but how the farmer was deployed to work on them. LPG Ps had long been encouraged to increase the number of LPG members organised in brigades with specific skills or specific technical responsibilities, rather than with specific territories. ${ }^{27}$ Brigades located in and responsible for a particular territory within an LPG now seemed far more preferable. Having greater local knowledge of the land and the range of work which could be done on it at any given time of the year enabled such brigades to respond to sudden shortages or crises at short notice, reducing down-time caused by delays beyond their immediate control. Arguably, too, the reinvigoration of local pride associated with territorial brigades gave added incentive to farmers to devote themselves to improving production.

\section{Mis-industrialisation or Sabotage?}

The seriousness with which the SED leadership were taking the problems of East German agriculture can be seen in the renewed interest shown by the Ministry for State Security in the LPGs during the early 1980s. In August 1983 a report on the situation in agriculture in Bezirk Erfurt by the head of the responsible department in the Bezirk administration of the Stasi called for plans to be made to counter suspected economic sabotage in the LPGs. ${ }^{28}$ Judging by the list of recommendations for improvements to the work of the Stasi necessary in future, the extent of operations in agriculture had up to this point been greatly limited. This was arguably because of the lack of flashpoints of overt hostility to SED policy in the sphere of agriculture during the later 1970s, since the transition to separate large-scale crop production had effectively ended the existence of the remaining Type I LPGs.

In the Stasi's district administrations the staff responsible for agriculture tended to be responsible for general matters for the whole rural area, with the result that the networks of informers already recruited were not necessarily well focused on centres of agricultural production. In 1983, in a number of industrial livestock production facilities such as the major pork production centre in Neumark, Kreis Weimar not a single informant ('Inoffizieller Mitarbeiter' or IM) was fully opera- 
tional. Quality of information gathering and reporting varied across the Bezirk. While the Stasi administrations in Kreis Weimar and Kreis Gotha were praised for being effective at organising cells of informers to infiltrate agriculture, in Kreis Nordhausen and Heiligenstadt no such cell had been formed. The district Stasi offices in Heiligenstadt, along with those in Apolda, Eisenach and Erfurt, were also criticised for failing to provide sufficient information to the Bezirk authority on agricultural affairs.

In order to rectify the situation, IM and so-called 'security deputies' in key positions in the administration of agriculture and the collective farms were to be recruited. These recruits were to keep a look-out in particular for evidence of illegal activity among LPG managers. The district administrations in Worbis, Bad Langensalza and Sömmerda had all already begun investigations into leading functionaries in a number of LPGs for a variety of reasons. Reports of 'negative comments about socialist agricultural policy' and active contacts in the West naturally provoked suspicion. However, serious investigations were also pursued against those who were thought to be maintaining too many private livestock or to be involved in 'criminal trade, above all in stolen livestock feed'. 'Official and unofficial information' collated by the Stasi also caused agricultural functionaries in the state apparatus in a number of districts to come under suspicion for involvement in a similar selection of illegal activities. Ultimately, however, investigations by the Ministry for State Security were most often prompted by obvious economic failure in an LPG.

At this point, while most of the LPG Ps in the Bezirk were able to maintain financial solvency, there were at least thirty LPG Ts considered to be struggling, with low production levels. Such was the prevalence of high rates of livestock mortality among those LPGs which were struggling financially, this was taken to be the consequence of economic sabotage or at least criminal negligence. Premature deaths among livestock were caused on the whole by a lack of sufficient feed and overcrowded and unhygienic living conditions for the animals. In some cases there was undoubtedly some mistreatment of livestock and dereliction of duty by those working in the LPGs. Some LPG Ts were no doubt mismanaged. Nonetheless it was clear that in most struggling LPG Ts, the basic cause for low productivity levels and high mortality rates lay in insufficient financial and material investment over a number of years.

Rather than exposing widespread 'hostile' activity, the Stasi investigation illustrated the extent to which the system for scrutinising and taking action to improve the state of affairs in LPGs had consistently 
failed to have an impact over the course of several years. Officially, agricultural functionaries in the district state apparatus were criticised for failing to take action to find solutions to the dire situation some LPG Ts found themselves in. At the same time, LPG cadres were blamed and in some cases removed from their posts for failing to take action against irresponsible and negligent work by LPG members. It was nevertheless apparent even from the Stasi report that disparity in the performance of LPGs was the consequence of the state's economic inadequacy and long-running prioritisation of resources.

LPG P cadres, too, came in for criticism and suspicion if the amounts of produce their farm made available to the state or the quantity of feed they made available to their neighbouring LPG Ts were considered inadequate. The LPG P Isseroda in Kreis Weimar and the LPG P in Stockhausen Kreis Eisenach were found to be showing particular shortfalls in production. In these cases the heads of the LPG were criticised for mismanaging the farms, though not accused of actual sabotage - in the case of Isseroda low yields were very likely the result of soil exhaustion. There was, however, also suspicion of LPG cadres in general, many of whom were thought to be involved in deliberate misrepresentation of the LPG's actual yields during the harvest, with the intention of building up an unregistered reserve supply of produce. Stocks, particularly of grain, were at a premium in the 1980s, giving LPGs added incentive to seek to keep control of the amounts they gave up and the payment they received for it.

The shortage economy and the half-achieved industrialisation had made it necessary for LPG chairmen to pursue every avenue available to them - including ones which subverted the system - to sustain the levels of profit and production expected of them, by the state on the one hand and the members of the LPGs on the other.

\section{Financial Reform}

At the heart of support for a return to 'joined-up' crop and livestock production was the hope, particularly among farmers in LPG Ts, that working conditions and incomes would be improved as a result. Better relations with the LPG P would bring reduced feed and transport costs and greater financial and material resources with which to develop more efficient, less labour-intensive production facilities. Given the shortage of manpower in agriculture, farmers were already having to perform very high numbers of overtime hours during the late 1970 s and 1980s in order to maintain production. Information collected by the 
Agriculture Department of the ZK on the level of overtime being carried out in LPGs revealed just how different conditions in agriculture were to those in industry.

Responding to a query from the chairman of the LPG P Gamstädt, Kreis Erfurt-Land, the ZK Agriculture Department noted that in 1980 more than 250 extra hours per fully employed member of the production personnel were being carried out on average in LPGs in the GDR each year. In the LPG Ts the average was considerably higher at 317 hours. This compared unfavourably with workers in industry who performed on average only fifty-seven hours of overtime a year. Thus while each person working in agriculture earned only slightly less than an industrial worker in total, they had to do longer hours. On average the income per hour of an agricultural labourer and member of the LPGs remained at only 88 per cent of that of an industrial worker. ${ }^{29}$ As a further reduction of the agricultural workforce became increasingly unsustainable as a result of the lack of machinery and spare parts, there was a clear need to make agriculture attractive enough a job prospect to retain sufficient manpower. Given the ongoing gap in the incomes of farmers and industrial workers, this was a clear area for possible improvement.

In resolutions made by the Politburo in October and then by the Ministerial Council in November 1982, the intention to carry out a price reform in two years' time largely to the benefit of agriculture had been settled, predominantly in response to the ever-worsening balance between costs and gross production in collective farms across the GDR. Until the price reforms came into effect, in Bezirk Erfurt thirty-one LPG Ps and eighty-nine LPG Ts were not expected to be able to reduce their costs without scaling back production. Indeed a number of LPG Ts were expected to sustain severe financial losses of several hundred thousand Marks. ${ }^{30}$

The price reform, it was hoped, would explicitly appeal to 'good farming traditions of clever calculation'. Moreover, it was intended to put a 'more correct' value on agricultural production in the GDR and in so doing increase the income of the individual farmer. ${ }^{31}$ The report by the Rat des Bezirkes on the consequences of the 1984 price reforms for the SED Bezirksleitung in Erfurt predicted considerable improvements in the financial stability of the LPGs. The monetary increase in value of the gross product of LPGs in the plans for 1984 would - after the reforms - far outstrip increases in costs. This in turn was expected to be reflected in the level of personal income per full-time member of the agricultural workforce, which would rise to a planned level of over 10,000 Marks in both crop and livestock farms. The expectation was that there would no longer be any LPGs operating at a loss. ${ }^{32}$ This expectation 
appears to have been borne out. A report on the state of the finances of the LPGs in the Bezirk in 1988 pointed out that the number of LPG Ts that were counted among those with a low production level had been reduced since the early 1980s, and only two LPG Ts were found to be operating at a loss. This rebalancing of the figures could, however, only have limited immediate impact on the quality of working conditions in agriculture. ${ }^{33}$

Despite the apparent skew in favour of agriculture the new prices were also designed to accommodate changes in industrial prices, which would eventually increase costs to the LPGs. ${ }^{34}$ Moreover, although the price reform in theory would enable LPGs to be able to afford to pay for machinery, fertiliser and fuel which they so badly needed, and maintain the incomes of the farmers at the levels now expected, there was no guarantee that these resources would be available to purchase. A report on the members' assemblies of the DBD in July 1984 suggested that despite the price reforms farmers were sceptical of the possibilities for increased production given the actually reduced amount of fuel, materials and spare parts available. ${ }^{35}$

Throughout the late 1980s farmers complained of shortages of vital machinery and equipment. At the district farmers' conferences in 1985 there were widespread complaints about a lack of sufficient machinery for use in the harvest of nearly all main crops, for use in livestock sheds, as well as in the transport and loading and unloading of produce. Shortages of protective clothing, of spare parts, tyres, fertiliser and pesticides were all cause for complaint as well. The situation had become so severe, farmers argued, that even with the greatest care and continual repair of the machinery available it was impossible to harvest within agro-technical deadlines. Regardless of the quality of the yield that year, losses of produce were therefore bound to occur. ${ }^{36}$

One of the other impacts of the price reform was to encourage private production. ${ }^{37}$ Information from the Ministerial Council on the effects of the price reform in May 1984 noted above all a positive impact on individual - i.e. private - production, with a rise in profits in this branch of agriculture. ${ }^{38}$ By 1989, in the GDR as a whole, household plots and livestock accounted for 34 per cent of eggs, 15 per cent of animals for slaughter, 22 per cent of fruit and 14 per cent of vegetables supplied to the state. ${ }^{39}$ The price reforms thus succeeded in encouraging a considerable increase in private entrepreneurship in rural communities. Although this was a practical solution to the GDR's various problems of production, it was nonetheless another ideologically retrograde step. Moreover, it added to the disparities of wealth between individuals and families within a community, who were either more or less capable 
of exploiting their political and social connections to gain access to resources. Honecker's brand of socialism appeared to be working against, not for, social equality.

Despite the formation of the KORs and the price reforms, agriculture in the Bezirk as in the country as a whole was still racked with conflict and crisis. The economic performance of LPG Ts remained precarious (even after the price reforms). The worst cases had had long histories of poor production results, having failed to transform the conditions of production over the years..$^{40}$ LPG Ps too continued to vary considerably in productivity. ${ }^{41}$ In spite of the price reforms of 1984 there was still considerable variation in the profitability between LPGs. As the first waves of mass protest began to gather strength in the GDR in September 1989, the Rat des Bezirkes in Erfurt could not paint a rosy picture of the state of collective farming. ${ }^{42}$

\section{Conclusion}

During the autumn of 1989, the proportion of collective farmers who participated in demonstrations showing their open rejection of the SED regime was not recognisably very high. Nonetheless it was clear that the SED leadership was considered morally as well as financially bankrupt in the villages as elsewhere in the GDR. Loyalty remained in many cases to the LPGs and also to LPG functionaries regardless of their party affiliation. In 1989 and 1990, the LPG Ts and the LPG Ps still remained at the heart of village life and, given the enormous lack of certainty about the future, the prospects for the individual remained bound up closely to the prospects for the collective farm to which they belonged. Leading functionaries of LPGs often fought hard to maintain some viable form of large-scale agricultural production in which to employ as many as possible of the members of the LPGs. However, loyalty to the SED regime as a whole evaporated in the countryside as quickly as elsewhere in the GDR. In many villages in Bezirk Erfurt, the church had remained of central importance, particularly to the older generations who continued to make up a large proportion of the village's population. SED membership and DBD membership had certainly become more commonplace among farmers in the thirty years since collectivisation had got underway; however, party groups remained relatively small and weak in comparison to their counterparts in industry. The breakdown of the SED regime was therefore not mourned immediately by many.

This study does not seek to give a full explanation for the collapse of the GDR or the SED regime. If one were to explain all the causes 
of the collapse of the SED regime in 1989, one would not necessarily dwell very long on the problems of agricultural production, the failure to improve living conditions in villages or the crisis conditions in some LPGs. Nonetheless, the growth of popular dissatisfaction with the SED regime and discontent, too, among party members and functionaries of the state administration (as the possibilities for countering the consequences of the worsening economic crisis during the late 1980s diminished) was part of a complex of causes and consequences which prompted the end of the SED dictatorship.

The growth in the extent of popular discontent lent increasing strength to the public calls for change begun by small opposition groups, whose numbers swelled rapidly during the early autumn of 1989. The apparent bankruptcy of the GDR and the withdrawal of Soviet economic and ultimately political support not only prompted popular dissatisfaction and its virulent public expression but also ensured these public demonstrations had a deep impact on the SED leadership. By the time the borders to West Germany were opened there was little prospect of sustaining the GDR's existence. The majority of the population looked now to the West for economic salvation, rejecting the economic failure and social and political control of the SED dictatorship.

\section{Notes}

1. ThHStAW Bezirksparteiarchiv der SED Erfurt, Kreisleitung der SED Sömmerda, IV/B/4.10/101 SED Kreisleitung Abt. Parteiorgane, Einschätzung der MV - Monat Februar, 28.2.1969, p. 127.

2. ThHStAW RdB Erfurt L014785 Arbeiter- und Bauerninpektion Erfurt, Bericht über die Ergebnisse der Massenkontrolle 'Sicherheit, Ordnung und Sauberkeit' in den Gemeinden und sozialistischen Landwirtschaftsbetrieben des Bezirkes Erfurt, 24.4.1969.

3. ThHStAW RdB Erfurt 046350 Rat des Bezirkes, Stellv. des Vorsitzenden für Umwelt ... an den Rat des Kreises Worbis, 21.6.1988; Rat des Kreises Worbis an Herrn B., Jützenbach, 5.7.1988.

4. ThHStAW RdB Erfurt 046467 Oberflussmeisterei Erfurt für das I. Halbjahr 1979, 28.6.1979; Oberflussmeisterei Erfurt, Analyse über die Eingabenarbeit in der Oberflussmeisterei 1979, 6.12.1979; Rat des Kreises Erfurt, Abt. UWE, Eingabenanalyse I. Halbjahr 1980, 14.7.1980; Rat des Kreises Worbis, Abt. UWE I. Halbjahr 1980, 9.7.1980; Rat des Kreises Weimar, Abt. UWE, Eingabenanalyse III. Quartal 1980, 3.10.1980.

5. ThHStAW RdB Erfurt 045464 Rat des Bezirkes, Stellv. des Vorsitzenden für Umwelt ..., an den Ministerrat der DRR, Stellv. des Vorsitzenden und Minister für Umwelt ..., Eingabenanalyse 1982, 4.1.1983.

6. ThHStAW RdB Erfurt 046500 Rat des Bezirkes, 1. Stellv. des Vorsitzenden, Stellungnahme zur Berichterstattung des Rates des Kreises Erfurt-Land in 
Auswertung der Einwohnerforen mit dem Bezirksreferentenkollektiv vom 17.8.1988, 31.10.1988.

7. ThHStAW RdB Erfurt 046502 Rat des Bezirkes, 1. Stellv. des Vorsitzenden, Stellungnahme zur Berichterstattung des Rates des Kreises Arnstadt über die Verbesserung der staatlichen Leitungstätigkeit in Auswertung der Einwohnerforen am 16.11.1988, 27.2.1989.

8. ThHStAW RdB Erfurt 046501 Rat des Bezirkes, Stellv. des Vorsitzenden für Umwelt ..., Einschätzung zur Leitungstätigkeit des Rat des Kreises Apolda im Umweltschutz und in der Wasserwirtschaft, 24.10.1989.

9. ThHStAW Bezirksparteiarchiv der SED Erfurt, Kreisleitung der SED Sömmerda IV/D/4.10/149 SED Kreisleitung Abt. Parteiorgane, Versorgungsinformation, 12.10.1978, p. 107.

10. ThHStAW Bezirksparteiarchiv der SED Erfurt, Kreisleitung der SED Sömmerda IV/D/4.10/150 SED Kreisleitung Abt. Parteiorgane, Versorgungsinformation, 13.2.1979, p. 36.

11. ThHStAW Bezirksparteiarchiv der SED Erfurt, Kreisleitung der SED Sömmerda IV/D/4.10/152 SED Kreisleitung Abt. Parteiorgane, Versorgungsinformation, 16.03.1981, p. 42; Abt. Parteiorgane, Versorgungsinformation, 15.5.1981, p. 63; Abt. Parteiorgane, Versorgungsinformation, 16.6.1981, pp. 66-67.

12. SAPMO BArch DY60/3097 DBD Bezirksverband, Einschätzung der Mitgliederversammlungen im Monat Juli 1984, 9.8.1984.

13. ThHStAW Bezirksparteiarchiv der SED Erfurt, Bezirksleitung der SED Erfurt Nr. 3068, SED Bezirksleitung Abt. Agit./Prop, Einwohnerforen im Kreis Apolda am 29.10.1986, 7.11.1986, p. 8.

14. ThHStAW Bezirksparteiarchiv der SED Erfurt, Bezirksleitung der SED Erfurt Nr. 3068, SED Bezirksleitung Abt. Agit./Prop, Einwohnerforen im Kreis Sondershausen am 24.9.1986, 30.9.1986, p. 22.

15. SAPMO BArch DY30/1512 ZK der SED, Abt. Landwirtschaft, Standpunkt zu den neuen Forderungen der Staatlichen Plankommission, 8.9.1981, p. 299.

16. ThHStAW Bezirksparteiarchiv der SED Erfurt, Bezirksleitung der SED Erfurt Nr. 3865 Ubersichtsstatistik Stand, 1.10.1982.

17. SAPMO BArch DY30/32 Büro Werner Felfe, ZK der SED, Abt. Landwirtschaft, Information über den Verlauf und Ergebnisse der KBK zur Vorbereitung des XII. Bauernkongresses der DDR, 24.2.1982.

18. ThHStAW RdB Erfurt L041357 Rat des Bezirkes Stellvertreter des Vorsitzenden für Land-, Forst- und Nahrungsgüterwirtschaft, Protokoll über die Durchführung des Beschlusses des Rat des Bezirkes Nr. 0046 im Kreis Nordhausen, 19.4.1982; Information über die Realisierung des Politbürobeschlusses vom 6.4.1982 im Kreis Mühlhausen, 19.5.1982.

19. D. Gabler, Entwicklungsabschnitte der Landwirtschaft in der ehemaligen DDR, Berlin, 1995, pp. 300-4.

20. SAPMO BArch DY60/3097 DBD Bezirksverband, Abt. Parteiorgane, Einschätzung der Mitgliederversammlungen im Monat Dezember 1983, 8.12.1964.

21. Gabler, Entwicklungsabschnitte, pp. 363-71. Diethelm Gabler devotes considerable space in his book to the constitution of the cooperative councils in Bezirk Erfurt, reproducing a number of documents which describe the 
duties and responsibilities required of them and the varying extent to which the KOR claimed to have fulfilled them. It is not clear how far the KOR were able, or needed, to fulfil all these duties and responsibilities in practice. Some cooperations were clearly much more successful than others, although this had as much to do with the productive capacities of the constituent farms as with the competence of the KOR.

22. ThHStAW RdB Erfurt L041358 Wissenschaftlich-technisches Zentrum der Landwirtschaft des Bezirkes Erfurt, Analyse des gegenwärtigen Standes der landwirtschaftlichen Produktion und Schlussfolgerungen zur weiteren Intensivierung der Produktion im Kreis Eisenach Juli/Augst 1982.

23. SAPMO BArch DY30/141 Büro Werner Felfe, Berichterstattung im Politbüro, Material zu einigen Problemen der Entwicklung der Landwirtschaft des Bezirkes Erfurt, 15.5.1983.

24. SAPMO BArch DY60/3097 DBD Bezirksverband, Monatsbericht über die Ergebnisse der Parteiarbeit im Monat November 1984, 8.12.1984.

25. ThHStAW Bezirksparteiarchiv der SED Erfurt, Bezirksleitung der SED Erfurt IV/D/2/7-488 SED Bezirksleitung Abt. Wirtschaftspolitik, Information zur Einhaltung der Dieselkraftstoffkontingente 1981, 11.12.1981, p. 59; RdB Erfurt, Von dem Stellv. des Vorsitzenden für LFN an den Minister für LFN, Gen. Kührig, 21.10.1981, p. 10.

26. SAPMO B-Arch DY30/1512 ZK der SED, Abt. Landwirtschaft, Information zu Schlaggrössen sowie ihr Einfuluss auf den effektiven Einsatz der Technik und geringe Transportentfernungen, 16.11.1981, p. 395.

27. ThHStAW Bezirksparteiarchiv der SED Erfurt, Bezirksleitung der SED Erfurt IV/D/2/5-396 Referat des Stellvetreters des Vorsitzenden f. LFN des Rat des Bezirkes am 15.7.1981, p. 190.

28. BStU Aussenstelle Erfurt, BdL 1031, Dok Nr. 1, Bericht des Leiters der Abt. XVIII zur politisch-operativen Lage in der Landwirtschaft für die Berichterstattung beim Leiter der Bezirksverwaltung am 22.8.1983, 18.8.1983, pp. 3-17.

29. SAPMO B-Arch DY30/1926 ZK der SED, Abt. Landwirtschaft, Standpunkt zur Eingabe des Genossen O., Vorsitzender der LPG P Gamstädt, Kreis Erfurt, 17.11.1981, p. 393.

30. ThHStAW RdB Erfurt L041333 Rat des Bezirkes, Bericht 'Auf der Grundlage des Beschlusses des Politbüros ...' (undated).

31. ThHStAW RdB Erfurt L041325 Ministerrat der DDR, Beschluss über die Durchführung der Agrarpreisreform, 11.11.1982.

32. ThHStAW RdB Erfurt L041333 Rat des Bezirks, Leiter des Fachorgans für Land-, Forst- und Nahrungsgüterwirtschaft, Bericht an das Sekretariat der Bezirksleitung der SED über die Auswirkungen der Agrarpreisreform auf die Entwicklung der sozialistischen Landwirtschaft im Bezirk, 23.5.1984.

33. ThHStAW Bezirksparteiarchiv der SED Erfurt, Bezirksleitung der SED Erfurt Nr. 4964, Rat des Bezirkes Erfurt an das Ministerium für Land-, Forst und Nahrungsgüterwirtschaft ... Analyse zur Wirkung der Agrarpreise ...12.4.1988, p. 84 .

34. ThHStAW RdB Erfurt L041333 SED Bezirksleitung, Stellungnahme zum Bericht des Rates des Bezirkes Erfurt über die Auswirkungen der Agrarpreisreform am 31.5.1984. 
35. SAPMO BArch DY60/3097 DBD Bezirksverband, Einschätzung der Mitgliederversammlungen im Monat Juli 1984, 9.8.1984.

36. SAPMO BArch DY30/32 Büro Werner Felfe, Information für das Politbüro des ZK der SED über die wictigsten Ergebnisse der KBK 1985, 22.4.1985.

37. ThHStAW Bezirksparteiarchiv der SED Erfurt, Bezirksleitung der SED Erfurt Nr. 4047 SED Kreisleitung Sondershausen, Politisch und Organisatorische Massnahmen zur Erfüllung des VW-Planes 1984, 10.9.1984, p. 24.

38. ThHStAW RdB Erfurt L041325 Ministerrat der DDR, Vertrauliche Verschlusssache, Information über die Auswirkungen der Agrarpreisreform auf den Reprodukionsprozess ... 24.5.1984.

39. Staatliche Zentralverwaltung für Statistik, Statistisches Jahrbuch der DDR, 1989, E. Berlin, 1990, pp. 240-2.

40. ThHStAW RdB Erfurt L043382 Rat des Bezirkes, Sekretariat des Stellvertreter der Vorsitzenden für Land-, Forst- und Nahrungsgüterwirtschaft, Bericht an das Sekretariat der Bezirksleitung der SED über die Ergebnisse bei der Festigung der LPG und VEG sowie der weiteren Vertiefung der Kooperation ... 22.9.1987.

41. ThHStAW Bezirksparteiarchiv der SED Erfurt, Bezirksleitung der SED Erfurt Nr. 4964, Rat des Bezirkes Erfurt an das Ministerium für Land-, Forst und Nahrungsgüterwirtschaft ... Analyse zur Wirkung der Agrarpreise ... 12.4.1988. p. 84 .

42. ThHStAW Bezirksparteiarchiv der SED Erfurt, Bezirksleitung der SED Erfurt Nr. 4964, Rat des Bezirkes Erfurt, Stellv. des Vorsitzenden für Land-, Forst- und Nahrungsgüterwirtschaft, Information über die Entwicklung des Rentabilitätsniveau in den LPG ... 2.9.1989, p. 63. 


\section{of Conclusion}

\section{The Practice and Problems of Agricultural Transformation IN THE GDR}

After the 'Socialist Spring' of 1960 the conditions of agricultural production and, with them, the whole nature of rural society in the GDR began to undergo a new stage of radical transformation. This book has sought to clarify the terms on which this transformation took place, highlighting the complexity of authority as social practice in the rural and agricultural context.

By offering farmers and agricultural workers various forms of economic incentive to join or form an LPG and by gradually restricting the profits of independent farmers, the SED leadership had had only limited success during the 1950s in changing the pattern of farming, property ownership and social relations in the countryside - particularly in the south of the GDR where the postwar land reforms had not caused widespread upheaval. By 1958 there remained massive hostility to any notion of abandoning private independent farming in the countryside, and considerable, if less overt, antipathy towards the SED regime in general. Under these circumstances, the SED leadership chose to adopt a more aggressive approach to the transformation of the countryside, beginning to step up the pressure on farmers to agree to collectivise.

The purposes behind the pursuit of collectivisation were fairly straightforward. It promised greater administrative influence by representatives of the state over the methods and processes of food production and would thus, in theory at least, allow stable and systematic increases in productivity to occur across the GDR. It was integral to the pursuit of the SED's ideological agenda, undermining the role of private property as a determinant of social status. No less importantly, it provided the means by which the SED regime could control and limit the local influence of all those it perceived to be hostile or obstructive to its political authority. By the same token, the SED would cease to be a marginal force in rural communities. The network of loyal local representatives of the regime and the broader participation of the farming population in the new hierarchy of authority established in the wake of collectivi- 
sation would, it was intended, ensure the ruling party a permanent and integral presence in rural life.

By 1960, the lack of progress in persuading farmers to form agricultural collectives remained, however, a serious concern for the SED leadership, leading to a decision to initiate intensified agitation campaigns in villages around the GDR, aiming for the rapid completion of full collectivisation. Above all, during March and April 1960, using increasingly heavy-handed intimidation to break down resistance, brigades of agitators succeeded in forcing large numbers of independent farmers to sign up to what was still supposedly a voluntary collectivisation. This was, however, merely the beginning of a gradual process. Not least, given the acrimonious and often inconsistent nature of the collectivisation campaign and the uncertainty of the international political situation in 1960 and 1961, agriculture and rural society in the GDR remained divided and destabilised by conflict over the coming years.

With a micro analysis of the processes of communication and policy implementation in Bezirk Erfurt, this book has attempted to show up in detail how the agricultural administration functioned at the grass roots over the following decades. In so doing it has sought to highlight the complexity and variation, even within a confined area, of the manner and consequences of the SED's transformation of agricultural organisation on the ground, not apparent in other accounts of this period. ${ }^{1}$ Using documents referring to regional and local circumstances from a range of sources, it has been possible to build up a picture of the conflicts and compromises which took place at the front line of agricultural production at various stages during the GDR's existence. With this picture, some light has been shed on the range of factors contributing to a stabilisation of SED authority in the GDR. In rural communities force and fear was but one element driving the process of consolidation of the LPGs, alongside farmers' and rural functionaries' own motives for compromise and participation in the day-to-day development of new structures of agricultural organisation.

With the building of the Wall in August 1961, the SED leadership was certainly in a better position to drive forward social and economic transformation in the countryside under the terms of a specifically 'socialist' modernisation of farming. The conditions of collectivised agriculture, it was argued, would allow the development and funding of new technology and implementation of modern methods to be better managed. It would become possible to increase the productivity of domestic agriculture in predictable and plan-able ways. Under SED guidance the private, small-scale and traditional means of agricultural production were to become progressively more collective, large-scale and indus- 
trial. Achieving these aims in practice was by no means straightforward given the deficit of ideological support for the SED in the countryside and the hostility to state interference among farmers, even once collective farms in general began to achieve some economic stability and grow in stature and permanence as institutions.

What was seen as unnecessary bureaucratisation of the management of collective farms continued to be met with considerable hostility in both Type I and Type III LPGs. District state authorities' demands for quantifiable data on all aspects of the production process were recognised by farmers as a means to exploit their labour and property more efficiently. Attempts to introduce competition between LPG members and accounting regulations designed to quantify waste or inefficiency more precisely appeared to many as little more than tools of administrative control. Meanwhile, the threat to self-determination of finances in each LPG posed by attempts to expand the scale of farming through 'cooperation' roused no less opposition.

The extent to which collective farmers themselves received and understood SED policy and were willing to participate in its implementation did grow during the course of the 1960s. The growing membership of the SED in rural communities, the increasing qualification levels and the material benefits of collective farming had begun to alter the terms of the relationship between farmers and the SED leadership. However, the efficiency with which policy was communicated and with which the authority of the SED was asserted on a day-to-day basis was by no means consistent. The low-level functionaries of party and state operating in rural areas and the managers of the collective farms themselves had a variety of relationships with one another and with LPG members at large which complicated the processes of policy implementation. This situation was made still more complex by the lack of consensus on the proper course of agricultural development and personal and local rivalries amongst farmers and agricultural functionaries, as well as worsening economic shortages. It was in this context that confusion arose in agricultural administration at the end of the Ulbricht era, as the forced evolution of the scale and organisation of collective farming gave way to administrative gridlock and newly virulent assertions of the right to local self-determination by collective farmers and LPG managers.

Despite this period of confusion and economic frailty, the circumstances in which the SED leadership was able to exert its authority over collective farmers were continuing to shift. The proportion of active collective farmers with a tradition of hostility to SED agricultural policy had begun to diminish rapidly. Consistent economic pressure 
was forcing increasing numbers of LPG Type I members - the most reluctant participants in collectivised farming - to retire from agriculture and/or relinquish their livestock to collective control and their land for use in cooperation with other LPGs. Moreover, new generations of professional, specialist collective farmers and agricultural technicians with 'socialist' education and career backgrounds were beginning to take up key positions in the LPGs. Thus it was not long after the VIII SED Party Congress that real progress began to be made in the radical reorganisation of farming on the ground. Now, those functionaries in the party and state administration concerned with rural affairs and in individual LPGs were acting with renewed confidence in the clear direction of agricultural development to arrange the new cooperative crop production units.

Increasingly, LPG members accepted that traditional mixed farms would be broken up into specialised crop and livestock units and expanded separately. In the process, collective farmers would still have to accept often unwelcome changes to their status and the conditions of their labour, not least losing direct claim or connection to the land and livestock of the LPG while having to accept the future disjunction of work from home life. At the same time, however, dismay at these changes and doubts as to the viability of such a specialisation, that is of such a departure from tradition, were offset by renewed state investment in agriculture which promised to bring some immediate improvements to working and living conditions in rural communities. New machinery and new facilities promised to improve productivity, wages were going up and so, it seemed, were living standards as the benefits of Honecker's commitment to consumerist and welfare policies benefited villagers, along with the rest of the population.

By the mid-1970s - a decade and a half after the Socialist Spring - a number of fundamental changes had taken place. Separate administrations ran crop and livestock farming. Huge expanses were now devoted to single crops and could be farmed by specially designed machines. Thousands of animals were being farmed on single sites. Almost all aspects of food production were now firmly tied into and controlled within the planned economy. Almost all the GDR's (now reduced) agricultural workforce had received some formal vocational qualification and begun to specialise in a particular branch of production. SED members dominated the top management positions in the collective farms, and were backed by better-organised SED party organisations. Moreover, the prospects for further improvement to productivity were far from exhausted. Mechanised and intensive farming methods promised to become both more productive and more consistent. 
However, as the economic climate in the GDR as a whole began to deteriorate, agriculture in particular was faced by unsustainable rises in production costs. Ironically, these were problems that the new structures of organisation tended to some extent to exacerbate. Crop production was now so structured towards the use of labour-saving, high-intensity methods and on such a large scale with a finely balanced system of agro-technical deadlines, that coping with cuts to fuel, fertiliser and machinery threatened to undermine the economies of scale. At the same time, livestock production was increasingly dependent on energy to run intensive production plants, as well as on fuel for efficient transport of feed as well as animals. The consolidation of industrialstyle agriculture during the late 1970s occurred at the same time as a number of factors converged to undermine the strength of the East German economy and deprive industrialised agriculture of the necessary inputs in order to make it efficient. Rising prices on the world markets and cuts to financial and material support coming from the Soviet Union led to shortages of fuel and fertiliser. Moreover, the GDR's national debt had risen exponentially during the 1970s, with the result that there were limits on the amount of Western currency which could be spent on imports, particularly of necessary feed supplies, while machinery manufactured in the GDR was necessarily being made available for export despite an unsatisfied demand at home. ${ }^{2}$

After the conflicts of the previous decade, the structures of SED authority in agriculture and, thus, in rural society more generally, had effectively stabilised. Yet almost simultaneously, economic stagnation and decline had begun to establish the bases for renewed material dissatisfaction among sections of the rural population. A tighter prioritisation of resources at all levels led inevitably to some casualties of administrative rationalisation, resulting in increasing differentiation in living and working conditions between LPGs and rural communities. ${ }^{3}$ In these circumstances agricultural production appeared to be becoming less rather than more efficient. ${ }^{4}$ By the mid-1980s the negative effects on living and working conditions in rural communities of the policy of gigantism in agriculture were exacerbated by the inefficiencies of the planned economy. Shortages of essential materials and fuel as well as the environmental impact of industrialised agriculture undermined the advantages of the SED's radical transformative social and economic policies in the countryside.

Amid much conflict and compromise a limited social and economic transformation of the conditions of agricultural production developed following the completion of full collectivisation, transforming the context in which the SED leadership sought to assert its authority over 
agricultural production and rural society. Ultimately, however, the reconfiguration of the administration of agriculture at the grass roots proved unable to prevent - indeed arguably exacerbated - the problems of production. By 1989, the concomitant disparities and hardship faced by those living and working in rural communities could but undermine further the SED leadership's claims to legitimacy, based as it was on a commitment to equality and material progress.

\section{Notes}

1. D. Gabler, Entwicklungsabschnitte der Landwirtschaft in der ehemaligen DDR, Berlin, 1995. This account of agricultural development in Bezirk Erfurt in various periods from the 1950 s to 1989 , though detailed in its survey of the various structures of collectivised and industrialised agriculture, makes only very limited use of the available sources, tending to provide a superficial account of the practice of policy implementation.

2. SAPMO BArch IV/B 2/2.023/2 Büro Gerhard Grüneberg, ZK der SED Abt. Landwirtschaft an Honecker, Entwicklungsprobleme der Landwirtschaft bei der weiteren Durchführung der Beschlüsse des VIII. und IX. Parteitages, 31.10.1979.

3. SAPMO BArch IV/B 2/2.023/61 Komitee der ABI, Information über Kontrollergebnisse zur Entwicklung der Tierverluste in der Rinder- und Schweinehaltung, 21.11.1978; DY30/1512 ZK der SED Abt. Landwirtschaft, Standpunkt zu den neuen Forderungen der staatlichen Plankommission, 8.9.1981, p. 299.

4. SAPMO BArch DY30/1541 ZK der SED Abt. Landwirtschaft, Tendenzen, Ergebnisse und Schlussfolgerungen aus den 7 Bezirksanalysen, 24.4.1979, pp. 33-56. 


\title{
의 Bibliography
}

\section{UNPUBLISHED SOURCES}

(see endnotes for details of individual files)

\author{
Bundesarchiv, Berlin, Abteilung DDR (BArch) \\ DK 1: Ministerium für Land-, Forst- und Nahrungsgüterwirtschaft. \\ DE 1: Staatliche Plankomission (SPK). \\ DP 1: Ministerium der Justiz.
}

\section{Stiftung der Parteien und Massenorganisationen der DDR im Bundesarchiv, Berlin (SAPMO BArch)}

DY60: Demokratische Bauernpartei Deutschlands (DBD).

DY 30: Tagungen des Parteivorstandes und des ZK der SED; Beschlüsse des Politbüros der SED; Büro Erich Honecker; Büro Gerhard Grüneberg; Büro Werner Felfe; Büro Walter Ulbricht; Abt. Landwirtschaft des ZK der SED; Abt. Parteiorgane des ZK der SED.

\section{Thüringisches Hauptstaatsarchiv, Weimar (ThHstAW)}

Bezirksbehörde der Deutschen Volkspolizei (BDVP).

Rat des Bezirkes Erfurt: L (Landwirtschaft); Umweltschutz/Wasserwirtschaft (U).

\section{ThHstAW SED Bezirksparteiarchiv Erfurt}

Bezirksleitung der SED Erfurt: Sekretariat; Abt. Landwirtschaft; Abt. Parteiorgane; Ideologische Kommission; Abt. Organisation/Kader; Abt. Befreundete Parteien; Bezirksparteikontrollkommission (BPKK).

Kreisleitung der SED Sömmerda: Abt. Landwirtschaft; Abt. Parteiorgane; Ideologische Kommission; Abt. Organisation/Kader (Abt. Org./Kader); Abt. Befreundete Parteien; Kreisparteikontrollkommission (KPKK)

Bezirkssekretariat der Nationalen Front (NF)

\section{Kreisarchiv Sömmerda (KAS)}

Rat des Kreises Sömmerda

Rat des Kreises Erfurt 


\section{Bezirksbeauftragter für die Unterlagen des Staatssicherheitsdienstes, Aussenstelle Erfurt (BstU)}

Bezirksverwaltung Erfurt - Büro der Leitung (BdL)

Kreisdienststelle Weimar (KD Weimar)

Kreisdienststelle Heiligenstadt (KD Heiligenstadt)

\section{PUBLISHED SOURCES}

Eckart, G. So sehe ick die Sache-Protokolle aus der DDR. Leben im Havelländischen Obstanbaugebiet. Cologne, 1984.

Gesetzblatt der DDR 1959. Berlin, 1959.

Judt, M., ed. DDR-Geschichte in Dokumenten. Bonn, 1998.

Kleßmann, C. and G. Wagner, eds. Das Gespaltene Land: Leben in Deutschland 1945-1990, Texte und Dokumente zur Sozialgeschichte. Munich, 1993.

Kuntsche, S. et al., eds. Wie wir angefangen haben. Berlin, 1985.

Staatliche Zentralverwaltung für Statistik, Bezirksstelle Erfurt Statistische Jahrbücher, Bezirk Erfurt, 1955-1975. Erfurt, 1956-76.

\section{SECONDARY LITERATURE}

Ahrends, K. et al. (Autorenkollektiv). Landwirtschaft in der DDR - Theorie und Praxis. E. Berlin, 1989.

Akademie der Landwirtschaftswissenschaften der DDR. Sozialistische Betriebswirtschaft der Landwirtschaft. E. Berlin, 1985.

Allinson, M. Politics and Popular Opinion in East Germany, 1945-1968. Manchester, 2000.

Anders, H. Die sozialistische Intensivierung und der Übergang zu industriemässigen Produktionsmethoden in der Landwirtschaft. E. Berlin, 1978.

Arlt, R. Rechte und Pflichten der Genossenschaftsbauern. E. Berlin, 1965.

Arlt, R. et al. Staatliche Leitung der Landwirtschaft in der DDR und der UdSSR. E. Berlin, 1980.

Augusten, F. Die Organisation der Rinderzucht im Bezirk Erfurt von 1945 bis 1989. Aachen, 1997.

Badstübner, E., ed. Befremdlich Anders: Leben in der DDR. Berlin, 2000.

Bajaja, V. Organisation und Führung landwirtschaftlicher Grossunternehmen in der DDR. W. Berlin, 1978.

Bauer, T. Blockpartei und Agrarrevolution von Oben: Die DBD, 1948-1963. Munich, 2003.

Bauerkämper, A. 'Die Bodenreform in der Sowjetischen Besatzungszone in vergleichender und beziehungsgeschichtlicher Perspektive', in Junkerland in Bauernhand"? Durchführung, Auswirkungen und Stellenwert der Bodenreform in der Sowjetischen Besatzungszone, ed. A. Bauerkämper. Stuttgart, 1996, pp. 7-19.

'Agrarwirtschaft und ländliche Gesellschaft in der BRD und DDR', Aus Politik und Zeitgeschichte 47(2) (1997), B38/97, pp. 25-37. 
'Kaderdiktatur und Kadergesellschaft. Politische Herrschaft, Milieubeziehungen und Wertetraditionalismus im Elitenwechsel in der SBZ/DDR von 1945 bis zu den sechziger Jahren', in Eliten im Sozialismus: Beiträge zur Sozialgeschichte der DDR, ed. P. Hübner. Cologne, 1999, pp. 37-65.

'Aufwertung und Nivellierung. Landarbeiter und Agrarpolitik in der SBZ/DDR 1945-1960', in Arbeiter in der SBZ/DDR, ed. P. Hübner. Essen, 1999, pp. 245-67.

'Die vorgetäuschte Integration. Die Auswirkungen der Bodenreform und Flüchtlingssiedlung auf die berufliche Eingliederung von Vertriebenen in die Landwirtschaft in Deutschland 1945-1960', in Geglückte Integration? Spezifika und Vergleichbarkeiten der Vertriebenen-Eingliederung in der SBZ/DDR, eds D. Hoffmann and M. Schwartz. Munich, 1999, pp. 193-214.

'Zwangsmodernisierung und Krisenzyklen. Die Bodenreform und Kollektivierung in Brandenburg, 1945-1960/61', Geschichte und Gesellschaft 25 (1999), pp. 556-88

_Loyale "Kader"? Neue Eliten und die SED Gesellschaftspolitik auf dem Lande von 1945 bis zu den frühen 1960er Jahren', Archiv für Sozialgeschichte 39 (1999), pp. 265-98.

— Ländliche Gesellschaft in der kommunistischen Diktatur: Zwangsmodernisierung und Tradition in Brandenburg, 1945-1963. Weimar, 2002.

'Traditionalität in der Moderne. Agrarwirtschaft und ländliche Gesellschaft in Mecklenburg nach 1945', Zeitschrift für Agrargeschichte und Agrarsoziologie 2(51) (2003), pp. 2-32.

Bauerkämper, A., ed. Junkerland in Bauernhand? Durchführung, Auswirkungen und Stellenwert der Bodenreform in der Sowjetischen Besatzungszone. Stuttgart, 1996.

Bauerkämper, A., J. Danyel and P. Hübner. 'Funktionäre des schaffenden Volkes?', in Gesellschaft ohne Eliten? eds A. Bauerkämper, J. Danyel, P. Hübner and S. Roß. Berlin, 1997, pp. 11-86.

Bauerkämper, A., J. Danyel, P. Hübner and S. Roß, eds. Gesellschaft ohne Eliten? Berlin, 1997.

Becker, F., I. Merkel and S. Tippach-Schneider, eds. Das Kollektiv bin Ich - Utopie und Alltag in der DDR. Cologne, 2000.

Becker, P. and A. Lüdtke, eds. Akten, Eingaben, Schaufenster: Die DDR und ihre Texte. Erkundungen zu Herrschaft und Alltag. Berlin, 1997.

Berdahl, D. Where the World Ended. Berkeley, 1999.

Berthold, T. Die Agrarpreispolitik der DDR: Ziele, Mittel, Wirkungen. W. Berlin, 1972.

Bessel, R. 'The People's Police and the People in Ulbricht's Germany', in The Workers' and Peasants' State: Communism and Society in East Germany Under Ulbricht, 1945-1971, eds P. Major and J. Osmond. Manchester, 2002, pp. 59-77.

Bessel, R. and R. Jessen. 'Einleitung: Die Grenzen der Diktatur', in Die Grenzen der Diktatur: Staat und Gesellschaft in der DDR, eds R. Bessel and R. Jessen. Göttingen, 1996, pp. 7-23.

Bessel, R. and R. Jessen, eds. Die Grenzen der Diktatur: Staat und Gesellschaft in der DDR. Göttingen, 1996.

Best, H. and S. Hornbostel. Funktionseliten der DDR: Theoretische Kontroversen und empirische Befunde/The GDR's Functional Elites: Theoretical Discussion and 
Empirical Results, Special Issue, Historical Social Research/Historische Sozialforschung, 28, 1/2 (2003).

Best, H. and H. Mestrup, eds. Die Ersten und Zweiten Sekretäre der SED: Machtstrukturen und Herrschaftspraxis in den thüringischen Bezirken der DDR. Jena, 2003.

Bollinger, S. and F. Vilmar, eds. Die DDR war anders. Berlin, 2002.

Bouvier, B. Die DDR - ein Sozialstaat? Soziapolitik in der Ära Honecker. Bonn, 2002.

Boyer, C. 'Kommentar zum Referat “Norm, Normalität, Normalisierung: Quellen und Ziele eines gesellschaftspolitischen Paradigmenwechsels im sowjetischen Block um 1970"', in Potsdamer Bulletin, 28/29 (January, 2003), pp. $41-45$.

'Das Wirtschafts- und Sozialrecht im Steuerungs- und Stabilisierungskonzept der SED. Die Einheit von Wirtschafts- und Sozialpolitik in den achtziger Jahren', Deutschland Archiv 4 (2003), pp. 626-39.

Brauer, K., A. Willisch and F. Ernst. 'Die Landwirtschaft in der DDR und nach der Wende - Lebenswirklichkeit zwischen Kollektivierung und Transformation.

Empirische Langzeitstudie", in Materialien der Enquete-Kommission "Uberwindung der Folgen der SED-Diktatur im Prozess der deutschen Einheit", III/2. Baden-Baden, 1999, pp. 1325-428.

Breitschuh, G. et al. Thüringer Landwirtschaft zwischen 2. Weltkrieg und Wiedervereinigung. Jena, 1999.

Bürgerkomitee Leipzig ed. STASI Intern: Macht und Banalität. Leipzig, 1998.

Busse, T. Melken und Gemolken Werden: Die ostdeutsche Landwirtschaft nach der Wende. Berlin, 2001.

Childs, D. The GDR: Moscow's German Ally. 2nd edn. London, 1988.

Dennis, M. The Stasi: Myth and Reality. London, 2003.

Dokumentationszentrum Alltagskultur der DDR e.V., ed. Fortschritt, Norm und Eigensinn: Erkundungen im Alltag der DDR. Berlin, 1999.

Dreessen, K. Die Bedeutung der Landwirtschaftlichen Produktionsgenossenschaft für die DDR. Tübingen, 1973.

Eckart, G. So sehe ick die Sache - Protokolle aus der DDR: Leben im Havelländischen Obstanbaugebiet. Cologne, 1984.

Egler, G. et al. eds. Zum NÖS. E. Berlin, 1965.

Engler, W. Die Ostdeutschen: Kunde von einem verlorenen Land. Berlin, 1999.

Eppelmann, R., H. Möller, G. Nooke and D. Wilms, eds. Lexikon des DDRSozialismus. Das Staats- und Gesellschaftssystem der Deutschen Demokratischen Republik. Paderborn, 1997.

Eppelmann, R., B. Faulenbach and U. Mählert, eds. Bilanz und Perspektiven der DDR Forschung. Paderborn, 2003.

Fitzpatrick, S. Stalin's Peasants: Resistance and Survival in the Russian Village after Collectivisation. Oxford, 1996.

Fricke, K.-W., P. Steinbach and J. Tuchel. Opposition und Widerstand in der DDR: Politische Lebensbilder. Munich, 2002.

Fulbrook, M. Anatomy of a Dictatorship: Inside the GDR, 1949-1990. Oxford, 1995.

German National Identity After the Holocaust. Cambridge, 1998. 
'Aspects of Society and Identity in the New Germany', in In Search of Germany, eds M. Mertes, S. Muller and H.A. Winkler. New Brunswick, NJ, 1999, pp. 229-52.

The Two Germanies, 1945-1990: Problems of Interpretation. Basingstoke, 1992.

'Methodologische Überlegungen zu einer Gesellschaftsgeschichte der DDR', in Die Grenzen der Diktatur: Staat und Gesellschaft in der DDR, eds R. Bessel and R. Jessen. Göttingen, 1996, pp. 274-97.

'Ein ganz normales Leben? Neue Forschungen zur Sozialgeschichte der DDR', Das war die DDR, DDR-Forschung im Fadenkreuz von Herrschaft, Außenbeziehungen, Kultur und Souveränität, ed. H. Timmermann. Münster, 2004, pp. 115-34.

'Retheorising "State" and "Society" in the German Democratic Republic', in The Workers' and Peasants' State: Communism and Society in East Germany under Ulbricht, 1945-1971, eds P. Major and J. Osmond. Manchester, 2002, pp. 280-98.

Fürmetz, G. et al., eds. Nachkriegspolizei: Sicherheit und Ordnung in Ost- und Westdeutschland, 1945-1969. Hamburg, 2001.

Gabler, D. Entwicklungsabschnitte der Landwirtschaft in der ehemaligen DDR. Berlin, 1995.

Gaus, G. Wo Deutschland liegt: Eine Ortsbestimmung. Hamburg, 1983.

Gebhardt, W. and G. Kamphausen. Zwei Dörfer in Deutschland: Mentalitätsunterschiede nach der Wiedervereinigung. Opladen, 1994.

Geiss, I. The Question of German Unification: 1806-1996. London, 1997.

Geissler, R., ed. Sozialer Umbruch in Ostdeutschland. Opladen, 1993.

Gieseke, J. 'Ulbricht's Secret Police: the Ministry of State Security', in The Workers' and Peasants' State: Communism and Society in East Germany under Ulbricht 1945-1971, eds P. Major and J. Osmond. Manchester, 2002, pp. 41-58.

Giordano, C. 'Die vergessenen Bauern. Agrarwissenschaften als Objekt sozialwissenschaftlicher Amnesie', in Bauerngesellschaften im Industriezeitalter. Zur Rekonstruktion ländlicher Lebensformen, eds C. Giordano and R. Hettlage. Berlin, 1989, pp. 9-27.

Giordano, C. and R. Hettlage, eds. Bauerngesellschaften im Industriezeitalter. Zur Rekonstruktion ländlicher Lebensformen. Berlin, 1989.

Glaeßner, G.-J., ed. Die DDR in der Ära Honecker: Politik - Kultur - Gesellschaft. Opladen, 1988.

Grieder, P. 'The Leadership of the Socialist Unity Party of Germany under Ulbricht', in The Workers' and Peasants' State: Communism and Society in East Germany under Ulbricht, 1945-1971, eds P. Major and J. Osmond. Manchester, 2002, pp. 22-40.

Groschoff, K. Stadt und Land in der DDR. Entwicklung - Bilanz - Perspektiven. Berlin, 1984.

Groschoff, K. et al. (Autorenkollektiv). Industriemässige Produktionsmethoden in der sozialistischen Landwirtschaft der DDR. Berlin, 1976.

Gruhle, J. Ohne Gott und Sonnenschein. Nauendorf 2000.

Grühn, W. et al., eds. Umweltprobleme und Umweltbewusstsein in der DDR. Cologne, 1985. 
Grünberg, H. Die sozialistische Wandlung des Dorfes. E. Berlin, 1970.

Grüneberg, G. Die marxistisch-leninistische Agrarpolitik von der gegenseitigen Bauernhilfe und demokratischen Bodenreform zur Ausarbeitung und Anwendung des neuen ökonomischen Systems der Planung und Leitung in der Landwirtschaft der DDR. Berlin, 1965.

- Der IX. Parteitag der SED über die Aufgaben der Land- und Nahrungsgüterwirtschaft sowie die weitere gesellschaftliche Entwicklung auf dem Lande. Berlin, 1976.

Haendcke-Hoppe, M. and K. Merkel, eds. Umweltschutz in beiden Teilen Deutschlands. W. Berlin, 1986.

Hanke, H. Kultur und Lebensweise im sozialistischen Dorf. Berlin, 1967.

Hartmann, T. Die Kooperation in der sozialistischen Landwirtschaft der DDR. W. Berlin, 1971.

Henke, K.-D., P. Steinbach and J. Tuchel, eds. Widerstand und Opposition in der DDR. Cologne, 1999.

Herbst, A., G.-R. Stephan and J. Winkler, eds. Die SED. Geschichte-Organisation - Politik: Ein Handbuch. Berlin, 1997.

Heuer, K. Genossenschaftliche Demokratie als Führungsaufgabe: Rechtsfragen der Leitung der LPG und der Beziehungen zur Kooperationsgemeinschaft. E. Berlin, 1968.

Heuer, U.-J. Demokratie und Recht im neuen ökonomischen System der Planung und Leitung der Volkswirtschaft. E. Berlin, 1965.

_ Leiter und Vertrag - Der Liefervertrag als Instrument zur Organisierung der zwischenbetrieblichen Kooperation. E. Berlin, 1977.

Hoffmann, G. et al (Autorenkollektiv). Handbuch: Bürgermeister. E. Berlin, 1978.

Hohmann, K. ‘Die Industrialisierung der Landwirtschaft und ihre Auswirkungen auf die Umwelt in der DDR', in Umweltschutz in beiden Teilen Deutschlands, eds M. Haendcke-Hoppe and K. Merkel. W. Berlin, 1986, pp. 41-67.

Hornbostel, S., ed. Sozialistische Eliten: Horizontale und Vertikale Differenzierungsmuster in der DDR. Opladen, 1999.

Hübner, P. Konsens, Konflikt und Kompromiss: Soziale Arbeiterinteressen und Sozialpolitik in der SBZ/DDR, 1945-1970. Berlin, 1995.

— 'Norm, Normalität, Normalisierung: Quellen und Ziele eines gesellschaftspolitischen Paradigmenwechsels im sowjetischen Block um 1970', Potsdamer Bulletin 28/29 (January 2003), pp. 24-40.

Hübner, P., ed. Eliten im Sozialismus: Beiträge zur Sozialgeschichte der DDR. Cologne, 1999.

Hübner P. and J. Danyel. 'Soziale Argumente im Politischen Machtkampf: Prag, Warschau, Berlin, 1968-1971', Zeitschrift für Geschichtswissenschaft 11 (2002), pp. 804-32.

Hübner P. and K. Tenfelde, eds. Arbeiter in der SBZ-DDR. Essen, 1999.

Huinink, J., K.-U. Meyer, M. Diewald and H. Solga, eds. Kollektiv und Eigensinn: Lebensläufe in der DDR und danach. Berlin, 1995.

Humm, A.-M. Auf dem Weg zum sozialistischen Dorf? Zum Wandel der dörflichen Lebenswelt in der DDR von 1952-1969 mit vergleichenden Aspekten zur Bundesrepublik Deutschland. Göttingen, 1999.

Hürtgen, R. 'Entwicklung in der Stagnation? Oder: Was ist so spannend am Betriebsalltag der siebziger und achtziger Jahre in der DDR?', in Der Schein 
der Stabilität: DDR Betriebsalltag in der Ära Honecker, eds R. Hürtgen and T. Reichel. Berlin, 2001, pp. 11-34.

Hürtgen, R. and T. Reichel, eds. Der Schein der Stabilität: DDR Betriebsalltag in der Ära Honecker. Berlin, 2001.

Immler, H. Agrarpolitik in der DDR. Cologne, 1973.

Jarausch, K. 'Care and Coercion: the GDR as Welfare Dictatorship', in Dictatorship as Experience: Towards a Socio-Cultural History of the GDR, ed. K. Jarausch. Oxford, 1999, pp. 47-69.

Jarausch, K., ed. Dictatorship as Experience: Towards a Socio-Cultural History of the GDR. Oxford, 1999.

Jarausch, K. and M. Sabrow, eds. Weg in den Untergang: der innere Zerfall der DDR. Göttingen, 1999.

Jesse, E., ed. Totalitarismus im 20. Jahrhundert: Eine Bilanz der internationalen Forschung. Bonn, 1996.

Jessen, R. 'Die Gesellschaft im Staatssozialismus: Probleme einer Sozialgeschichte der DDR', in Geschichte und Gesellschaft 21 (1995), pp. 96-110.

_ 'Diktatorische Herrschaft als kommunale Praxis: Überlegungen zum Zusammenhang von "Bürokratie" und Sprachnormierung in der DDR Geschichte', in Akten, Eingaben, Schaufenster: Die DDR und ihre Texte. Erkundungen zu Herrschaft und Alltag, eds A. Lüdtke and P. Becker. Berlin, 1997, pp. 57-75.

Kaelble, H., J. Kocka and H. Zwahr, eds. Sozialgeschichte der DDR. Stuttgart, 1994.

Kaiser, J.-C. 'Klientelbildung und Formierung einer neuen politischen Kultur. Uberlegungen zur Geschichte der Bodenreform in Thüringen', in Junkerland in Bauernhand, ed. A. Bauerkämper. Stuttgart, 1996, pp. 119-31.

Kaiser, M. Machtwechsel von Ulbricht zu Honecker: Funktionsmechanismen der SED-Diktatur in Konfliktsituationen, 1962-1972. Berlin, 1997.

Keller, D. et al., eds. Ansichten zur Geschichte der DDR. Vol. 1. Bonn, 1993.

Kermarrec, P. Der 17. Juni 1953 im Bezirk Erfurt. Erfurt, 2003.

Kipping, M. Die Bauern in Oberwiera: Landwirtschaft im Sächsisch-Thüringischen 1945 bis 1990. Beucha, 2000.

Klages, K. and O. Wilson. 'Farm Restructuring in the Ex-GDR: Towards a New Farm Model?', Journal of Rural Studies 17 (2001), pp. 277-91.

Klenke, D. Das Eichsfeld unter den deutschen Diktaturen: Widerspenstiger Katholizismus in Heiligenstadt. Duderstadt, 2003.

Klessmann, C. 'Die Beharrungskraft traditioneller Milieus in der DDR', in Was ist Gesellschaftsgeschichte? Positionen, Themen, Analysen, eds Manfred Hertling et al. Munich, 1991, pp. 146-54.

- 'Zur Sozialgeschichte des protestantischen Milieus in der DDR', in Geschichte und Gesellschaft 19 (1993), pp. 29-53.

- Zwei Staaten, eine Nation: Deutsche Geschichte, 1955-1970. Bonn, 1997.

'Relikte des Bildungsbürgertums in der DDR', in Sozialgeschichte der DDR, eds H. Kaeble, J. Kocka and H. Zwahr. Stuttgart, 1994, pp. 254-70.

Kluge, U. 'Die "sozialistische Landwirtschaft" als Thema wissenschaftlicher Forschung', in Zwischen Bodenreform und Kollektivierung: Vor- und Frühgeschichte der "sozialistischen Landwirtschaft" in der SBZ/DDR vom Kriegsende 
bis in die fünfziger Jahre, eds U. Kluge, W. Halder and K. Schlenker. Stuttgart, 2001, pp. 11-48

- Agrarwirtschaft und Ländliche Gesellschaft im 20. Jahrhundert. Munich, 2005.

'Rezension: Theresia Bauer, Blockpartei und Agrarrevolution von Oben. Die DBD 1948-1963', Zeitschrift für Agrargeschichte und Agrarsoziologie 1(53) (2005), pp. 131-3.

Kluge, U., W. Halder and K. Schlenker, eds. Zwischen Bodenreform und Kollektivierung: Vor- und Frühgeschichte der "sozialistischen Landwirtschaft" in der SBZ/DDR vom Kriegsende bis in die fünfziger Jahre. Stuttgart, 2001.

Kocka, J. 'Die Geschichte der DDR als Forschungsproblem', in Die DDR als Geschichte: Fragen - Hypothesen - Perspektiven, eds J. Kocka and M. Sabrow. Berlin, 1994, pp. 9-26.

— 'Eine durchherrschte Gesellschaft', in Sozialgeschichte der DDR, eds H.Kaeble, J. Kocka and H. Zwahr. Stuttgart, 1994, pp. 547-53.

Kocka, J. and M. Sabrow, eds. Die DDR als Geschichte: Fragen - Hypothesen - Perspektiven. Berlin, 1994.

Kopstein, J. The Politics of Economic Decline in East Germany, 1945-1989. Chapel Hill, 1997.

Kowalczuk, I.-S. Legitimation eines neuen Staates. Berlin, 1997.

Krambach, K. Wie lebt man auf dem Dorf? Soziologische Aspekte der Entwicklung des Dorfes in der DDR. Berlin, 1985.

Krambach, K. et al. Genossenschaftsbauer-Verantwortung-Bewusstsein. E. Berlin, 1973.

Krambach, K. et al. Die Genossenschaftsbauern in den achtziger Jahren. Berlin, 1984.

Kramer, M. et al., eds. Die Landwirtschaft in der sowjetischen Besatzungszone: Die Entwicklung in den Jahren 1945-1955. Bonn, 1957.

Krebs, C. 'Arbeitsorganisation und Lebensbedingungen in der Landwirtschaft der DDR', in Arbeits- und Lebensbedingungen in Industrie und Landwirtschaft der DDR, ed. Deutschland Archiv. Cologne, 1975, pp. 69-84.

Der Weg zur industriemässigen Organisation der Agrarproduktion in der DDR: Die Agrarpolitik der SED, 1945-1960. Bonn, 1989.

Kuntsche, S. 'Die Umgestaltung der Eigentumsverhältnisse und der Produktionsstruktur in der Landwirtschaft', in Ansichten zur Geschichte der DDR, Vol. 1, eds D. Keller et al. Bonn, 1993, pp. 191-211.

'Das Bauerndorf in der Nachkriegszeit. Lebenslage und Alltag', in Befremdlich Anders: Leben in der DDR, ed. E. Badstübner. Berlin, 2000, pp. 117-41.

'Warum bemühen wir uns um die Geshichte der Agrargenossenschaften?', Sächsisches Genossenschaftsblatt 9 (2002).

'Agrargenossenschaft in Vergangenheit und Gegenwart: Ein Kolloqium im Thünen Museum 14. und 15. Juni 2002 in Teltow. Ein Tagungsbericht', Zeitschrift für Agrargeschichte und Agrarsoziologie 2(51) (2003), pp. 85-93.

Kurt, E., ed. Die Endzeit der DDR Wirtschaft. Opladen, 1989.

Lambrecht, H. Die Landwirtschaft der DDR vor und nach ihrer Umgestaltung im Jahre 1960. Berlin, 1977. 
Lang, R. 'Der Kampf mit dem Korn: Aufgaben und Probleme der Betriebe im ehemaligen Kombinat Getreidewirtschaft Karl-Marx-Stadt', in Zwischen Plan und Pleite, ed. F. Thiessen. Cologne, 2001, pp. 203-10.

Langenhahn, D. 'Auf dem Weg zur genossenschaftlichen Demokratie?' in Der Schein der Stabilität. DDR Betriebsalltag in der Ara Honecker, eds. R. Hürtgen and T. Reichel. Berlin, 2001, pp. 263-74.

"“Wir waren ideologisch nicht ausgerichtet auf die industriemässige Produktion." Machtbildung und forcierter Strukturwandel in der Landwirtschaft der DDR der 1970er Jahre', in Zeitschrift für Agrargeschichte und Agrarsoziologie 2(51) (2003), pp. 47-55.

Langenhahn, D. and S. Roß. 'Berufskarrieren von Frauen', in Sozialistische Eliten: Horizontale und Vertikale Differenzierungsmuster in der DDR, ed. S. Hornbostel. Opladen, 1999, pp. 147-62.

Lindenberger, T. 'Alltagsgeschichte und ihr möglicher Beitrag zu einer Gesellschaftsgeschichte der DDR', in Die Grenzen der Diktatur: Staat und Gesellschaft in der DDR, eds R. Bessel and R. Jessen, Göttingen, 1996, pp. 298-325.

— 'Die Diktatur der Grenzen. Zur Einleitung', in Herrschaft und Eigen-Sinn in der Diktatur: Studien zur Gesellschaftsgeschichte der DDR, ed. T. Lindenberger. Cologne, 1999, pp. 13-44.

'Der ABV als Landwirt', in Herrschaft und Eigen-Sinn in der Diktatur: Studien zur Gesellschaftsgeschichte der DDR, ed. T. Lindenberger. Cologne, 1999, pp. 167-203.

— 'Herrschaft und Eigen-Sinn in der Diktatur. Das Alltagsleben der DDR und sein Platz in der Erinnerungskultur des vereinigten Deutschlands', Aus Politik und Zeitgeschichte B40 (2000), pp. 5-12.

'Vaters kleine Helfer. Die Volkspolizei und ihre enge Verbindung zur Bevölkerung, 1952-1965', in Nachkriegspolizei: Sicherheit und Ordnung in Ost- und Westdeutschland, 1945-1969, eds Gerhard Fürmetz et al. Hamburg, 2001.

Volkspolizei. Cologne, 2003.

Lindenberger, T., ed. Herrschaft und Eigen-Sinn in der Diktatur: Studien zur Gesellschaftsgeschichte der DDR. Cologne, 1999.

Lüdtke, A. Eigen-Sinn, Fabrikalltag, Arbeitererfahrungen und Politik vom Kaiserreich bis in den Faschismus. Ergebnisse. Hamburg, 1993.

— 'Einleitung: Herrschaft als soziale Praxis', in Herrschaft als Soziale Praxis: Historische und sozial-anthropologische Studien, ed. A. Lüdtke. Göttingen, 1991, pp. 9-63.

'Die DDR als Geschichte. Zur Geschichtsschreibung über die DDR', Aus Politik und Zeitgeschichte B36 (1998), pp. 3-16.

'Meister der Landtechnik oder: Grenzen der Feldforschung? Annäherung an einen "Qualitätsarbeiter" auf dem Lande im Bezirk Erfurt', in Geschichte als Experiment: Studien in Politik, Kulture und Alltag, eds D. Münkel and J. Schwarzkopf. Frankfurt am Main, 2004, pp. 243-57.

Lüdtke, A., ed. Herrschaft als Soziale Praxis: Historische und sozial-anthropologische Studien. Göttingen, 1991.

Ludz, P.-C. Die DDR zwischen Ost und West: Politische Analysen von 1961 bis 1967. Munich, 1997.

— The Changing Party Elite in East Germany. London, 1972. 
Luft, H. 'Von der LPG zur Agrargenossenschaft: Eine positive Entwicklung?', in Die DDR war anders, eds S. Bollinger and F. Vilmar. Berlin, 2002, pp. 206-25.

Madarász, J. Conflict and Compromise in East Germany, 1971-1989: A Precarious Stability. Basingstoke, 2003.

_ 'Normalisierung im Kontext der Betriebspolitik der sechziger Jahre', Das war die DDR: DDR-Forschung im Fadenkreuz von Herrschaft, Außenbeziehungen, Kultur und Souveränität, ed. H. Timmermann. Münster, 2004, pp. 322-32.

Maier, C.S. Dissolution: The Crisis of Communism and the End of East Germany. Princeton, 1999.

Major, P. “ "Mit Panzern kann man doch nicht für den Frieden sein”. Die Stimmung der DDR-Bevölkerung zum Bau der Berliner Mauer am 13. August 1961 im Spiegel der Parteiberichte der SED', Jahrbuch für Kommunismusforschung (1995), pp. 208-23.

Major, P. and J. Osmond, eds. The Workers' and Peasants' State: Communism and Society in East Germany under Ulbricht, 1945-1971. Manchester, 2002.

Manz, G., E. Sachse and G. Winkler, eds. Sozialpolitik in der DDR: Ziele und Wirklichkeit. Berlin, 2001.

MacFalls, L.H. Communism's Collapse, Democracy's Demise. Basingstoke, 1995.

Merkel, I. Utopie und Bedürfnis: Die Geschichte der Konsumkultur in der DDR. Cologne, 1999.

_ _ '“...in Hoyerswerda leben jedenfalls keine so kleinen viereckigen Menschen", Briefe an das Fernsehen der DDR', in Akten, Eingaben, Schaufenster: Die DDR und ihre Texte. Erkundungen zu Herrschaft und Alltag, eds A. Lüdtke and P. Becker. Berlin, 1997, pp. 279-310.

'Konsumkultur in der DDR: Über das Scheitern der Gegenmoderne auf dem Schlachtfeld des Konsums', Mitteilungen aus der kulturwissenschaftlichen Forschung (February 1996), pp. 314-30.

Merkel, I., ed. Wir sind doch nicht die Meckerecke der Nation! Briefe an das Fernsehen der DDR. 2nd edn. Berlin, 2000.

Merkel, I. and F. Mühlberg. 'Eingaben und Öffentlichkeit', in Wir sind doch nicht die Meckerecke der Nation! Briefe an das Fernsehen der DDR, ed. I. Merkel. 2nd edn. Berlin, 2000, pp. 11-46.

Merkel, K. and E. Schuhans. Die Agrarwirtschaft in Mitteldeutschland: 'Sozialisierung' und Produktionsergebnisse. Bonn, 1963.

Merl, S. and E. Schinke, eds. Agrarwirtschaft und Agrarpolitik in der ehemaligen DDR im Umbruch. Berlin, 1991.

Mertes, M., S. Muller and H.A. Winkler, eds. In Search of Germany. New Brunswick, NJ, 1999.

Mestrup, H. Die SED - Ideologischer Anspruch, Herrschaftspraxis und Konflikte in Bezirk Erfurt, 1971-1989. Weimar, 2000.

Meuschel, S. Legitimation und Parteiherrschaft in der DDR, Zum Paradox von Stabilität und Revolution in der DDR. Frankfurt am Main, 1992.

— 'Uberlegungen zu einer Herrschafts- und Gesellschaftsgeschichte der DDR', Geschichte und Gesellschaft 19 (1993), pp. 5-14.

'Machtmonopol und homogenisierte Gesellschaft. Anmerkungen zu Detlef Pollack', Geschichte und Gesellschaft 26 (2000), pp. 171-83. 
Meyer, T. and T. Uttitz. 'Nachholende Marginalisierung - oder der Wandel der agrarischen Sozialstruktur in der ehemaligen DDR. Ergebnisse einer Befragung der Mitglieder einer Produktionsgenossenschaften', in Sozialer Umbruch in Ostdeutschland, ed. R. Geissler. Opladen, 1993, pp. 221-50.

Mühlberg, F. 'Eingaben als Instrument informeller Konfliktbewältigung', in Befremdlich Anders: Leben in der DDR, ed. E. Badstübner. Berlin, 2000, pp. 233-70.

Müller, K. Die Mitteldeutsche Landwirtschaft, 1945-1974: Ein Agrarsoziologisch-sozialgeographischer Beitrag zu ihrem Strukturwandel. Berlin, 1975.

Münkel, D. and J. Schwarzkopf, eds. Geschichte als Experiment. Studien in Politik, Kulture und Alltag. Frankfurt am Main, 2004.

Neckel, S. 'Das lokale Staatsorgan. Kommunale Herrschaft im Staatssozialismus der DDR', Zeitschrift für Soziologie 21(4) (1992), pp. 252-68.

Waldleben: Eine ostdeutsche Stadt im Wandel seit 1989. Frankfurt am Main, 1999.

Nehrig, C. 'Rolle, Bedeutung und Wirkungsmöglichkeiten der Blockparteien. Die DBD', in Materialien der Enquete-Kommission: 'Aufarbeitung von Geschichte und Folgen der SED-Diktatur in Deutschland', Band II/4. BadenBaden, 1995, pp. 2375-98.

'Landwirtschaftspolitik', in Die SED. Geschichte - Organisation - Politik. Ein Handbuch, eds A. Herbst, G.-R. Stephan and J. Winkler. Berlin, 1997, pp. 294-305.

'Das Leitungspersonal der VEG 1945-1970', in Eliten im Sozialismus, Beiträge zur Sozialgeschichte der DDR, ed. P. Hübner. Cologne, 1999, pp. 309-24.

'Industriearbeit im Dörflichen Milieu. Eine Studie zur Sozialgeschichte der Niederlausitzer Nebenerwerbsbauern 1945 bis 1965', in Niederlausitzer Industriearbeiter, 1935-1970: Studien zur Sozialgeschichte, ed. P. Hübner. Berlin, 1995, pp. 167-91.

— 'Das Leben auf dem Lande: Die Genossenschaften', in Leben in der DDR - Befremdlich Anders, ed. E. Badstübner. Berlin, 2000, pp. 195-218.

Niemann, H. Meinungsforschung in der DDR: Die geheimen Berichte des Instituts für Meinungsforschung an das Politbüro der SED. Cologne, 1993.

Hinterm Zaun: Politische Kultur und Meinungsforschung in der DDR - die geheimen Berichte an das Politbüro der SED. Berlin, 1995.

Niethammer, L. A. v. Plato and D. Wierling. Die volkseigene Erfahrung: Eine Archäologie des Lebens in der Industrieprovinz der DDR. 30 biographische Eröffnungen. Berlin, 1991.

Osmond, J. 'Kontinuität und Konflikt in der Landwirtschaft der SBZ/DDR zur Zeit der Bodenreform und der Vergenossenschaftlichung, 1945-1961', in Die Grenzen der Diktatur: Staat und Gesellschaft in der DDR, eds R. Bessel and R. Jessen. Göttingen, 1996, pp. 137-69.

'Geschlechtsspezifische Folgen der Bodenreform in der Sowjetischen Besatzungszone: Gutsbesitzerinnen, Bäuerinnen und Landarbeiterinnen nach 1945', in Junkerland in Bauernhand? Durchführung, Auswirkungen und Stellenwert der Bodenreform in der Sowjetischen Besatzungszone, ed. A. Bauerkämper. Stuttgart, 1996, pp. 153-68.

'From Junker Estate to Cooperative Farm: East German Agrarian Society 1945-1961', in The Workers' and Peasants' State: Communism and Society 
in East Germany under Ulbricht, 1945-1971, eds P. Major and J. Osmond. Manchester, 2002, pp. 130-50.

Palmowski, J. 'Workshop Report: Between Conformity and Eigen-Sinn. New Approaches to GDR History', German History 20(4) (2002), pp. 494-502.

Pollack, D. 'Die konstitutive Widersprüchlichkeit der DDR. Oder: War die DDR-Gesellschaft homogen?', Geschichte und Gesellschaft 24 (1998), pp. 110-31.

Pollack, P. 'Die Landwirtschaft in der DDR und nach der Wende', in Materialien der Enquetekommission: 'Überwindung der Folgen der SED Diktatur im Prozess der deutschen Einheit', Band III/2. Baden Baden, 1999, pp. 1429-99.

Polsfuss, W. 'Die Aufgaben der Kreislandwirtschaftsräte und ihrer Produktionsleitungen bei der Planung des wissenschaftlich-technischen Fortschritts in der Landwirtschaft', in Zum NÖS, eds G. Egler et al. E. Berlin, 1965.

Poutrus, P. Das Phänomen der Goldbroiler in der DDR. Cologne, 2002.

Püschel, U. Unterwegs in meinen Dörfern. Rostock, 1982.

Rauch, B. 'Der Bezirk Erfurt', in Die Ersten und die Zweiten Sekretäre der SED: Machtstrukturen und Herrschaftspraxis in den thüringischen Bezirken der DDR, eds H. Best and H. Mestrup. Weimar, 2003, pp. 31-39.

Rawert, M. Die Verschuldung der landwirtschaftlichen Produktionsgenossenschaften in der ehemaligen DDR und die Entschuldung ihrer Rechtsnachfolger. Kiel, 1994.

Reichelt, H. Blockflöte oder was? Zur Geschichte der Demokratischen Bauernpartei Deutschlands (DBD) 1948 bis 1990. Berlin, 1997.

Rempel, E. et al. (Autorenkollektiv), eds. Ökonomie der Landwirtschaft der DDR. Berlin, 1989.

Remy, D. Opposition und Verweigerung in Nordthüringen. Erfurt, 1996.

Rösler, J. Zwischen Plan und Markt: Die Wirtschaftsreform 1963-1970 in der DDR. Berlin, 1990.

'Probleme des Brigadealltags. Arbeiterverhältnisse und Arbeitsklima in volkseigenen Betrieben 1950-1989', Aus Politik und Zeitgeschichte 47(2) (1997), B 38/1997, pp. 3-17.

_ 'Das Brigadebuch: betriebliches Rapportbuch, Chronik des Brigadelebens oder Erziehungsfibel?', in Befremdlich Anders: Leben in der DDR, ed. E. Badstübner. Berlin, 2000, pp. 151-66.

'Honeckers Schachzug: Warum das Ende des NÖS in der DDR keine Proteste hervorrief', Deutschland Archiv 3 (2003), pp. 446-54.

Ross, C. Constructing Socialism at the Grassroots: The Transformation of East Germany, 1945-65. Basingstoke, 2000.

The East German Dictatorship. London, 2002.

Roß, S. 'Verhinderter Aufstieg? Frauen in lokalen Führungspositionen des DDR Staatsapparats der achtziger Jahre', in Eliten im Sozialismus: Beiträge zur Sozialgeschichte der DDR, ed. P. Hübner. Cologne, 1999, pp. 147-66.

Sakowski, H. Daniel Druskat. E. Berlin, 1976.

Scherzer, L. Der Erste. Berlin, 1997.

Schier, B. 'Alltagsleben und Agrarpolitik im 'sozialistischen Dorf'. Eine Regionalstudie zum Wandel des thüringischen Dorfes während der Jahre 194590', Aus Politik und Zeitgeschichte 47(2) (1997), B38/1997, pp. 38-47. 
Alltagsleben im 'sozialistischen' Dorf. Münster, 2001.

Schildt, A., D. Siegfried and K.-C. Lammers, eds. Dynamische Zeiten. Hamburg, 2000.

Schneider, C. Was bleibt von uns: Bauernstimmen. Bautzen, 1991.

Schöne, J. Frühling auf dem Lande? Die Kollektivierung der DDR Landwirtschaft. Berlin, 2005.

'Landwirtschaft und ländliche Gesellschaft in der DDR', in Bilanz und Perspektiven der DDR Forschung, eds R. Eppelmann, B. Faulenbach and U. Mählert. Paderborn, 2003, pp. 254-9.

Schönfelder, J. Mit Gott gegen Gülle: Die Umweltgruppe Knau/Dittersdorf 1986 bis 1981. Jena, 2000.

Schroeder, K. Geschichte und Transformation des SED-Staates. Berlin, 1994.

Schroeder, K. Der SED Staat: Partei, Staat und Gesellschaft, 1949-1990. Munich, 1998.

Schroeder, S. 'Die Ideologische Arbeit der SED zur Entwicklung der Kooperation am Ende der sechziger Jahre', Beiträge zur Geschichte der Arbeiterbewegung 22 (1980).

Schütze, W. Investitionsfinanzierung der LPG. Berlin, 1966.

Schwartz, M. 'Vetrieben in die Arbeiterschaft. "Umsiedler" als "Arbeiter" in der SBZ/DDR 1945-1952', in Arbeiter in der SBZ/DDR, eds P. Hübner and K. Tenfelde. Essen, 1999, pp. 81-128.

-Vertriebene und Umsiedlerpolitik. Munich, 2004.

Solga, H. Auf dem Weg in eine klassenlose Gesellschaft? Klassenlagen und Mobilität zwischen Generationen in der DDR. Berlin, 1995.

Sontheimer, K. and B. Wilhelm, eds. Die DDR: Politik, Gesellschaft, Wirtschaft. Hamburg, 1975.

Staritz, D. Geschichte der DDR. Frankfurt am Main, 1996.

Steiner, A. Die DDR Wirtschaftsreform der sechziger Jahre. Berlin, 1999.

_ 'Zwischen Konsumverhalten und Innovationszwang: Zum wirtschaftlichen Niedergang der DDR', in Weg in den Untergang: der innere Zerfall der DDR, eds K. Jarausch and M. Sabrow. Göttingen, 1999, pp. 153-92.

— 'Zwischen Frustration und Verschwendung', in Wunderwirtschaft: DDR Konsumkultur in den 60er Jahren, ed. I. Merkel. Cologne, 1996, pp. 30-36.

Strittmatter, E. Ole Bienkopp. E. Berlin, 1971.

Teske, R. 'Landtechnik und "Aufklärung"', Horch und Guck 41 (2003/1), pp. 12-16.

Thieme, H.-J. Die sozialistische Agrarverfassung der DDR. Stuttgart, 1969.

Thiessen, F., ed. Zwischen Plan und Pleite. Cologne, 2001.

Timmermann, H., ed. Das war die DDR, DDR-Forschung im Fadenkreuz von Herrschaft, Außenbeziehungen, Kultur und Souveränität. Münster, 2004,

Tischner, W. Katholische Kirche in der SBZ/DDR, 1945-1951. Paderborn, 2001.

Tümmler, E. Die Agrarpolitik in Mitteldeutschland. W. Berlin, 1969.

Van Hoven, B. 'Women at Work - Experiences and Identity in Rural E. Germany', Area 33(1) (2001), pp. 38-46

Vasary, I. Beyond the Plan: Social Change in a Hungarian Village. London, 1987.

Vollnhals, C. and J. Weber, eds. Der Schein der Normalität. Munich, 2002.

Wädekin, K.E. Sozialistische Agrarpolitik in Osteuropa. W. Berlin, 1974. 
Weber, A. 'Usachen und Folgen abnehmender Effizienz in der DDR Landwirtschaft', in Die Endzeit der DDR Wirtschaft, ed. E. Kurt. Opladen, 1989, pp. 225-69.

- 'Umgestaltung der Eigentumsverhältnisse und der Produktionsstruktur in der Landwirtschaft der DDR', in Materialien der Enquete-Kommission 'Aufarbeitung von Geschichte und Folgen der SED-Diktatur in Deutschland', II,4. Frankfurt am Main, 1995, pp. 2809-88.

Weber, P. Justiz und Diktatur: Thüringen, 1945-1961. Munich, 2000.

Welsh, H.A. 'Kaderpolitik auf dem Prüfstand: Die Bezirke und ihre Sekretäre, 1952-1989', in Eliten im Sozialismus: Beiträge zur Sozialgeschichte der DDR, ed. P. Hübner. Cologne, 1999, pp. 107-29.

Werkentin, F. Politische Strafjustiz in der Ara Ulbricht. Berlin, 1995.

- "Unser Land habt ihr - aber uns habt ihr noch lange nicht." Widerstand im ländlichen Milieu der SBZ/DDR', in Widerstand und Opposition in der DDR, eds K.-D. Henke, P. Steinbach and J. Tuchel. Cologne, 1999, pp. 137-48.

Wierling, D. ‘Die Jugend als innerer Feind: Konflikte in der Erziehungsdiktatur der sechziger Jahre', in Sozialgeschichte der DDR, eds H.Kaeble, J. Kocka and H. Zwahr. Stuttgart, 1994, pp. 404-25.

Wolle, S. Die heile Welt der Diktatur: Alltag und Herrschaft in der DDR, 1971-1989. Berlin, 1998.

'Herrschaft und Alltag: Die Zeitgeschichtsforschung auf der Suche nach der wahren DDR', Aus Politik und Zeitgeschichte 47(2) (1997), B 26/1997, pp. 30-38.

Wolle, S. and A. Mitter. Untergang auf Raten: Unbekannte Kapitel der DDR Geschichte. Munich, 1993.

Wollmann, H. et al., eds. Kommunaler Institutionenwandel. Opladen, 1996.

Transformation der politisch-administrativen Strukturen in Ostdeutschland. Opladen, 1997. 


\section{of Index}

ABV (Abschnittsbevollmächtigter), $x$ collectivisation campaigns, 15, 18 dealing with conflict after collectivisation, 42, 61, 100

See also police agitation brigades, 3, 13-16, 18-20, 59 agricultural councils, 86-7, 133 regional agricultural Council, 86, 159, 165 district agricultural Councils, 86, $88,95,101,105,145,156,165$ national agricultural Council, 86, 121

agricultural collective. See collective farm

Andisleben, 166, 194

Apolda (district), xxii, 5, 6, 32, 35, 36, $37,40,66,82,112,166,207,209$, 215

arable land, xxi-xxii, 21, 28-30, 39, $65,88,90,103-4,116,191$

Arnstadt (district), xxii-xxiii, 12, 20, $38,42,54,58-59,142,159,207$, autarky, xxiv, 113

authority (Herrschaft), xvii-xviii, xxix

as social praxis (Herrschaft als sozialer Praxis), xxxiv transmission of, 3, 22, 31, 38, 54-56, 66, 78, 83-85, 95, 115, 121-22, 131-33, 140, 148, 16972, 199, 224-28.

automotive industry, xxiii

Bad Langensalza (district), xxii-xxiii, $39,48,56,67,115,131,136,141$, 142, 166, 190, 209, 215

Bad Tennstedt, 5, 48, 144

Bauer, Theresia, xxvii Bauerkämper, Arndt, xxvi Beichlingen, 116, 135 Berdahl, Daphne, xxvii
Berlin Wall, xx, 22, 29, 46, 54 forced resettlements, 55 impact on SED authority 66-69, 78, 84, 156, 225

subsequent crackdown on dissent, 55-59

Berlstedt, xxv, 149-50 n.21

Bessel, Richard, xxxiii

Betriebsegoismus, xiii, 111

Betriebsparteiorganisation, 116

See also SED Party Organisations

Bezirke, xiii

Bezirksbehörde der deutschen Volkspolizei (BDVP), 41

Bezirkslandwirtschaftsrat (BLR), Bezirksleitung, SED, xiii, xxx, 14, 18, $19,21,35,36,47,67,80,84,105$, $109,112,133,135,143-46,165$, 188-90, 217

Bezirksparteiaktivtagung der SED, xiii, 103, 105

Bezirksvorstand, xiii, $x x x$

black market, 233

BLR. See Bezirkslandwirtschaftsrat BPO. See Betriebsparteiorganisation Buttstädt, 121

\section{CDU. See Christlich-Demokratische Union}

chemical industry, xxiii

chemical fertiliser, xix, 183, 195, 205

church

and attitudes of clergy towards collectivisation, 5, 7, 13, 38, 57

Catholic, xx, xxvii, 7, 13, 38, 40, $56-57,80,93$

place in rural society, 4-8, 13, 219

Protestant, xx, 7, 13

Christlich-Demokratische Union, 6, $16,35,38,46,200 \mathrm{n} 21$

class conflict, 5-11, 31-32, 40-43, $57-58,86,116$ 
collective democracy (genossenschaftliche Demokratie) definition of, xiii, practice of, $x v, x x i x, 37,47,62,88$, $122,138-45,199 \mathrm{n} 6$

collective farm (Landwirtschaftliche

Produktionsgenossenschaft or LPG)

boards of, xiii, xv, xxix, 10, 18, 23 n.17, 29, 34, 38, 57, 62, 63, 67, 83-85, 93, 108, 111-17, 122, $135,141-44,157,188$ commissions of, xiii, 29, 88, 122 early collective farms 4 inviolability of, 137-40, 168-84 members' assemblies of, xiii, $\mathrm{xv}$, $28,31-62,84,92,110,114,122$, 142, 148n1, 159, 167, 188, 208 mergers of, $85,88,89-90,94,101-5$, $113-5,136,166-70,189$

types of, 4, 27-31 withdrawal of membership from, 44-45, 61-62, 146, 193

collective farmers change in relationship to land, 167 , $179,184,187-88,199,214$

Class of the, 86, 138-142 pay and conditions, 60-61, 120, 146, 158-62, 167-68, 185-86, 217

qualifications in socialist agriculture, xxvii, 13, 15, 7779, 84-85, 98n24, 108, 122-24, 129n64, 156-57, 226-27.

collective livestock holdings, 10, 30, $32,47,88-94,114$

collective property, 121, 138

collectivisation campaigns

before the 'Socialist Spring', 13-18

early years, 3-9

focus on women, 15

Socialist Spring, 18-22

Stasi activity, 20

suicide, 19

threat of arrest,19-20

commuters, xxii-xxiii, 196

Construction of Socialism (Aufbau des Sozialismus), 4 consumer socialism, xix, xxvii, 15558, 195-97

cooperation between collective farms

(Kooperation)

arguments against, 114-15

comparison with collectivisation, 136, 169

early forms, 101-4

fears of collective farmers, 104-15, 119-21, 133-37

cooperative community

(Kooperationsgemeinschaft or KOG), 103, 109-17, 135-46,

165-71, 181-93

cooperative council (Kooperationsrat or KOR), xiv absence of, 106, breakdown of, 141-47, 191-94 reestablishment of, 211-12 cooperative crop production unit (Kooperative Abteilung Pflanzenproduktion or KAP), 140-43, 166-72, 179-82 cooperative union

(Kooperationsverband or KOV), 134,137

DBD. See Demokratische

Bauernpartei Deutschlands

Delikat, xiii

Demokratische Bauernpartei

Deutschlands, xxvii, xxx-xxxii,

$6,16,79,110,117-18,141-46$,

$170-71,212,219$

Demokratischer Frauenbund

Deutschlands, 16

denazification measures, $x x i, 57$

Deutscher Turn- und Sportbund, 16

DFD. See Demokratischer

Frauenbund Deutschlands

Diedorf, 9

DTSB. See Deutscher Turn- und

Sportbund

Eckhart, Gabrielle, xxv

Eckolstädt, 5

economic sabotage, 5, 43, 55-58, 165, 
Eichsfeld, xx, xxvii, 13, 40, 56

Eigen-Sinn, xxxiv

Eingaben der Bevölkerung, xiii, xxxxxxi, 165, 169, 189, 191, 207-9

Eisenach (district), xx, xxii, 27, 37, 42, 43, 114, 166, 213, 215, 216

Enterprise Egotism

(Betriebsegoismus), xiii, 111

Erfurt (region), $x x-x x$ iii

Erfurt-Land (district), xxii, 33, 39-40, $46,93,102-3,106,111,115,141$, 166, 169, 190, 193-94, 207, 217

Essleben, 143, 178

Farmers' Mutual Aid Union (Verein der gegenseitigen Bauernhilfe or VdgB), 7, 12, 16, 40, 79, 83

FDGB (Freier Deutscher Gewerkschaftsbund), 16

FDJ (Freie Deutsche Jugend), 16

Federal Republic of Germany (Bundesrepublik Deutschland or BRD). See West Germany

feed crops, 146

distribution to livestock farms, 112, 147, 164, 180-87, 191-95, 211-12

maize as a, 16, 64-65

shortage of, 58, 146, 160, 182, 1902, 210-211, 215

Felfe, Werner, 49n6, 204

field sizes, 213

flight to the west, 5, 14, 22, 31, 39-43, 47,55

food supply, 5, 11, 22, 39, 137, 197, 207, 210

food industries, 133-39

Freie Spitzen, 6

Friedrichsrode, 209

fuel supply, 132, 183-89, 213, 228

Gamstädt, 67, 217

GDR

collapse of, 219

founding of, 3

uncertainty over the future of, 34

Gebesee, 111
Genossenschaftliche Demokratie definition of, xiii,

practice of, $x v$, xxix, 37, 47, 62, 88, 122, 138-145, 199n6

German Farmers' Congress

(Deutsches Bauernkongress)

VII German Farmers' Congress, 63

VIII German Farmers' Congress, 115

X German Farmers' Congress, 133, 136

XII German Farmers' Congress, 211

German Farmers' Party. See

Demokratische Bauernpartei

Deutschlands (DBD)

Gierstädt, 44

gigantism, 204

Gotha (district), xxii, 6, 15, 39, 40, 46, $62,67,90,92,162,215$

Grandetzka, Willy, 171

Groß-LPG

action against, 136, 172

arguments against, 112-3, 124n2, 166

arguments for, $112,143-47$

establishment of, 102

Großbauern (wealthy farmers), xiii policies against, 5, 8

restrictions on individual wealth, 31-33

Grossbrembach, 135, 168

Grossengottern, 171

Grossheringen, 209

Grossrudestedt, 166, 167

Gruhle, Jürgen, xxvii

Grüneberg, Gerhard, 13, 138, 139, 163-64, 184-85, 190-91, 204

harvest helpers, 39, 67

harvest machinery, 102, 112, 117, 135, 143,184

Heiligenstadt (district), xx, xxii, 9, 13, $32,34,37,38,55,59,60,62,67$,

$80,84,142,161,215$

Henningsleben, 68

Herbsleben, 67

Heringen, 57, 111 
Hermstedt, 187

Honecker, Erich, xxxi, 155, 157-172, 183, 185

housing, xxiv, 157-8, 196-7

Humm, Antonia-Maria, xxviii

Ilfeld, 37

Immenrode, 209

individual plots (individuelle Hauswirtschaften), 22, 30, 45-6, 58, 94, 123, 181, 188, 197, 218

industry

price policies and supply to agriculture, 121, 162-63, 183$89,195,217-19$

integrated deployment of machinery (Komplexeinsatz), xiii, 106, 108, 112

Isserode, 216

Jessen, Ralph, xxxiii

Jugendweihe, 7

June 1953

demonstrations, 5-8

symbolism of, 39, 44, 183

Jützenbach, 207, 220

Kalteneber, 142

KAP. See Kooperative Abteilung Pflanzenproduktion

Kerspleben, 166

Kindelbrück, 10, 18-19, 43, 60

Kipping, Manfred, xxviii

Kleinbauern (small farm holder), xiii, 33

Kleinneuhausen, 135

Klose, Heinrich, xxviii

Kluge, Ulrich, xxvi

KOG. See Kooperationsgemeinschaft

Konsum, xiii, 209

Kooperation

arguments against, 114-15

comparison with collectivisation, 136,169

early forms, 101-4

fears of collective farmers, 104-15, 119-21, 133-37
Kooperationsgemeinschaft (KOG),

103, 109-17, 135-46, 165-71, 181-93

Kooperationsrat (KOR), xiv absence of, 106

breakdown of, 141-47, 191-94

reestablishment of, 211-12

Kooperationsverband (KOV), 134, 137

Kooperative Abteilung Pflanzenproduktion (KAP), 140-43, 166-72, 179-82

KOR. See Kooperationsrat

KOV. See Kooperationsverband

KPKK. See

Kreisparteikontrollkomission

Krambach, Kurt, xxiv

Kreise (districts), $x x$

Kreisleitungen der SED, 16, 19, 20, $35,37,40,81-84,90,94,107,109$, 116-17, 136-46, 162-70, 208

Kreisparteikontrollkomission der SED (KPKK), 10, 56-58, 80-81

land reform, xiv, xxi, xxiv, xxvi

Landwirtschaftliche

Produktionsgenossenschaft (LPG)

boards of, xiii, xv, xxix, 10, 18, 23 n.17, 29, 34, 38, 57, 62, 63, 67, 83-85, 93, 108, 111-17, 122, 135, 141-44, 157, 188.

commissions of, xiii, 29, 88, 122 early collective farms, 4 inviolability of, 137-40, 168-84 members' assemblies of, xiii, $\mathrm{xv}$, 28, 31-62, 84, 92, 110, 114, 122, 142, 148 n.1, 159, 167, 188, 208 mergers of, 85, 88, 89-90, 94, 101-5, $113-5,136,166-70,189$

types of, 4, 27-31

withdrawal of membership from, 44-45, 61-62, 146, 193

Langenhahn, Dagmar, xxvii, xxviii LDPD. See Liberal-Demokratische Partei Deutschlands

Leubingen, 165 
Liberal-Demokratische Partei

Deutschlands, 6

Lindenberger, Thomas, xxvii, xxxiv

livestock

intensive farming of, 93, 102, 182-86

diseases of, 57, 160, 183, 210

mortality rate of, 42-43, 57, 160, 192, 215

living standards

differentiation between rural communities, 196, 205

comparison of urban and rural, 157-60

policy of converging (Annäherung), xxiv, 195, 208

LPG. See Landwirtschaftliche Produktionsgenossenschaft

LPG-Aktiv, xiv, 80

LPG chairmen

and implementation of agricultural policy, xiv, xv, 62-3, 78, 81-6, 92-5, 105-48, 161

relationship with KAP leaders, 168-84

dealing with economic decline, 188-94, 216

resignations of, 13,60

LPG members. See collective farmers.

LPG functionaries

capacity to implement SED policy, $78,108-110$

reliability of, 116

resignations, 33-34, 57, 108

training, 83-84

See also LPG chairmen, LPG work brigade leaders

LPG Pflanzenproduktion (LPG P)

evolution of, 187-98

formation of, 181

relationship with LPG T, 190-98, 211-19

LPG Tierproduktion (LPG T)

formation of, 181-86

mergers of, 189

LPG work brigade leaders, xiv, 29, $66,83,116,137,157,167$

Lüdtke, Alf, xxxviii
Maschinen-Traktoren-Stationen

(MTS), 7-11, 18, 31, 36-39, 66,

83-84, 87

maize. See feed crops

Mannstedt, 135

manpower requirements in agriculture, xxiii, 29, 30, 32, 45, $159,184,189,212,216-17$

MTS. See Maschinen-TraktorenStationen

mayors

and collectivisation campaigns, 6-7, 15-21

response to SED agricultural policy, 35-40, 46, 61, 65, 67

Merxleben, xxvii, 23n7

military service, 158

mining, xxiii

model statutes

changing attitudes to, 48

failure to adhere to, 38, 46

for Type I LPGs, 28

for Type II LPGs, 29

for Type III LPGs, 29-30

Mückenberger, Erich 13

Mühlhausen (district), xxii, 3, 5, 6, 17, $33,34,39,57,60,61,62,67,94$, $102,103,131,142$

Nationale Volksarmee, 39

National Socialism symbols of, 55

Nebenerwerbsbauer (part-time farmer), xiv, xxiii, 16

Nehrig, Christel, xxvii, xxviii

Neubauer (new farmer), xxi, xiv, 7

Neue Deutsche Bauernzeitung, 211

Neues Ökonomisches System der Planung und Leitung (NÖS), 85-96, 107-8

Neuholland, 118

Neumark, 214

New Course, 5

New Economic System, 85-96, 107-8

Niederroslar, 209

Niedersachswerfen, 37

Niederzimmern, xxviii, 62 
NÖS. See Neues Ökonomisches System der Planung und Leitung Nordhausen (district), xxii, xxiii, 20, $34,36,37,62,64,94,102,103$, $111,171,215$

NVA. See Nationale Volksarmee

Oberdorla, 5

Oberreissen, 123

Oberwiera, xxviii

Offenstall, xiv, 64-65

office machinery industry, xxiii

oil crises, xix, 185-86

Olbersleben, 143

Ole Bienkopp, 64-65

Ortsbauernführer, xiv

Ossmanstedt, 143

pasture land, xxii, 65, 93, 191-92

police (Deutsche Volkspolizei)

role in collectivisation campaigns, $6,7,15,19-21$

fighting crime after collectivisation, $39,42-43,57-67$

Pollack, Detlef, xxxiii

popular opinion sources for, $x x x i$

Potsdam (Bezirk), xxv

Poutrus, Patrice, xxvii

production quotas, 5, 6, 9, 11, 16, 17, 57

Püschel, Ursula, xxv

Rat des Bezirkes (Regional State Administration), xxx, 65, 159, 185, 194, 207, 217, 219

Rat des Kreises (District State Administration), 16, 29, 35, 36, $37,43,48,60,62,66,67,114,140$, $141,178,191,209,227$

Rat für Landwirtschaft und

Nahrungsguterwirtschaft (Kreis), 134-36, 141-47, 161, 165-69

See also agricultural councils

Rat für Landwirtschaft und

Nahrungsguterwirtschaft (Bezirk), 134-36, 160, 165-66
See also agricultural councils refugees (Umsiedler), xv, xxi, 31

Reichenbach, 56

reunification

hope for, 7, 46

RLN (K). See Rat für Landwirtschaft und Nahrungsguterwirtschaft (Kreis),

RLN (B). See Rat für Landwirtschaft und Nahrungsguterwirtschaft (Bezirk)

Ross, Sabine, xxvii

Schellenburg, 135

Schier, Barbara, xxvii

Schöne, Jens, xxvii

Schürer, Gerhard, 184-85

SED Bezirksleitung (Regional SED Administration), xiii, xxx, 14, 18, $19,21,35,36,47,67,80,84,105$, $109,112,133,135,143-46,165$, 188-90, 217

SED Central Committee, 8, 13, 18, 40, $56,118,122,137$

impact of 10 th plenary session $1969,140-48$

SED Kreisleitungen (District SED Administrations), 16, 19, 20, 35, 37, 40, 81-84, 90, 94, 107, 109, 116-117, 136-146, 162-170, 208

SED Party Congresses (Parteitag)

II SED Party Congress, 4, V SED Party Congress, 8 VII SED Party Congress, 132, 136, 141, 159

VIII SED Party Congress, 123, 147, 163-67, 181, 185, 196, 227

IX SED Party Congress, 187

X SED Party Congress, 198-99, 204, 211

SED Party Organisations, xiv, 8, 12, 68, 69, 77-94, 110-17, 178, 199, 227

SED Party Secretaries, xiv, 6, 10, 12, 40, 81-82, 115-16, 131

SED penetration of rural communities, 4-7, 68, 78-79, 107, 115-119, 144-45 
shopping, 208-209

shortage economy, xix, 146, 189, 198, 206, 216

Sozialistische Einheitspartei

Deutschlands. See SED

socialist aid, 110

socialist competition (Sozialistischer Wettbewerb), 88-93, 134, 226

soil exhaustion, 213

Sömmerda (district), xxii, 10, 18, 21, 37, 43, 60, 81-82, 90-92, 101, 116$17,123,133-36,139-148,159$, 162, 166-67, 196, 205, 208, 215

Sondershausen (district), xxii, 37, 40, 43, 45, 58, 63, 80, 161, 166, 209

Sonnendorf, 209

Soviet agriculture, 4, 16, 17, 65, 112 Soviet Zone of Occupation, 4, xv, xxii, xxiv, 7

socialist business economics (Sozialistische Betriebswirtschaft), xv, 92-93, 118-20, 140

Stasi, xxx-xxxi, 9, 12, 20-21, 23n17, $56,58,61,104$ unofficial staff (Inoffizielle

Mitarbeiter or IM), 214-16

State Planning Commission, xxxi, 11, 184,210

State security. See Stasi

Steinrode, 142

Straussfurt, 135

Strittmatter, Erwin, 64

textiles industry, xxiii

Thuringia, $x x-x x i, x x v i i i$

Thuringian Forests, xxii

Tieftal, 46

Torba, 45

totalitarianism, xxxii

Töttelstadt, 193

Trebra, 107

troubleshooting brigades, 35-37, 62

Tunzenhausen, 135
Ulbricht, Walter, xxxi

Urbach, 111

Uthleben, 187

VdgB (Verein der gegenseitigen Bauernhilfe), 7, 12, 16, 40, 79, 83

Vogelsberg, 168

Volkspolizei

role in collectivisation campaigns, $6,7,15,19-21$

fighting crime after collectivisation, $39,42-43,57-67$

Volkssolidarität, 16

Walschleben, 111, 193

Wandersleben, 16

water supply, 156, 205-8

Wehrmacht, xv, 56

Weimar (district), xxii,xxiii, 15, 19, 32, 58, 62-63, 67, 91, 102, 119, 144, $146,214-16$

Weissensee, 135

Werningshausen, 143

West Germany border with, $x x, 14,54-56$

comparison with East Germany, $x x, 11,16,220$

Witterda, 46

Women

changing working conditions for, xxii, xxvii, 15, 33, 119, 157-60

Worbis (district), xx, xxii, xxviii, 13, $34,38,45,63,80,94,109,110$, $142,146,166,200 \mathrm{n} 20,203,206$, 215

Workers' and Farmers' Inspectorate, 192

work brigades

territorial, 117, 168, 214

task-based, 171, 179, 214

work norms, 5, 47, 49 n.5, 90-92, 169

work unit (Arbeitseinheit), 38, 48, 49n5, 58-61, 70n23, 90, 92, 144, 168-69 